
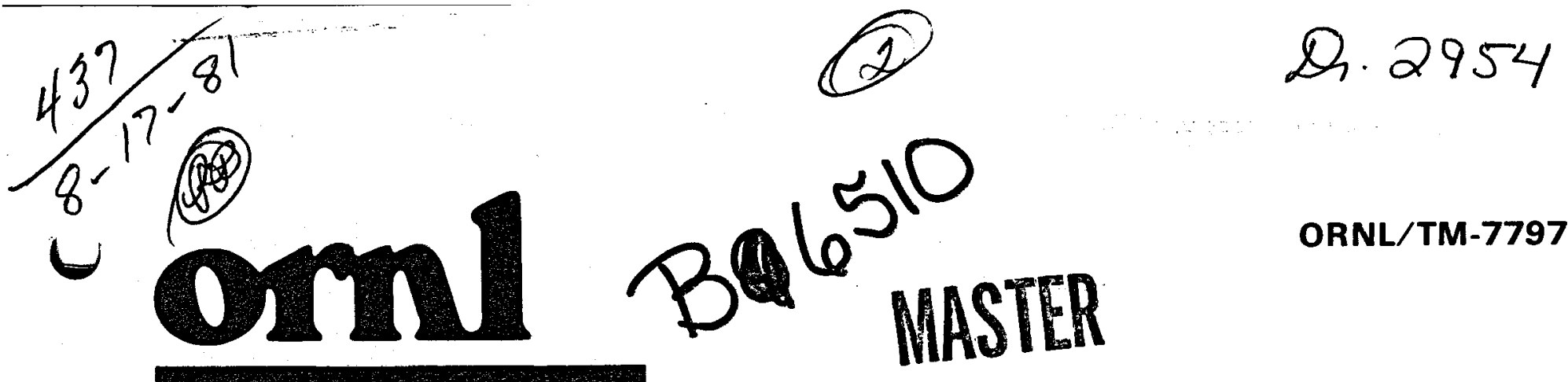

ORNL/TM-7797

OAK

RIDGE

NATIONAL

LABORATORY

UNION

CARBIDE
Condensation of Refrigerant-11 on the Outside of Vertical

\section{Enhanced Tubes}

\author{
N. Domingo
}

OPERATED BY

UNION CARBIDE CORPORATION FOR THE UNITED STATES DEPARTMENT OF ENERGY 


\section{Printed in the United States of America. Available from National Technical Information Service \\ U.S. Department of Commerce \\ 5285 Port Royal Road, Springfield, Virginia 22161}

NTIS price codes-Printed Copy: A05 Microfiche A01

This report was prepared as an account of work sponsored by an agency of the United States Government. Neither the United States Government nor any agency thereof, nor any of their employees, makes any warranty, express or implied, or assumes any legal liability or responsibility for the accuracy, completeness, or usefulness of any information, apparatus, product, or process disclosed, or represents that its use would not infringe privately owned rights. Reference herein to any specific commercial product, process, or service by trade name, trademark, manufacturer, or otherwise, does not necessarily constitute or imply its endorsement, recommendation, or favoring by the United States Government or any agency thereot. The views and opinions of authors expressed herein do not necessarily state or reflect those of the United States Government or any agency thereof. 
Contract No. W-7405-eng-26

Engineering Technology Division

\section{CONDENSATION OF REFRIGERANT-11 ON THE OUTSIDE OF VERTICAL ENTHANCED TUBES}

N. Domingo

Date Published: August 1981

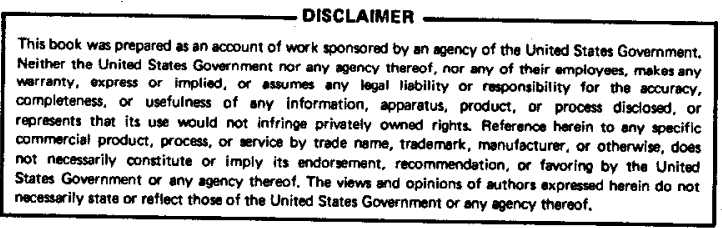

Prepared by the OAR RIDGE NATIONAC LABORATORY OAR RIDGE, TENNESSEE 37830 operated by UNION CARBIDE CORPORATION

for the DEPARTMENT OF ENERGY 


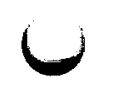


LIST OF FIGURES

LIST OF TABLES

vif

LIST OF SYMBOLS

1x

ACKNOWLEDGMENTS

$x 1$

ABSTRACT

1. INTRODUCTION $\ldots \ldots \ldots \ldots \ldots \ldots \ldots \ldots \ldots \ldots \ldots \ldots \ldots \ldots \ldots \ldots \ldots \ldots \ldots . \ldots \ldots$

2. DESCRIPTION OF EQUIPHENT $\ldots \ldots \ldots \ldots \ldots \ldots \ldots \ldots \ldots \ldots \ldots \ldots \ldots \ldots$

2.1 General Flow Description ........................ 6

2.2 Condenser Tube and Installation $\ldots \ldots \ldots \ldots \ldots \ldots \ldots \ldots \ldots$ 7

2.3 Test Tubes $\ldots \ldots \ldots \ldots \ldots \ldots \ldots \ldots \ldots \ldots \ldots \ldots \ldots \ldots \ldots \ldots \ldots \ldots \ldots . \ldots \ldots$ 8

3. PROCEDURES AND INSTRUMENTATION $\ldots \ldots \ldots \ldots \ldots \ldots \ldots \ldots \ldots \ldots \ldots \ldots \ldots$

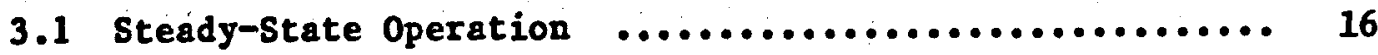

3.2 Instrumentation ............................ 17

4. ANALISIS ...................................... 19

4.1 Overall Condensing Coefficients .................... 19

4.2 Individual Heat Transfer Coefficients .............. 20

4.3 Evaluation of Water-Side Coefficients by the Wilson-Plot Method ............................. 21

5. RESULTS AND DISCUSSION $\ldots \ldots \ldots \ldots \ldots \ldots \ldots \ldots \ldots \ldots \ldots \ldots \ldots \ldots \ldots . \ldots \ldots$

5.1 Enhanced Tube Results ......................... 28

5.2 Double Fluted Tube Results ..................... 34

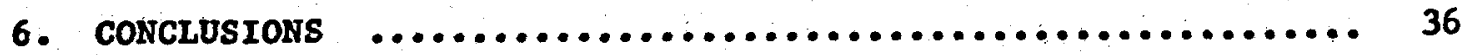

REFERENCES $\quad \ldots \ldots \ldots \ldots \ldots \ldots \ldots \ldots \ldots \ldots \ldots \ldots \ldots \ldots \ldots \ldots \ldots \ldots \ldots \ldots \ldots \ldots . \ldots \ldots$

APPENDIX A. SAMPLES OF DATA REDUCTION .................. 39

A.1 Physical Properties for $\mathrm{R}-11$................... 39

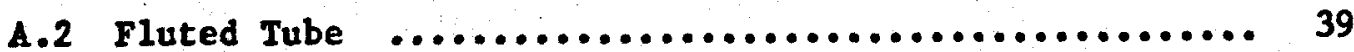

APPENDIX B. WILSON-PLOT RESULTS $\ldots \ldots \ldots \ldots \ldots \ldots \ldots \ldots \ldots \ldots \ldots \ldots . . \ldots 9$

ÁPPENDIX C. EXPERIMENTAL DATA ....................... 63

APPENDIX D. SI CONVERSION FACTORS .................... 79 
$\cup$ 
2.1 Schematic diagram of experimental apparatus ............... 4

2.2 Overall view of test facllity ......................... 5

2.3 Detalls of condenser test section ...................... 8

2.4 Photograph of a sample test tube with a neoprene skirt attached at midpoint of condensing length ............. 9

2.5 Photographs of tube samples - Tubes $A, L$, and $L^{*} \ldots \ldots \ldots \ldots \ldots 11$

2.6 Photographs of tube samples - Tubes $M$ and $N$............... 12

2.7 Photographs of tube samples - Tubes $0, R$, and $S \ldots \ldots \ldots \ldots . .13$

2.8 Photographs of tube samples - Tubes $T$ and $U \ldots \ldots \ldots \ldots \ldots \ldots \ldots 14$

5.1 Wilson-plot results for fluted tubes on a composite heat transfer coefficlent vs heat flux basis ............... 23

5.2 Wilson-plot results for Tubes $M, N, 0, R$, and $S$ on a composite heat transfer coefficient vs heat flux basts .......................................... 24

5.3 Wilson-plot results for Tube $L$ and duplicate tubes (containing equally spaced drainage skirts) on a composite heat transfer coefficlent vs heat flux basis ....... 24

5.4 Wilson-plot results for fluted tubes on a heat load vs composite temperature difference basis

5.5 Wilson-plot results for Tubes $M, N, 0, R$, and $S$ on a heat load vs composite temperature difference. basts ............................................. 25

5.6 W11son-plot results for Tube $L$ and duplicate tubes (containing equally spaced dralnage skirts) on a heat load vs composite temperature difference basis ............ 26

5.7 Overall heat transfer performance of Tubes $L$ and $L^{*}$ with water flowing through an annulus at $1.4 \times 10^{-3}$ $\mathrm{m}^{3} / \mathrm{s}(22 \mathrm{gpm}) \ldots \ldots \ldots \ldots \ldots \ldots \ldots \ldots \ldots \ldots \ldots \ldots \ldots \ldots \ldots \ldots \ldots \ldots \ldots . \ldots . \ldots \ldots$

5.8 Overall heat transfer performance of Tubes $L$ and $I^{*}$ with water flowing through an annulus at $4.8 \times 10^{-4}$ $\mathrm{m}^{3} / \mathrm{s}(7.6 \mathrm{gpm})$

5.9 Overall heat transfer performance of Tubes $L$ and $L^{*}$ with water flowing through an annulus at $1.9 \times 10^{-4}$ $\mathrm{m}^{3} / \mathrm{s}(3.0 \mathrm{gpm})$

A.1 Wilson plot for $R-11$ condensing outs 1 de fluted

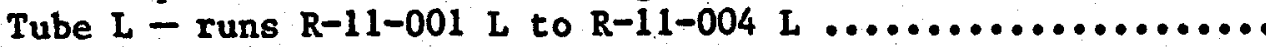


vi

ن

$\because$

$=$

3

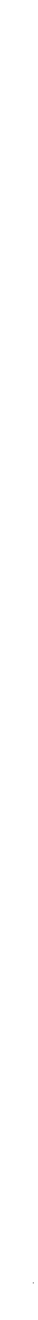


2.1 Characteristics of tubes $\ldots \ldots \ldots \ldots \ldots \ldots \ldots \ldots \ldots \ldots \ldots \ldots \ldots \ldots$

A.1 Sample of experimental data $-R-11$

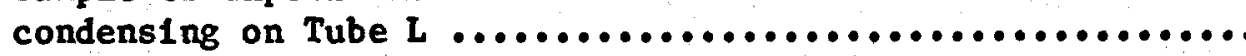

A.2 Sample information for the Wilson plot $\mathrm{R}-11$ condensing on Tube $\mathrm{L}$

B.1 Summary of experimental conditions and results

from Wilson plots for $R-11$ condensing on vertical

Tube A .........................................

B.2 Summary of experimental conditions and results from Wilson plots for $R-11$ condensing on vertical

Tube $A-1$......................................

B.3 Summary of experimental conditions and results from Wilson plots for $R-11$ condensing on vertical

Tube $\mathrm{L}$

B.4 Summary of experimental conditions and results from Wilson plots for $R-11$ condensing on vertical

Tube $1-1$.......................................

B.5 Summary of experimental conditions and results from Wilson plots for $R-11$ condensing on vertical

B.6 Summary of experimental conditions and results from Wilson plots for $R-11$ condensing of vertical

Tube $M$.........................................

B.7 Summary of experimental conditions and results from wilson plots for $R-11$ condensing on vertical

Tube $N$.........................................

B.8 Summary of experimental conditions and results from Wilson plots for $R-11$ condensing on vertical Tube 0 (no rod on water side) .........................

B.9 Summary of experimental conditions and results from Wilson plots for $R-11$ condensing on vertical

Tube R ........................................

B.10 Summary of experimental conditions and results from W1lson plots for $R-11$ condensing on vertical Tube $s$.......................................

B.11 Summary of experimental conditions and results from Wilson plots for $R-11$ condensing on vertical Tube $\mathrm{T}$......................................... 
B.12 Summary of experimental conditions and results from Wilson plots for $R-11$ condensing on vertical Tube $\mathrm{U}$

C.1 Experimental data for $\mathrm{R}-11$ condensing on Tube A ......................................... 64

C.2 Experimental data for R-11 condensing on Tube $A-1$..................................... 65

C.3 Experimental data for $R-11$ condensing on Tube $L$. .......................................666

C.4 Experimental data for $\mathrm{R}-11$ condensing on Tube $L-1$. ....................................68

C.5 Experimental data for $\mathrm{R}-11$ condensing on Tube $L-3$. .................................... 69

C.6 Experimental data for $\mathrm{R}-11$ condensing on Tube $L^{*} \ldots \ldots \ldots \ldots \ldots \ldots \ldots \ldots \ldots \ldots \ldots \ldots \ldots \ldots \ldots \ldots \ldots \ldots \ldots \ldots . . \ldots 70$

C.7 Experimental data for $R-11$ condensing on Tube $\mathrm{M}$........................................ 71

C.8 Experimental data for $R-11$ condensing on Tube $N$....................................... 72

C.9 Experimental data for $R-11$ condensing on Tube 0 (no rod on water side) ...................... 73

C.10 Experimental data for $R-11$ condensing on Tube $R$...................................... 75

C.11 Experimental data for $\mathrm{R}-11$ condensing on Tube $S$...................................... 76

C.12 Experimental data for $\mathrm{R}-11$ condensing on Tube $T$...................................... 77

C.13 Experimental data for $\mathrm{R}-11$ condensing on Tube $\mathrm{U}$ 


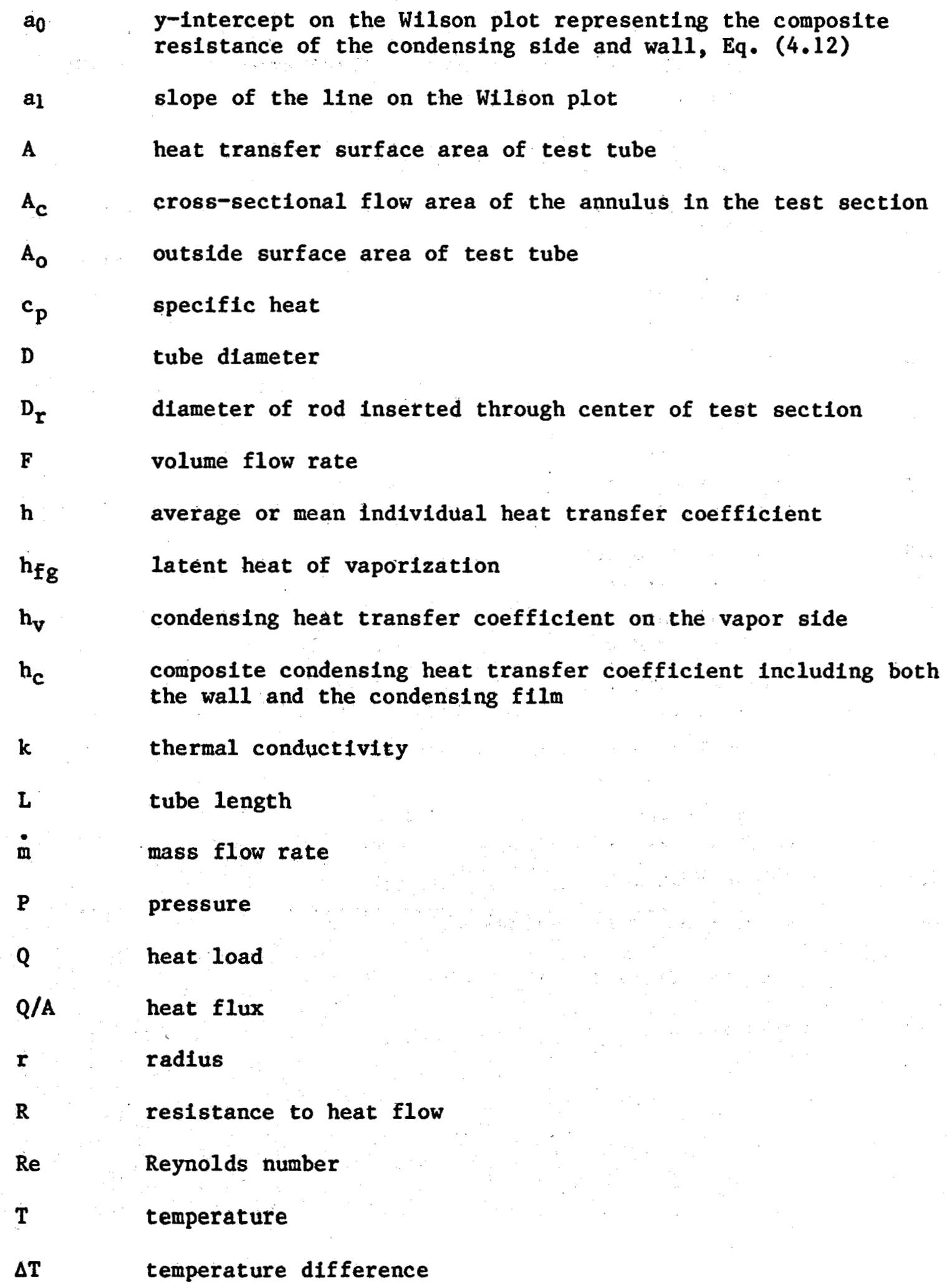


$\overline{\Delta T} \quad$ mean temperature difference between the condensing vapor and coolant

$\Delta \mathrm{T}_{\mathrm{c}} \quad$ composite temperature difference including both condensing film and wall

U overall condensing heat transfer coefficient

v water velocity

Greek Symbols

$\Delta \quad$ finite difference

mass density

Subscripts

avg average

c condensate

f1 Inside fouling

fo outside fouling

1 inside

in inlet

o outside

out outlet

sat saturation

v vapor; vapor (condensing) side

w water; water side

wall wal1; surface 


\section{ACRNOWLEDGMENTS}

This investigation was performed at the Oak Ridge National Laboratory (ORNL) operated by the Union Carbide Corporation for the Department of Energy (DOE). This study was part of the general program on low-temperature heat utilization being performed by ORNL for the DOE Division of Geothermal Energy.

The author appreciates the assistance of many ORNL staff members. The author is particularly grateful for the contributions of the following people: H. W. Hoffman, Section Head, J. W. Michel, Program Manager, R. W. Murphy, Project Engineer, and R. N. Lyon, ORNL Consu1tant, for their helpful suggestions throughout the program; C. V. Hardin, Engineer Technologist, for operation of the test equipment and collection of the data; R. L. Linkous, Project Technician, for his assistance in organizing some of the data for the report; and the members of the Engineering Technology Division Publications office and Word Processing Center for assistance in organizing the material and typing the manuscript. 


\title{
CONDENSATION OF REFRIGERANT-11 ON THE OUTSIDE OF VERTICAL ENHANCED TUBES
}

\author{
N. Domingo
}

\begin{abstract}
Experiments were conducted to determine heat transfer performance of single vertical tubes with Refrigerant-11 condensing on its outside surface. Twelve enhanced (fluted, spiraled, roped, and corrugated) tubes of $2.54-\mathrm{cm}$ (1-in.) nominal outside diameter and $1.2-\mathrm{m}$ (4-ft) length were tested. Several of the tested tubes featured internal enhanced geometries. A previously tested smooth tube served as the basis for comparison.

Composite heat transfer coefficients (coefficients that include the resistances of both the condensing film and the tube wa11), based on the total tube outside surface area, ranged from 850 to $6,530 \mathrm{~W} / \mathrm{m}^{2} \cdot \mathrm{R}\left(150\right.$ to $\left.1,150 \mathrm{Btu} / \mathrm{h} \cdot \mathrm{ft}^{2} \cdot{ }^{\circ} \mathrm{F}\right)$ over the heat flux range of 5,675 to $31,375 \mathrm{~W} / \mathrm{m}^{2}(1,800$ to $\left.9,950 \mathrm{Btu} / \mathrm{h} \cdot \mathrm{ft}^{2}\right)$. The primary conclusions from this study are: (1) for a given heat $f l u x$, an external fluted tube can increase composite condensing heat transfer coefficients by up to 5.5 times the smooth tube values, giving better condensing performance than any of the other geometries tested; (2) further increase in composite condensing coefficients can be achieved by using skirts to divide the fluted tube into equal condensing lengths; and (3) for a given overall temperature difference and water flow rate, internal flutes can increase the overall performance by up to $17 \%$ over that for a tube with identical outside flutes and a smooth inside surface.
\end{abstract}

\section{INTRODUCTION}

Fundamental to all heat power systems is the condition that a portion of the heat supplied to the cycle must be rejected. In a geothermal power plant, using a Rankine cycle, where the relatively low temperature heat source inherently yields a low thermal efficiency, the amount of heat rejected per kilowatt-hour of output is three to six times greater than that of a fossil- or nuclear-fueled power plant.'

This condition is further complicated in geothermal power cycles using a secondary working fluid, typically a fluorocarbon or hydrocarbon. In these binary cycles, the temperature of heat addition from 
the geothermal fluid to the secondary working fluid tends to be lower, thereby increasing the amount of heat rejected per kilowat-hour of output. The waste heat is also more difficult to reject, because the condensing film coefficients for these secondary working fluids are quite low. Therefore, in an energy conversion system using such secondary fluids, the heat exchangers would be relatively large and would constitute a major part of the total system capital costs.

Improvements in heat exchanger thermal performance can result in substantial cost reductions and will favorably affect the overall feasibility of developing the geothermal resource. One method for improving the condensing heat transfer characteristics of heat exchangers is through the use of enhanced surfaces to increase heat transfer coefficients. Achieving higher condensing coefficients is significant to heat exchanger design, because the condensing film resistance can be dominant in a conventional smooth tube heat exchanger utilizing fluorocarbons or hydrocarbons.

Earlier studies ${ }^{2,3}$ at Oak Ridge National Laboratory (ORNL) investigated the performance of vertical tubes with enhanced outside surfaces on which various fluorocarbons, amonia, and isobutane were condensed. With fluorocarbons or isobutane as the working fluid, condensing heat transfer coefficients improved by factors up to 6 to 7 times that of a smooth tube, depending on the fluid properties, tube geometries, and heat flux. These experiments and field data produced the design parameters from which prototype condensers for geothermal applications have been built and tested. 4,5

Like earlier ORNL studies, this report presents experimental data for Refrigerant-11 ( $R-11$ ) (trichlorofluoromethane) condensing on a variety of vertical enhanced tubes. This study includes data on the effect of condensing length on heat transfer performance and overall heat transfer data for a double fluted tube. The choice of $R-11$ as the working medium was based on its advantageous low boiling point and safetyrelated, nonflamable characteristics. Earlier studies ${ }^{3}$ had also shown $R-11$ and isobutane $(R-600 a)$ give similar heat transfer performance for a given tube and heat load. 
Background material for this study was given in a previous report, 3 with detailed descriptions of the equipment, procedures, and instrumentation, all of which remained the same throughout this study. Therefore, only brief descriptions of these items are provided in this report. 


\section{DESCRIPTION OF EQUIPMENT}

The equipment used in this investigation is shown schematically in Fig. 2.1 and is presented in an overall view in Fig. 2.2. The system (designed for a maximum heat load of $5 \mathrm{~kW}$ ) consisted of three circuits: working fluid, primary cooling, and secondary loops. The working fluid loop was designed for fluorocarbons with the maximum operating pressure and temperature set at $1.65 \times 10^{6} \mathrm{~Pa}(240 \mathrm{psia})$ and $339 \mathrm{~K}\left(150^{\circ} \mathrm{F}\right)$. In this study, R-11 was used as the working fluid.

The test section was a single tube vertical condenser made of stainless steel and was built to accommodate tubes of $2.54-\mathrm{cm}(1-$ in.) nominal diameter and 1.2-m (4-ft) length. The system was manually controlled, and the heat load was set by the power output to the boiler. View ports on the condenser module permitted visual observation of the tube's condensing surface, with the aid of a light at suitable locations,

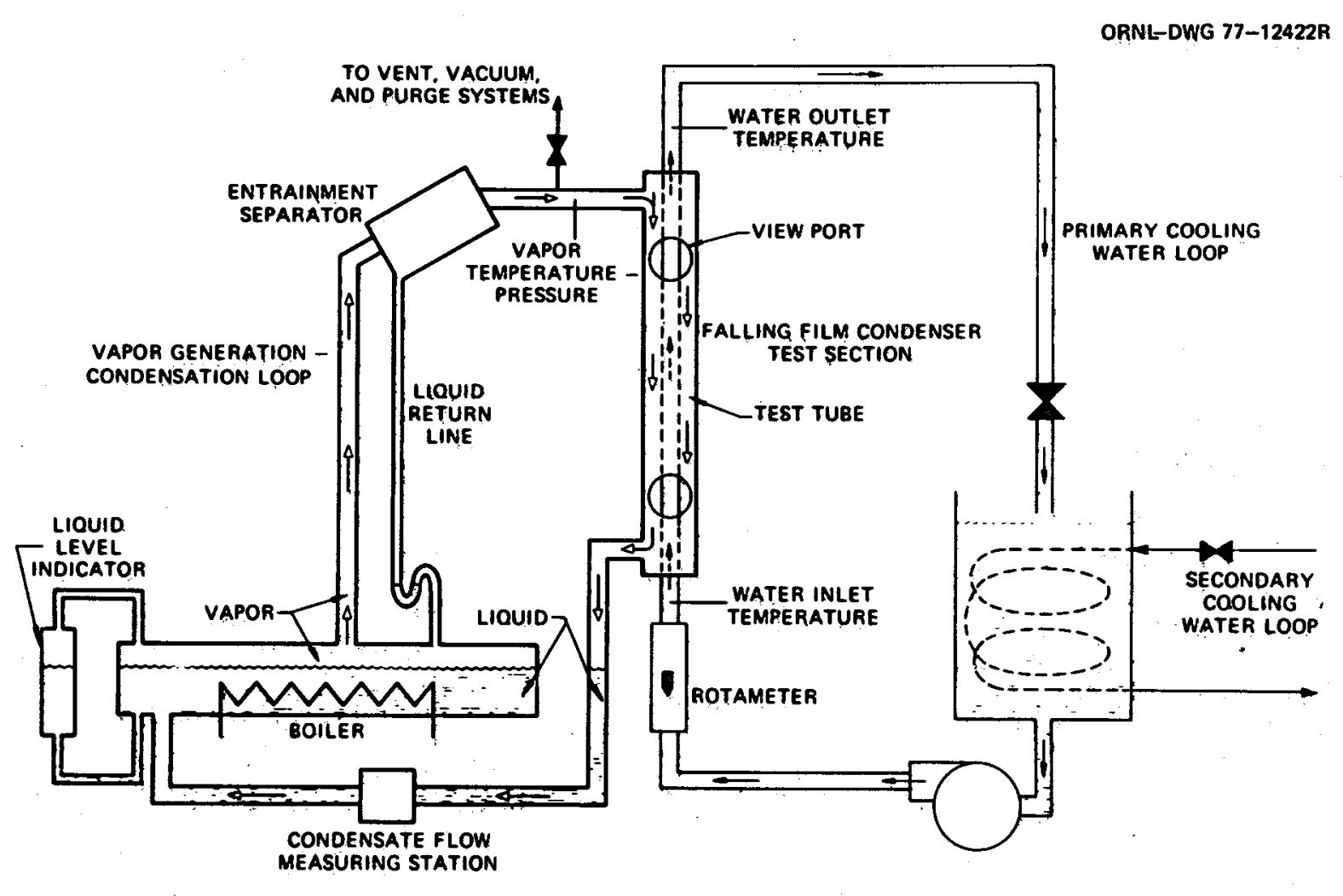

Fig. 2.1. Schematic diagram of experimenta1 apparatus. 
ORNL PHOTO 4688-76

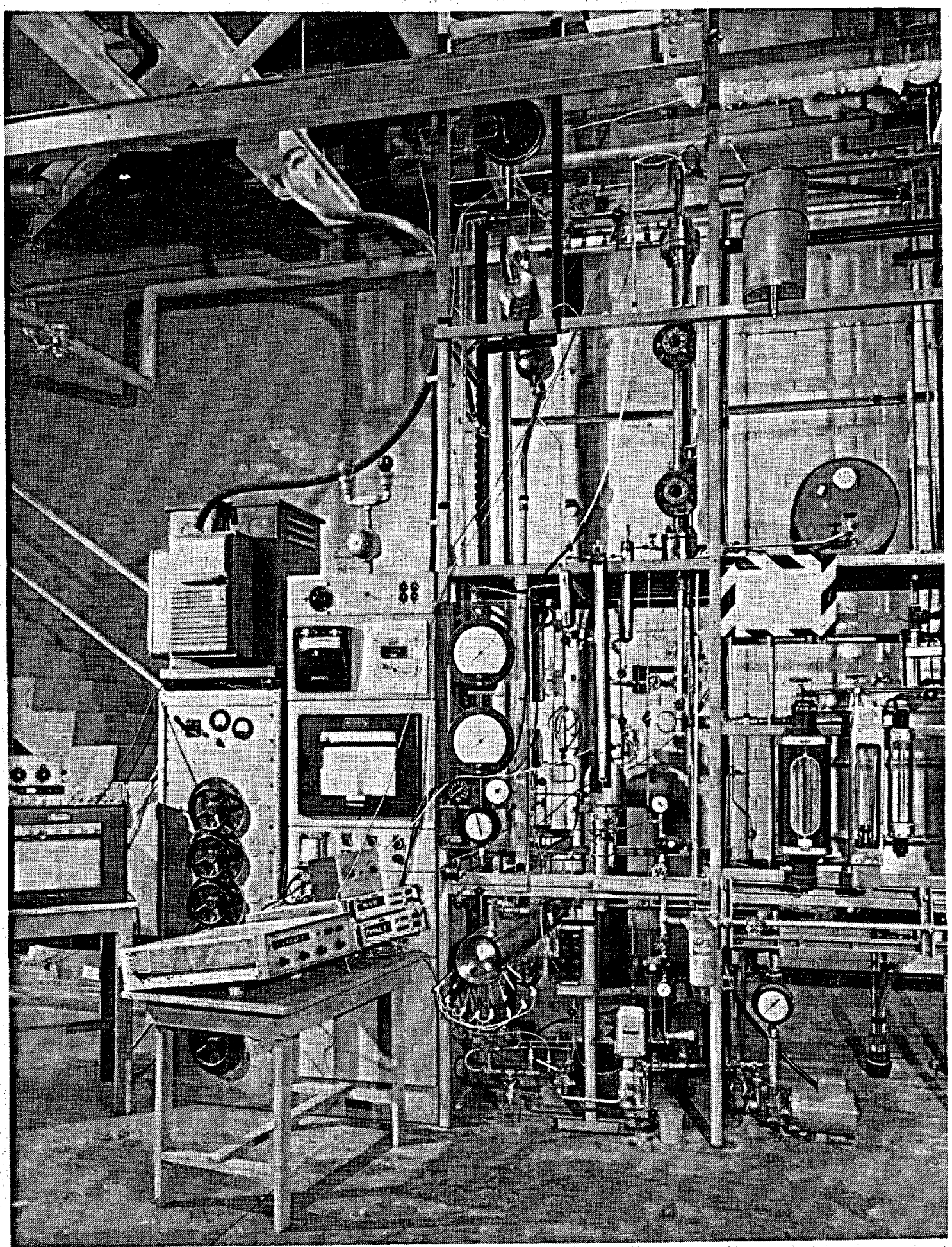

Fig. 2.2. Overall view of test fac1lity. 
Major components of the ORNL test loop include (1) boiler, (2) entrainment separator, (3) condenser module, and (4) condenser water storage tank and pump. A detailed description of each component was presented in an earlier study ${ }^{3}$ and, therefore, will not be repeated in this report. Only a brief summary of the general flow description and condenser tube installation will be given in succeeding sections.

\subsection{General Flow Description}

Flow directions are indicated by arrows in the simplified schematic diagram (Fig. 2.1). The working fluid was vaporized in the boiler and passed through an entraiment separator before entering the condenser test section. The vapor entered at the top of the condenser, and the liquid collected in the separator returned to the boiler. Vapor condensed on the outer surface of the test tube in the test section, exited as a saturated liquid at the condenser bottom, and passed through a condensate measuring station before returning to the bottom of the boiler to complete the closed loop. A pump was not needed for the circulation

of $\mathrm{R}-11$ because the liquid head in the test section side of the loop furnished the driving force required for flow through the condensate measuring station.

In the primary cooling loop, demineralized water was circulated by a small centrifugal pump from a storage tank upward through the condenser test section and back to the storage tank. The primary coolant flow was measured by rotameters upstream of the test section and was controlled by a manually operated valve located downstream of the test section.

The secondary cooling loop removed the heat load from the system by transferring the heat from the primary cooling water to the plant process water that circulated through a cooling coil in the storage tank. The secondary coolant flow rates were regulated by manually operated valves and were measured by rotameters located upstream of the cooling coil. Plant process water-line pressure furnished adequate circulation through the secondary cooling loop. 


\subsection{Condenser Tube and Installation}

The heads on the condenser test section (Fig. 2.3) were designed to seal around a smooth 2.54-cm-OD (1-in.) tube. Experimental test tubes, other than a smooth $2.54-\mathrm{cm}-0 \mathrm{D}$ (1-in.), were prepared by soldering or welding a $2.54-\mathrm{cm}\left(1-\mathrm{in}_{.}\right)$sleeve $13.34 \mathrm{~cm}(5.25 \mathrm{in.})$ long to each end of a 1.17-m (46-in.) length of tube. For installation, the upper section of the top head was removed and the test tube was inserted downward into the test section until the bottom sleeve slid through the three 0-ring seals in the bottom head. The upper section of the top head was then slipped over the top sleeve and bolted to the lower section to complete the shell-side sealing operation. Then, the required connections were made to the primary cooling loop.

A $1.27-\mathrm{cm}-0 \mathrm{D}$ ( $(0.5-i n$.$) stainless steel rod was installed through the$ center of the condenser section (inside the test tube) to decrease the hydraulic diameter and to increase the water velocity for a given primary cooling volume flow. Both variations tended to increase the water-side heat transfer coefficients and, as a result, improved the accuracy of the Wilson-plot technique ${ }^{6}$ used to interpret the experimental data.

\subsection{Test Tubes}

In an earlier report, ${ }^{3}$ the heat transfer performance of 14 tubes of 6 distinct types was presented for a variety of fluorocarbons (including R-11) condensing vertically on the outside tube wall. Letter designations ( $A, B, C, D, \ldots, K$ ) were used to identify these tubes. Other tubes tested were designated by $D-1, F-1, F-3$, and $F-7$; these tubes were a variation of tube type $D$ and $F$ created by attaching rubber skirts (Fig. 2.4) to the outside wall (the integer denotes the number of skirts on the tube). The skirts divided the tubes into two, four, or eight equal condensing lengths and aided condensate drainage from the outside tube surface.

Data for 12 additional tubes and the previously tested smooth Tube $A$ are reported in this study. A letter designation and integer notation 


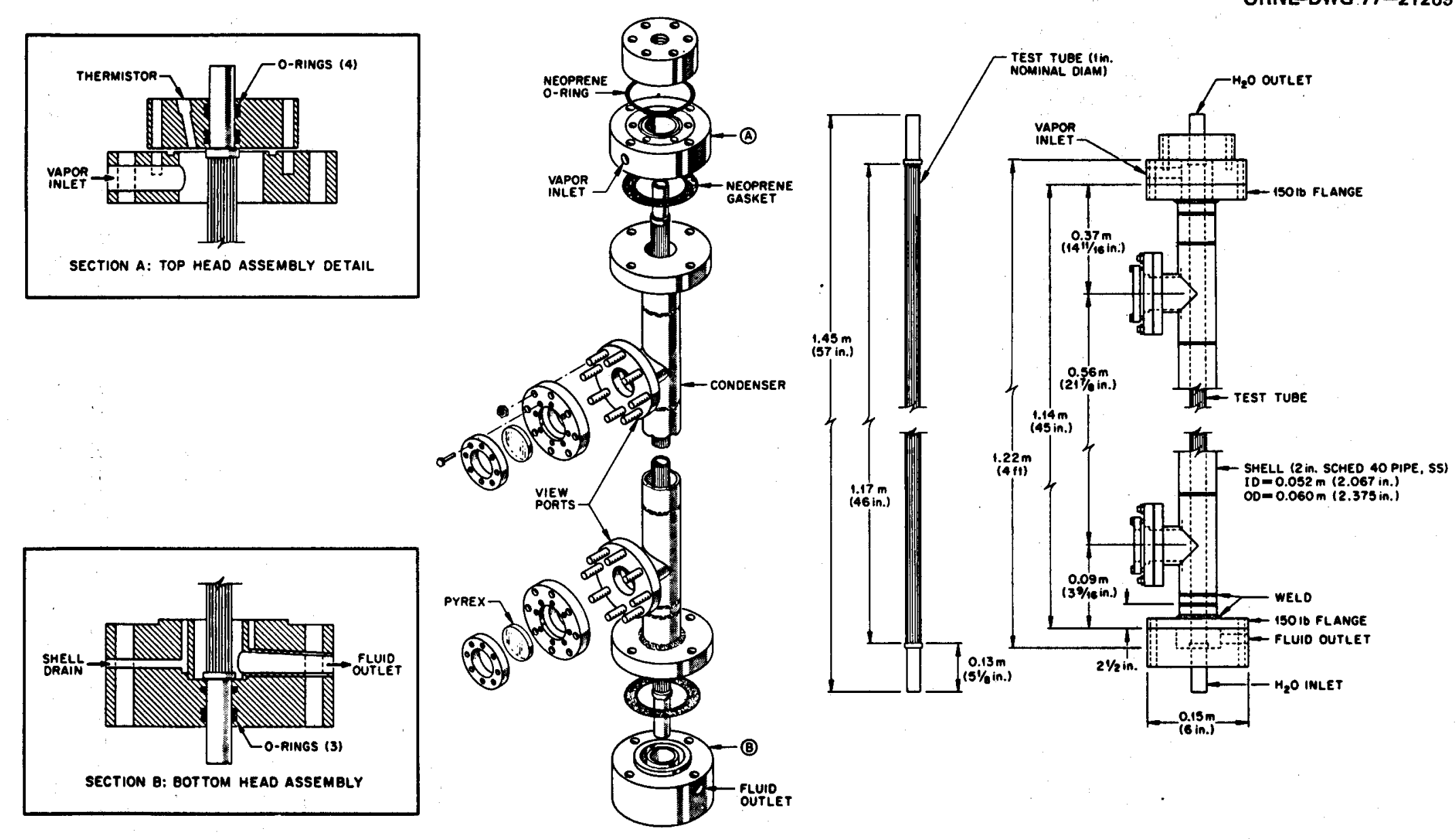

Fig. 2.3. Details of condenser test section.

C 


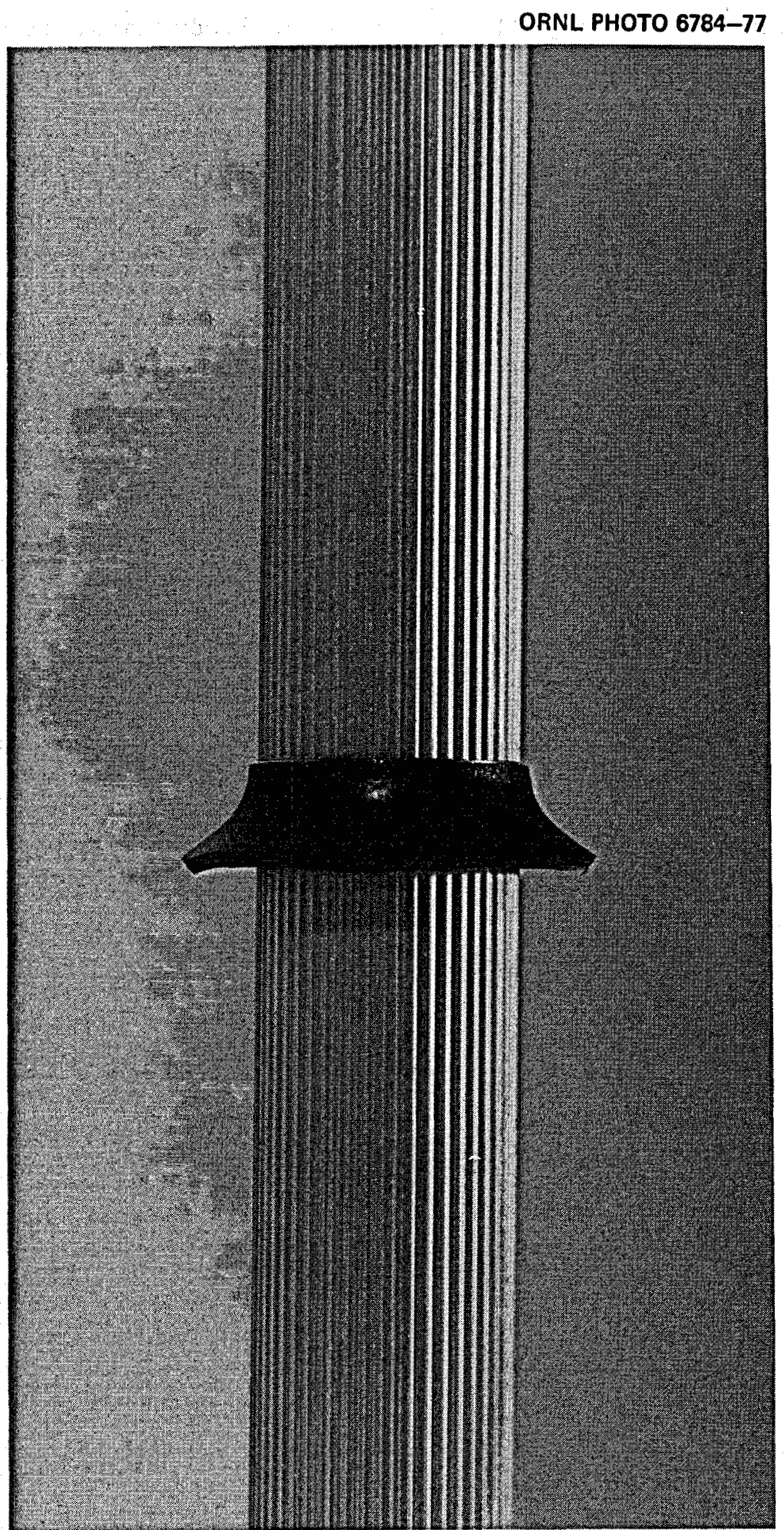

F1g. 2.4. Photograph of a sample test tube with a neoprene skirt attached at midpoint of condensing length. 
are also used to identify the tubes. Detailed descriptions and letter designations of the tubes are given in Table 2.1. Enlarged photographs of sample test tubes are presented in Figs. 2.5 through 2.8 .

Al1 tubes were made of aluminum except types $M$ ( $90 / 10$ cupronickel), R (304 stainless steel), S (409 stainless steel), T (carbon steel), and U (aluminum-brass). Tubes $L, L-1$, and $L-3$ had a smooth inside surface and 60 external rounded flutes, with zero, one, and three skirts, respectively. Tube $I^{*}$ had 90 internal and 60 external flutes (identical to Tube $L$ ). Tubes $M$ and $N$ had roped type surfaces, whereas Tubes $O, R$, and $S$ featured asymetrical spiral surfaces. Tube $T$ (similar to Tube $E$ in

Table 2.1. Charactertstics of tubes

[Nominal 2.54-cm (1-in.) OD, 1.2-m (4-ft) length]

\begin{tabular}{|c|c|c|c|c|c|c|}
\hline \multirow{2}{*}{ Tube } & \multirow{2}{*}{ Description } & \multirow{2}{*}{ Material } & \multirow{2}{*}{$\begin{array}{l}\text { External } \\
\text { surface } \\
\text { area } \\
\left(\mathrm{m}^{2}\right)\end{array}$} & \multicolumn{2}{|c|}{ Flutes } & \multirow{2}{*}{$\begin{array}{r}\text { Pitch } \\
\text { (cm) }\end{array}$} \\
\hline & & & & External & Internal & \\
\hline A & Smooth wall & Aluminum $606 \overline{1}$ & 0.0973 & 0 & 0 & \\
\hline L & $\begin{array}{l}\text { Precision Extru- } \\
\text { sions, Inc. } \\
\text { (single fluted) }\end{array}$ & Aluminum 6061 & 0.1397 & 60 & 0 & \\
\hline$L^{*}$ & $\begin{array}{l}\text { Precision Extru- } \\
\text { slons, Inc. } \\
\text { (double fluted) }\end{array}$ & Aluminum 6061 & 0.1397 & 60 & 90 & \\
\hline$\dot{M}$ & $\begin{array}{l}\text { Wolverine Koro- } \\
\text { dense (roped } \\
\text { type) }\end{array}$ & CupronIcke1 & $0.0980^{a}$ & & & 0.975 \\
\hline $\mathbf{N}$ & $\begin{array}{l}\text { Wolverine Koro- } \\
\text { dense (roped } \\
\text { type) }\end{array}$ & Aluminum & $0.0982^{a}$ & & & 1.283 \\
\hline 0 & $\begin{array}{l}\text { Turbotec (spiral } \\
\text { tube) }\end{array}$ & Aluminum $3003 \mathrm{H}-14$ & $0.1031^{a}$ & & & $0.991-1.069$ \\
\hline $\mathbf{R}$ & $\begin{array}{l}\text { General Atomic } \\
\text { (spiral) }\end{array}$ & Stainless steel 304 & $0.1054^{a}$ & & & \\
\hline $\mathbf{s}$ & $\begin{array}{l}\text { General Atomic } \\
\text { (spiral) }\end{array}$ & Stainless steel 409 & $0.0985^{a}$ & & & $b$ \\
\hline $\mathrm{T}^{c}$ & $\begin{array}{l}\text { Grob Inc. (single } \\
\text { fluted) }\end{array}$ & Carbon steel 1010 & 0.1491 & 60 & 0 & $d$ \\
\hline U & $\begin{array}{l}\text { Yorkshire, U.K. } \\
\text { (corrugated) }\end{array}$ & Aluminum-brass & 0.1150 & 24 & 24 & \\
\hline
\end{tabular}



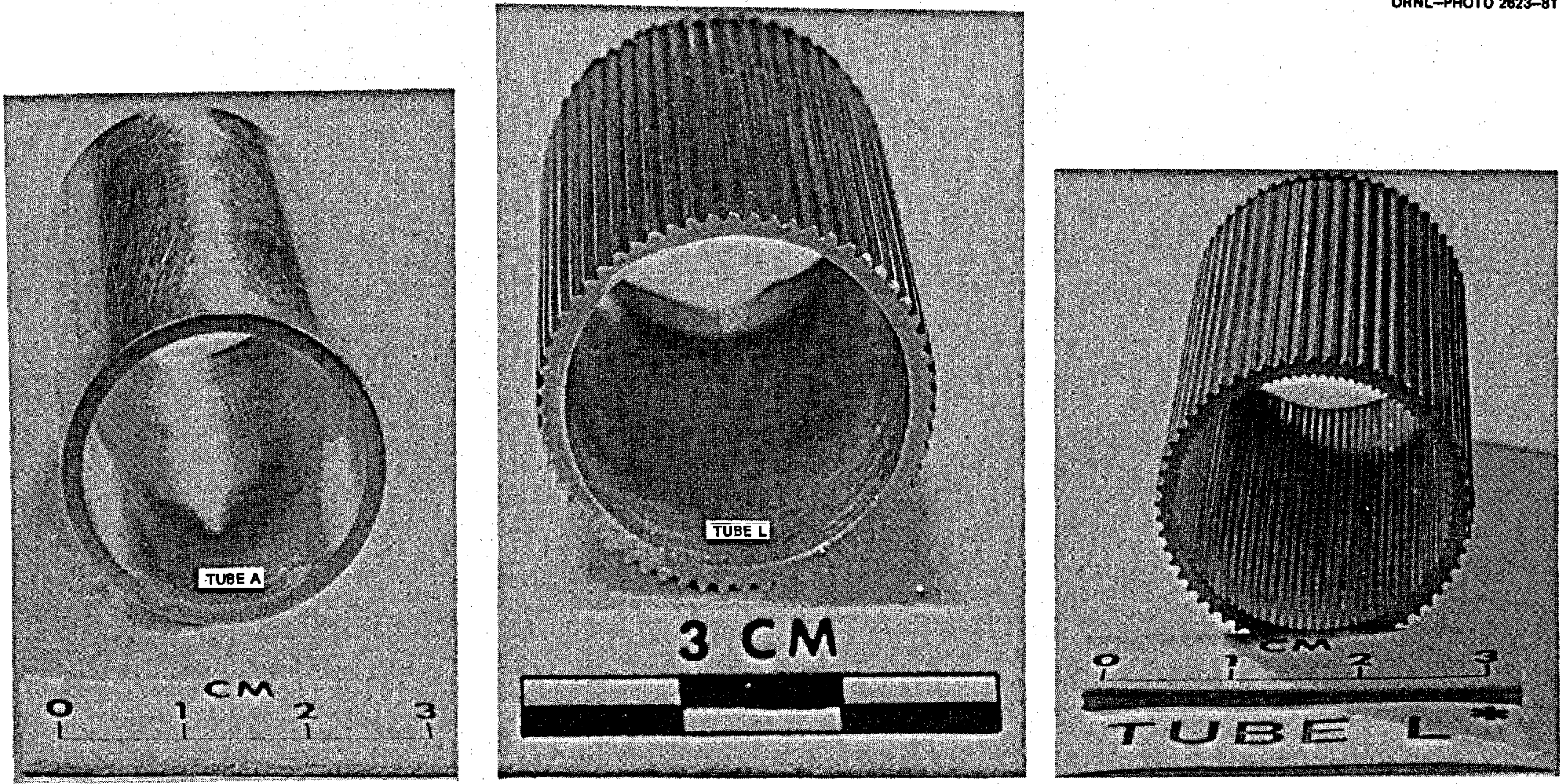

Fig. 2.5. Photographs of tube samples - Tubes $A, L$, and $L^{*}$. 
ORNL-PHOTO 2624-81
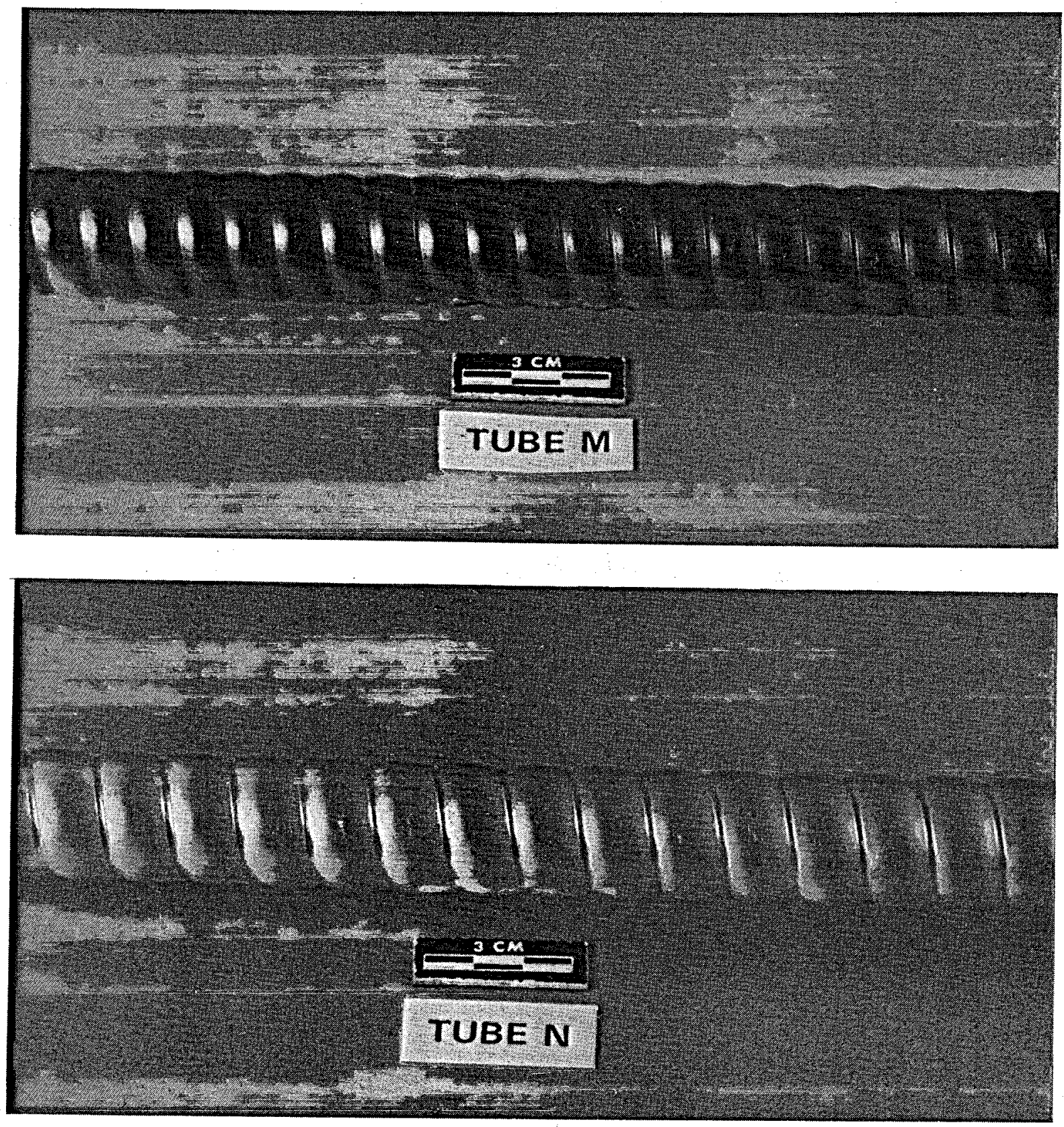

F1g. 2.6. Photographs of tube samples - Tubes $M$ and $N$. 
ORNL-PHOTO 2625-81

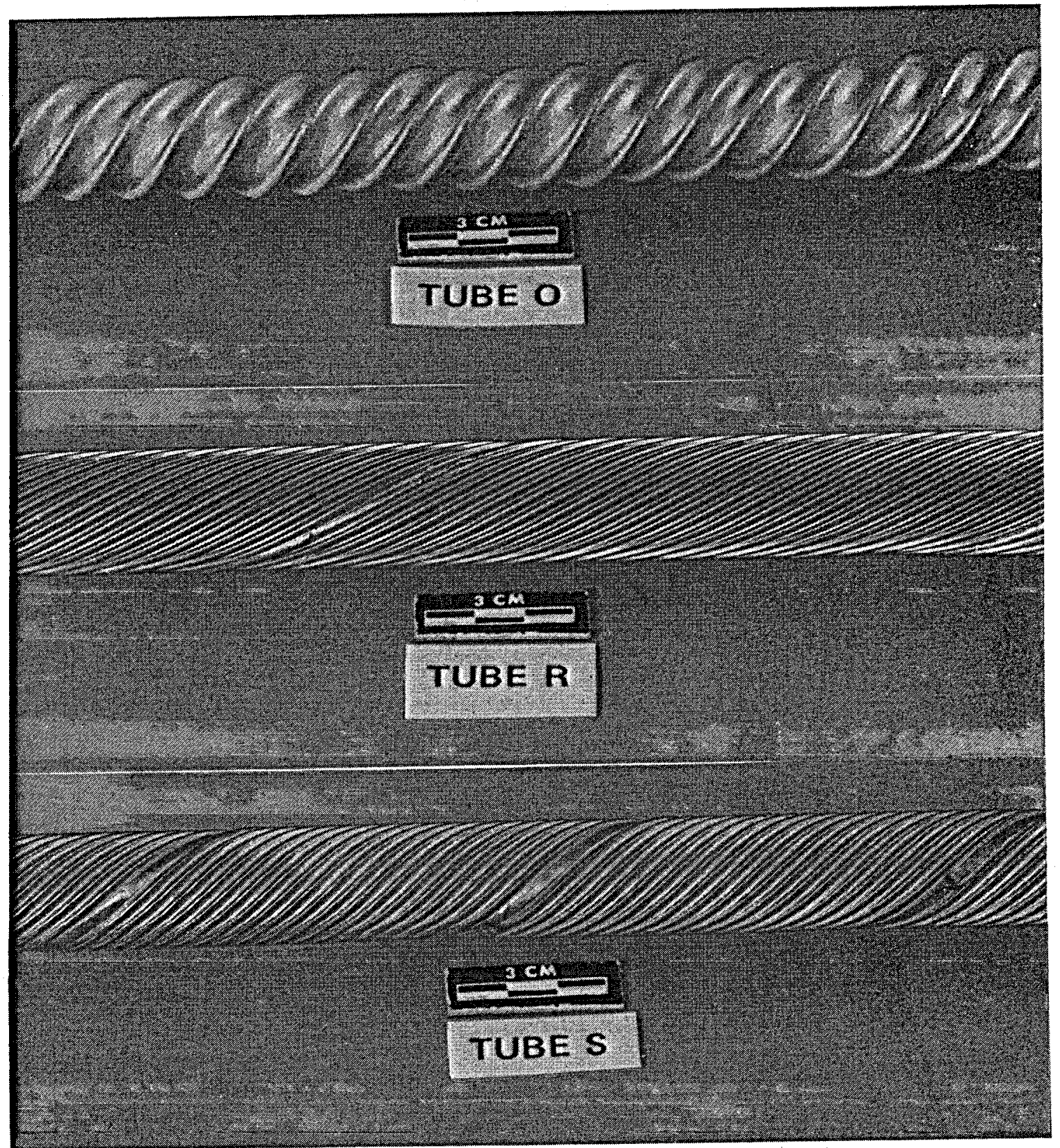

F1g. 2.7. Photographs of tube samples - Tubes $0, R$, and S. 

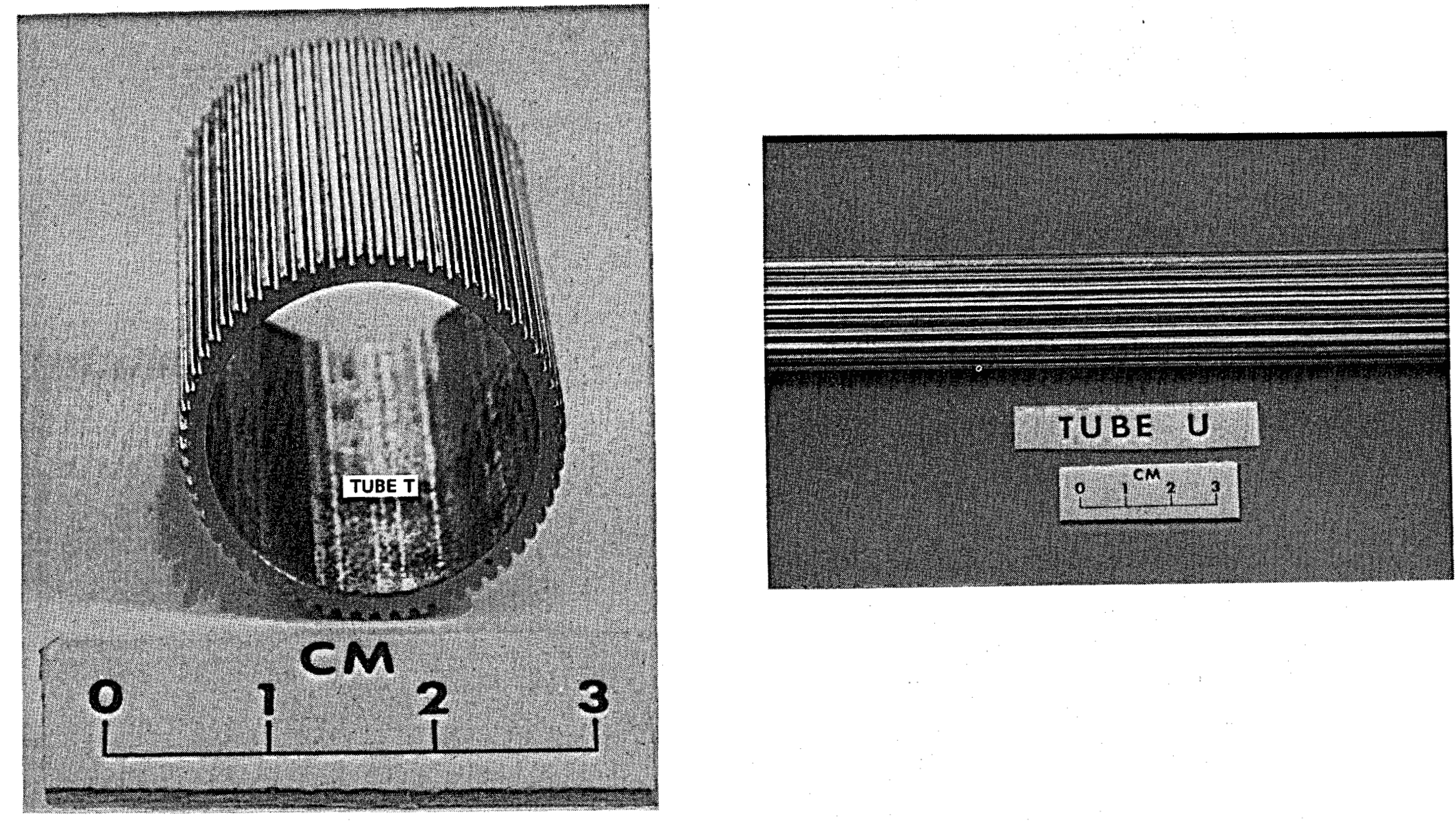

Fig. 2.8. Photographs of tube samples - Tubes $T$ and $U$.

C., 
Ref. 3) had a smooth inside surface and 60 external squared flutes. Tube U featured a similar internal and external corrugated surface.

Tube A was a standard comercial smooth tube. ${ }^{3}$ Tubes $L$ and $L^{*}$ were experimental tubes designed by ORNL and custom made by Precision Extrusions, Inc. Tubes $M$ and $N$ were designed and supplied by the Wo1verine Tube Division of the Universal 0il Products Company under the trade name "Korodense." Tube 0 was designed and supplied by Turbotec Products, Inc. Tubes $R$ and $S$ were designed and supplied by the General Atomic Company. Tube $T$ was custom made by Grob, Inc. Tube $U$ was designed and supplied by Yorkshire Imperial Metals Ltd., United Kingdom.

The external perimeter of most tubes was measured as the length of thin tape forced to conform closely and completely around the tube's outside surface. Measurements were also made from enlarged photographic cross sections of available tube samples. The area of smooth Tube $A$ is based on a 1.22-m (48-in.) length - the total length available within the test section. However, the areas of the enhanced tubes are based on a 1.17-m (46-in.) effective length to account for the 12.7-m (0.5-in.) adapter sleeve and installation clearance on each end of the enhanced tubes. 


\section{PROCEDURES AND INSTRUMENTATION}

The objective of this study was the determination of composite heat transfer coefficients for R-11 condensing on the outside surface of vertical tubes. To apply the Wilson-plot technique to the condensation process, heat rates and temperature differences were calculated from data taken during steady-state operations (see Appendix A for sample calculations). Accurate temperature measurements were critical to the evaluation of condenser performance, because measurement of temperature differences as small as $0.11 \mathrm{~K}\left(0.2^{\circ} \mathrm{F}\right)$ within $\pm 0.02 \mathrm{~K}\left(0.04^{\circ} \mathrm{F}\right)$ was sometimes necessary. Very small condensate flows, 0.19 to $1.89 \times 10^{-5} \mathrm{~m}^{3} / \mathrm{s}$ ( 0.03 to $0.3 \mathrm{gpm}$ ), also had to be measured accurately for good interpretation of the experimental data.

Because the details of the operating procedures and instrumentation are given in a previous report, ${ }^{3}$ only a brief summary will be presented in the following sections.

\subsection{Steady-State Operation}

The heat rate to the boiler was controlled by a stack of four Variacs. Each Variac regulated the voltage to two tubular heaters, and any combination of the four Variacs could be used to obtain experimental heat rates. After setting the heat rate to the boiler, the primary cooling flow rate was set by the valve downstream of the test section. The inlet temperature of the secondary cooling water was determined by the process plant water conditions. The flow rate of the secondary cooling water was used to control the temperature of the primary cooling vater, which, in turn, controlled the vapor temperature in the test section. Temperatures and pressures throughout the system were monitored to determine when a steady state was reached; a steady state existed when no significant change in temperatures $4+0.06$ to $\pm 0.11 \mathrm{~K} \leftarrow 0.1$ to $\pm 0.2^{\circ} \mathrm{F}$ )] occurred through the system over a 5- to 10-min span.

Once a steady state was achieved, the experimental data were recorded. The recorded information included (1) vapor temperature and 
pressure in both the condenser and boiler, (2) flow rate and temperature of the condensate, (3) inlet and outlet temperatures and flow rates of the primary and secondary coolants, and (4) voltage and current to each pair of heater rods. These data were then used to calculate heat transfer rates and temperature differences in the system and to check pressure-temperature values against saturation data in the literature (see Appendix A for examples).

After the data were recorded for a given steady-state condition, the flow rates of the primary and secondary cooling water were adjusted until the system reached a new steady state. The experimental data were again recorded. This same procedure was repeated until data were collected for three to five primary coolant flow rates at the same boiler heat rate. In the experiments, the five primary cooling rates ranged from 0.13 to $1.48 \times 10^{-3} \mathrm{~m}^{3} / \mathrm{s}(2.0$ to $23.5 \mathrm{gpm})$. The heat rate to the boiler was then changed, and the procedure was repeated at the new heat rate.

\subsection{Instrumentation}

The power input to the boiler was monitored by voltage and current measurements for each pair of tubular heaters. The pressures in the boiler and condenser vere measured with Bourdon gauges (Beise Model H-19178). The R-11 loop was also equipped with a compound gauge for reading both low and subatmospheric pressures. Alternatively, subatmospheric pressures could be measured by means of a mercury manometer containing traps to prevent mercury from entering the test section.

Throughout this study, Chromel-Alumel thermocouples and thermistors (Thermometrics Part No. S-10-4 Wire) were used as temperature measurement elements in the system. Thermocouples were located (1) in the liquid and vapor of the boiler, (2) in the vapor feed to the test section, (3) in the inlet and outlet of both cooling water loops, (4) near the condensate measuring station, and (5) on each heater. The recorded thermocouple data were used in deciding when the system reached a steady state. 
Thermistors were added to the system for greater accuracy. These thermistors were installed in the water inlet and outlet lines of the test section and in the vapor feed to the test section. A thermistor was also located near the condensate measuring station. All thermistors were wired to a switch box that permitted individual resistance readout on a digital multimeter - Hewlett-Packard Model 3465 A for the initial experiments and Data Precision Model 3500 for later investigations. The information from the thermistors was used for data reduction because of the greater accuracy attributed to these instruments. The two sets of temperature measuring instruments were checked against each other to increase confidence in their measurements.

The condensate flow in the $R-11$ loop could be measured by two instruments, an integral orifice meter and a turbine flow transducer. These two instruments were arranged in parallel, and the piping permitted the flow to pass through either device. During this investigation, the turbine flow transducer (Flow Technology, Model FTM-A15-LJS) equipped with a range-extending amplifier (Flow Technology, Model LFA$300 \mathrm{~A}$ ) was used to facilitate operation because the integral orifice meter would have required frequent changes in orifice plates to accommodate various flow ranges. The range-extending amplifier made it possible to cover the full range of interest, 0.19 to $1.89 \times 10^{-5} \mathrm{~m}^{3} / \mathrm{s}(0.03$ to $0.3 \mathrm{gpm}$ ), with only one instrument. Earlier work had shown that measured values from the two instruments agreed to within a few percent. The primary cooling water flow was measured by one of two rotameters in parallel upstream of the test section. The rotameters were capable of covering the operating range of 0.13 to $1.48 \times 10^{-3} \mathrm{~m}^{3} / \mathrm{s}$ (2 to $23.5 \mathrm{gpm}$ ). The information from these two rotameters is utilized in the data reduction (see Appendix A).

The secondary cooling water flow was measured by one of two rotameters in parallel upstream of the cooling coil. The rotameters were used for monitoring secondary coolant flows up to $2.52 \times 10^{-4} \mathrm{~m}^{3} / \mathrm{s}(4 \mathrm{gpm})$. 


\section{ANALYSIS}

\subsection{Overal1 Condensing Coefficients}

The overall heat transfer conductance (coefficient) in the condenser is given by:

$$
U=\frac{Q}{A_{0} \overline{\Delta T}},
$$

where $\overline{\Delta T}$ is the overall mean temperature difference between the condensing refrigerant vapor and the primary cooling water, $A_{0}$ is the total outside heat transfer surface area of the tube, and $Q$ is the condenser heat rate.

The arithmetic mean difference is used for $\overline{\Delta T}$, because, in most cases, the temperature difference across the water was relatively small. Therefore:

$$
\overline{\Delta T}=T_{v}-\left(T_{w, \text { in }}+T_{w, \text { out }}\right) / 2
$$

where $T_{v}$ is the vapor temperature and the second term on the right is the average of the inlet water temperature $\left(T_{w, i n}\right)$ and the outlet water temperature ( $\left.T_{w, o u t}\right)$.

Three independent ways to determine the heat rate $(Q)$ of the condenser test section are (1) from the refrigerant side of the condenser, (2) from the primary cooling water passing through the condenser, and (3) from the secondary cooling water passing through a coil located within the primary cooling water storage tank. For this study, the first method was the most accurate and was used exclusively in all calculations in this report, but other methods agreed well. The condenser heat transfer rate may be determined according to the relation

$$
Q=\dot{m}_{c} h_{f g},
$$


where $\dot{m}_{c}$ is the condensate mass flow rate and $\mathrm{h}_{\mathrm{fg}_{\mathrm{g}}}$ is the latent heat of the condensing fluid. In this analysis, all physical property data for R-11 are taken from ASHRAE handbooks. ${ }^{7-9}$

The overall heat transfer coefficient, based on the total tube outside surface area, can be calculated from Eq. (4.1) using Eq. (4.2) to calculate $\overline{\Delta \mathrm{T}}$ and $\mathrm{Eq} .(4.3)$ to calculate $Q$.

\subsection{Individual Heat Transfer Coefficients}

The overall resistance to heat flow $(\Sigma R=1 / U)$ in the condenser is equal to the sum of the individual resistances; therefore,

$$
\frac{1}{U}=R_{v}+R_{w a 11}+R_{w}+R_{f o}+R_{f i}
$$

where $R_{v}$ is the resistance on the vapor (condensing) side, $R_{\text {wall }}$ is that of the wall, $R_{w}$ is that of the water side, and $R_{f o}$ and $R_{f i}$ account for any fouling resistance on the outside and inside surfaces of the tube, respectively. If fouling is neglected and individual heat transfer coefficients ( $h$ ) are introduced, the overall resistance based on the outside surface area becomes:

$$
\frac{1}{\mathrm{U}}=\frac{1}{h_{v}}+R_{w a 11}+\frac{A_{0}}{A_{i} h_{w}},
$$

where $h_{v}$ is the condensing side heat transfer coefficient, $h_{w}$ is the water-side coefficient, and $A_{i}$ and $A_{0}$ are the total inside and outside surface areas of the tube, respectively.

For a smooth tube, the wall resistance based on the outside tube area is given by:

$$
R_{\text {wall }}=r_{0} \operatorname{Ln}\left(r_{0} / r_{i}\right) / k \text {, }
$$

where $k$ is the tube wall thermal conductivity, $r_{0}$ is the outside radius, and $r_{i}$ is the inside radius of the tube. However, the wall resistance caused by the more complicated wall geometry and heat distribution 
is very difficult to estimate for enhanced tubes. To compare the performance between smooth and enhanced tubes, a combined resistance (or inverse conductance) comprised of the condensing side and wall resistance of the tube was defined. Thus a "composite" resistance $\left(1 / h_{c}\right)$ can be represented as:

$$
\frac{1}{h_{c}}=\frac{1}{h_{v}}+R_{w a 11} .
$$

Substituting Eq. (4.7) into Eq. (4.5) and rearranging in a composite coefficient $\left(h_{c}\right)$ form gives:

$$
h_{c}=1 /\left(\frac{1}{\delta}-\frac{A_{0}}{A_{i w} h_{w}}\right)
$$

Similarly, a corresponding composite (combined) temperature difference can be defined as:

$$
\Delta \mathrm{T}_{\mathrm{c}}=\frac{\mathrm{Q}}{\mathrm{h}_{\mathrm{c}} \mathrm{A}_{\mathrm{o}}}
$$

which represents the temperature difference between the condensing vapor and the inside tube wall.

The composite quantities are derived by elimination of the waterside film coefficient contribution to the overall resistances. The next step in the analysis is the evaluation of the water-side coefficients.

\subsection{Evaluation of Water-Side Coefficients by the Wilson-P1ot Method}

The method used in this study for determining water-side coefficients was a technique introduced by Wilson; ${ }^{6}$ this technique is a graphic method of interpreting overall coefficients so that individual condensing-side coefficients can be evaluated. The following treatment presents this method and describes its application to the data in this study. 
Heglecting the effects of changes in water temperature, the waterside resistance $\left(1 / h_{w}\right)$ for turbulent flow ${ }^{10-12}$ as a function of water velocity ( $v$ ) may be approximated by:

$$
\left(1 / h_{w}\right) \propto\left(1 / 0^{0.8}\right)
$$

therefore, Eq. $(4.5)$ can be rewritten as:

$$
\frac{1}{\bar{U}}=\frac{1}{h_{v}}+R_{w a 11}+a_{1} v^{-0.8}
$$

If, following wilson, the sum of the first two resistances $\left(1 / h_{v}+R_{w a l l}\right)$ is taken as approximately constant, Eq. (4.11) becomes:

$$
\frac{1}{\bar{J}}=a_{0}+a_{1} \mathrm{v}^{-0.8}
$$

In this form, a plot of $1 / 0$ v6 $v^{-0.8}$ on rectangular coordinates should give a straight line from which the constants $a_{0}$ ( $y$-intercept) and a (slope) can be determined. Because ao is the sum of the first two resistances (vapor side plus wali) in Eq. (4.11), substitution and rearrangement of $\mathrm{Eq} \cdot(4,7)$ yields:

$$
h_{c}=1 / a_{0}
$$

which is the parameter of interest in this analysis.

For the experimental data points used in the construction of the wilson plot, a constant heat load and a condensate flow rate were maintained while varying the water-side velocities. Because properties for R-il did not vary significantly over the small range of temperatures covered in this study, no appreciable error was introduced by assuming the sum of the vapor side and tube wall resistances $\left(1 / h_{v}+R_{\text {wall }}\right)$ to be essentially constant. 


\section{RESULTS AND DISCUSSION}

Experimental tests in this study were divided into six categories: (1) tests on two external fluted tubes ( $L$ and $T$ ); (2) tests on three skirted tubes $(A-1, I-1$, and $I-3)$, one with a smooth outside surface, the others with external fluted surfaces; (3) tests on two tubes with roped type surfaces ( $M$ and $N$ ); (4) tests on three spiral type tubes ( 0 , $R$, and S): (5) tests on a corrugated type tube (U); and (6) tests on a double fluted tube $\left(L^{*}\right)$.

Figures 5.1 to 5.9 present heat transfer results from this study. Condensing experiments conducted in this investigation (113 runs yielding 450 heat transfer data points) are documented in Appendix $c$ (Tables C.2 through C.13), where the data are tabulated with the overall condensing heat transfer coefficients and heat balance checks for the

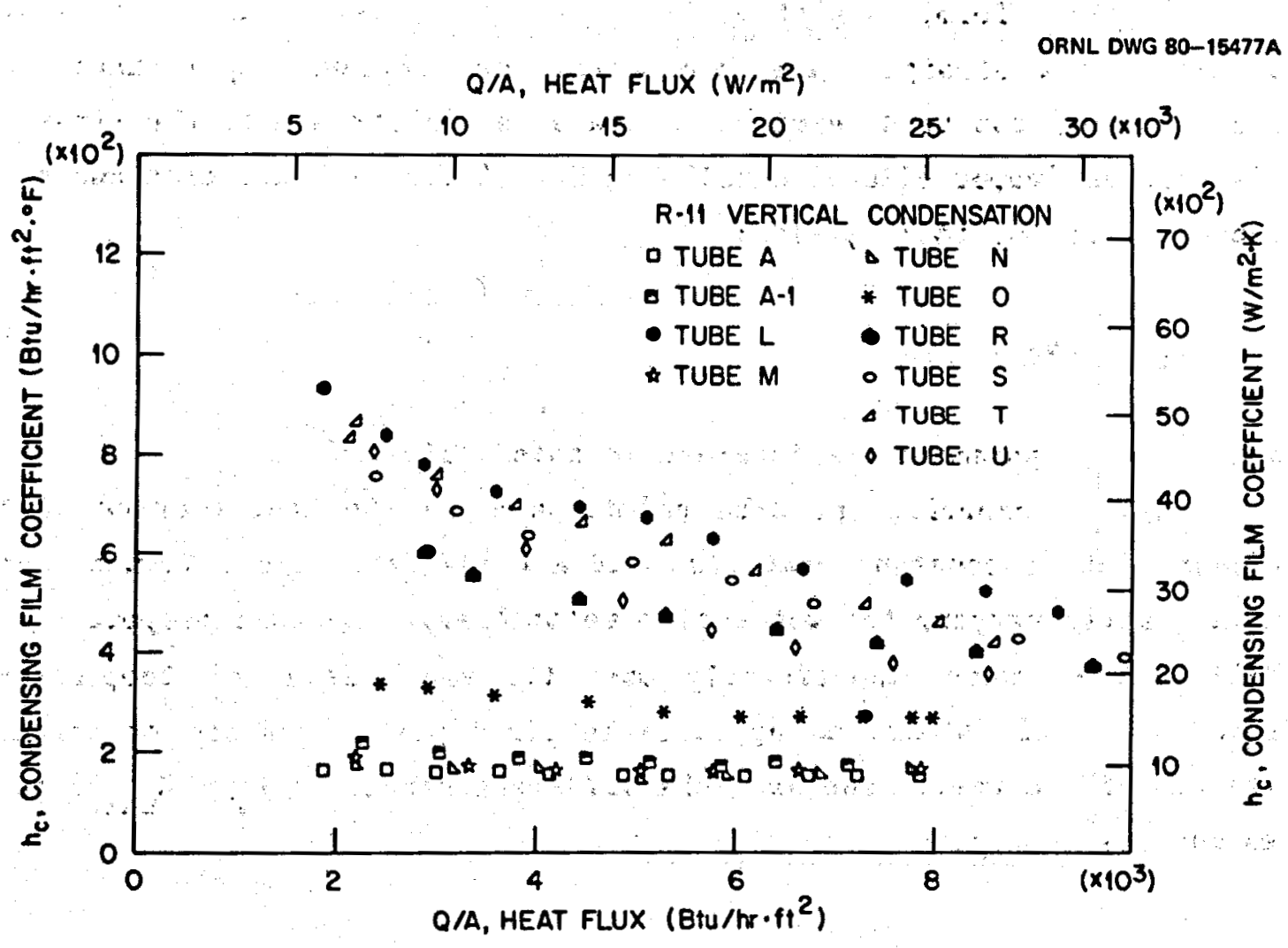

F1g. 5.1. Wilson-plot results for fluted tubes on a composite heat transfer coefficient vs heat flux basis. 


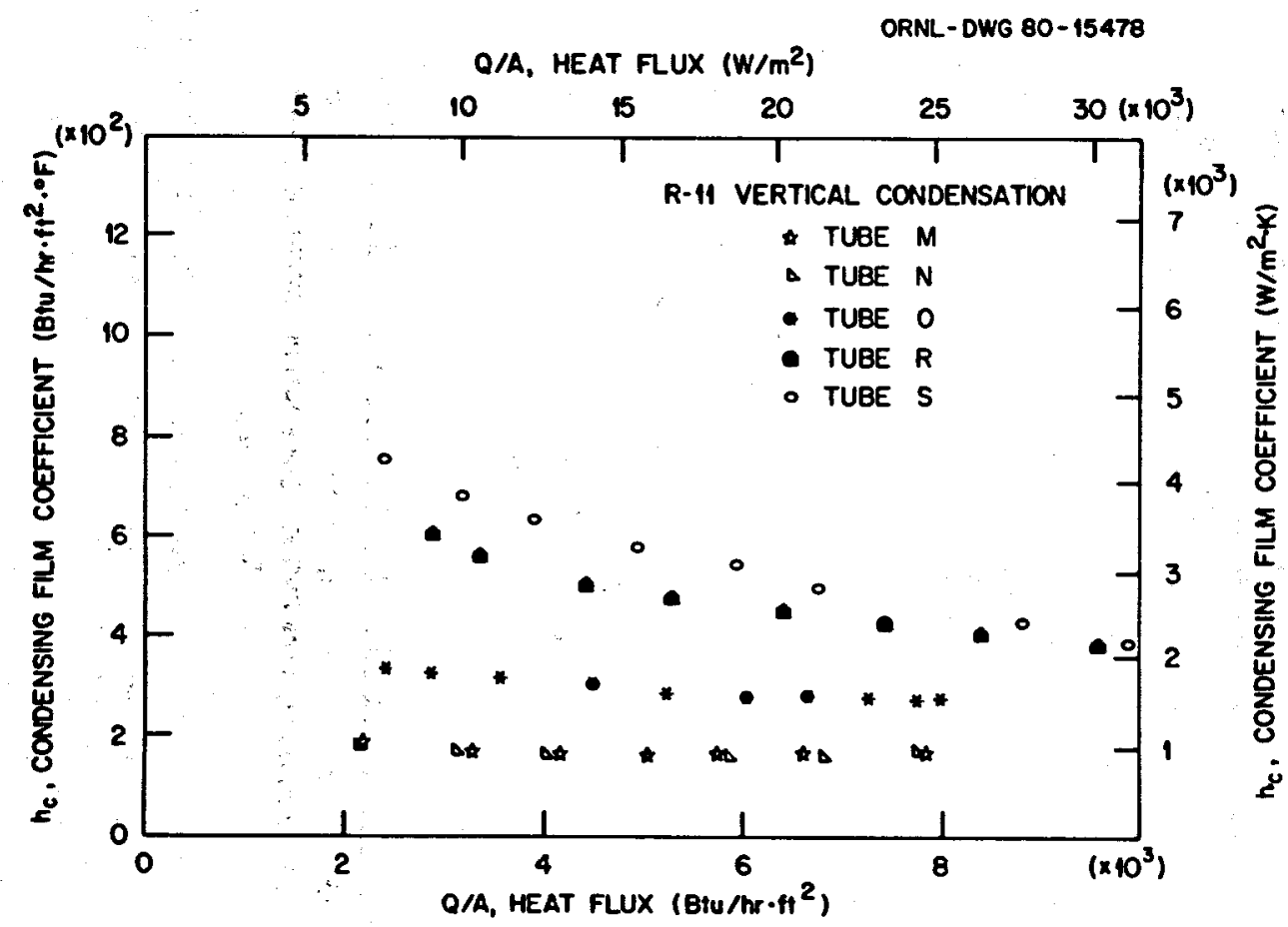

Fig. 5.2. Wilson-plot results for Tubes $M, N, O, R$, and $S$ on a composite heat transfer coefficient vs heat flux basis.

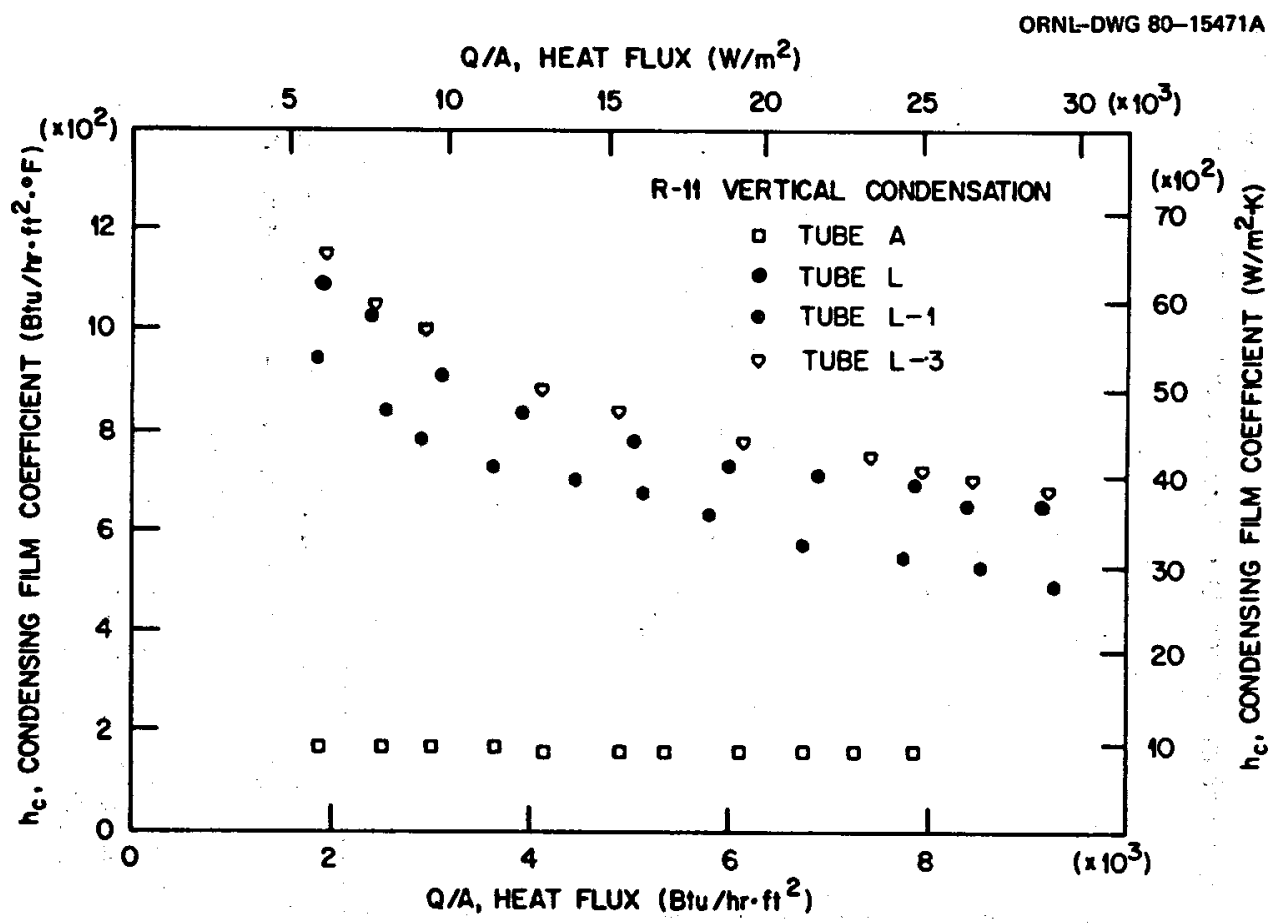

Fig. 5.3. Wilson-plot results for Tube L and duplicate tubes (containing equally spaced drainage skirts) on a composite heat transfer coefficient vs heat flux basis. 
OANL-DWG 80-15472A $\triangle T$, COMPOSITE CONOENSING TEMPERATURE DIFFERENCE (K)

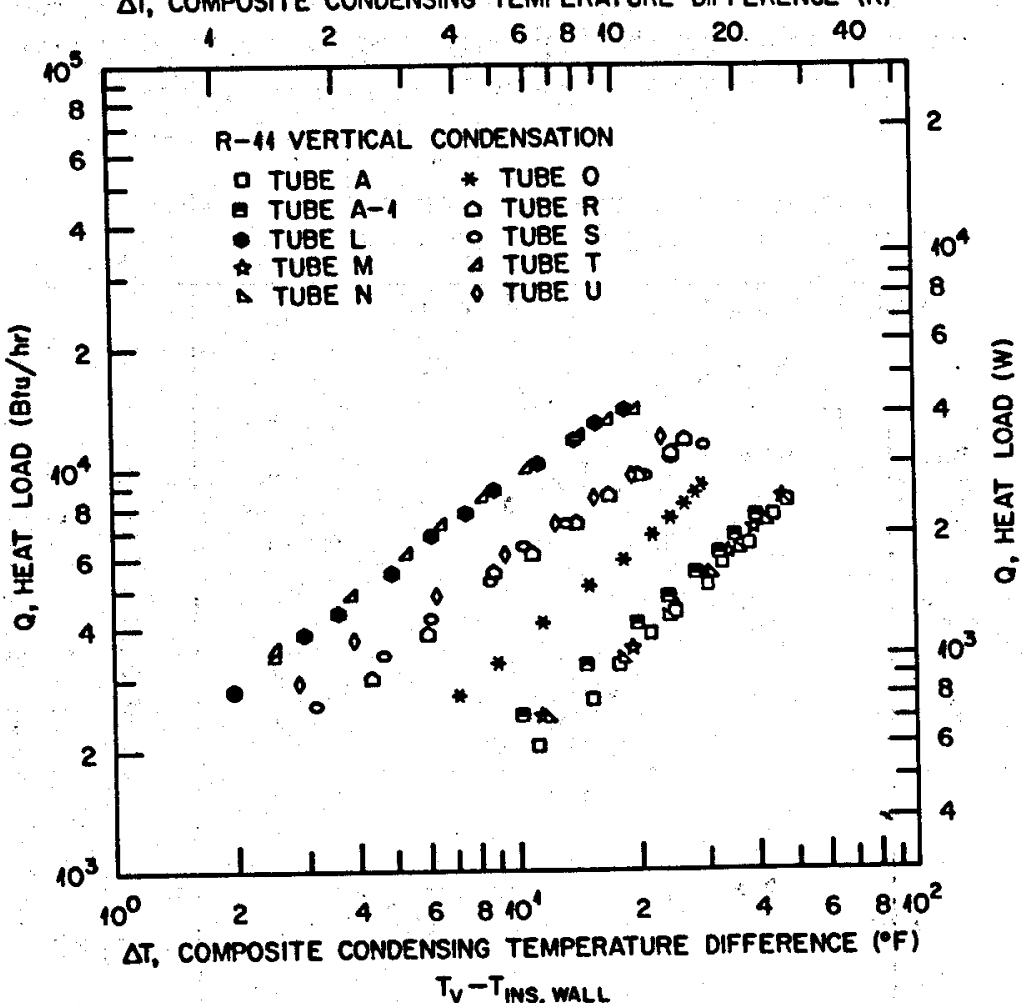

Fig. 5.4. Wilson-plot results for fluted tubes on a heat load vs composite temperature difference basis.
ORML-OWG 80-1547 $\triangle T$, COMPOSITE CONDENSING TEMPERATURE DIFFERENCE (K)

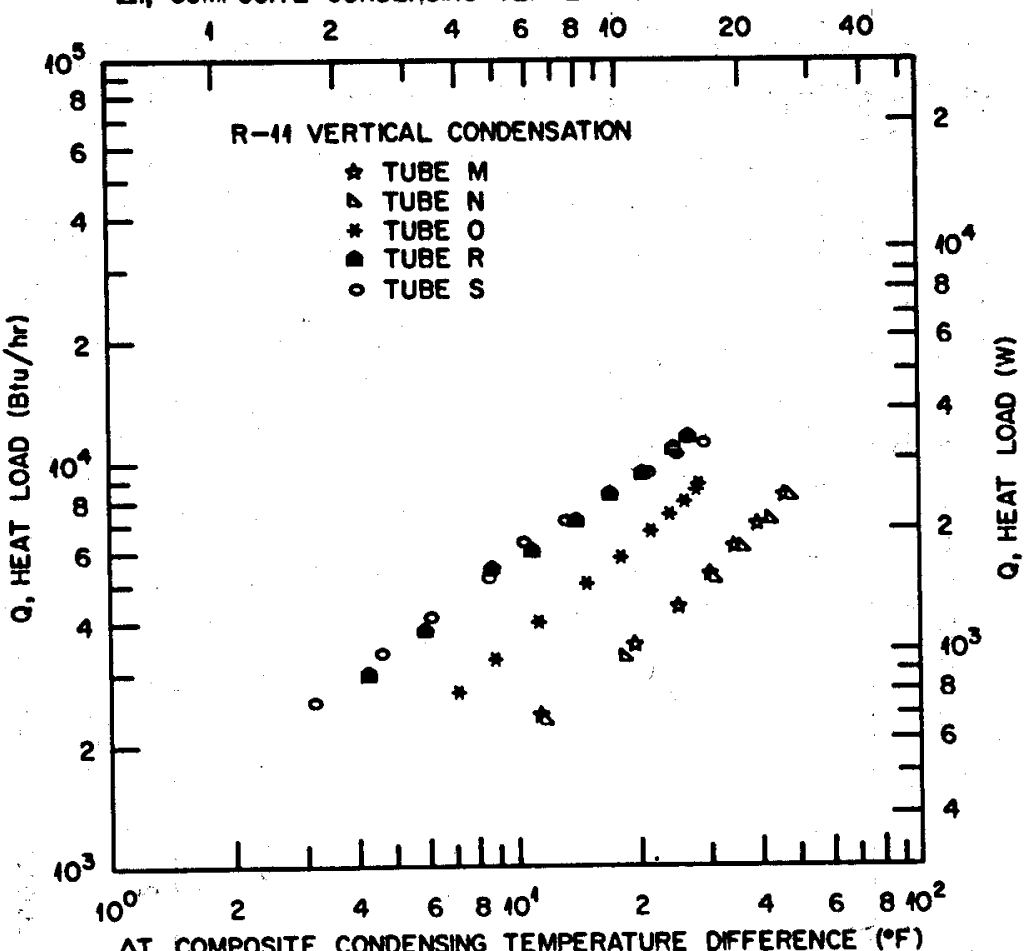

$$
T_{V}-T_{\text {INS. maLL }}
$$

F1g. 5.5. W1lson-plot results for Tubes $M$, $N, O, R$, and $S$ on a heat load vs composite temperature difference basis. 
ORNL-DWS BO-15473 $\triangle T$. COMPOSITE CONDENSING TEMPERATURE DIFFERENCE (K)

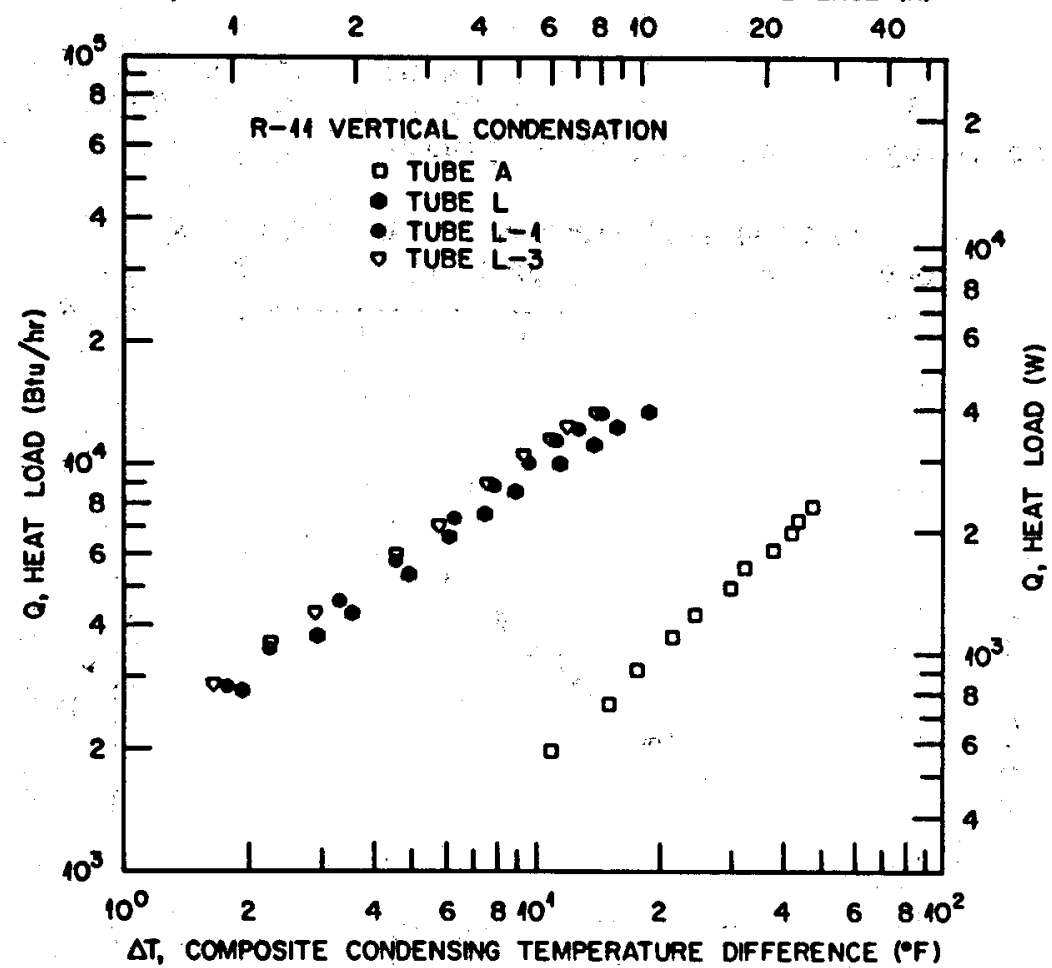

$T_{V}-T_{\text {WS. WALL }}$

F1g. 5.6. Wilson-plot results for Tube $L$ and duplicate tubes (contalning equally spaced drainage skirts) on a heat load vs composite temperature difference basis.

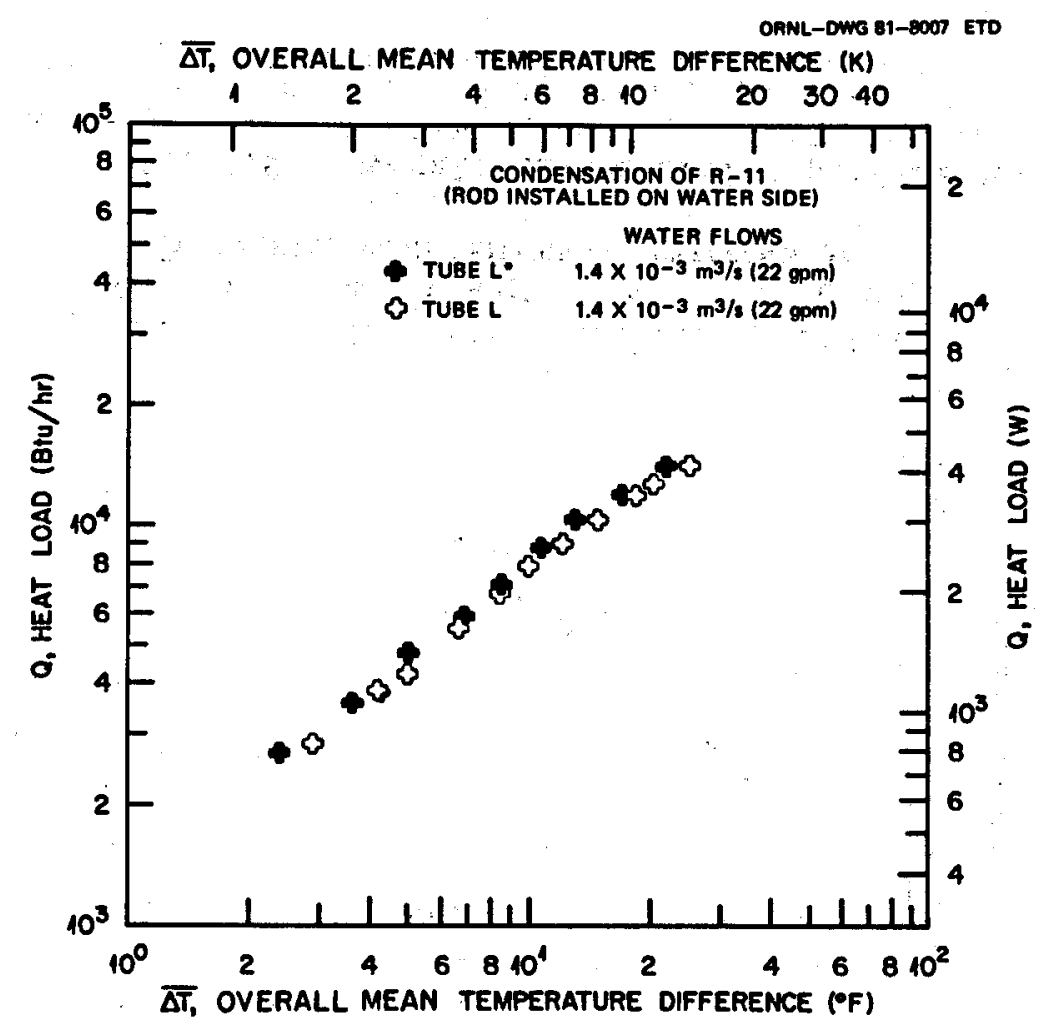

F1g. 5.7. Overall heat transfer performance of Tubes $L$ and $L^{*}$ with water flowing through an annulus at $1.4 \times 10^{-3} \mathrm{~m}^{3} / \mathrm{s}(22 \mathrm{gpm})$. 


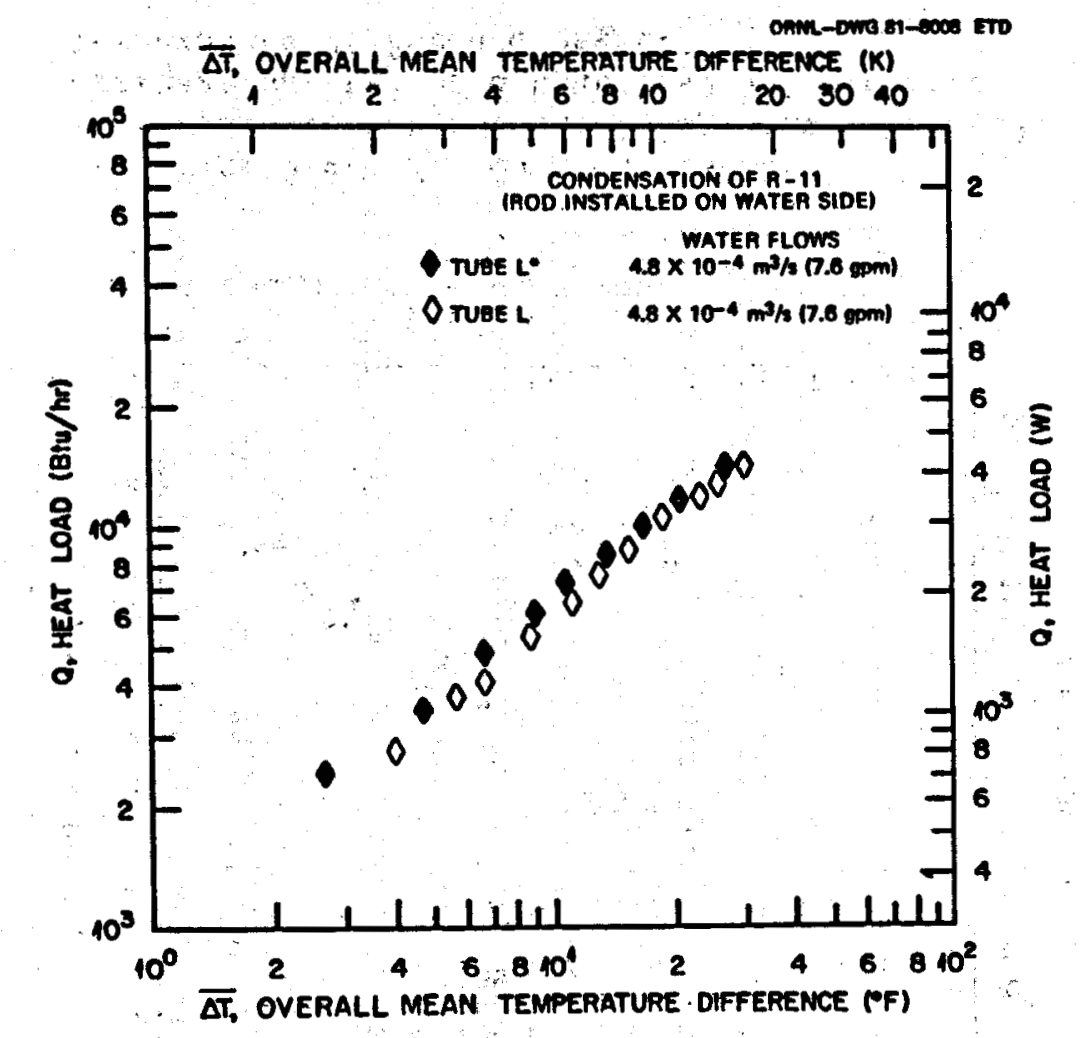

Fig. 5.8. Overall heat transfer performance of Tubes $L$ and $L^{*}$ with water flowing through an annulus at $4.8 \times 10^{-4} \mathrm{~m}^{3} / \mathrm{s}(7.6 \mathrm{gpm})$.

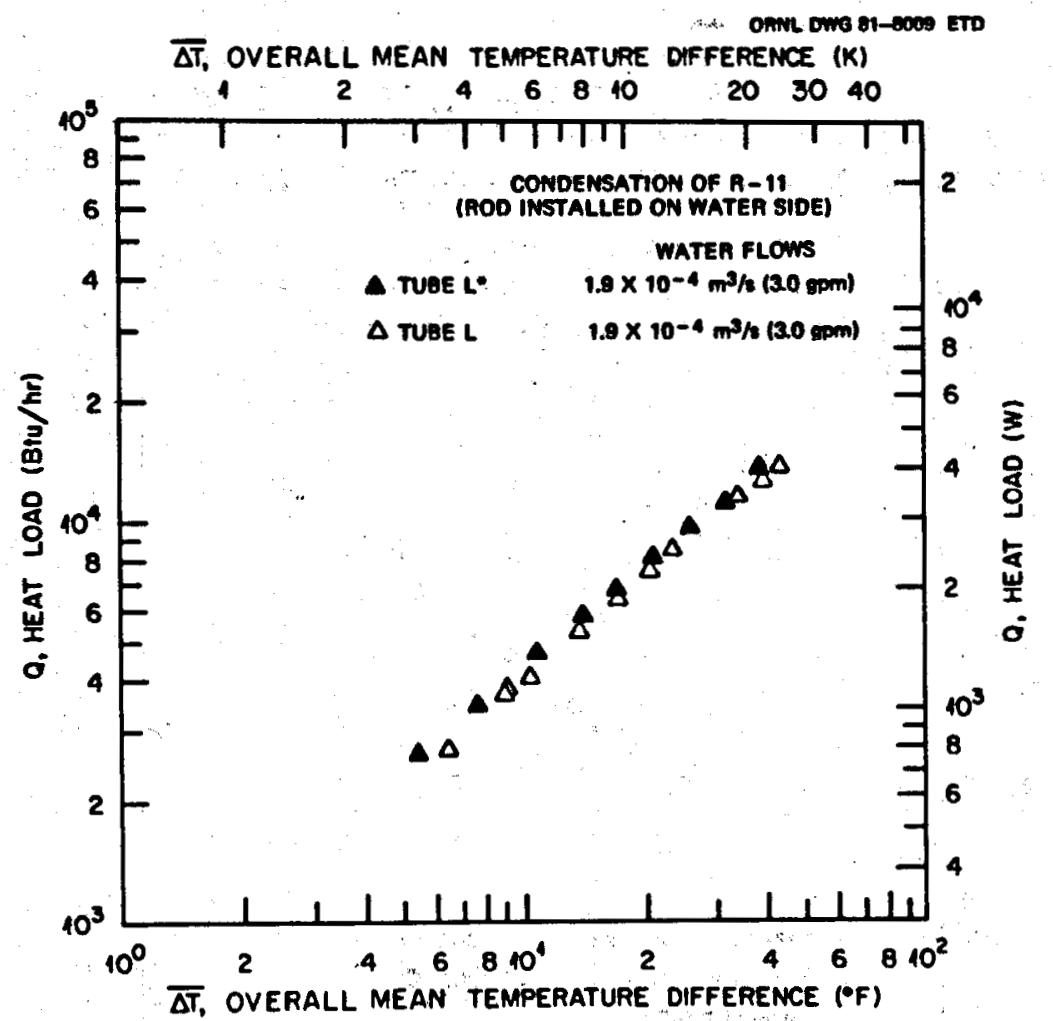

ง

F1g. 5.9. Overail heat transfer performance of Tubes $L$ and $L^{*}$ with water flowing through an annulus at $1.9 \times 10^{-4} \mathrm{~m}^{3} / \mathrm{s}$ (3.0 gpm). 
condenser test section. Table C.1, which serves as the data basis for comparison, is taken from Ref. 3 .

Wilson-plot results are tabulated in Appendix B, and a sample Wilson plot is given in Appendix A with sample calculations.

Parameter ranges for the experiments were

- condensing temperature: 306 to $326 \mathrm{~K}$ (92 to $128^{\circ} \mathrm{F}$ ),

- condensing pressure: 137.9 to $255 \mathrm{kPa}$ (20 to $37 \mathrm{psia}$ ),

- heat load: 790 to. 3,090 W $(2,700$ to $10,550 \mathrm{Btu} / \mathrm{h})$,

- heat flux: 5,675 to $31,375 \mathrm{~W} / \mathrm{m}^{2}\left(1,800\right.$ to $\left.9,950 \mathrm{Btu} / \mathrm{h} \cdot \mathrm{ft}^{2}\right)$.

The resulting composite condensing heat transfer coefficients $\left(h_{c}\right)$ ranged from 850 to $6530 \mathrm{~W} / \mathrm{m}^{2} \cdot \mathrm{K}\left(150\right.$ to $\left.1150 \mathrm{Btu} / \mathrm{h} \cdot \mathrm{ft}^{2} \cdot{ }^{\circ} \mathrm{F}\right)$; composite condensing temperature differences $\left(\Delta T_{c}\right)$ range from 0.9 to $27 \mathrm{R}(1.7$ to $48^{\circ} \mathrm{F}$ ).

Dimensional plots (Figs. 5.1 to 5.9) are intended as aids for design of heat exchanger equipment operating within the specified parameter ranges.

\subsection{Enhanced Tube Results}

The R-11 data for all tubes, except the double fluted tube $L^{*}$, are shown in Figs. 5.1 through 5.3 in dimensional form as composite condensing heat transfer coefficient $\left(h_{c}\right)$ vs heat flux $(Q / A)$. Because of the uncertainties and difficulties involved in computing the wall resistance for the enhanced tubes, Figs. 5.1 through 5.3 present a composite condensing film coefficient $\left(h_{c}\right)$ that includes both the vaporside and wall resistances. Both ordinate and abscissa are also based on the total condensing area for each tube (Table 2.1). Therefore, any observed augmentation resulting from an area effect is essentially accounted for.

In a previous study, 3 data were presented for $R-11$ condensing vertically on the outside of Tube A (smooth walls). Data for Tube A from 
Fig. 15 in Ref. 3 are plotted in Figs. 5.1 and 5.3 for baseline comparison with the tubes tested in this study. As indicated in these figures, the date for Tube $A$ showed very little variation in heat transfer coefficient for the heat flux range tested.

In Figs. 5.1 and 5.2, the $R-11$ data for Tubes $M$ and $N$ (roped surfaces) show no significant variation in heat transfer coefficient with increasing heat flux. In fact, the data for Tubes $M$ and N (Fig. 5.1) fall within the normal scatter of the data for Tube A. Therefore, for Tubes $M$ and $N$, the surface characteristic (geometry) and/or differences in material (Table 2.1) apparently had little effect on heat transfer performance during vertical condensation.

In Figs. 5.1 and 5.2 , the heat transfer coefficients for Tube 0 (spiral surface) are somewhat higher than those for Tubes $M$ and $N$ and decrease very slightly with increasing heat flux.

Coefficients for Tubes $R$ and $S$ (also spiral) start considerably above those for Tube 0 and decrease more rapidly with increasing heat flux. Coefficients for Tube $S$ are also higher than those for Tube $R$ at the lower heat fluxes, but decrease to approximately Tube $R$ values at high heat fluxes.

In Fig. 5.1, coefficients for Tube 0 (corrugated) lie slightly above those for Tube $S$ at low fluxes but decrease quite sharply to values below Tube $R$ at high fluxes. Coefficients for Tubes $T$ and $L$ (externally fluted) start somewhat above those for Tube $U$ at the low heat fluxes, decreasing to values above Tube $S$ at high fluxes.

At the $10 \mathrm{w}$ heat fluxes $\left[<14,190 \mathrm{~W} / \mathrm{m}^{2}\left(<4,500 \mathrm{Btu} / \mathrm{h} \cdot \mathrm{ft}^{2}\right)\right]$, Tubes $\mathrm{T}$ and $L$ seem to have approximately the same performance; whereas at the higher fluxes $\left[>14,190 \mathrm{~W} / \mathrm{m}^{2}\left(>4,500 \mathrm{Btu} / \mathrm{h} \cdot \mathrm{ft}^{2}\right)\right]$, the coefficients for Tubes $T$ and $L$ decrease rapidly, with values for Tube $T$ falling below those for Tube $L$.

In many cases for $\mathrm{R}-11$, the condensing oide resistance appears to dominate the heat transfer process, so that water-side enhancement is of less interest. However, many tubes tested in this study (roped, spiral, and double fluted) offer some enhancement on the cooling water side. Except for Tube $L^{\text {h }}$ (double fluted), the use of the Wilson-plot method on 
these water-side enhanced tubes gave satisfactory condensing-side, results. For the double fluted Tube $L^{*}$, however, some appreciable error was introduced when the Wilson-plot method was used to determine composite condensing coefficients. Consequently, no Wilson-plot results for Tube $L^{*}$ are presented in this report. The reason that the Wilsonplot method gave somewhat inaccurate results for Tube $L^{*}$ is not clear. One possible explanation is that the water-side coefficient for Tube $L^{*}$ may not be the simple function of water velocity assumed for the Wilson plot. More specifically, because the Wilson-plot procedure is based on an $\mathbf{0 . 8}$ power dependence of the water-side coefficient on flow rate, such an assumption may not necessarily apply to the water-side characteristic of Tube $L^{*}$.

A better presentation of the data for Tube $L^{*}$ is shown in Figs. 5.7 through 5.9, where only overall heat transfer results are plotted in the form of heat load vs overall mean temperature difference. A discussion describing the overall heat transfer results for Tube $L^{*}$ will be presented in a later section.

For a given heat flux, the maximum composite heat transfer coefficient achieved for a nonskirted fluted tube was 5.5 times the smooth tube value (Fig. 5.1), occurring at the lowest test heat flux $5,991 \mathrm{~W} / \mathrm{m}^{2}$ $\left(1,900 \mathrm{Btu} / \mathrm{h} \cdot \mathrm{ft}^{2}\right)$ with Tube $\mathrm{L}$. The corresponding minimum composite coefficient for Tube $L$ was 3.5 times at a higher heat flux of $24,754 \mathrm{~W} / \mathrm{m}^{2}$ $\left(7,850 \mathrm{Btu} / \mathrm{h} \cdot \mathrm{ft}^{2}\right)$.

Previous work at ORNL with refrigerants 3,5 had indicated that vertical fluted tube performance can be further enhanced by the use of drain-off skirts, which effectively act to divide the tube into shorter condensing lengths. These drain-off skirts provided improvement at the higher heat fluxes where flooding in the grooves was more pronounced. The effectiveness of skirts on the smooth Tube $A$ and fluted Tube $L$ is shown in Figs. 5.1 and 5.3 , respectively. The tube integer notation denotes the number of attached equally spaced drain-off skirts.

Coefficients for Tube A-1 (0.6-m-long condensing lengths) were enhanced from 1.3 to 1.1 times smooth Tube $A$ values at low and high heat fluxes, respectively (Fig. 5.1). The use of a single skirt on Tube A 
does not appear to be very effective at the higher heat fluxes, where condensate flow rates reach high values. However, the heat transfer performance for Tube A-1 (Fig. 5.1) is somewhat better than that achieved with the commercially enhanced Tubes $M$ and $N$. $^{*}$

Unlike Tube A-1, the use of skirts on Tube $I$ effectively aided condensate drain-off of flooded grooves and increased the heat transfer coefficients at the higher fluxes. Figure 5.3 shows that coefficients were enhanced from 1.1 to 1.3 times for Tube $L-1$ as compared with Tube $L$ at low and high heat fluxes, respectively.

Even further enhancement was possible using additional skirts on Tube L. At a low heat flux $\left[5,991 \mathrm{~W} / \mathrm{m}^{2}\left(1,900 \mathrm{Btu} / \mathrm{h} \cdot \mathrm{ft} \mathrm{t}^{2}\right)\right]$, coefficients for Tube I-3 compared with $L$ resulted in an enhancement ratio of 1.2 . For the higher fluxes $\left[28,860 \mathrm{~W} / \mathrm{m}^{2}\left(\sim 9,152 \mathrm{Btu} / \mathrm{h} \cdot \mathrm{ft}^{2}\right)\right]$, an enhancement ratio of 1.4 was achieved. From Fig. 5.3, the superiority of Tube L-3 can be clearly recognized. At a low heat flux of $5,991 \mathrm{~W} / \mathrm{m}^{2}(1,900$ $\left.B t u / h \cdot f t^{2}\right)$, the maximum enhancement in heat transfer achieved with Tube $\mathrm{L}-3$ was $6,570 \mathrm{~W} / \mathrm{m}^{2} \cdot \mathrm{K}\left(1,157 \mathrm{Btu} / \mathrm{h} \cdot \mathrm{ft} \mathrm{t}^{2}\right)$ compared with $908 \mathrm{~W} / \mathrm{m}^{2} \cdot \mathrm{K}(160$ $\mathrm{Btu} / \mathrm{h} \cdot \mathrm{ft}^{2} \cdot{ }^{\circ} \mathrm{F}$ ) for the smooth Tube A, providing an enhancement ratio of 7.2. This represents the maximum enhancement ratio achieved for any of the tubes discussed in this report. The corresponding minimum enhancement for Tube $\mathrm{L}-3$ was 4.7 times the smooth tube value at a heat flux of $24,754 \mathrm{~W} / \mathrm{m}^{2}\left(7,850 \mathrm{Btu} / \mathrm{h} \cdot \mathrm{ft}^{2}\right)$.

Conclusions from Figs. 5.1 through 5.3 include:

1. External fluted tubes gave better condensing performance than other geometries tested in the vertical condensation mode.

2. The best external fluted tube tested (Tube L) can increase condensing heat transfer coefficients up to 5.5 times smooth tube values for $R-11$ condensing at a given heat flux.

3. Such an enhancement cannot be accounted for by the increased area of the fluted tube, but it may be attributed to surface tension effects as described by Gregorig. 13

*However, these tubes may be intended for use in the horizontal mode, and the enhancement is mostly for water-side improvement. 
4. As found in an earlier study, ${ }^{3}$ the use of skirts on a fluted tube can increase condensing heat transfer coefficients up to 7.2 times smooth tube values at the lower heat fluxes.

5. At the higher fluxes, composite coefficients for a fluted tube with one skirt can be increased up to 1.3 times the corresponding value for a fluted tube with no skirts.

Although Figs. 5.1 through 5.3 are useful for determining whether the observed enhancement was merely an area effect, other dimensional presentations may be more meaningful for particular design situations. In Figs. 5.4 through 5.6, the condensation data are plotted in heatload-vs-composite-condensing-temperature-difference form. This form, an alternative to the previous total area basis, allows the designer to take "credit" for the increased area of the fluted tube. Therefore, for a fixed heat load or condensing temperature difference, enhancement ratios can be evaluated. As illustrated in Figs. 5.4 through 5.6, the performance rank order of the test tubes is essentially unchanged from that indicated in Figs. 5.1 through 5.3, that is, Tube A (worst) through Tube L-3 (best). However, positions of Tubes $R$ and $U$ data relative to that of Tube $\mathbf{S}$ data improve considerably when compared on the heat-loadvs-condensing-temperature basis (Fig. 5.4), because their total surface areas are greater than that of Tube S (Table 2.1). In fact, the heat transfer performances for Tubes $R, S$, and $U$ appear to be similar at the higher heat loadings.

A similar observation may be made about Tube $T$. As indicated in Fig. 5.4, the excellent performance of Tube $T$ is more evident, reflecting its considerable advantage in total area. In this plot, the performance of Tubes $\mathrm{L}$ and $\mathrm{T}$ becomes virtually identical, particularly at the higher heat loads.

For a given condensing temperature difference, fluted tubes can accommodate heat loads up to 4.7 times smooth tube values. At a condensing temperature difference of $6.4 \mathrm{~K}\left(11.6^{\circ} \mathrm{F}\right)$, Tube $\mathrm{L}$ can accomodate a heat load of $2871 \mathrm{~W}(9800 \mathrm{Btu} / \mathrm{h})$, while Tube $A$ can handle only $7167 \mathrm{~W}$ $(2100 \mathrm{Btu} / \mathrm{h})$, therefore giving a heat load ratio of 4.7 ( $\mathrm{Fig} .5 .4)$. Alternatively, for a given heat load, the smooth Tube $A$ required condensing temperature differences up to 7.8 times fluted tube values. For 
example, at a heat load of $806 \mathrm{~W}(2750 \mathrm{Btu} / \mathrm{h})$, the condensing temperature difference required for Tube $A$ was $8.7 \mathrm{~K}\left(15.6^{\circ} \mathrm{F}\right)$ as compared with $1.1 \mathrm{~K}\left(2^{\circ} \mathrm{F}\right)$ for Tube $\mathrm{L}$, therefore, providing a temperature difference ratio of 7.8 .

An analysis on the effectiveness of skirts like those described previously may be made for Tubes $L-3$ and $L-1$ vs plain Tube $L$. The use of skirts on Tube $L$ offered significant improvement throughout the range of heat loads tested (Fig. 5.6). In this form, for a given condensing temperature difference, both maximum and minimum heat loads achieved with Tube $\mathrm{L}-3$ were 1.2 times Tube $\mathrm{L}$ values. However, for a given heat load, the maximum condensing temperature difference ratio (Tube $L$ to Tube $\mathrm{L}-3)$ was 1.4 at the highest heat 1 oad $[4,029 \mathrm{~W}(13,750 \mathrm{Btu} / \mathrm{h})]$. The corresponding minimum condensing temperature difference ratio was 1.3 at the lowest heat $10 a d[850 \mathrm{~W}(2,900 \mathrm{Btu} / \mathrm{h})]$. Therefore, at the higher loads where condensate flooding was more pronounced, Tube L-3 appears to give the greatest performance improvement over Tube $L$. This behavior supports similar findings on previously tested skirted fluted tubes. $^{3}$

The increased performance of Tube $L-3$ may also be compared with that of smooth Tube A. For a given condensing temperature difference, the maximum heat load achieved with Tube L-3 was 6 times the smooth tube value (Fig. 5.6), occurring at the lowest condensing temperature difference $\left[6 \mathrm{~K}\left(11^{\circ} \mathrm{F}\right)\right]$. The corresponding minimum heat load ratio with Tube $\mathrm{L}-3$ was 5.5 at the highest condensing temperature difference $17.8 \mathrm{~K}$ $\left.\left(14^{\circ} \mathrm{F}\right)\right]$.

For a given heat load, the maximum condensing temperature difference ratio (Tube $A$ to Tube $L-3$ ) was 10 at the lowest heat load [ $850 \mathrm{~W}$ $(2900 \mathrm{Btu} / \mathrm{h})]$. The corresponding minimum condensing temperature difference ratio was 7.1 at the highest heat $10 a d$ [ $2403 \mathrm{~W}(8200 \mathrm{Btu} / \mathrm{h})$ ].

Conclusions from Figs, 5.4 through 5.6 include:

1. The best external fluted tube can increase heat load capability to 4.7 times the smooth tube value for $\mathrm{R}-11$ condensing at a given condensing temperature difference; conversely, for a given heat load, a smooth tube can require a condensing temperature difference up to 7.8 times that for the same fluted tube. 
2. The use of skirts on a fluted tube can increase the heat load capability up to six times the smooth tube value for a given condensing temperature difference. Conversely, for a given heat load, a smooth tube can require a condensing temperature difference up to ten times skirted fluted tube value.

\subsection{Double Fluted Tube Results}

As previously mentioned, the favored Wilson-plot method for determining condensing-side heat transfer coefficients was somewhat inaccurate when applied to the double fluted Tube $\mathrm{L}^{*}$. One possible explanation is.that, unlike a smooth inside tube wall, the water-side coefficient for an inside fluted tube is not the simple function of water velocity assumed for the Wilson plot. Therefore, as a result, some appreciable error is introduced when the method is used in determining composite condensing performance of double fluted tubes. Consequently, comparisons of Wilson-plot results between Tube $L^{*}$ and other tubes have the unavoidable penalty of possible substantial uncertainties.

Tests were conducted with Tube $L^{*}$ to determine the effect of inside flutes on the overall heat transfer performance.

To determine such an effect, test results for Tube $L^{*}$, were compared with overall data (collected as a prerequisite to the Wilson-plot method) for Tube $L$, which is externally identical to Tube $I^{*}$ but features a smooth inside tube wall. Experimental overall heat transfer data were obtained for Tube $L^{*}$ with cooling water flowing through an annulus [1.3-cm-diam (0.5-in.) rod inside the tube]. Such a water-side arrangement was necessary to match the water-side configuration used in testing Tube $L$.

Overall heat transfer results for Tubes $L^{*}$ and $L$ are presented in Figs. 5.7 through 5.9 as heat load vs overall mean temperature difference for a series of water flow rates. These figures show how the overall performance for Tubes $L^{*}$ and $I$ increase as the water flow rate increases. In Fig. 5.8, for a given overall temperature difference and a water flow rate of $4.8 \times 10^{-4} \mathrm{~m}^{3} / \mathrm{s}(7.6 \mathrm{gpm})$, the maximum improvement 
in heat load achieved with Tube $\mathrm{L}^{*}$, was $17 \%$ above the comparable Tube $\mathrm{L}$ value, occurring at the lowest overall temperature difference $[2.2 \mathrm{~K}$ $\left.\left(4^{\circ} \mathrm{F}\right)\right]$. At the same water flow rate, the corresponding minimum heat load ratio with Tube $L^{*}$ was 1.09 for an overall temperature difference of $10.4 \mathrm{~K}\left(18.7^{\circ} \mathrm{F}\right)$. Alternatively, for a given heat load (Fig. 5.8), the maximum overall temperature difference ratio (Tube $L$ to Tube $L^{*}$ ) was 1.29 at the lowest heat load $[791 \mathrm{~W}(2,700 \mathrm{Btu} / \mathrm{h})]$. The corresponding minimum was 1.12 at a heat load of $2,930 \mathrm{~W}(10,000 \mathrm{Btu} / \mathrm{h})$. A similar comparison may be made with Figs. 5.7 and 5.9 .

Figures 5.7 through 5.9 show that the inside flutes enhance to some degree the overali heat transfer coefficients of Tube $L^{*}$ over those for Tube $L$. However, a question arises concerning whether the inside flutes result in water-side heat transfer coefficient enhancewent or whether such an increase in overall coefficient is merely caused by an increase in inside surface area alone. The inside surface area of Tube $L^{*}$ is $\sim 1.32$ times that of Tube $L$. For the test conditions inthis report, an area increase of this order could explain the observed increase in overall performance with no increase in water-side heat transfer coefficient.

When condensing-side heat transfer coefficients are very large (low resistance to heat $f(10$ ) as a result of external enhancement, the waterside coefficients will tend to become more dominant (a larger fraction of the total overall resistance) in determining heat flow. In this case, the use of internal flutes appears worthwhile, because additional overall performance improvements may be realized. However, excessive cooling water pressure drop and fabrication costs, resulting from the implementation of internal flutes, could represent considerable penalty to be weighed against any significant performance gains. This represents an area for future trade-off/optimization studies. 
6. CONCLOSIONS

The main conclusions drawn from this study of R-11 condensing on the outside of vertical enhanced tubes may be sumarized as follows:

1. With condensing performance judged on a heat-load-vs-compositecondensing-temperature-difference basis, the rank order (best to worst) of the enhanced tube geometries tested was external fluted tubes, corrugated tube, spiral tubes, and roped type tubes.

2. The best external fluted tube (Tube L) gave much better condensing performance than that of a conventional smooth tube (Tube A). For a given heat flux, the maximum composite heat transfer coefficient achieved with Tube $L$ was 5.5 times the Tube $A$ value, occurring at the lowest test heat flux. For a given condensing temperature difference, Tube $L$ was capable of accomodating a heat load up to 4.7 times the Tube A value. For a given heat load, Tube A required a condensing temperature difference of up to 7.8 times the fluted Tube $L$ value.

3. The use of skirts on the best fluted tube further increased composite condensing coefficients, therefore yielding an improved performance factor of 7.2 over smooth tube values, at the lower heat fluxes. These results support earlier findings with other skirted fluted tubes. 3,5

4. For a double fluted tube, the inside tube fluting increased the overall heat transfer coefficient to as much as $17 \%$ over that for a tube with identical outside flutes and a smooth inside surface. 
REFERENCES

1. R. C. Robertson, Waste Heat Rejection from Geothermal Power Stations, ORNL/TM-6533 (December. 1978).

2. S. R. Combs, An Experimental Study of Heat Transfer Enhancement for Ammonia Condensing on Vertical Fluted Tubes, ORNL-5356 (January 1978).

3. S. K. Combs, G. S. Mallen, and R. W. Murphy, Condensation of Refrigerants on Vertical Fluted Tubes, ORNL/TM-5848 (August 1978).

4. J. W. Michel and R. W. Murphy, "Condenser Designs for Binary Cycles," p. 449 in Proceedings of the 15th Intersociety Energy Conversion Engineering Conference, Seattle; Washington, August 1882 198Q Vol. 1, The American Institute of Aeronautics and Astronautics, New York, 1980.

5. J. W. Michel and R. W. Murphy, "Enhanced Condensation Heat Transfer, ", paper presented at the 19th AIChE National Heat Transfer Conference, Orlando, Florida, August 1980.

6. E. E. Wilson, "Basis for Rational Design of Heat Transfer Apparatus," Trans. Am. Soc. Mech. Engrs. 37, 47 (1915).

7. "Propertles of Refrigerants," Chap. 14, p. 268 in ASHRAE Handbook on Fundamentals, American Society of Heating, Refrigerating, and Air-Conditioning Engineers, Inc., New York, 1972.

8. Thermophysical Properties of Refrigerants, pp. 145-150, American Soclety of Heating, Refrigerating, and Alr-Conditioning Engineers, Inc., New York, 1973.

9. Thermophysical Properties of Refrigerants, pp. 131-150, American Soclety of Heating, Refrigerating, and Air-Conditioning Engineers, Inc., New York, 1969.

10. W. H. McAdams, Heat Thansmission, 3d ed., McGraw-H111, New York, 1954.

11. A. P. Colburn, "A Method of Correlating Forced Convection Heat Transfer Data and a Comparison with Fluid Friction," Trans. $A m$. Inst. Chem. Eng. 29, 174 (1.933).

12. E. N. Sleder and C. E. Tate, "Heat Transfer and Pressure Drop of Liquids in Tubes," Ind. Eng. Chem. 28, 1429 (1936).

13. R. Gregorig, "An Analysis of Film Condensation on Wavy Surfaces Including Surface Tension Effects," Z. Angew. Math. Phy6. 5, 36 (1954). 
七

.

$\therefore$

. 
Appendix A

SAMPLES OF DATA REDUCTION

\section{A.1 Physical Properties for $R-11$}

All property data for $\mathrm{R}-11$ used in the data reduction were taken from American Society of Heating, Refrigerating, and Air-Conditioning Engineers (ASHRAE) handbooks. ${ }^{7-9}$ The accuracy of thermophysical properties is discussed in Ref. 8 .

\section{A.2 Fluted Tube}

A sample of the experimental data required for computing the composite condensing film coefficient for a given vapor temperature and heat flux is listed in Table A.1. Data are for $\mathrm{R}-11$ condensing on Tube I (60 external corrugations and smooth inside wa11). Experimental run $R-11-001 \mathrm{~L}$ is used to demonstrate the data reduction procedure, and the series of runs R-11-001 I through R-11-004 L are used to demonstrate the Wilson-plot technique.

The measured pressure ( $P$ ) of the vapor should agree with the saturation pressure $\left(P_{8 a t}\right)$ of $R-11$ at the vapor temperature $\left(T_{v}\right)$, assuming that no contaminants or superheat are present. In this study, the pressure data for $R-11$ from $A S H R A E^{7-9}$ were fitted as polynomial functions of temperature for the range of 70 to $120^{\circ} \mathrm{F}$, resulting in the following equations:

$$
\begin{aligned}
& P_{\text {6at }}=1.74693+0.105969\left(T_{v}\right)+ 2.5 \times 10^{-4}\left(T_{v}\right)^{2} \\
&+8.61134 \times 10^{-6}\left(T_{v}\right)^{3} \\
& P_{c}=98.1541 \times 7.3367 \times 10^{-2}\left(T_{c}\right)-6.08035 \times 10^{-5}\left(T_{c}\right)^{2} \\
& h_{f g}=83.6357-7.53477 \times 10^{-2}\left(T_{v}\right) \\
&-8.61023 \times 10^{-5}\left(T_{v}\right)^{2}
\end{aligned}
$$


Table A.1. Sample of experimental data $-R-11$ condensing on Tube $L$

\begin{tabular}{|c|c|c|c|c|c|c|c|c|}
\hline \multirow[b]{2}{*}{ Run No. } & \multicolumn{2}{|c|}{$\begin{array}{l}\text { Vapor feed to } \\
\text { test section }\end{array}$} & \multicolumn{2}{|c|}{ Condensate } & \multicolumn{4}{|c|}{ Primary cooling water through test section } \\
\hline & $\begin{array}{c}\text { Temperature, } a \\
\left(T_{\mathbf{v}}\right. \\
\left({ }^{\circ}\right)\end{array}$ & $\begin{array}{c}\text { Pressure, } \\
\text { P } \\
\text { (psia) }\end{array}$ & $\begin{array}{c}\text { Flow rate, }{ }^{c} \\
F_{c} \\
(\mathrm{gpm})\end{array}$ & $\begin{array}{c}\text { Temperature, }{ }^{a} \\
T_{c}(\circ)\end{array}$ & $\begin{array}{c}\text { Flow rate, } \\
F_{W} \\
(\mathrm{gpm})\end{array}$ & $\begin{array}{l}\text { Inlet } \\
\text { temperature }{ }^{a} \\
\mathrm{~T}_{\mathrm{w}} \text {, in } \\
\left({ }^{\circ} \mathrm{F}\right)\end{array}$ & $\begin{array}{l}\text { Outlet } \\
\text { temperature, } a \\
\mathrm{~T}_{w, \text { out }} \\
\left({ }^{\circ} \mathrm{F}\right)\end{array}$ & $\begin{array}{c}\text { Temperature } \\
\text { difference, }{ }_{a, b} \\
\Delta \mathrm{T}_{w} \\
\left({ }^{\circ} \mathrm{F}\right)\end{array}$ \\
\hline$R-11-001 \quad L$ & 94.08 & 21.0 & 0.1419 & 91.27 & 22.0 & 83.41 & 84.14 & 0.70 \\
\hline$R-11-002 L$ & 97.35 & 22.2 & 0.1410 & 94.44 & 7.6 & 83.08 & 85.13 & 2.03 \\
\hline$R-11-003 \mathrm{~L}$ & 99.65 & 23.2 & 0.1418 & 96.50 & 5.2 & 82.91 & 85.86 & 2.95 \\
\hline$R-11-004 \mathrm{~L}$ & 104.68 & 25.2 & 0.1417 & 101.05 & 3.0 & 82.64 & 87.61 & 4.97 \\
\hline
\end{tabular}

Measured by thermistors (The rmometrics Part No. S-10-4 Wire).

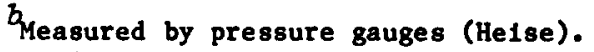

Measured by turbine flow transducer (Flow Technology, Model FTM-A15-LJS).

Measured by one of two rotameters (F1sher and Porter Company and Brooks Rotameter Company).

${ }^{e}$ Corrected for temperature of $f$ set and temperature rise from heat generated by friction between fluid and tube wall. 
From Eq. (A.1), the saturation pressure ( $P_{\text {sat }}$ ) corresponding to a temperature of $94.08^{\circ} \mathrm{F}$ is $21.1 \mathrm{psia}$, which agrees we11 $(0.5 \%)$ within the experimental accuracy of the instruments to the measured pressure $(P)$ of 21.0 psia for run R-11-001 L. This agreement also indicates the absence of appreciable amounts of noncondensables in the condenser during operation. The quantities $p_{c}$ and $h_{f g}$ are used later for calculating the heat transfer rates in the condenser from the condensate flow.

The heat transfer rate or heat load in the condenser can be computed by two separate sets of measurements - one on the refrigerant side and one on the water side. To calculate the heat transfer rate from the refrigerant side, condensate flow rate $\left(F_{c}\right)$ requires the latent heat $\left(h_{f g}\right)$ of $R-11$ at the vapor temperature $\left(T_{v}\right)$ and the density of liquid $R-11$ at the condensate temperature $\left(T_{c}\right)$ near the condensate flow measuring station. From Eqs. (A.2) and (A.3) for

$$
\begin{aligned}
& T_{c}=91.27^{\circ} \mathrm{F}+\rho_{c}=90.951 \mathrm{~b} / \mathrm{ft}^{3}, \\
& T_{v}=94.08^{\circ} \mathrm{F}+h_{f_{g}}=75.78 \mathrm{Btu} / 1 \mathrm{~b} .
\end{aligned}
$$

The heat transfer rate can then be calculated from Eq. (4.3), presented in the main text, where the condensate flow rate is given by

$$
\dot{\mathrm{m}}_{\mathrm{c}}=\mathrm{F}_{\mathrm{c}} \rho_{\mathrm{c}} \text {, }
$$

so that

$$
\begin{aligned}
Q_{c} & =F_{c} \rho_{c}^{h_{f g}} \\
& =(0.1419 \mathrm{gpm})\left(90.95 \mathrm{lb} / \mathrm{ft}^{3}\right)(75.78 \mathrm{Btu} / 1 \mathrm{~b}) \\
\times\left(1 \mathrm{ft}^{3} / 7.481 \mathrm{gal}\right)(60 \mathrm{~min} / \mathrm{h}) & \\
& =7843 \mathrm{Btu} / \mathrm{h} .
\end{aligned}
$$

The heat transfer rate computed from the primary cooling water is given by:

$$
Q_{w}=F_{w} P_{w} C_{P_{w}} \Delta T_{w}
$$

where $F_{w}$ and $\Delta T_{w}$ are the volume flow rate and temperature rise of the 
primary cooling water, respectively. The term $C_{p_{w}}$ is the average heat capacity of the primary cooling water, and $\rho_{w}$ is the average density of the primary cooling water; both $C_{P_{w}}$ and $p_{w}$ are calculated at the average temperature of the primary water $T_{w, a v g^{*}}$ In this particular example, the change in water temperature $\Delta \mathrm{T}_{\mathrm{w}}$ is so small that the variation in properties is insignificant. The average temperature of the primary cooling water is the average of the inlet temperature $\left(83.41^{\circ} \mathrm{F}\right)$ and the outlet temperature $\left(84.14^{\circ} \mathrm{F}\right)$. The properties for water at an average temperature of $83.78^{\circ} \mathrm{F}$ are $\rho_{\mathrm{w}}=62.291 \mathrm{~b} / \mathrm{ft}^{3}$, and $\mathrm{c}_{\mathrm{P}_{\mathrm{w}}}=1.0 \mathrm{Btu} / 1 \mathrm{~b} \mathrm{~m}{ }^{\circ} \mathrm{F}$, so that, from Eq. (A.5), the heat transfer rate for run R-11-001 I becomes

$$
\begin{aligned}
Q_{w}= & (22.0 \mathrm{gpm})\left(62.291 \mathrm{~b}_{\mathrm{m}} / \mathrm{ft}^{3}\right)\left(1 \mathrm{Btu} / 1 \mathrm{~b}_{\mathrm{m}}{ }^{\circ} \mathrm{F}\right)\left(0.70^{\circ} \mathrm{F}\right) \\
& \times\left(1 \mathrm{ft}^{3} / 7.481 \mathrm{gal}\right)(60 \mathrm{~min} / \mathrm{h}) \\
= & 7694 \mathrm{Btu} / \mathrm{h} .
\end{aligned}
$$

The percent of difference between the two heat loads is given by:

$$
\begin{aligned}
\frac{\Delta Q}{Q} \times 100 & =\frac{\left(Q_{c}-Q_{w}\right)}{Q_{c}} \times 100=\frac{(7843-7694)}{7843} \times 100 \\
\Delta \% & =1.90
\end{aligned}
$$

This value illustrates the agreement between the two different methods. The overall condensing heat transfer coefficient can be computed from Eq. (4.1) with either $Q_{c}$ or $Q_{w}$. However, the heat rate from the condensate flow $\left(Q_{c}\right)$ is used in the calculation because it is considered the more accurate of the two. The overall mean temperature difference $(\overline{\Delta T})$ is given by Eq. $(4.2)$ :

$$
\overline{\Delta T}=T_{v}-\left(T_{w, \text { in }}+T_{w, \text { out }}\right) / 2
$$

Therefore, with the information for run $\mathrm{R}-11-001 \mathrm{~L}$,

$$
\overline{\Delta T}=94.08^{\circ} \mathrm{F}-\left(83.41^{\circ} \mathrm{F}+84.14^{\circ} \mathrm{F}\right) / 2=10.30^{\circ} \mathrm{F}
$$


The outside surface area $\left(A_{0}\right)$ of Tube $L$ is listed in Table 2.1 as 0.1397 $\mathrm{m}^{2}\left(1.504 \mathrm{ft}^{2}\right)$. Applying $\mathrm{Eq}$. (4.1) and using the data from run R-11-001 L,

$$
J=\frac{Q_{c}}{A_{0} \overline{\Delta T}}=\frac{7843 \mathrm{Btu} / \mathrm{h}}{\left(1.504 \mathrm{ft}^{2}\right)\left(10.30^{\circ} \mathrm{F}\right)}=506 \mathrm{Btu} / \mathrm{h} \cdot \mathrm{ft}^{2}{ }^{\circ} \mathrm{F}
$$

The same calculations illustrated for run R-11-001 L can be used for the other three runs in Table A.1. The results of the calculations for all four runs are shown in Table A.2. The four heat rates can be averaged to obtain an average heat load for the series of runs so that

$$
\begin{aligned}
& Q_{c, a v g}=7747 \mathrm{Btu} / \mathrm{h}, \\
& Q_{\mathrm{w}, \text { avg }}=7607 \mathrm{Btu} / \mathrm{h}
\end{aligned}
$$

Water velocities (v) in Table 4.2 are calculated from

$$
v=F_{w} / A_{c} \text {, }
$$

where $A_{c}$ is the cross-sectional flow area. During experimental tests with Tube $\mathrm{L}$, a $0.5-\mathrm{in}$. diam solid rod was inserted through the tube center as noted in Sect. 2.2. For Tube $L$, the cross-sectional flow area is

$$
A_{c}=\frac{\pi}{4}\left(D_{i}^{2}-D_{r}^{2}\right)
$$

where $D_{i}$ is the inside diameter of the test tube and $D_{r}$ is the outside diameter of the solid rod. Because Tube $L$ has an inside diameter $\left(D_{i}\right)$ of 0.87 in.

$$
\begin{aligned}
A_{c} & =\frac{\pi}{4}\left[\left(\frac{0.87}{12}\right)^{2}-\left(\frac{0.50}{12}\right)^{2}\right] \\
& =0.002765 \mathrm{ft}^{2}
\end{aligned}
$$


Table A.2. Sample Information for the Wilson plot $-\mathrm{R}-11$ condensing on Tube $L$

\begin{tabular}{|c|c|c|c|c|c|c|c|c|}
\hline \multirow[b]{2}{*}{ Run No. } & \multicolumn{3}{|c|}{ Condenser heat load } & \multirow{2}{*}{$\begin{array}{c}\text { Overall mean } \\
\text { temperature } \\
\text { difference, } \\
\frac{\mathrm{dT}}{\left({ }^{\circ} \mathrm{F}\right)}\end{array}$} & \multirow{2}{*}{$\begin{array}{c}\text { Primary cooling } \\
\text { water velocity, v } \\
\text { (ft/s) }\end{array}$} & \multirow{2}{*}{$1 / v^{0.8}$} & \multirow{2}{*}{$\begin{array}{c}\text { Overall } \\
\text { coefficlent, } \mathrm{U} \\
\left(\mathrm{Btu} / \mathrm{h} \cdot \mathrm{ft}^{2} \cdot{ }^{\circ} \mathrm{F}\right)\end{array}$} & \multirow{2}{*}{$\left(h \cdot f t^{\frac{1}{2} \cdot U} \cdot F / B t u\right)$} \\
\hline & $\begin{array}{c}Q_{c}^{\alpha} \\
(B t u / h)\end{array}$ & $\begin{array}{c}Q_{W}^{b} \\
(B t u / h)\end{array}$ & $\Delta \%$ & & & & & \\
\hline$R-11-001 \mathrm{~L}$ & 7843 & 7694 & 1.9 & 10.30 & 17.7 & 0.1004 & 506 & $1.98 \times 10^{-3}$ \\
\hline $\mathrm{R}-11-002 \mathrm{~L}$ & 7741 & 7716 & 0.3 & 13.24 & 6.1 & 0.2354 & 389 & $2.57 \times 10^{-3}$ \\
\hline$R-11-003 \mathrm{~L}$ & 7746 & 7643 & 1.3 & 15.26 & 4.2 & 0.3172 & 337 & $2.98 \times 10^{-3}$ \\
\hline$R-11-004 \mathrm{~L}$ & 7660 & 7436 & 2.9 & 19.55 & 2.4 & 0.4964 & 260 & $3.85 \times 10^{-3}$ \\
\hline
\end{tabular}

${ }^{a}$ Calculated from condensate flow.

${ }^{b}$ Calculated fron temperature rise and flow of the primary cooling water.

${ }^{c}$ Between condensing vapor and primary cooling flow. 
and the water velocity for run $\mathrm{R}-11-001 \mathrm{~L}$ is

$$
\begin{aligned}
v & =(22.0 \mathrm{gpm}) \frac{1 \mathrm{ft}^{3}}{7.481 \mathrm{gal}} \cdot \frac{1 \mathrm{~min}}{60 \mathrm{~s}} \cdot \frac{1}{0.002765 \mathrm{ft}^{2}} \\
& =17.7 \mathrm{ft} / \mathrm{s} .
\end{aligned}
$$

To generate the Wilson plot, the reciprocal of the overall coefficient must be taken and the water velocity must be raised to the negative 0.8 power. For example, with the values for run $\mathrm{R}-11-001 \mathrm{~L}$,

$$
\frac{1}{v^{0.8}}=(1 / 17.7 \mathrm{ft} / \mathrm{s})^{0.8}=0.1004
$$

and

$$
\frac{1}{\bar{U}}=\left(1 / 506 \mathrm{Btu} / \mathrm{h} \cdot \mathrm{ft}^{2} \cdot{ }^{\circ} \mathrm{F}\right)=1.98 \times 10^{-3} \frac{\mathrm{h} \cdot \mathrm{ft}^{2} \cdot{ }^{\circ} \mathrm{F}}{\mathrm{Btu}}
$$

The values for $\left(v^{-0.8}\right)$ and $(1 / 0)$ are given in Table A.2 and were used to construct the wilson plot shown in Fig. A.1. The data points shown in Fig. A.1 were fitted by a least squares method of the first order to determine the best linear fit to satisfy the following relationship:

$$
\frac{1}{U}=a_{0}+a_{1} v^{-0.8}
$$

where $a_{1}$ is the slope of the straight line and $a_{0}$ is the $y$-intercept. The reciprocal ( $1 / a_{0}$ or $\left.h_{c}\right)$ gives the composite heat transfer coefficient of the condensing film and tube wall.

For this particular run series, the values $a_{0}$ and $h_{c}$ are:

$$
\begin{aligned}
& a_{0}=1.48 \times 10^{-3} \mathrm{~h} \cdot \mathrm{ft}^{2} \cdot{ }^{\circ} \mathrm{F} / \mathrm{Btu}, \\
& \mathrm{h}_{c}=677 \mathrm{Btu} / \mathrm{h} \cdot \mathrm{ft}^{2} \cdot{ }^{\circ} \mathrm{F} .
\end{aligned}
$$

The data show good linearity and allow extrapolation, with some confidence, to infinite water velocity (zero water-side resistance) at the plot y-intercept (Fig. A.1). 


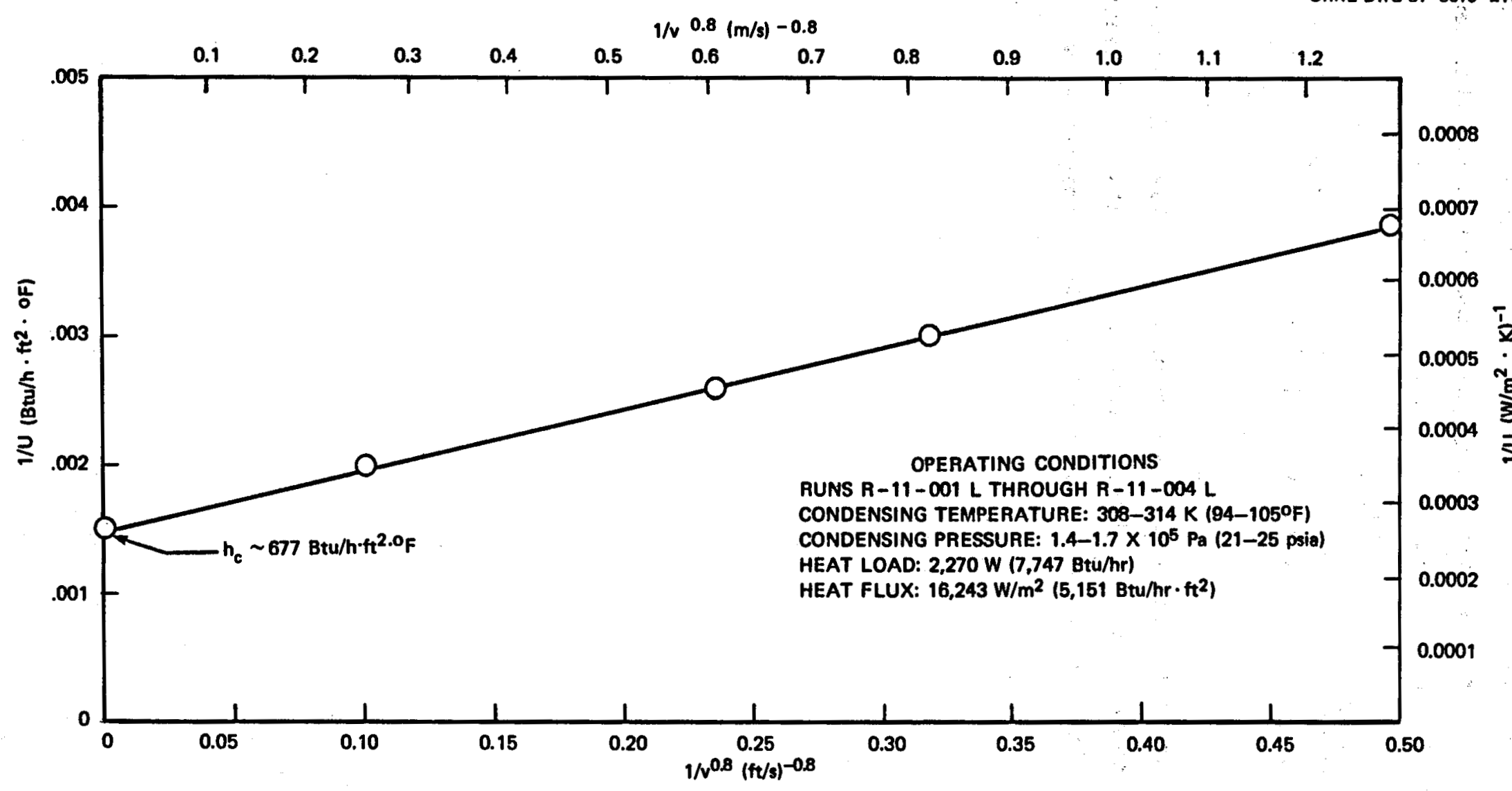

F1g. A.1. Wilson-plot for $R-11$ condensing outside fluted Tube $L-$ runs $R-11-001$ L to $R-11-004 \mathrm{~L}$. 
The corresponding composite temperature difference is calculated using Eq. (4.9). Because the average heat load value for this series of runs is $\sim 7747 \mathrm{Btu} / \mathrm{h}$, then from $\mathrm{Eq} .(4.9)$ :

$$
\Delta T_{c}=\frac{Q_{c, a v g}}{h_{c} A_{0}}=\frac{(7747 \mathrm{Btu} / \mathrm{h})}{\left(677 \mathrm{Btu} / \mathrm{h} \cdot \mathrm{ft}^{2} \cdot{ }^{\circ} \mathrm{F}\right)\left(1.504 \mathrm{ft}^{2}\right)}=7.6{ }^{\circ} \mathrm{F}
$$

The computations outlined in this appendix were followed in reducing all of the experimental data. These Wilson-plot results are presented in graphic and tabular form, Sect. 5.0 and Appendix B, respectively. 


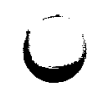

t 


\section{Appendix B}

\section{WILSON-PLOT RESULTS}

Wilson-plot results from condensation experiments performed on single, vertical tubes in this study are summarized herein. Table B.l (from Ref. 3) is presented for Tube $A$ as a baseline comparison with the other tested tubes (Tables B.2 through B.12). The condenser heat load was taken as the average heat load based on the condensate flow $\left(Q_{c, a v g}\right)$ for a series of runs (see Appendix A for an example). Individual runs are documented in Appendix C. 
Table B.1. Summary of experimental conditions and results from Wilson plots for R-11 condensing on vertical Tube A

\begin{tabular}{|c|c|c|c|c|c|c|c|}
\hline \multirow{2}{*}{ Serles of runs } & \multicolumn{3}{|c|}{$\begin{array}{l}\text { Condenser heat load } \\
{[\mathrm{H}(\mathrm{Btu} / \mathrm{h})]}\end{array}$} & \multirow{2}{*}{$\begin{array}{c}\text { Difference } \\
(\%)\end{array}$} & \multirow{2}{*}{$\begin{array}{c}\text { Vapor temperature range } \\
{\left[K\left({ }^{\circ} \mathrm{F}\right)\right]}\end{array}$} & \multirow{2}{*}{$\begin{array}{l}\text { Condensing } \\
\text { temperature } \\
\text { difference } \\
{\left[\mathrm{K}\left({ }^{\circ} \mathrm{F}\right)\right]}\end{array}$} & \multirow{2}{*}{$\begin{array}{c}\text { Condensing heat } \\
\text { transfer coeffictent } \\
{\left[\mathrm{W} / \mathrm{m}^{2} \cdot \mathrm{K}\right.} \\
\left(\mathrm{Btu} / \mathrm{h} \cdot \mathrm{ft}^{2 \cdot \bullet \bullet \mathrm{F})]}\right.\end{array}$} \\
\hline & $Q_{c}$ & & $Q_{w}$ & & & & \\
\hline$R-11-037 A$ to $040 A$ & $1271(4336)$ & 1286 & $(4388)$ & -1.2 & $315.7-318.5(108.9-113.9)$ & $14.1 \cdot(25.4)$ & $923.3(162.8)$ \\
\hline$R-11-047 A$ to $044 A$ & $774(2642)$ & 797. & $(2722)$ & -3.0 & $309.9-311.3:(98.4-100.9)$ & $8.1:(14.6)$ & $981.8(173.2)$ \\
\hline$R-11-045 A$ to $048 A$ & $926(3161)$ & 947 & $(3231)$ & -2.2 & $311.5-313.3(101.3-104.6)$ & $10.0(17.9)$ & $955.1(168.4)$ \\
\hline$R-11-049 A$ to $052 A$ & $1638(5589)$ & 1644 & $(5611)$ & -0.4 & $319.3-323.1(115.3-122.1)$ & $18.5(33.3)$ & $909.5 \cdot(160.4)$ \\
\hline$R-11-053 A$ to $056 A$ & $1874(6394)$ & 1892 & $(6457)$ & -1.0 & $322.4-327.1(120.9-129.3)$ & $21.6(38.8)$ & $891.9(157.3)$ \\
\hline$R-1: 1-057 A$ to $060 A$ & $2219(7572)$ & 2200 & $(7507)$ & -0.9 & $325.3-330.8(126.2-136.0)$ & $25.2(45.3)$ & $905.6(159.7)$ \\
\hline$R-11-061 A$ to $064 A$ & $1112(3795)$ & 1145 & (3908) & -3.0 & $313.3-315.6(104.6-108.7)$ & $12.2 \cdot(22.0)$ & $935.2(164.9)$ \\
\hline$R-11-065 A$ to $068 A$ & $2066(7051)$ & 2063 & $(7040)$ & -0.2 & $322.1-327.5(120.4-130.1)$ & $23.8(42.9)$ & $889.6(156.9)$ \\
\hline$R-11-069 A$ to $072 A$ & $1495(5101)$ & 1531 & $(5226)$ & -2.4 & $316.3-320.7(109.9-117.8)$ & $16.9(30.5)$ & $906.6(159.9)$ \\
\hline$R-11-073 A$ to $076 A$ & $2402(8197)$ & 2425 & $(8276)$ & -1.0 & $323.1-329.1(122.2-132.9)$ & $27.4(49.4)$ & $899.3(1.58 .6)$ \\
\hline R-11-077A to 080A & $583(1989)$ & 605 & (2064) & -3.8 & $307.7-308.8(94.5-96.4)$ & $6.2(11.2)$ & $958.6(169.1)$ \\
\hline
\end{tabular}


Table B.2. Summary of experimental conditions and results from W11son plots for $R-11$ condensing on vertical Tube $A-1$

\begin{tabular}{|c|c|c|c|c|c|c|}
\hline \multirow{2}{*}{ Series of runs } & \multicolumn{2}{|c|}{$\begin{array}{l}\text { Condenser heat load } \\
{[\mathrm{W}(\mathrm{Btu} / \mathrm{h})]}\end{array}$} & \multirow{2}{*}{$\begin{array}{c}\text { Difference } \\
(z)\end{array}$} & \multirow{2}{*}{$\begin{array}{l}\text { Vapor temperature range } \\
{\left[K\left({ }^{\circ} \mathrm{F}\right)\right]}\end{array}$} & \multirow{2}{*}{$\begin{array}{l}\text { Condensing } \\
\text { temperature } \\
\text { difference } \\
{\left[\mathrm{K}\left({ }^{\circ} \mathrm{F}\right)\right]}\end{array}$} & \multirow{2}{*}{$\begin{array}{c}\text { Condensing heat } \\
\text { transfer coefficient } \\
{\left[\mathrm{W} / \mathrm{m}^{2} \cdot \mathrm{K}\right.} \\
\left.\left(\mathrm{Btu} / \mathrm{h} \cdot \mathrm{ft}^{2} \cdot{ }^{\circ} \mathrm{F}\right)\right]\end{array}$} \\
\hline & $\therefore \mathbf{Q}_{\mathbf{c}}$ & $\mathbf{Q}_{\mathbf{W}}$ & & & & \\
\hline$R-11-001$ to $004 \mathrm{~A}-1$ & $938(3203)$ & $922(3148)$ & 1.7 & $310.5-313.0(99.2-103.7)$ & $8.4(15.1)$ & $1151.2(203.0)$ \\
\hline$R-11-005$ to $008 \dot{A}-1$ & $1972(6729)$ & $-1939(6618)$ & 1.6 & $313.7-319.4(104.9-115.3)$ & $19.8(35.7)$ & $1021.9(180.2)$ \\
\hline$R-11-009$ to $012 \mathrm{~A}-1$ & $1388(4738)$ & $1360(4643)$ & .2 .0 & $315.5-320.1(108.3-116.5)$ & $13.3 .(24.0)$ & $106.9 .6(188.6)$ \\
\hline$R-11-013$ to $016 \mathrm{~A}-1$ & 700. (2390) & $684(2335)$ & 2.3 & $315.1-316.2(107.6-10.9 .5)$ & $5.7(10.3)$ & $1255.7(221.5)$ \\
\hline$R-11-017$ to $020 \mathrm{~A}-1$ & $1581(5398)$ & $1558(5316)$ & 1.5 & $314.8-320.3(106.9-116.8)$ & $15.6(28.0)$ & $1044.2(184.2)$ \\
\hline$R-11-021$ to $024 \mathrm{~A}-1$ & $1185(4043)$ & $1176(4014)$ & 0.7 & $314.5-317.1(106.4-111.2)$ & $11.1 \cdot(20.0)$ & $1095.2(193.2)$ \\
\hline$R-11-025$ to $028 \mathrm{~A}-1$ & $1802(6149)$. & $1782(6083)$ & 1.1 & $313.7-319.6(105.0-115.6)$ & $18.2(32.8)$ & $1016.5(179.3)$ \\
\hline$R-11-029$ to $032 \mathrm{~A}-1$ & $2188(7469)$ & $2129(7265)$ & 2.7 & $317.0-323.9(111.0-123.3)$ & $22.3(40.2)$ & $1006.3(177.5)$ \\
\hline
\end{tabular}


Table B.3. Summary of experimental conditions and results from W1lson plots for R-11 condensing on vertical Tube $L$

\begin{tabular}{|c|c|c|c|c|c|c|}
\hline \multirow{2}{*}{ Series of runs } & \multicolumn{2}{|c|}{$\begin{array}{c}\text { Condenser heat load } \\
{[\mathrm{W}(\mathrm{Btu} / \mathrm{h})]}\end{array}$} & \multirow{2}{*}{$\begin{array}{c}\text { Difference } \\
(\%)\end{array}$} & \multirow{2}{*}{\multicolumn{2}{|c|}{$\begin{array}{cr} & \text { Condensing } \\
\text { Vapor temperature range } & \text { temperature } \\
{\left[K\left({ }^{\circ} \mathrm{F}\right)\right]} & \text { difference } \\
& {\left[\mathrm{K}\left({ }^{\circ} \mathrm{F}\right)\right]}\end{array}$}} & \multirow{2}{*}{$\begin{array}{l}\text { Condensing heat } \\
\text { transfer coefficlent } \\
{\left[\mathrm{W} / \mathrm{m}^{2} \cdot \mathrm{K}\right.} \\
\left(\mathrm{Btu} / \mathrm{h} \cdot \mathrm{ft}^{2 \cdot \bullet \mathrm{F})]}\right.\end{array}$} \\
\hline & $Q_{c}$ & $Q_{w}$ & & & & \\
\hline$R-11-001 \cdot L$ to $004 \mathrm{~L}$ & $2270(7747)$ & $2229(7607)$ & 1.8 & $307.6-313.5(94.1-104.7)$ & $4.2(7.6)$ & $3837.1(676.7)$ \\
\hline $\mathrm{R}-11-005 \mathrm{~L}$ to $008 \mathrm{~L}$ & $4077(13913)$ & $4026(13740)$ & 1.3 & $306.7-319.0(92.3-114.6)$ & $10.5(18.9)$ & $2774.4(489.3)$ \\
\hline $\mathrm{R}-11-009 \mathrm{~L}$ to $012 \mathrm{~L}$ & $1123(3831)$ & $1108(3783)$ & 1.3 & $309.4-311.7(97.3-101.4)$ & $1.7(3.0)$ & $4846.7(854.8)$ \\
\hline $\mathrm{R}-11-013 \mathrm{~L}$ to $016 \mathrm{~L}$ & $1119(3818)$ & $1125(3841)$ & -0.6 & $309.3-311.9(97.1-101.7)$ & $1.7(3.0)$ & $4769.1(841.12)$ \\
\hline $\mathrm{R}-11-017 \mathrm{~L}$ to $020 \mathrm{~L}$ & $1597 \cdot(5449)$ & $1607(5484)$ & -0.7 & $308.4-312.2(95.4-102.3)$ & $2.8(5.0)$ & $4141.0(730.3)$ \\
\hline $\mathrm{R}-11-021 \mathrm{~L}$ to $023 \mathrm{~L}$ & $2956(10089)$ & 2918 (9959) & 1.3 & $307.8-312(94.4-102.0)$ & $6.5(11.6)$ & $3269.9(576.7)$ \\
\hline $\mathrm{R}-11-024 \mathrm{~L}$ to $027 \mathrm{~L}$ & $815(2782)$ & $843(2876)$ & -3.4 & $309.7-311.9(97.7-99.9)$ & $1.1(2.0)$ & $5350.5(943.6)$ \\
\hline $\mathrm{R}-11-028 \mathrm{~L}$ to $031 \mathrm{~L}$ & $1270(4334)$ & $1254(4281)$ & 1.2 & $309.0-311.6(96.5-101.2)$ & $2.0(3.7)$ & $4444.1(783.8)$ \\
\hline $\mathrm{R}-11-032 \mathrm{~L}$ to $035 \mathrm{~L}$ & $2551(8705)$ & $2521(8604)$ & 1.2 & $307.7-314.6(94.1-106.6)$ & $5.0(9.0)$ & $3634.1(640.9)$ \\
\hline $\mathrm{R}-11-036 \mathrm{~L}$ to $039 \mathrm{~L}$ & $1955(6672)$ & $1944(6635)$ & 0.6 & $308.4-313.4(95.4-104.4)$ & $3.5(6.3)$ & $4001.1(705.7)$ \\
\hline$R-11-040 \mathrm{~L}$ to $043 \mathrm{~L}$ & $3430(11707)$ & $3367(11492)$ & 1.8 & $307.9-317.7(94.5-112.3)$ & $7.8(14.1)$ & $3136.2(553.1)$ \\
\hline$R-11-044$ L to $047 \mathrm{~L}$ & $3755(12817)$ & $3675(12543)$ & 2.1 & $306.5-318.1(92.0-112.8)$ & $8.9(16.0)$ & $3012.4(531.3)$ \\
\hline
\end{tabular}


Table B.4. Summary of experimental conditions and results from Wilson plots for R-11 condensing on vertical Tube $L-1$

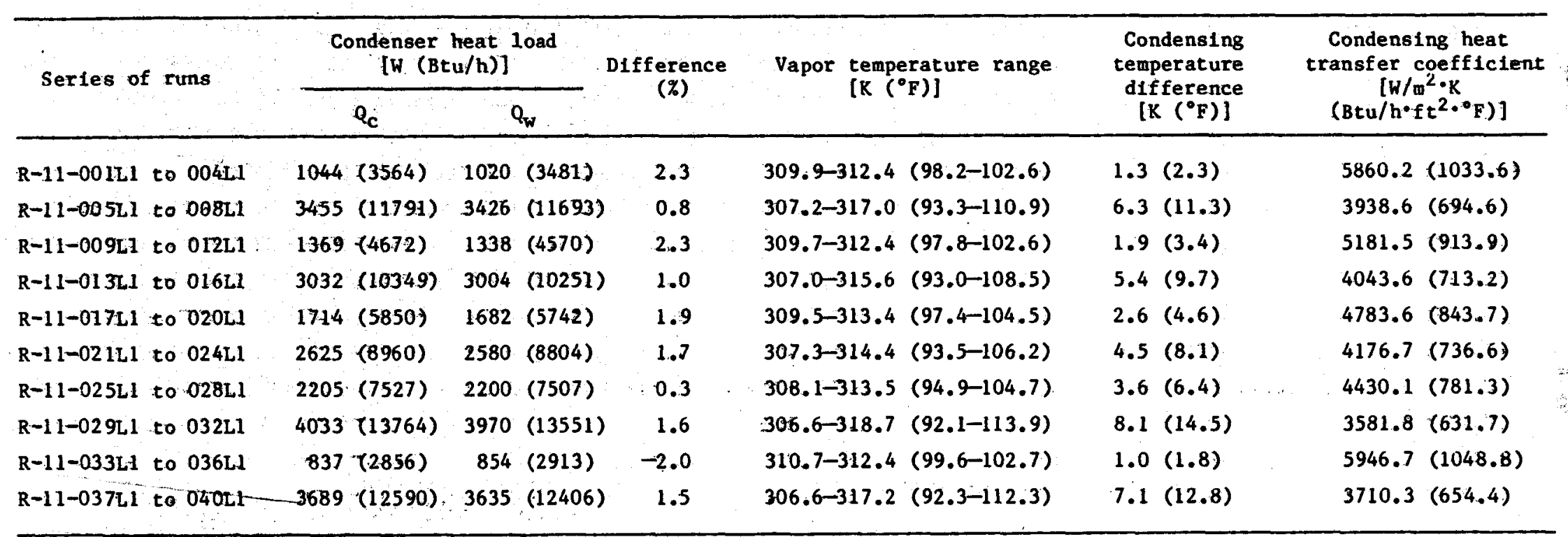


Table B.5. Summary of experimental conditions and results from W1lson plots, for R-11 condensing on vertical Tube $L-3$

\begin{tabular}{|c|c|c|c|c|c|c|c|}
\hline \multirow{2}{*}{ Series of } & \multirow{2}{*}{ runs } & \multicolumn{2}{|c|}{$\begin{array}{c}\text { Condenser heat load } \\
{[\mathrm{W}(\mathrm{Btu} / \mathrm{h})]}\end{array}$} & \multirow{2}{*}{$\begin{array}{l}\text { Difference } \\
(x)\end{array}$} & \multirow{2}{*}{$\begin{array}{c}\text { Vapor temperature range } \\
{\left[K\left({ }^{\circ} F\right)\right]}\end{array}$} & \multirow{2}{*}{$\begin{array}{c}\text { Condensing } \\
\text { temperature } \\
\text { difference } \\
{\left[\mathrm{K}\left({ }^{\circ} \mathrm{F}\right)\right]}\end{array}$} & \multirow{2}{*}{$\begin{array}{c}\text { Condensing heat } \\
\text { transfer coèfficlent } \\
{[\mathrm{W} / \mathrm{m} \cdot \mathrm{K}} \\
\left.\left(\mathrm{Btu} / \mathrm{h} \cdot \mathrm{ft} \cdot{ }^{\circ} \mathrm{F}\right)\right]\end{array}$} \\
\hline & & $\mathbf{Q}_{\mathbf{c}}$ & $Q_{w}$ & & & & \\
\hline$R-11-001 \quad L 3$ & to $004 \mathrm{L3}$ & $2169(7303)$ & $2148(7332)$ & 1.0 & $308.0-313.7(94.8-105.1)$ & $3.3(5.9)$ & $4761.6(839.8)$ \\
\hline$R-11-005 \mathrm{~L} 3$ & to $008 \mathrm{~L} 3$ & $1305(4455)$ & $1284(4380)$ & 1.7 & $309.6-312.0(97.6-101.9)$ & $1.7(3.0)$ & $5655.5(997.24$ \\
\hline$R-11-009 L 3$ & to $012 \mathrm{~L} 3$ & $4040(13788)$ & $3992(13623)$ & 1.2 & $306.7-318.5(92.4-113.6)$ & $7.5(13.5)$ & $3854.0(679.7)$ \\
\hline$R-11-013$ L3 & to $016 \mathrm{~L} 3$ & 2695 (9199) & 2647 (9035) & 1.8 & $307.4-314.4(93.6-106.3)$ & $4.4(7.9)$ & $4413.8 \cdot(778.5)$ \\
\hline$R-11-017 \quad L 3$ & to $020 \mathrm{L3}$ & $1068(3644)$ & $1047(3573)$ & 2.0 & $309.8-312.2(98.0-102.3)$ & $1.3(2.3)$ & $5971.4(1053.2)$ \\
\hline$R-11-021 \quad L 3$ & to $024 \mathrm{L3}$ & $3483 \cdot(11887)$ & $3402(11611)$ & 2.3 & $307.3-317.2(93.4-111.2)$ & $6.1(11.0)$ & $4081.0(719.8)$ \\
\hline$R-11-025 L 3$ & to $028 \mathrm{L3}$ & $1797(6132)$ & $1774(6053)$ & 1.3 & $305.2-313.7(96.8-105.0)$ & $2.6(4.6)$ & $5039.2(888.8)$ \\
\hline$R-11-029$ L3 & to 032 L3 & $3102(10589)$ & $3054(10424)$ & 1.6 & $306.8-315.5(92.6-108.2)$ & $5.2(9.4)$ & $4247.8(749.2)$ \\
\hline$R-11-03323$ & to $036 \mathrm{L3}$ & $852(2909)$ & $853(2911)$ & -0.1 & $310.1-312.0(98.6-101.8)$ & $0.9(1.67$ & $6560.6(1157.1)$ \\
\hline$R-11-037 \quad L 3$ & to $040 \mathrm{~L} 3$ & $3720(12696)$ & $3646(12443)$ & 2.0 & $306.8-317.5(92.6-111.9)$ & $6.7(12.0)$ & $3985.2(702.9)$ \\
\hline
\end{tabular}


Table B.6. Sumary of experimental conditions and results from wilson plots for $R-11$ condensing on vertical Tube $M$

\begin{tabular}{|c|c|c|c|c|c|c|c|}
\hline \multirow{2}{*}{$\begin{array}{c}\text { Series of runs } \\
\text { a }\end{array}$} & \multicolumn{3}{|c|}{$\begin{array}{l}\text { Condenser heat load } \\
{[\mathrm{H}(\mathrm{Btu} / \mathrm{h})]}\end{array}$} & \multirow{2}{*}{$\begin{array}{c}\text { Difference } \\
(x)\end{array}$} & \multirow{2}{*}{$\begin{array}{l}\text { Vapor temperature range } \\
{\left[\mathrm{K}\left({ }^{\circ} \mathrm{F}\right)\right]}\end{array}$} & \multirow{2}{*}{$\begin{array}{l}\text { Condensing } \\
\text { temperature } \\
\text { difference } \\
{\left[K\left({ }^{\circ} \mathrm{F}\right)\right]}\end{array}$} & \multirow{2}{*}{$\begin{array}{c}\text { Condensing heat } \\
\text { transfer coefficient } \\
{\left[\mathrm{W} / \mathrm{m}^{2} \cdot \mathrm{K}\right.} \\
\left.\left(\mathrm{Btu} / \mathrm{h} \cdot \mathrm{ft}^{2} \cdot \bullet^{\circ} \mathrm{F}\right)\right]\end{array}$} \\
\hline & & $Q_{c}$ & $\mathbf{Q}_{w}$ & & & & \\
\hline $\mathrm{R}-11-001 \mathrm{M}$ to $004 \mathrm{M}$ & 1302 & (4442) & $1282(4376)$ & 1.5 & $311.5-313.7(101.0-105.0)$ & $14.0(25.1)$ & $950.4(167.6)$ \\
\hline$R-11-005 M$ to $008 M$ & 2057 & $(7021)$ & $2050(6998)$ & 0.3 & $312.9-316.1(103.5-109.4)$ & $22.2(39.9)$ & $946.1(166.9)$ \\
\hline$R-11-009 \mathrm{M}$ to $012 \mathrm{M}$ & 690 & (2354) & $717(2446)$ & 3.9 & $314.2-315.8(105.8-108.8)$ & $6.4(11.4)$ & $1107.2(195.3)$ \\
\hline$R-11-013$ M to $016 \mathrm{M}$ & 689 & (2351) & $722(2465)$ & 4.8 & $314.2-316.0(106.0-109.1)$ & $6.5(11.7)$ & $1081.6(190.8)$ \\
\hline$R-11-017$ y to $020 \mathrm{M}$ & 1036 & (3535) & $1045(3565)$ & 0.9 & $313.0-313.8(103.7-105.1)$ & $10.9(19.6)$ & $968.8(170.9)$ \\
\hline $\mathrm{R}-11-021 \mathrm{M}$ to $024 \mathrm{M}$ & 2429 & (8289) & $2371(8093)$ & 2.4 & $316.2-320.4(109.5-117.0)$ & $26.1(47.0)$ & $948.0(167.2)$ \\
\hline $\mathrm{R}-11-025 \mathrm{M}$ to $028 \mathrm{M}$ & 1568 & (5352) & $1562(5331)$ & 0.4 & $312.1-314.6(102.0-106.6)$ & $17.0(30.7)$ & $938.2(165.5)$ \\
\hline$R-11-029 M$ to $032 M$ & 1792 & $(6115)$ & $1783(6087)$ & 0.5 & $311.9-314.8(101.7-106.9)$ & $19.4(34.9)$ & $941.7(166.08)$ \\
\hline
\end{tabular}


Table B.7. Summary of experimental cond1tions and results from W1lson plots for $R-11$ condensing on vertical Tube $N$

\begin{tabular}{|c|c|c|c|c|c|c|}
\hline \multirow{2}{*}{ Series of runs } & \multicolumn{2}{|c|}{$\begin{array}{l}\text { Condenser heat load } \\
{[\mathrm{W}(\mathrm{Btu} / \mathrm{h})]}\end{array}$} & \multirow{2}{*}{$\begin{array}{c}\text { Difference } \\
(\%)\end{array}$} & \multirow{2}{*}{$\begin{array}{c}\text { Vapor temperature range } \\
{\left[K\left({ }^{\circ} \mathrm{F}\right)\right]}\end{array}$} & \multirow{2}{*}{$\begin{array}{r}\text { Condensing } \\
\text { temperature } \\
\text { difference } \\
{\left[K\left({ }^{\circ} F\right)\right]} \\
\end{array}$} & \multirow{2}{*}{$\begin{array}{c}\text { Condensing heat } \\
\text { transfer coeff lcient } \\
{\left[\mathrm{W} / \mathrm{m}^{2} \cdot \mathrm{K}\right.} \\
\left(\mathrm{Btu} / \mathrm{h} \cdot \mathrm{ft} \mathrm{t}^{\left.\left.2 \cdot{ }^{\circ} \mathrm{F}\right)\right]}\right.\end{array}$} \\
\hline & $Q_{c}$ & $Q_{w}$ & & & & \\
\hline$R-11-001 N$ to $004 N$ & $680(2322)$ & $713(2433)$ & 4.78 & $311.2-312.1(100.4-102.1)$ & $6.5(11.7)$ & $1065.2(187.9)$ \\
\hline$R-11-005 N$ to $008 N$ & $680(2321)$ & 735 (2507) & 8.04 & $311.3-312.3(100.7-102.4)$ & $6.6(11.9)$ & $1050.4(185.3)$ \\
\hline$R-11-009 \mathrm{~N}$ to $012 \mathrm{~N}$ & $1565(5340)$ & $1560(5323)$ & 0.3 & $311.1-313.4(100.3-104.5)$ & $17.1(30.7)$ & $932.9(164.5)$ \\
\hline$R-11-013 \mathrm{~N}$ to $016 \mathrm{~N}$ & $2428(8285)$ & $2377(8112)$ & 2.1 & $315.7-319.4(108.6-115.3)$ & $26.5(47.7)$ & $931.8(164.3)$ \\
\hline $\mathrm{R}-11-017 \mathrm{~N}$ to $020 \mathrm{~N}$ & $984(3358)$ & $1002(3420)$ & 1.9 & $310.8-312.1(99.8-102.1)$ & $10.2(18.4)$ & $978.7(172.6)$ \\
\hline $\mathrm{R}-11-021 \mathrm{~N}$ to $024 \mathrm{~N}$ & $2132(7276)$ & $2114(7214)$ & 0.8 & $312.4-315.6(102.7-108.4)$ & $23.6(42.5)$ & $918.9(162.1)$ \\
\hline $\mathrm{R}-11-025 \mathrm{~N}$ to $028 \mathrm{~N}$ & $1259(4297)$ & $1251(4268)$ & 0.7 & $311.0-312.8(100.2-103.3)$ & $13.3(24.0)$ & $961.7(169.6)$ \\
\hline$R-11-029 \mathrm{~N}$ to $032 \mathrm{~N}$ & $1837(6269)$ & $1832(6253)$ & 0.3 & $311.7-314.0(101.5-105.5)$ & $20.3(36.6)$ & $919.1(162.1)$ \\
\hline
\end{tabular}


Table B.8. Summary of experimental conditions and results from Wilson plots for R-11 condensing on vertical Tube 0 (no rod on water side)

\begin{tabular}{|c|c|c|c|c|c|c|}
\hline \multirow{2}{*}{ Series of runs } & \multicolumn{2}{|c|}{$\begin{array}{l}\text { Condenser heat load } \\
\qquad[\mathrm{W}(\mathrm{Btu} / \mathrm{h})]\end{array}$} & \multirow{2}{*}{$\begin{array}{l}\text { Difference } \\
(\%)\end{array}$} & \multirow{2}{*}{$\begin{array}{l}\text { Vapor temperature range } \\
{\left[K\left({ }^{\circ} \mathrm{F}\right)\right]}\end{array}$} & \multirow{2}{*}{$\begin{array}{l}\text { Condensing } \\
\text { temperature } \\
\text { difference } \\
{\left[R\left({ }^{\circ} \mathrm{F}\right)\right]}\end{array}$} & \multirow{2}{*}{$\begin{array}{c}\text { Condensing heat } \\
\text { transfer coeffictent } \\
{\left[\mathrm{W} / \mathrm{m}^{2} \cdot \mathrm{K}\right.} \\
\left(\mathrm{Btu} / \mathrm{h} \cdot \mathrm{ft}^{\left.\left.2 \cdot{ }^{\circ} \mathrm{F}\right)\right]}\right.\end{array}$} \\
\hline & $Q_{c}$ & $Q_{W}$ & & & & \\
\hline$R-11-0010$ to 0040 & $1721(5873)$ & $1728(5898)$ & -0.4 & $308.7-310.9(95.9-99.9)$ & $10.2(18.4)$ & $1627.8(287.1)$ \\
\hline$R-11-0050$ to 0080 & $2527(8626)$ & $2483(8474)$ & 1.8 & $309.1-313.2(96.7-104.1)$ & $15.7(28.2)$ & $1561.3(275.4)$ \\
\hline$R-11-0090$ to 0120 & $955(3260)$ & $945(3226)$ & 1.1 & $309.7-310.8(97.9-99.7)$ & $5.0(8.9)$ & $1863.5(328.7)$ \\
\hline$R-11-0130$ to 0160 & $2595(8858)$ & $2528(8629)$ & 2.6 & $311.8-315.8(101.6-108.7)$ & $16.1(28.9)$ & $1566.6(276.3)$ \\
\hline $\mathrm{R}-11-0170$ to 0200 & $794(2710)$ & $804(2744)$ & -1.3 & $310.5-311.3(99.3-100.6)$ & $4.0(7.2)$ & $1912.6(337.3)$ \\
\hline $\mathrm{R}-11-0210$ to 0240 & $1972(6729)$ & $1956(6676)$ & 0.8 & $309.1-311.8(96.7-101.6)$ & $12.1(21.7)$ & $1583.5(279.3)$ \\
\hline$R-11-0250$ to 0280 & $1178(4021)$ & 1170 (3993) & 0.7 & $310.1-311.8(98.4-101.6)$ & $6.4(11.5)$ & $1790.1(315.7)$ \\
\hline$R-11-0290$ to 0320 & $2176(7428)$ & $2141(7307)$ & 1.6 & $309.2-312.3(96.8-102.4)$ & $13.2(23.8)$ & $1594.2(281.2)$ \\
\hline$R-11-0330$ to 0360 & $1471(5022)$ & $1464(4996)$ & 0.5 & $310.0-312.1(98.4-102.1)$ & $8.3(15.0)$ & $1711.1(301.8)$ \\
\hline$R-11-0370$ to 0400 & $2373(8100)$ & $2308(7877)$ & 2.8 & $309.4-313.2(97.3-104.1)$ & $14.5(26.2)$ & $1580.9(278.8)$ \\
\hline$R-11-0410$ to 0440 & $783(2672)$ & $750(2560)$ & 4.17 & $311.3-312.2(100.6-102.3)$ & $3.9(7.1)$ & $1927.1(339.9)$ \\
\hline$R-11-0450$ to 0480 & $2880(9828)$ & $2726(9305)$ & 5.32 & $310.3-314.2(98.9-105.9)$ & $20.4(36.8)$ & $1365.8(240.9)$ \\
\hline
\end{tabular}


Table 8.9. Summary of experimental conditions and results from Wilson plots for $R-11$ condensing on vertical Tube $R$

\begin{tabular}{|c|c|c|c|c|c|c|}
\hline \multirow{2}{*}{ Series of runs } & \multicolumn{2}{|c|}{$\begin{array}{c}\text { Condenser heat load } \\
{[\mathrm{W}(\mathrm{Btu} / \mathrm{h})]}\end{array}$} & \multirow{2}{*}{$\begin{array}{c}\text { Difference } \\
(x)\end{array}$} & \multirow{2}{*}{$\begin{array}{c}\text { Vapor temperature range } \\
{\left[K\left({ }^{\circ} \mathrm{F}\right)\right]}\end{array}$} & \multirow{2}{*}{$\begin{array}{r}\text { Condensing } \\
\text { temperature } \\
\text { difference } \\
{\left[K\left({ }^{\circ} \mathrm{F}\right)\right]} \\
\end{array}$} & \multirow{2}{*}{$\begin{array}{c}\text { Condensing heat } \\
\text { transfer coefficient } \\
{\left[\mathrm{W} / \mathrm{m}^{2} \cdot \mathrm{K}\right.} \\
\left.\left(B t u / \mathrm{h} \cdot \mathrm{ft}^{2} \cdot{ }^{\circ} \mathrm{F}\right)\right]\end{array}$} \\
\hline & $\mathbf{Q}_{\mathbf{c}}$ & $\mathbf{Q}_{\mathbf{w}}$ & & & & \\
\hline$R-11-001$ R to $004 R$ & $880(3002)$ & $850(2901)$ & 3.4 & $312.1-313.6(102.0-104.8)$ & $2.4(4.4)$ & $3421.0(603.4)$ \\
\hline$R-11-005 R$ to $008 R$ & $3479(11873)$ & $3402(11612)$ & 2.2 & $309.0-317.0(96.6-111.0)$ & $15.0(27.0)$ & $2202.0(388.0)$ \\
\hline$R-11-009 R$ to $012 R$ & $1128(3850)$ & $1122(3828)$ & 0.6 & $311.6-314.0(101.2-105.5)$ & $3.4(6.0)$ & $3190.0(563.0)$ \\
\hline$R-11-013 \mathrm{R}$ to $016 \mathrm{R}$ & $3205(10938)$ & $3143(10729)$ & 1.9 & $309.5-316.3(97.4-109.7)$ & $13.7(24.7)$ & $2217.0(391.0)$ \\
\hline$R-11-017 R$ to $020 R$ & $1480(5051)$ & $1476(5037)$ & 0.3 & $311.0-313.5(100.1-104.7)$ & $4.9(8.8)$ & $2863.0(505.0)$ \\
\hline$R-11-021$ R to $024 R$ & $2810(9589)$ & $2779(9483)$ & 1.1 & $309.6-315.5(97.6-108.3)$ & $11.5(20.7)$ & $2317.0(409.0)$ \\
\hline$R-11-025 R$ to $029 R$ & $1771(6046)$ & $1766(6027)$ & 0.3 & $310.7-313.9(99.6-105.3)$ & $6.2(11.1)$ & $2718.4(479.4)$ \\
\hline$R-11-030 \mathrm{R}$ to $033 \mathrm{R}$ & $2480(8463)$ & 2449 (8359) & 1.2 & $309.9-315.5 \cdot(98.2-108.2)$ & $9.7(17.4)$ & $2432.1(429.0)$ \\
\hline$R-11-034$ R to $037 R$ & $2143(7314)$ & $2124(7249)$ & 0.9 & $310.0-314.0 \cdot(98.3-105.5)$ & $7.9(14.3)$ & $2557.4(451.1)$ \\
\hline
\end{tabular}


Table B.10. Summary of experimental condftions and results from Wilson plots for R-11 condensing on vertical Tube $S$

\begin{tabular}{|c|c|c|c|c|c|c|c|}
\hline \multirow{2}{*}{ Series of runs } & \multicolumn{3}{|c|}{$\begin{array}{c}\text { Condenser heat load } \\
{[\mathrm{H}(\mathrm{Btu} / \mathrm{h})]}\end{array}$} & \multirow{2}{*}{$\begin{array}{l}\text { Difference } \\
\text { (z) }\end{array}$} & \multirow{2}{*}{$\begin{array}{c}\text { Vapor temperature range } \\
{\left[\mathrm{K}\left({ }^{\circ} \mathrm{F}\right)\right]}\end{array}$} & \multirow{2}{*}{$\begin{array}{l}\text { Cóndensing } \\
\text { temperature } \\
\text { difference } \\
{\left[\mathrm{K}\left({ }^{\circ} \mathrm{F}\right)\right]}\end{array}$} & \multirow{2}{*}{$\begin{array}{c}\text { Condensing heat } \\
\text { transfer coefficient } \\
{\left[\mathrm{W} / \mathrm{m}^{2} \cdot \mathrm{K}\right.} \\
\left.\left(\mathrm{Btu} / \mathrm{h} \cdot \mathrm{ft}^{2} \cdot{ }^{\circ} \mathrm{F}\right)\right]\end{array}$} \\
\hline & $\because$ & $Q_{c}$ & $Q_{w}$ & & & & \\
\hline $\mathrm{R}-11-001 \mathrm{~S}$ to $004 \mathrm{~S}$ & 2119 & (7231) & $2105(7185)$ & 0.6 & $310.0-313.8(98.4-105.2)$ & $7.5(13.5)$ & $2856.7(503.8)$ \\
\hline $\mathrm{R}-1 \cdot 1-005 \mathrm{~S}$ to $008 \mathrm{~S}$ & 1003 & (3423) & 996 (3399) & 0.7 & $311.6-312.9(101.2-103.5)$ & $2.6(4.7)$ & $3906.7(689.0)$ \\
\hline $\mathrm{R}-11-009 \mathrm{~S}$ to $012 \mathrm{~S}$ & 3315 & $(11313)$ & $3375(11518)$ & -1.8 & $312.5-318.8(102.7-114.1)$ & $16.5(29.7)$ & $2036.7(359.0)$ \\
\hline $\mathrm{R}-11-013 \mathrm{~S}$ to $016 \mathrm{~S}$ & 1554 & $(5304)$ & $1560(5324)$ & -0.4 & $310.2-312.6(98.6-103.0)$ & $4.8(8.6)$ & $3296.0(581.0)$ \\
\hline $\mathrm{R}-11-017 \mathrm{~S}$ to $020 \mathrm{~S}$ & 3093 & (10556) & $3061(10448)$ & 1.0 & $310.2-315.9(98.7-109.0)$ & $14.0(25.3)$ & $2234.0(394.0)$ \\
\hline$R-11-021 \mathrm{~S}$ to $024 \mathrm{~S}$ & 1228 & (4193) & $1228(4190)$ & 0.1 & $310.8-312.6(99.8-103.0)$ & $3.5(6.2)$ & $3605.5(635.9)$ \\
\hline $\mathrm{R}-11-025 \mathrm{~S}$ to $028 \mathrm{~S}$ & 2754 & (9401) & $2708(9242)$ & -1.7 & $309.2-314.1(97.0-105.7)$ & $11.4(20.6)$ & $2442.8(430.8)$ \\
\hline$R-11-029 \mathrm{~S}$ to $031 \mathrm{~s}$ & 751 & (2563) & $759(2591)$ & -1.1 & $311.2-31.1 .4(100.1-100.8)$ & $1.8(3.2)$ & $4300.5(758.5)$ \\
\hline$R-11-032 \mathrm{~S}$ to $035 \mathrm{~S}$ & 1862 & $(6355)$ & $1875(6399)$ & -0.7 & $310.7-314.0(99.6-105.6)$ & $6.1(10.7)$ & $3101.8(547.1)$ \\
\hline
\end{tabular}


Table B.11. Summary of experimental conditions and results from Wilson plots for R-11 condensing on vertical Tube $T$

\begin{tabular}{|c|c|c|c|c|c|c|}
\hline \multirow{2}{*}{ Series of runs } & \multicolumn{2}{|c|}{$\begin{array}{l}\text { Condenser heat load } \\
{[\mathrm{W}(\mathrm{Btu} / \mathrm{h})]}\end{array}$} & \multirow{2}{*}{$\begin{array}{l}\text { Difference } \\
(\%)\end{array}$} & \multirow{2}{*}{$\begin{array}{c}\text { Vapor temperature range } \\
{\left[K\left({ }^{\circ} \mathrm{F}\right)\right]}\end{array}$} & \multirow{2}{*}{$\begin{array}{l}\text { Condensing } \\
\text { temperature } \\
\text { difference } \\
{\left[\mathrm{K}\left({ }^{\circ} \mathrm{F}\right)\right]}\end{array}$} & \multirow{2}{*}{$\begin{array}{c}\text { Condensing heat } \\
\text { transfer coefficient } \\
{\left[\mathrm{W} / \mathrm{m}^{2} \cdot \mathrm{K}\right.} \\
\left(\mathrm{Btu} / \mathrm{h} \cdot \mathrm{ft}^{\left.\left.2 \cdot{ }^{\circ} \mathrm{F}\right)\right]}\right.\end{array}$} \\
\hline & $Q_{c}$ & $Q_{w}$ & & & & \\
\hline $\mathrm{R}-11-001 \mathrm{~T}$ to $004 \mathrm{~T}$ & $2109(7199)$ & $2136(7289)$ & -1.3 & $311.1-316.9(100.4-110.7)$ & $3.7(6.7)$ & $3789.7(668.4)$ \\
\hline$R-11-005 T$ to $008 T$ & $3791(12940)$ & $3794(12948)$ & -0.1 & $310.9-322.4(99.9-120.7)$ & $9.6(17.3)$ & $2649.1(467.2)$ \\
\hline $\mathrm{R}-11-009 \mathrm{~T}$ to $012 \mathrm{~T}$ & $1419(4842)$ & $1429(4875)$ & -0.7 & $312.6-316.3(103.0-109.7)$ & $2.2(4.0)$ & $4307.1(759.6)$ \\
\hline $\mathrm{R}-11-013 \mathrm{~T}$ to $016 \mathrm{~T}$ & $2919(9962)$ & $2908(9926)$ & 0.4 & $310.1-318.4(98.4-113.4)$ & $6.1(11.0)$ & $3203.3(565.0)$ \\
\hline $\mathrm{R}-11-017 \mathrm{~T}$ to $020 \mathrm{~T}$ & $1800(6142)$ & $1812(6183)$ & -0.7 & $312.1-317.3(102.1-111.5)$ & $3.1(5.5)$ & $3947.6(696.2)$ \\
\hline $\mathrm{R}-11-021 \mathrm{~T}$ to $024 \mathrm{~T}$ & 3447 (11763) & $3426(11693)$ & 0.6 & $310.0-320.2(98.3-116.7)$ & $8.2(14.7)$ & $2827.8(498.7)$ \\
\hline $\mathrm{R}-11-025 \mathrm{~T}$ to $028 \mathrm{~T}$ & $2497(8522)$ & $2498(8524)$ & 0.0 & $310.6-318.1(99.5-112.9)$ & $4.7(8.5)$ & $3558.2(627.5)$ \\
\hline $\mathrm{R}-11-029 \mathrm{~T}$ to $032 \mathrm{~T}$ & $4047(13813)$ & $4036(13773)$ & 0.3 & $313.8-326.4(105.2-127.9)$ & $11.4(20.4)$ & $2389.5(421.4)$ \\
\hline $\mathrm{R}-11-033 \mathrm{~T}$ to $036 \mathrm{~T}$ & $1004(3425)$ & 998 (3407) & 0.5 & $312.9-315.2(103.5-107.6)$ & $1.4(2.6)$ & $4750.5(837.8)$ \\
\hline$R-11-037 \mathrm{~T}$ to $040 \mathrm{~T}$ & $1046(3572)$ & $1005(3431)$ & 3.9 & $312.9-315.8(103.5-108.7)$ & $1.4(2.6)$ & $4937.0(870.7)$ \\
\hline
\end{tabular}


Table B.12. Summary of experimental conditions and results from Wilson plots for R-11 condensing on vertical Tube $U$

\begin{tabular}{|c|c|c|c|c|c|c|}
\hline \multirow{2}{*}{ Series of runs } & \multicolumn{2}{|c|}{$\begin{array}{c}\text { Condenser heat load } \\
{[\mathrm{W}(\mathrm{Btu} / \mathrm{h})]}\end{array}$} & \multirow{2}{*}{$\begin{array}{c}\text { Difference } \\
(\%)\end{array}$} & \multirow{2}{*}{$\begin{array}{c}\text { Vapor temperature range } \\
{\left[\mathrm{K}\left({ }^{\circ} \mathrm{F}\right)\right]}\end{array}$} & \multirow{2}{*}{$\begin{array}{r}\text { Condensing } \\
\text { temperature } \\
\text { difference } \\
{\left[\mathrm{K}\left({ }^{\circ} \mathrm{F}\right)\right]}\end{array}$} & \multirow{2}{*}{$\begin{array}{c}\text { Condensing heat } \\
\text { transfer coefficient } \\
{\left[\mathrm{W} / \mathrm{m}^{2} \cdot \mathrm{K}\right.} \\
\left(\mathrm{Btu} / \mathrm{h} \cdot \mathrm{ft}^{\left.\left.2 \cdot{ }^{\circ} \mathrm{F}\right)\right]}\right. \\
\end{array}$} \\
\hline & $Q_{c}$ & $Q_{w}$ & & & & \\
\hline $\mathrm{R}-11-001 \mathrm{U}$ to $004 \mathrm{U}$ & $2093 \cdot(7144)$ & $2082(7107)$ & 0.5 & $310.7-315.3(99.5-107.9)$ & $7.1(12.8)$ & $2547.3(449.3)$ \\
\hline$R-11-005 \mathrm{U}$ to $008 \mathrm{U}$ & $856(2920)$ & $870(2968)$ & -1.6 & $311.1-313.2(100.4-104.0)$ & $1.6(2.9)$ & $4574.0(806.7)$ \\
\hline$R-11-009$ U to $012 \mathrm{U}$ & $3114(10628)$ & $3098(10573)$ & 0.5 & $313.7-321.3(105.0-118.8)$ & $13.2(23.8)$ & $2047.1(361.0)$ \\
\hline $\mathrm{R}-11-013 \mathrm{U}$ to $016 \mathrm{U}$ & $1089(3717)$ & $1095(3737)$ & -0.5 & $311.4-313.6(100.8-104.9)$ & $2.3(4.1)$ & $4160.3(733.7)$ \\
\hline $\mathrm{R}-11-017 \mathrm{U}$. to $020 \mathrm{U}$ & $2759(9417)$ & $2737(9341)$ & 0.8 & $310.6-317.3(99.4-111.4)$ & $11.0(19.8)$ & $2182.5(384.9)$ \\
\hline $\mathrm{R}-11-021 \mathrm{U}$ to $024 \mathrm{U}$ & $1418(4839)$ & $1434(4895)$ & -1.2 & $311.1-314.3(100.4-106.2)$ & $3.6(6.4)$ & $3439.9(606.7)$ \\
\hline$R-11-025 \mathrm{U}$ to $028 \mathrm{U}$ & $2407(8216)$ & $2368(8082)$ & 1.63 & $311.2-316.8(100.5-110.6)$ & $9.0(16.1)$ & $2330.8(411.4)$ \\
\hline $\mathrm{R}-11-029 \mathrm{U}$ to $032 \mathrm{U}$ & $1766(6026)$ & $1760(6006)$ & 0.3 & $311.1-314.6(100.2-106.5)$ & $5.3(9.6)$ & $2870.6(506.3)$ \\
\hline
\end{tabular}




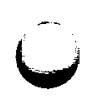

$\mathcal{U}$ 


\section{Appendix C}

EXPERIMENTAL DATA

Tables C.1 through C.13 document 124 runs that yielded 494 heat transfer data points. The tables summarize experimental data used in data reduction and for construction of Wilson plots. Table C.1 is taken from Ref. 3. The tables list overall heat transfer coefficients, in addition to saturation pressures and heat balance checks. Water velocities are presented with Reynolds numbers for the various water flow rates. The information was generated by a computer code used for data reduction, and the runs are grouped in series corresponding to Wilson plots. 
Toble C.I. Expertmental data for R-11 condensing on Tube A

\begin{tabular}{|c|c|c|c|c|c|c|c|c|c|c|c|c|c|c|c|c|c|}
\hline Run No. & Pry & $\underset{\text { (psis) }}{p}$ & ial & $\underset{(\mathbf{s p m})}{\mathbf{F}_{\mathrm{c}}}$ & $\underset{c}{T_{c}}$ & $\left(b_{m} / h\right)$ & $\underset{(\mathrm{EPm})}{F_{w}}$ & (ii/s) & Re & $T_{\text {win }}$ & $T_{\text {wout }}$ & $T_{w}$ & $\begin{array}{l}\Delta \mathbf{T} \\
(\mathbf{P})\end{array}$ & $\underset{(B u w / h)}{Q_{c}}$ & $\begin{array}{c}Q_{w} \\
(B t u / h)\end{array}$ & $\underset{(\%)}{\Delta}$ & 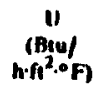 \\
\hline $\begin{array}{l}R-11-037 A \\
R-11-038 \AA \\
8-11-0391 \\
R=11-0401\end{array}$ & $\begin{array}{r}108.87 \\
110.40 \\
111.42 \\
113.86\end{array}$ & $\begin{array}{l}28.0 \\
28.5 \\
29.9\end{array}$ & $\begin{array}{l}27.4 \\
28.1 \\
28.6 \\
29.8\end{array}$ & $\begin{array}{l}0.0807 \\
0.0807 \\
0.0815 \\
0.0803\end{array}$ & $\begin{array}{r}97.63 \\
99.78 \\
101.54 \\
104.02\end{array}$ & $\begin{array}{l}58.56 \\
58.44 \\
58.90 \\
57.88\end{array}$ & $\begin{array}{r}21.6 \\
7.6 \\
5.2 \\
3.0\end{array}$ & $\begin{array}{r}17.6 \\
6.1 \\
4.2 \\
2.4\end{array}$ & $\begin{array}{r}59687 . \\
20743 . \\
14195 . \\
8254 .\end{array}$ & $\begin{array}{l}81.80 \\
81.18 \\
60.93 \\
81.01\end{array}$ & $\begin{array}{l}82.27 \\
82.38 \\
82.65 \\
83.86\end{array}$ & $\begin{array}{l}0.41 \\
1.18 \\
1.70 \\
2.81\end{array}$ & $\begin{array}{l}26.84 \\
28.63 \\
29.63 \\
31.42\end{array}$ & $\begin{array}{l}4357 . \\
4340 . \\
4369 . \\
4280\end{array}$ & $\begin{array}{l}4470 . \\
4478 . \\
4400 . \\
4206 .\end{array}$ & $\begin{array}{r}-2.6 \\
-3.2 \\
-0.7 \\
1.7\end{array}$ & $\begin{array}{l}155 . \\
145 . \\
141 . \\
130 .\end{array}$ \\
\hline $\begin{array}{l}B-11-0411 \\
R-11-0.2 A \\
R-11-0431 \\
B-11-0441\end{array}$ & $\begin{array}{r}98.40 \\
99.07 \\
99.47 \\
100.88\end{array}$ & $\begin{array}{l}23.0 \\
23.4 \\
23.7 \\
24.0\end{array}$ & $\begin{array}{l}22.8 \\
23.1 \\
23.2 \\
23.8\end{array}$ & $\begin{array}{l}0.0483 \\
0.0483 \\
0.0479 \\
0.0475\end{array}$ & $\begin{array}{l}88.24 \\
88.73 \\
89.07 \\
90.10\end{array}$ & $\begin{array}{l}35.36 \\
35.34 \\
35.01 \\
34.66\end{array}$ & $\begin{array}{r}21.8 \\
7.6 \\
5.2 \\
3.0\end{array}$ & $\begin{array}{r}17.6 \\
6.1 \\
4.2 \\
2.4\end{array}$ & $\begin{array}{r}60307 . \\
20971 . \\
14338 \\
8292\end{array}$ & $\begin{array}{l}82.72 \\
82.29 \\
82.09 \\
81.89\end{array}$ & $\begin{array}{l}83.04 \\
83.05 \\
83.13 \\
83.73\end{array}$ & $\begin{array}{l}0.26 \\
0.72 \\
1.04 \\
1.76\end{array}$ & $\begin{array}{l}15.53 \\
16.40 \\
16.87 \\
18.07\end{array}$ & $\begin{array}{l}2665 . \\
2662 . \\
2636 \\
2605 .\end{array}$ & $\begin{array}{l}2806 . \\
2749 . \\
2698 . \\
2634 .\end{array}$ & $\begin{array}{l}-5.3 \\
-3.3 \\
-2.3 \\
-1.1\end{array}$ & $\begin{array}{l}164 . \\
155 . \\
149 . \\
138 .\end{array}$ \\
\hline $\begin{array}{l}\mathrm{B}-11-0451 \\
8-11-046 \mathrm{~A} \\
\mathrm{~B}-11-0471 \\
\mathrm{~B}-11-048 \mathrm{~A}\end{array}$ & $\begin{array}{l}101.33 \\
102.12 \\
102.79 \\
104.57\end{array}$ & $\begin{array}{l}24.0 \\
24.4 \\
24.7 \\
25.4\end{array}$ & $\begin{array}{l}24.0 \\
24.3 \\
24.6 \\
25.4\end{array}$ & $\begin{array}{l}0.0575 \\
0.0583 \\
0.0581 \\
0.0574\end{array}$ & $\begin{array}{l}99.67 \\
91.34 \\
92.14 \\
93.92\end{array}$ & $\begin{array}{l}41.99 \\
42.52 \\
42.33 \\
41.79\end{array}$ & $\begin{array}{r}21.8 \\
7.6 \\
5.2 \\
3.0\end{array}$ & $\begin{array}{r}17.6 \\
6.1 \\
4.2 \\
2.4\end{array}$ & $\begin{array}{r}59997 . \\
20762 . \\
14191 . \\
8231 .\end{array}$ & $\begin{array}{l}82.27 \\
81.41 \\
81.14 \\
81.14\end{array}$ & $\begin{array}{l}82.64 \\
82.30 \\
82.40\end{array}$ & $\begin{array}{l}0.30 \\
0.86 \\
1.25 \\
2.08\end{array}$ & $\begin{array}{l}18.88 \\
20.26 \\
21.02 \\
22.36\end{array}$ & $\begin{array}{l}3154 . \\
3191 . \\
3174 . \\
3127 .\end{array}$ & $\begin{array}{l}3317 . \\
3257 . \\
3232 . \\
3118 .\end{array}$ & $\begin{array}{r}-5.2 \\
-2.1 \\
-1.8 \\
0.3\end{array}$ & $\begin{array}{l}160 . \\
150 . \\
144 . \\
134 .\end{array}$ \\
\hline $\begin{array}{l}8-11-0491 \\
8-11-0502 \\
8-11-0512 \\
8-11-0522\end{array}$ & $\begin{array}{l}115.28 \\
117.69 \\
119.17 \\
122.11\end{array}$ & $\begin{array}{l}30.0 \\
31.2 \\
32.2 \\
33.7\end{array}$ & $\begin{array}{l}30.5 \\
31.7 \\
32.5 \\
34.1\end{array}$ & $\begin{array}{l}0.1054 \\
0.1064 \\
0.1064 \\
0.1062\end{array}$ & $\begin{array}{l}105.88 \\
109.06 \\
110.79 \\
113.57\end{array}$ & $\begin{array}{l}75.86 \\
76.33 \\
76.20 \\
75.84\end{array}$ & $\begin{array}{r}21.8 \\
7.6 \\
5.2 \\
3.0\end{array}$ & $\begin{array}{r}17.6 \\
6.1 \\
4.2 \\
2.4\end{array}$ & $\begin{array}{r}58363 . \\
20396 \\
13996 \\
8104\end{array}$ & $\begin{array}{l}79.92 \\
79.63 \\
79.54 \\
79.64\end{array}$ & $\begin{array}{l}80.51 \\
81.18 \\
81.76\end{array}$ & $\begin{array}{l}0.53 \\
1.52 \\
2.17 \\
3.55\end{array}$ & $\begin{array}{l}35.07 \\
37.28 \\
38.52 \\
41.17\end{array}$ & $\begin{array}{l}5599 . \\
5616 . \\
5596 . \\
5548 .\end{array}$ & & $\begin{array}{r}-2.2 \\
-3.0 \\
-0.7 \\
4.3\end{array}$ & $\begin{array}{l}153 . \\
144 . \\
139 . \\
129 .\end{array}$ \\
\hline $\begin{array}{l}8-11-0531 \\
R-11-054 A \\
z-11-055 A \\
-11-056 A\end{array}$ & $\begin{array}{l}120.86 \\
123.40 \\
125.42 \\
129.34\end{array}$ & $\begin{array}{l}32.9 \\
34.2 \\
35.4 \\
37.7\end{array}$ & $\begin{array}{l}33.4 \\
34.8 \\
36.0 \\
38.3\end{array}$ & $\begin{array}{l}0.1228 \\
0.1223 \\
0.1231 \\
0.1240\end{array}$ & $\begin{array}{l}110.05 \\
113.37 \\
116.26 \\
120.59\end{array}$ & $\begin{array}{l}87.98 \\
87.34 \\
87.65 \\
87.92\end{array}$ & $\begin{array}{r}21.8 \\
7.6 \\
5.2 \\
3.0\end{array}$ & $\begin{array}{r}17.6 \\
6.1 \\
4.2 \\
2.4\end{array}$ & $\begin{array}{r}58313 . \\
20419 . \\
14075 . \\
8248 .\end{array}$ & $\begin{array}{l}79.62 \\
79.63 \\
79.83 \\
80.30\end{array}$ & $\begin{array}{l}80.47 \\
81.38 \\
82.37 \\
84.45\end{array}$ & $\begin{array}{l}0.61 \\
1.74 \\
2.48 \\
4.11\end{array}$ & $\begin{array}{l}40.71 \\
42.90 \\
44.31 \\
46.96\end{array}$ & & & $\begin{array}{r}-2.6 \\
-3.7 \\
-1.0 \\
3.3\end{array}$ & $\begin{array}{l}151 . \\
142 . \\
138 . \\
130 .\end{array}$ \\
\hline 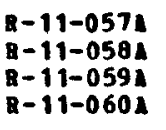 & $\begin{array}{l}126.17 \\
128.84 \\
130.90 \\
135.99\end{array}$ & $\begin{array}{l}35.7 \\
37.4 \\
38.7 \\
41.9\end{array}$ & $\begin{array}{l}36.4 \\
38.0 \\
39.2 \\
42.4\end{array}$ & $\begin{array}{l}0.1482 \\
0.1474 \\
0.1478 \\
0.1488\end{array}$ & $\begin{array}{l}119.35 \\
121.87 \\
124.07 \\
128.97\end{array}$ & $\begin{array}{l}105.24 \\
104.39 \\
104.49 \\
104.62\end{array}$ & $\begin{array}{r}21.5 \\
7.6 \\
5.2 \\
3.0\end{array}$ & $\begin{array}{r}17.3 \\
6.1 \\
4.2 \\
2.4\end{array}$ & $\begin{array}{c}56182^{\circ} \\
19992^{\circ} \\
13799^{\circ} \\
8127^{\circ}\end{array}$ & $\begin{array}{l}77.90 \\
77.78 \\
78.04 \\
78.71\end{array}$ & $\begin{array}{l}7 \\
7 \\
8\end{array}$ & $\begin{array}{l}.71 \\
.00 \\
.90 \\
.85\end{array}$ & $\begin{array}{l}47.88 \\
50.03 \\
51.40 \\
54.82\end{array}$ & & & $\begin{array}{r}-0.0 \\
-0.4 \\
0.5 \\
3.4\end{array}$ & $\begin{array}{l}153 . \\
144 . \\
140 . \\
131 .\end{array}$ \\
\hline $\begin{array}{l}R-11-061 A \\
R-11-062 A \\
R-11-063 A \\
B-11-064 A\end{array}$ & $\begin{array}{l}104.57 \\
105.81 \\
106.53 \\
108.74\end{array}$ & $\begin{array}{l}25.0 \\
25.7 \\
26.2 \\
27.2\end{array}$ & $\begin{array}{l}25.4 \\
26.0 \\
26.3 \\
27.3\end{array}$ & $\begin{array}{l}0.0696 \\
0.0700 \\
0.0702 \\
0.0700\end{array}$ & $\begin{array}{l}92.99 \\
94.67 \\
95.63 \\
98.04\end{array}$ & $\begin{array}{l}50.88 \\
51.00 \\
50.72\end{array}$ & $\begin{array}{l}7.6 \\
5.2 \\
3.0\end{array}$ & $\begin{array}{r}17.6 \\
6.1 \\
4.2 \\
2.4\end{array}$ & $\begin{array}{r}205 \\
140 \\
80\end{array}$ & $\begin{array}{l}81.05 \\
80.44 \\
80.03 \\
79.57\end{array}$ & $\begin{array}{l}81 \\
81 \\
82\end{array}$ & $\begin{array}{l}0.36 \\
1.03 \\
1.51 \\
2.58\end{array}$ & $\begin{array}{l}0 \\
3 \\
5 \\
7\end{array}$ & & & $\begin{array}{l}-3.3 \\
-3.2 \\
-3.1 \\
-2.2\end{array}$ & \\
\hline $\begin{array}{l}R-11-065 A \\
R-11-066 A \\
R-11-0672 \\
R-11-068 \lambda\end{array}$ & $\begin{array}{l}120.42 \\
123.21 \\
125.37 \\
130.13\end{array}$ & $\begin{array}{l}32.7 \\
34.2 \\
35.4 \\
38.2\end{array}$ & $\begin{array}{l}33.2 \\
34.7 \\
35.9 \\
38.7\end{array}$ & $\begin{array}{l}0.1349 \\
0.1355 \\
0.1362 \\
0.1368\end{array}$ & $\begin{array}{l}111.38 \\
114.67 \\
117.41 \\
122.41\end{array}$ & $\begin{array}{l}96.55 \\
96.64 \\
96.94 \\
96.84\end{array}$ & $\begin{array}{r}21.8 \\
7.6 \\
5.2 \\
3.0\end{array}$ & $\begin{array}{r}17.6 \\
6.1 \\
4.2 \\
2.4\end{array}$ & $\begin{array}{r}54906 . \\
19226 \\
13277 \\
7824 .\end{array}$ & $\begin{array}{l}75.03 \\
74.79 \\
75.08 \\
75.87\end{array}$ & $\begin{array}{l}75.77 \\
76.69 \\
77.84 \\
80.39\end{array}$ & $\begin{array}{l}0.67 \\
1.87 \\
2.72 \\
4.48\end{array}$ & $\begin{array}{l}45.02 \\
47.47 \\
48.91\end{array}$ & $\begin{array}{l}7078 . \\
7059 . \\
7060 . \\
7009 .\end{array}$ & & $\begin{array}{r}-3.3 \\
-0.4 \\
0.0 \\
4.4\end{array}$ & $\begin{array}{l}150 \\
142 \\
138 \\
129\end{array}$ \\
\hline $\begin{array}{l}\mathrm{B}-11-069 \mathrm{~A} \\
\mathrm{~B}-11-070 \mathrm{~A} \\
\mathrm{~B}-11-071 \mathrm{~A} \\
\mathrm{~B}-11-072 \mathrm{~A}\end{array}$ & $\begin{array}{l}109.94 \\
112.42 \\
114.13 \\
117.81\end{array}$ & $\begin{array}{l}27.5 \\
28.7 \\
29.7 \\
31.5\end{array}$ & $\begin{array}{l}27.9 \\
29.1 \\
29.9 \\
31.8\end{array}$ & $\begin{array}{l}0.0945 \\
0.0958 \\
0.0962 \\
0.0960\end{array}$ & $\begin{array}{r}98.40 \\
102.26 \\
104.63 \\
108.39\end{array}$ & $\begin{array}{l}68.50 \\
69.19 \\
69.31 \\
68.88\end{array}$ & $\begin{array}{r}21.8 \\
7.6 \\
5.2 \\
3.0\end{array}$ & $\begin{array}{r}17.6 \\
6.1 \\
4.2 \\
2.4\end{array}$ & $\begin{array}{c}56716 . \\
19825 . \\
13630 . \\
7995 .\end{array}$ & $\begin{array}{l}77.66 \\
77.42 \\
77.50 \\
78.11\end{array}$ & & $\begin{array}{l}0.48 \\
1.39 \\
2.00 \\
3.48\end{array}$ & $\begin{array}{l}32.01 \\
34.28 \\
35.61 \\
37.97\end{array}$ & $\begin{array}{l}50 \\
51 \\
51 \\
50\end{array}$ & & $\begin{array}{l}-2.3 \\
-3.0 \\
-1.5 \\
-2.9\end{array}$ & $\begin{array}{l}15 \\
14 \\
13 \\
12\end{array}$ \\
\hline $\begin{array}{l}8-11-0734 \\
8-11-074 A \\
8-11-0754 \\
8-11-076 A\end{array}$ & $\begin{array}{l}122.18 \\
124.19 \\
126.26 \\
132.93\end{array}$ & $\begin{array}{l}33.7 \\
34.9 \\
36.0\end{array}$ & $\begin{array}{l}34.1 \\
35.3 \\
36.4 \\
40.5\end{array}$ & $\begin{array}{l}0.1570 \\
0.1577 \\
0.1582 \\
0.1616\end{array}$ & $\begin{array}{l}113.72 \\
116.42 \\
118.70 \\
126.03\end{array}$ & $\begin{array}{l}112 . \\
112 . \\
112 . \\
113 .\end{array}$ & $\begin{array}{r}21.8 \\
7.6 \\
5.2 \\
3.0\end{array}$ & $\begin{array}{r}17.6 \\
6.1 \\
4.2 \\
2.4\end{array}$ & $\begin{array}{c}51308 . \\
17643 . \\
12136 . \\
7148 .\end{array}$ & $\begin{array}{l}69.72 \\
67.99 \\
67.92 \\
68.27\end{array}$ & $\begin{array}{l}70 . \\
70 . \\
71 . \\
73 .\end{array}$ & $\begin{array}{l}0.77 \\
2.20 \\
3.14 \\
5.48\end{array}$ & 55. & $\begin{array}{l}8199 . \\
8199 . \\
8195 . \\
8176 .\end{array}$ & $\begin{array}{l}8388 . \\
8347 . \\
8149 . \\
8222 .\end{array}$ & $\begin{array}{r}-2.3 \\
-1.9 \\
0.3 \\
-0.1\end{array}$ & $\begin{array}{l}15 \\
14 \\
13 \\
12\end{array}$ \\
\hline $\begin{array}{l}\mathrm{B}-11-077 \mathrm{~A} \\
\mathrm{~A}-11-078 \mathrm{~A} \\
\mathrm{R}-11-079 \mathrm{~A} \\
\mathrm{~B}-11-080 \mathrm{~A}\end{array}$ & $\begin{array}{l}94.54 \\
94.90 \\
95.27 \\
96.43\end{array}$ & $\begin{array}{l}21.0 \\
21.4 \\
21.4 \\
21.9\end{array}$ & $\begin{array}{l}21.3 \\
21.4 \\
21.6 \\
22.0\end{array}$ & $\begin{array}{l}0.0359 \\
0.0359 \\
0.0357 \\
0.0357\end{array}$ & $\begin{array}{l}83.28 \\
83.68 \\
83.89 \\
84.62\end{array}$ & $\begin{array}{l}26.38 \\
26.37 \\
26.21 \\
26.19\end{array}$ & $\begin{array}{r}21.8 \\
7.6 \\
5.2 \\
3.0\end{array}$ & $\begin{array}{r}17.6 \\
6.1 \\
4.2\end{array}$ & $\begin{array}{r}60257 . \\
20925 . \\
14338 . \\
8311 .\end{array}$ & $\begin{array}{l}82.68 \\
82.20 \\
82.20 \\
82.34\end{array}$ & $\begin{array}{l}82.94 \\
82.78 \\
83.02 \\
83.65\end{array}$ & $\begin{array}{l}0.20 \\
0.56 \\
0.79 \\
1.28\end{array}$ & $\begin{array}{l}11.73 \\
12.41 \\
12.67 \\
13.44\end{array}$ & $\begin{array}{l}1998 . \\
1997 . \\
1983 . \\
1979 .\end{array}$ & $\begin{array}{l}2175 . \\
2131 . \\
2039 . \\
1911 .\end{array}$ & $\begin{array}{r}-8.9 \\
-6.7 \\
-2.8 \\
3.4\end{array}$ & $\begin{array}{l}150 . \\
141 .\end{array}$ \\
\hline
\end{tabular}


Tabte C.2. Experimentel datu for R-11 condensing on Tube A-1

\begin{tabular}{|c|c|c|c|c|c|c|c|c|c|c|c|c|c|c|c|c|c|}
\hline Run No. & $\begin{array}{l}T_{\mathbf{v}} \\
P^{\prime}\end{array}$ & (psia) & $P_{\text {sal }}$ & $\underset{(\mathrm{gpm})}{\mathbf{F}_{\mathbf{c}}}$ & $\begin{array}{c}T_{c} \\
\left({ }^{\circ} \mathbf{F}\right)\end{array}$ & $b_{m}^{m} g_{h)}$ & $\underset{(\mathrm{gpm})}{F_{\mathrm{w}}}$ & $(\tilde{v} / \mathrm{s})$ & Re & $T_{m, i n}$ & W.out & $\begin{array}{r}T_{w} \\
F\end{array}$ & $\underset{C^{\circ} \mathbf{F}}{\Delta T}$ & $\underset{(B t u / h)}{\mathbf{Q}_{c}}$ & $\underset{(B u w / h)}{Q_{w}}$ & $\stackrel{\Delta}{(\mathscr{W})}$ & $\underset{\substack{\left(A_{1} u \mid \\
b \cdot f^{2} \cdot e_{f}\right)}}{U}$ \\
\hline $\begin{array}{l}8-11-00111 \\
8-11-00211 \\
R-11-00311 \\
8-11-00411\end{array}$ & $\begin{array}{r}99.23 \\
100.40 \\
101.72 \\
103.72\end{array}$ & $\begin{array}{l}2.7 \\
3.3 \\
3.9 \\
4.7\end{array}$ & $\begin{array}{l}23.1 \\
23.6 \\
24.2 \\
25.0\end{array}$ & $\begin{array}{l}0.0598 \\
0.0588 \\
0.0588 \\
0.0577\end{array}$ & $\begin{array}{l}95.63 \\
96.42 \\
97.42 \\
98.69\end{array}$ & $\begin{array}{l}43.47 \\
42.66 \\
42.62 \\
41.79\end{array}$ & $\begin{array}{r}22.2 \\
7.6 \\
5.2 \\
3.0\end{array}$ & $\begin{array}{r}17.9 \\
6.1 \\
4.2 \\
2.4\end{array}$ & $\begin{array}{r}61406 \\
21054 \\
14542 \\
8452\end{array}$ & $\begin{array}{l}82.71 \\
82.56 \\
83.16 \\
83.37\end{array}$ & $\begin{array}{l}83.03 \\
83.43 \\
84.38 \\
85.40\end{array}$ & $\begin{array}{l}0.29 \\
0.85 \\
1.21 \\
2.03\end{array}$ & $\begin{array}{l}16.36 \\
17.40 \\
17.95 \\
19.34\end{array}$ & $\begin{array}{l}3274 . \\
3208 . \\
3200 . \\
3130 .\end{array}$ & $\begin{array}{l}3212 . \\
3234 . \\
3134 . \\
3040 .\end{array}$ & $\begin{array}{r}1.9 \\
-0.8 \\
2.1 \\
2.9\end{array}$ & $\begin{array}{l}191 . \\
176 . \\
170 . \\
155 .\end{array}$ \\
\hline $\begin{array}{l}R-11-005 A 1 \\
R-11-006 A 1 \\
R-11-007 A 1 \\
R-11-008 A 1\end{array}$ & $\begin{array}{l}104.90 \\
108.33 \\
110.66 \\
115.32\end{array}$ & $\begin{array}{l}25.4 \\
26.9 \\
27.9 \\
30.4\end{array}$ & $\begin{array}{l}25.6 \\
27.1 \\
28.2 \\
30.5\end{array}$ & $\begin{array}{l}0.1268 \\
0.1256 \\
0.1256 \\
0.1255\end{array}$ & $\begin{array}{l}102.33 \\
104.92 \\
107.10 \\
110.95\end{array}$ & $\begin{array}{l}91.58 \\
90.45 \\
90.26 \\
89.86\end{array}$ & $\begin{array}{r}22.0 \\
7.6 \\
4.9 \\
3.0\end{array}$ & $\begin{array}{r}17.7 \\
6.1 \\
3.9 \\
2.4\end{array}$ & $\begin{array}{l}48863 \\
17137 \\
11102 \\
6862\end{array}$ & $\begin{array}{l}65.58 \\
66.11 \\
66.04 \\
65.88\end{array}$ & $\begin{array}{l}6.23 \\
7.88 \\
8.64 \\
0.19\end{array}$ & $\begin{array}{l}2.60 \\
4.31\end{array}$ & $\begin{array}{l}39.00 \\
41.33 \\
43.32 \\
47.28\end{array}$ & $\begin{array}{l}6849 . \\
6735 . \\
6701 . \\
6632 .\end{array}$ & $\begin{array}{l}7069 . \\
6680 . \\
6366 . \\
6457 .\end{array}$ & $\begin{array}{r}-3.2 \\
0.8 \\
5.0 \\
2.6\end{array}$ & $\begin{array}{l}168 . \\
156 . \\
148 . \\
134 .\end{array}$ \\
\hline $\begin{array}{l}R-11-009 \mathrm{~A} 1 \\
\mathrm{R}-11-010 \mathrm{~A} 1 \\
\mathrm{R}-11-011 \mathrm{~A} 1 \\
\mathrm{~B}-11-012 \mathrm{~A} 1\end{array}$ & $\begin{array}{l}108.31 \\
110.35 \\
112.60 \\
116.50\end{array}$ & $\begin{array}{l}26.9 \\
27.9 \\
29.0 \\
30.9\end{array}$ & $\begin{array}{l}27.1 \\
28.1 \\
29.1 \\
31.1\end{array}$ & $\begin{array}{l}0.0877 \\
0.0875 \\
0.0889 \\
0.0900\end{array}$ & $\begin{array}{l}104.77 \\
106.51 \\
108.23 \\
111.78\end{array}$ & $\begin{array}{l}63.15 \\
62.89 \\
63.80 \\
64.39\end{array}$ & $\begin{array}{r}22.2 \\
7.4 \\
5.2 \\
3.0\end{array}$ & $\begin{array}{r}17.9 \\
6.0 \\
4.2 \\
2.4\end{array}$ & $\begin{array}{l}61347 . \\
20534 \\
14576 \\
6495\end{array}$ & $\begin{array}{l}82.56 \\
82.49 \\
83.07 \\
83.27\end{array}$ & $\begin{array}{l}33.02 \\
33.77 \\
84.86 \\
36.35\end{array}$ & $\begin{array}{l}0.41 \\
1.29 \\
1.80 \\
3.06\end{array}$ & $\begin{array}{l}25.52 \\
27.22 \\
28.64 \\
31.69\end{array}$ & & & $\begin{array}{r}2.5 \\
-2.0 \\
0.9 \\
3.5\end{array}$ & $\begin{array}{l}176 . \\
164 . \\
158 . \\
143 .\end{array}$ \\
\hline $\begin{array}{l}R-11-013 A 1 \\
R-11-014 A 1 \\
R-11-015 A 1 \\
R-11-016 A 1\end{array}$ & $\begin{array}{l}107.58 \\
107.87 \\
108.53 \\
109.52\end{array}$ & 26.9 & $\begin{array}{l}26.8 \\
26.9 \\
27.2 \\
27.7\end{array}$ & $\begin{array}{l}0.0443 \\
0.0443 \\
0.0447 \\
0.0447\end{array}$ & $\begin{array}{l}102.18 \\
102.63 \\
103.11 \\
103.78\end{array}$ & $\begin{array}{l}31.97 \\
31.95 \\
32.25\end{array}$ & $\begin{array}{r}22.2 \\
7.6 \\
5.0 \\
3.0\end{array}$ & $\begin{array}{r}17.9 \\
6.1 \\
4.0 \\
2.4\end{array}$ & $\begin{array}{l}40 . \\
34 . \\
36 . \\
04 .\end{array}$ & $\begin{array}{l}96.44 \\
95.63 \\
95.23 \\
94.77\end{array}$ & $\begin{array}{l}67 \\
.26 \\
22 \\
35\end{array}$ & 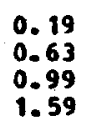 & $\begin{array}{l}11.02 \\
11.92 \\
12.80 \\
13.96\end{array}$ & & $\begin{array}{l}2120: \\
2381 . \\
2466 . \\
2370 .\end{array}$ & $\begin{array}{r}11.0 \\
-0.0 \\
-2.7 \\
1.1\end{array}$ & $\begin{array}{l}206 . \\
191 . \\
179 . \\
164 .\end{array}$ \\
\hline $\begin{array}{l}8-11-017 \mathrm{~A} \\
8-11-018 \mathrm{~A} 1 \\
8-11-01911 \\
8-11-020 A 1\end{array}$ & $\begin{array}{l}106.91 \\
109.95 \\
112.34 \\
116.79\end{array}$ & $\begin{array}{l}27.5 \\
28.5 \\
31.2\end{array}$ & $\begin{array}{l}26.5 \\
27.9 \\
29.0 \\
31.3\end{array}$ & $\begin{array}{l}0.0990 \\
0.1008 \\
0.1023 \\
0.1032\end{array}$ & $\begin{array}{l}103.92 \\
106.21 \\
108.50 \\
112.45\end{array}$ & $\begin{array}{l}71.39 \\
72.52 \\
73.43 \\
73.82\end{array}$ & $\begin{array}{r}22.2 \\
7.6 \\
5.2 \\
3.0\end{array}$ & $\begin{array}{r}17.9 \\
6.9 \\
4.2 \\
2.4\end{array}$ & $\begin{array}{c}57260 \\
19736 \\
13578 \\
7919\end{array}$ & $\begin{array}{l}77.00 \\
77.08 \\
77.17 \\
77.29\end{array}$ & $\begin{array}{l}1 \\
9 \\
8 \\
8\end{array}$ & $\begin{array}{l}47 \\
40 \\
09 \\
57\end{array}$ & $\begin{array}{l}29.66 \\
32.16 \\
34.11 \\
37.71\end{array}$ & $\begin{array}{l}5326 . \\
5389 . \\
5440 . \\
5437 .\end{array}$ & $\begin{array}{l}5250 . \\
5301 . \\
5419 . \\
5337 .\end{array}$ & $\begin{array}{l}1.4 \\
1.6 \\
0.4 \\
1.8\end{array}$ & $\begin{array}{l}172 . \\
160 \\
152 . \\
138 .\end{array}$ \\
\hline $\begin{array}{l}8-11-021 \mathrm{~A} 1 \\
\mathrm{~B}-11-022 \mathrm{~A} 1 \\
\mathrm{~B}-11-023 \mathrm{~A} 1 \\
\mathrm{R}-11-024 \mathrm{~A}\end{array}$ & $\begin{array}{l}106.40 \\
107.60 \\
108.69 \\
111.15\end{array}$ & $\begin{array}{l}25.9 \\
26.5 \\
26.9 \\
28.2\end{array}$ & $\begin{array}{l}26.2 \\
26.9 \\
27.9 \\
28.4\end{array}$ & $\begin{array}{l}0.0761 \\
0.0751 \\
0.0753 \\
0.0751\end{array}$ & $\begin{array}{l}103.04 \\
104.25 \\
105.38 \\
106.89\end{array}$ & $\begin{array}{l}54.94 \\
54.11 \\
54.21 \\
53.97\end{array}$ & $\begin{array}{r}22.2 \\
7.6 \\
5.2 \\
3.0\end{array}$ & $\begin{array}{r}17.9 \\
6.9 \\
4.2 \\
2.4\end{array}$ & $\begin{array}{l}62909 \\
21554 \\
14756 \\
8541\end{array}$ & $\begin{array}{l}84.66 \\
84.40 \\
84.20 \\
83.97\end{array}$ & $\begin{array}{l}85.07 \\
85.47 \\
85.76 \\
86.55\end{array}$ & $\begin{array}{l}0.36 \\
1.09 \\
1.57 \\
2.57\end{array}$ & $\begin{array}{l}21.53 \\
22.86 \\
23.91 \\
25.89\end{array}$ & $\begin{array}{l}4101 . \\
4032 . \\
4034 . \\
4005 .\end{array}$ & $\begin{array}{l}4043 . \\
4129 . \\
4078 . \\
3842 .\end{array}$ & $\begin{array}{r}1.4 \\
-2.4 \\
-1.1 \\
1.1\end{array}$ & $\begin{array}{l}182 . \\
168 . \\
161 . \\
148 .\end{array}$ \\
\hline $\begin{array}{l}\mathrm{A}-11-025 \mathrm{~A} \\
\mathrm{~B}-11-026 \mathrm{~A} 1 \\
\mathrm{~B}-11-027 \mathrm{~A} 1 \\
\mathrm{~g}-11-028 \mathrm{~A}\end{array}$ & $\begin{array}{l}104.97 \\
108.16 \\
110.33 \\
115.57\end{array}$ & $\begin{array}{l}25.5 \\
27.0 \\
28.2\end{array}$ & $\begin{array}{l}25.6 \\
27.0 \\
28.0 \\
30.6\end{array}$ & $\begin{array}{l}0.1144 \\
0.11144 \\
0.1152 \\
0.1163\end{array}$ & $\begin{array}{l}102.50 \\
104.90 \\
107.20 \\
112.02\end{array}$ & $\begin{array}{l}62.59 \\
82.37 \\
82.79 \\
83.18\end{array}$ & $\begin{array}{r}22.2 \\
7.6 \\
5.2 \\
3.0\end{array}$ & $\begin{array}{r}17.9 \\
6.1 \\
4.2\end{array}$ & $\begin{array}{l}51868 . \\
17955 \\
12321 . \\
7202 .\end{array}$ & $\begin{array}{l}69.30 \\
69.61 \\
69.45 \\
69.59\end{array}$ & $\begin{array}{l}69.89 \\
71.22 \\
71.81 \\
73.65\end{array}$ & $\begin{array}{l}0.55 \\
1.61 \\
2.35 \\
4.05\end{array}$ & $\begin{array}{l}35.38 \\
37.74 \\
39.69 \\
43.96\end{array}$ & $\begin{array}{l}6176 . \\
6135 . \\
6149 . \\
6137 .\end{array}$ & & $\begin{array}{l}0.7 \\
0.5 \\
0.6 \\
1.1\end{array}$ & $\begin{array}{l}167 . \\
155 . \\
148 . \\
133 .\end{array}$ \\
\hline $\begin{array}{l}\mathrm{A}-11-029 \mathrm{~A} \\
\mathrm{a}-11-030 \mathrm{~A} 1 \\
\mathrm{n}-11-031 \mathrm{n} 1 \\
\mathrm{n}-11-032 \mathrm{n} \\
\end{array}$ & $\begin{array}{l}110.97 \\
114.44 \\
117.12 \\
123.34\end{array}$ & $\begin{array}{l}28.2 \\
30.0 \\
31.5\end{array}$ & $\begin{array}{l}28.4 \\
30.1 \\
31.4 \\
34.8\end{array}$ & $\begin{array}{l}0.1410 \\
0.1409 \\
0.1414 \\
0.1443\end{array}$ & $\begin{array}{l}108.33 \\
111.34 \\
113.86 \\
119.50\end{array}$ & $\begin{array}{l}101.21 \\
100.84 \\
100.97 \\
102.42\end{array}$ & $\begin{array}{r}22.2 \\
7.6 \\
5.2 \\
3.0 \\
\end{array}$ & $\begin{array}{r}17.9 \\
6.1 \\
4.2 \\
2.4 \\
\end{array}$ & $\begin{array}{c}50547 . \\
17490 . \\
12045 . \\
7047 .\end{array}$ & $\begin{array}{l}67.35 \\
67.52 \\
67.56 \\
67.61\end{array}$ & $\begin{array}{l}68 . \\
69 \\
70 . \\
72 .\end{array}$ & $\begin{array}{l}0.68 \\
1.91 \\
2.79 \\
4.75 \\
\end{array}$ & $\begin{array}{r}43.27 \\
45.96 \\
48.16 \\
53.35 \\
\end{array}$ & $\begin{array}{l}75 \\
74 \\
74 \\
74 \\
\end{array}$ & $\begin{array}{l}7532 . \\
7269 . \\
7242 . \\
7127 .\end{array}$ & $\begin{array}{r}-0.3 \\
2.4 \\
2.6 \\
4.7\end{array}$ & $\begin{array}{l}166 . \\
155 . \\
147 . \\
134 .\end{array}$ \\
\hline
\end{tabular}


Taike C.3. Expertwental datis for R-11 condenoting on Tube $L$

\begin{tabular}{|c|c|c|c|c|c|c|c|c|c|c|c|c|c|c|c|c|c|}
\hline Rum No. & Ty & $\underset{(\min )}{\mathbf{P}}$ & $P_{\text {(mini) }}$ & $\underset{(\operatorname{spm})}{F_{c}}$ & $\begin{array}{l}T_{c} \\
\text { (eF) }\end{array}$ & $\left(m_{m} / m\right)$ & $F_{w}$ & 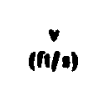 & Re & $T_{\text {win }}$ & $T_{\text {pom }}$ & $T_{w}$ & $\begin{array}{l}\Delta T \\
\boldsymbol{P}\end{array}$ & $\underset{(B i v / h)}{Q_{c}}$ & $\underset{\text { (Biv/h) }}{Q_{W}}$ & $\stackrel{\Delta}{(*)}$ & 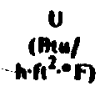 \\
\hline $\begin{array}{l}\mathrm{D}-11-0012 \\
\mathrm{R}-11-002 L \\
\mathrm{R}-11-0032 \\
\mathrm{a}-11-0042\end{array}$ & $\begin{array}{r}94.08 \\
97.35 \\
99.65 \\
104.68\end{array}$ & $\begin{array}{l}21.0 \\
22.2 \\
23.2 \\
25.2\end{array}$ & $\begin{array}{l}21.1 \\
22.4 \\
23.3 \\
25.5\end{array}$ & $\begin{array}{l}0.1419 \\
0.1410 \\
0.1418 \\
0.1417\end{array}$ & $\begin{array}{r}91.27 \\
94.44 \\
96.50 \\
101.05\end{array}$ & $\begin{array}{l}103.49 \\
102.55 \\
102.91 \\
102.40\end{array}$ & $\begin{array}{r}22.0 \\
7.6 \\
5.2 \\
3.0\end{array}$ & $\begin{array}{r}17.7 \\
6.1 \\
4.2 \\
2.4\end{array}$ & $\begin{array}{r}61520^{\circ} \\
21340 \\
14650^{\circ} \\
8520^{\circ}\end{array}$ & $\begin{array}{l}83.41 \\
83.08 \\
82.91 \\
82.64\end{array}$ & $\begin{array}{l}84.14 \\
85.13 \\
85.86 \\
87.61\end{array}$ & $\begin{array}{l}0.70 \\
2.03 \\
2.95 \\
4.97\end{array}$ & $\begin{array}{l}10.30 \\
13.24 \\
15.26 \\
19.55\end{array}$ & $\begin{array}{l}7843 . \\
7741 . \\
7746 . \\
7660 .\end{array}$ & $\begin{array}{l}7694 . \\
7716 . \\
7643 . \\
7436 .\end{array}$ & $\begin{array}{l}1.9 \\
0.3 \\
1.3 \\
2.9\end{array}$ & $\begin{array}{l}506 . \\
389 . \\
337 . \\
260 .\end{array}$ \\
\hline $\begin{array}{l}B-11-005 L \\
B-11-006 L \\
8-11-007 L \\
8-11-008 L\end{array}$ & $\begin{array}{r}92.30 \\
99.83 \\
103.88 \\
114.55\end{array}$ & $\begin{array}{l}20.4 \\
23.4 \\
24.9 \\
30.0\end{array}$ & $\begin{array}{l}20.4 \\
23.4 \\
25.1 \\
30.1\end{array}$ & $\begin{array}{l}0.2519 \\
0.2558 \\
0.2556 \\
0.2626\end{array}$ & $\begin{array}{r}89.90 \\
97.34 \\
101.03 \\
111.57\end{array}$ & $\begin{array}{l}184.02 \\
185.55 \\
184.77 \\
187.91\end{array}$ & $\begin{array}{r}21.8 \\
7.6 \\
5.2 \\
3.0\end{array}$ & $\begin{array}{r}17.6 \\
6.1 \\
4.2 \\
2.4\end{array}$ & $\begin{array}{c}50082 \\
17881 \\
12353 \\
7290\end{array}$ & $\begin{array}{l}67.68 \\
68.26 \\
68.20 \\
68.21\end{array}$ & $\begin{array}{l}69.02 \\
71.96 \\
73.45 \\
77.08\end{array}$ & $\begin{array}{l}1.311 \\
3.69 \\
5.24 \\
8.86\end{array}$ & $\begin{array}{l}23.95 \\
29.72 \\
33.05 \\
41.90\end{array}$ & $\begin{array}{l}13976 \\
13964 \\
13836 \\
13882\end{array}$ & $\begin{array}{l}14227 . \\
14025 \\
13621 . \\
13267 .\end{array}$ & $\begin{array}{r}-1.8 \\
-0.4 \\
1.6 \\
4.4\end{array}$ & $\begin{array}{l}388 . \\
312 . \\
278 . \\
220 .\end{array}$ \\
\hline $\begin{array}{l}8-11-0092 \\
B-11-0102 \\
R-11-0112 \\
8-11-012 L\end{array}$ & $\begin{array}{r}97.33 \\
98.23 \\
99.13 \\
101.35\end{array}$ & $\begin{array}{l}22.0 \\
22.2 \\
22.7 \\
23.7\end{array}$ & $\begin{array}{l}22.4 \\
22.7 \\
23.1 \\
24.0\end{array}$ & $\begin{array}{l}0.0708 \\
0.0700 \\
0.0696 \\
0.0696\end{array}$ & $\begin{array}{l}94.03 \\
94.90 \\
95.72 \\
97.59\end{array}$ & $\begin{array}{l}51.55 \\
50.89 \\
50.54 \\
50.45\end{array}$ & $\begin{array}{r}22.0 \\
7.6 \\
5.2 \\
3.0\end{array}$ & $\begin{array}{r}17.7 \\
6.1 \\
4.2 \\
2.4\end{array}$ & $\begin{array}{r}68518 \\
23513 \\
16086 \\
9302\end{array}$ & $\begin{array}{l}92.92 \\
92.00 \\
91.77 \\
91.49\end{array}$ & $\begin{array}{l}93.31 \\
93.05 \\
93.25 \\
93.95\end{array}$ & $\begin{array}{l}0.34 \\
1.03 \\
1.47 \\
2.45\end{array}$ & $\begin{array}{l}4.22 \\
5.71 \\
6.62 \\
6.63\end{array}$ & $\begin{array}{l}3891 . \\
3837 . \\
3807 \\
3790 .\end{array}$ & $\begin{array}{l}3770 . \\
3899 . \\
3807 . \\
3659 .\end{array}$ & $\begin{array}{r}3.1 \\
-1.6 \\
-0.0 \\
3.4\end{array}$ & $\begin{array}{l}613 . \\
447 . \\
332 . \\
292 .\end{array}$ \\
\hline $\begin{array}{l}8-11-013 L \\
i-11-014 L \\
D-11-015 L \\
8-11-016 L\end{array}$ & $\begin{array}{r}97.14 \\
98.23 \\
99.09 \\
101.68\end{array}$ & $\begin{array}{l}21.9 \\
22.2 \\
22.7 \\
23.7\end{array}$ & $\begin{array}{l}22.3 \\
22.7 \\
23.1 \\
24.2\end{array}$ & $\begin{array}{l}0.0702 \\
0.0693 \\
0.0693 \\
0.0703\end{array}$ & $\begin{array}{l}94.02 \\
94.96 \\
95.87 \\
98.07\end{array}$ & $\begin{array}{l}\mathbf{5 1 . 0 5} \\
\mathbf{5 0 . 3 8} \\
\mathbf{5 0 . 3 4} \\
\mathbf{5 0 . 9 7}\end{array}$ & $\begin{array}{r}22.0 \\
7.6 \\
5.2 \\
3.0\end{array}$ & $\begin{array}{r}17.7 \\
6.1 \\
4.2 \\
2.4\end{array}$ & $\begin{array}{r}68352 \\
23513 \\
16075 \\
9319\end{array}$ & $\begin{array}{l}92.70 \\
92.00 \\
91.70 \\
91.64\end{array}$ & $\begin{array}{l}93.10 \\
93.05 \\
93.20 \\
94.13\end{array}$ & $\begin{array}{l}0.36 \\
1.03 \\
1.48 \\
2.48\end{array}$ & $\begin{array}{l}4.24 \\
5.71 \\
6.64 \\
8.80\end{array}$ & $\begin{array}{l}3855 . \\
3799 . \\
3792 . \\
3827 .\end{array}$ & $\begin{array}{l}3923 . \\
3899 . \\
3844 . \\
3700 .\end{array}$ & $\begin{array}{r}-1.6 \\
-2.6 \\
-1.4 \\
3.3\end{array}$ & $\begin{array}{l}604 . \\
443 . \\
380 . \\
289 .\end{array}$ \\
\hline $\begin{array}{l}8-11-0172 \\
n-11-018 L \\
R-11-019 L \\
8-11-020 L\end{array}$ & $\begin{array}{r}95.38 \\
97.46 \\
98.82 \\
102.25\end{array}$ & $\begin{array}{l}21.2 \\
22.2 \\
22.7 \\
24.2\end{array}$ & $\begin{array}{l}21.6 \\
22.4 \\
23.0 \\
24.4\end{array}$ & $\begin{array}{l}0.1000 \\
0.0992 \\
0.0992 \\
0.0995\end{array}$ & $\begin{array}{l}92.70 \\
94.69 \\
95.83 \\
98.89\end{array}$ & $\begin{array}{l}72.89 \\
72.14 \\
72.07 \\
72.06\end{array}$ & $\begin{array}{r}22.0 \\
7.4 \\
5.2 \\
3.0\end{array}$ & $\begin{array}{r}17.7 \\
6.0 \\
4.2 \\
2.4\end{array}$ & $\begin{array}{r}65066 \\
21864 \\
15389 \\
6923\end{array}$ & $\begin{array}{l}88.34 \\
67.76 \\
87.61 \\
87.33\end{array}$ & $\begin{array}{l}88.89 \\
89.29 \\
89.72 \\
90.87\end{array}$ & $\begin{array}{l}0.50 \\
1.54 \\
2.12 \\
3.52\end{array}$ & $\begin{array}{r}6.77 \\
6.93 \\
10.15 \\
13.15\end{array}$ & $\begin{array}{l}5515 . \\
5445 \\
5430 \\
5407 .\end{array}$ & & $\begin{array}{r}0.5 \\
-4.6 \\
-1.3 \\
2.6\end{array}$ & $\begin{array}{l}542 . \\
405 . \\
356 . \\
273 .\end{array}$ \\
\hline $\begin{array}{l}\mathrm{R}-11-021 L \\
\mathrm{~B}-11-022 \mathrm{~L} \\
\mathrm{~B}-11-023 \mathrm{~L}\end{array}$ & $\begin{array}{r}94.40 \\
99.17 \\
101.93\end{array}$ & $\begin{array}{l}20.7 \\
22.7 \\
23.9\end{array}$ & $\begin{array}{l}21.2 \\
23.1 \\
24.3\end{array}$ & $\begin{array}{l}0.1833 \\
0.1842 \\
0.1853\end{array}$ & $\begin{array}{l}92.55 \\
97.04 \\
99.63\end{array}$ & $\begin{array}{l}133.60 \\
133.68 \\
134.15\end{array}$ & $\begin{array}{r}22.0 \\
7.4 \\
5.2\end{array}$ & $\begin{array}{r}17.7 \\
6.0 \\
4.2\end{array}$ & & $\begin{array}{l}79.23 \\
79.15 \\
79.00\end{array}$ & $\begin{array}{l}4 \\
9\end{array}$ & $\begin{array}{l}0.93 \\
2.68 \\
3.78\end{array}$ & $\begin{array}{l}14.68 \\
18.68 \\
21.04\end{array}$ & & $\begin{array}{l}0 . \\
8 . \\
8 .\end{array}$ & $\begin{array}{r}-1.2 \\
1.7 \\
2.7\end{array}$ & $\begin{array}{l}458 . \\
358 . \\
318 .\end{array}$ \\
\hline $\begin{array}{l}R-11-024 L \\
R-11-025 L \\
R-11-026 L \\
R-11-027 L\end{array}$ & $\begin{array}{l}97.69 \\
98.13 \\
98.50 \\
99.89\end{array}$ & $\begin{array}{l}22.2 \\
22.4 \\
22.5 \\
23.0\end{array}$ & $\begin{array}{l}22.5 \\
22.7 \\
22.8 \\
23.4\end{array}$ & $\begin{array}{l}0.0513 \\
0.0507 \\
0.0505 \\
0.0505\end{array}$ & $\begin{array}{l}93.56 \\
93.54 \\
93.75 \\
94.90\end{array}$ & $\begin{array}{l}37.36 \\
36.69 \\
36.73 \\
36.69\end{array}$ & $\begin{array}{r}22.0 \\
7.6 \\
5.2 \\
3.0\end{array}$ & $\begin{array}{r}17.7 \\
6.1 \\
4.2 \\
2.4\end{array}$ & $\begin{array}{r}69814 . \\
23953 . \\
16325 . \\
9399\end{array}$ & $\begin{array}{l}94.62 \\
93.78 \\
93.26 \\
92.70\end{array}$ & $\begin{array}{l}94.93 \\
94.55 \\
94.38 \\
94.57\end{array}$ & $\begin{array}{l}0.26 \\
0.77 \\
1.11 \\
1.87\end{array}$ & $\begin{array}{l}2.92 \\
3.97 \\
1.69 \\
6.26\end{array}$ & $\begin{array}{l}2819 . \\
2782 . \\
2768 . \\
2761 .\end{array}$ & & $\begin{array}{l}-3.0 \\
-5.1 \\
-4.2 \\
-1.4\end{array}$ & \\
\hline $\begin{array}{l}R-11-028 L \\
R-11-029 L \\
R-11-030 L \\
R-11-031 L\end{array}$ & $\begin{array}{r}96.45 \\
97.77 \\
98.90 \\
101.24\end{array}$ & $\begin{array}{l}21.7 \\
22.2 \\
22.7 \\
23.7\end{array}$ & $\begin{array}{l}22.0 \\
22.5 \\
23.0 \\
24.0\end{array}$ & $\begin{array}{l}0.0790 \\
0.0790 \\
0.0792 \\
0.0790\end{array}$ & $\begin{array}{l}93.49 \\
91.60 \\
95.52 \\
97.19\end{array}$ & $\begin{array}{l}57.52 \\
57.46 \\
57.56 \\
57.32\end{array}$ & $\begin{array}{r}22.0 \\
7.6 \\
5.2 \\
3.0\end{array}$ & $\begin{array}{r}17.7 \\
6.1 \\
4.2 \\
2.4\end{array}$ & $\begin{array}{r}67242 \\
23127 \\
15823 \\
9145\end{array}$ & $\begin{array}{l}24 \\
99 \\
22 \\
84\end{array}$ & $\begin{array}{l}91.68 \\
91.66 \\
91.93 \\
92.62\end{array}$ & $\begin{array}{l}0.39 \\
1.15 \\
1.69 \\
2.77\end{array}$ & $\begin{array}{r}4.99 \\
6.69 \\
7.82 \\
10.01\end{array}$ & $\begin{array}{l}7 . \\
5 . \\
6 .\end{array}$ & & $\begin{array}{r}2.2 \\
-0.6 \\
-1.1 \\
3.9\end{array}$ & $\begin{array}{l}579 . \\
431 . \\
369 . \\
286 .\end{array}$ \\
\hline $\begin{array}{l}R-11-032 L \\
-11-033 L \\
8-11-034 L \\
-11-035 L\end{array}$ & $\begin{array}{r}94.11 \\
96.08 \\
100.64 \\
106.61\end{array}$ & $\begin{array}{l}20.7 \\
22.4 \\
23.4 \\
26.0\end{array}$ & $\begin{array}{l}21.1 \\
22.7 \\
23.7 \\
26.3\end{array}$ & $\begin{array}{l}0.1584 \\
0.1592 \\
0.1592 \\
0.1614\end{array}$ & $\begin{array}{r}92.29 \\
96.05 \\
98.32 \\
103.92\end{array}$ & $\begin{array}{l}115.43 \\
115.65 \\
115.36 \\
116.33\end{array}$ & $\begin{array}{r}22.0 \\
7.6 \\
5.2 \\
3.0\end{array}$ & $\begin{array}{r}17.7 \\
6.1 \\
4.2 \\
2.4\end{array}$ & $\begin{array}{r}60327 \\
20958 \\
14404 \\
8405\end{array}$ & $\begin{array}{l}74 \\
47 \\
31 \\
11\end{array}$ & $\begin{array}{l}82.57 \\
83.77 \\
84.66 \\
86.73\end{array}$ & $\begin{array}{l}0.80 \\
2.29 \\
3.34 \\
5.62\end{array}$ & $\begin{array}{l}11.96 \\
15.46 \\
17.66 \\
22.69\end{array}$ & 7. & $\begin{array}{l}7 . \\
5 . \\
2 . \\
8 .\end{array}$ & $\begin{array}{l}0.1 \\
0.5 \\
0.1\end{array}$ & $\begin{array}{l}4 \\
3 \\
3 \\
2\end{array}$ \\
\hline $\begin{array}{l}8-11-0362 \\
=-11-0372 \\
Q-11-0362 \\
-11-0392\end{array}$ & $\begin{array}{r}95.38 \\
98.12 \\
100.26 \\
104.39\end{array}$ & $\begin{array}{l}21.4 \\
22.5 \\
23.4 \\
25.0\end{array}$ & $\begin{array}{l}21.6 \\
22.7 \\
23.6 \\
25.3\end{array}$ & $\begin{array}{l}0.1222 \\
0.1219 \\
0.1223 \\
0.1222\end{array}$ & $\begin{array}{r}93.34 \\
95.68 \\
97.74 \\
101.30\end{array}$ & $\begin{array}{l}88.97 \\
88.59 \\
68.69 \\
88.29\end{array}$ & $\begin{array}{r}22.0 \\
7.6 \\
5.2 \\
3.0\end{array}$ & $\begin{array}{r}17.7 \\
6.1 \\
4.2 \\
2.4\end{array}$ & $\begin{array}{l}63749 . \\
22069 . \\
15161 . \\
8809\end{array}$ & $\begin{array}{l}86.54 \\
66.18 \\
66.10 \\
85.86\end{array}$ & $\begin{array}{l}67.93 \\
69.69 \\
90.14\end{array}$ & $\begin{array}{l}0.62 \\
1.77 \\
2.59 \\
4.26\end{array}$ & $\begin{array}{r}8.51 \\
11.06 \\
12.86\end{array}$ & i. & a. & $\begin{array}{r}-0.6 \\
-0.1 \\
-0.7 \\
3.6\end{array}$ & 3 \\
\hline $\begin{array}{l}R-11-040 L \\
R-11-041 L \\
R-11-042 L \\
B-11-0432\end{array}$ & $\begin{array}{r}94.48 \\
100.26 \\
103.76 \\
112.26\end{array}$ & $\begin{array}{l}23.2 \\
24.7 \\
28.7\end{array}$ & $\begin{array}{l}21.3 \\
23.6 \\
25.1 \\
29.0\end{array}$ & $\begin{array}{l}0.2132 \\
0.2155 \\
0.2157 \\
0.2190\end{array}$ & $\begin{array}{r}92.16 \\
97.82 \\
101.43 \\
109.32\end{array}$ & $\begin{array}{r}155.42 \\
156.25 \\
155.84 \\
157.02\end{array}$ & $\begin{array}{r}21.8 \\
7.6 \\
5.2 \\
3.0\end{array}$ & $\begin{array}{r}17.6 \\
6.1 \\
4.2 \\
2.4\end{array}$ & $\begin{array}{l}19608 . \\
13521 . \\
7941 .\end{array}$ & $\begin{array}{l}75.66 \\
75.73 \\
75.68 \\
75.55\end{array}$ & $\begin{array}{l}76.78 \\
78.02 \\
80.09 \\
83.06\end{array}$ & $\begin{array}{l}1.08 \\
3.08 \\
4.39 \\
7.49\end{array}$ & $\begin{array}{l}18.26 \\
22.98 \\
25.88 \\
32.95\end{array}$ & $\begin{array}{l}11772 . \\
11752 . \\
11671 . \\
11634 .\end{array}$ & $\begin{array}{l}11789 . \\
1167 . \\
11394 . \\
11206 .\end{array}$ & $\begin{array}{r}-0.1 \\
0.7 \\
2.1 \\
3.7\end{array}$ & $\begin{array}{l}429 . \\
340 . \\
300 . \\
235 .\end{array}$ \\
\hline
\end{tabular}


Toble C.3 (cosettined)

\begin{tabular}{|c|c|c|c|c|c|c|c|c|c|c|c|c|c|c|c|c|c|}
\hline Rom No. & Pro & (psia) & Patiat) & $\left(\mathbf{s p m}_{e}\right)$ & $\boldsymbol{T}_{\mathbf{C}}$ & $\left(m_{m} / m\right)$ & $\underset{(\mathrm{BPm})}{F_{\mathrm{w}}}$ & $(m / 0)$ & Re & $T_{\min }$ & $T_{\text {mom }}$ & ${ }^{\Delta T_{W}}$ & $\begin{array}{c}\Delta T \\
\mathbf{P F}\end{array}$ & $\begin{array}{c}Q_{c} \\
\left(D_{u} / h\right)\end{array}$ & 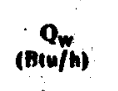 & (4) & 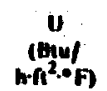 \\
\hline $\begin{array}{l}R-11-044 L \\
R-11-045 L \\
R-11-0462 \\
R-11-047 L\end{array}$ & $\begin{array}{r}92.03 \\
98.54 \\
102.63 \\
112.82\end{array}$ & $\begin{array}{l}20.0 \\
22.5 \\
24.2 . \\
29.0\end{array}$ & $\begin{array}{l}20.3 \\
22.9 \\
24.6 \\
29.3\end{array}$ & $\begin{array}{r}0.2321 \\
0.2343 \\
0.2360 \\
0.2404\end{array}$ & $\begin{array}{c}99.80 \\
96.13 \\
99.93 \\
109.97\end{array}$ & $\begin{array}{r}169.54 \\
170.14 \\
170.77 \\
172.31\end{array}$ & $\begin{array}{r}21.8 \\
7.6 \\
5.2 \\
3.0\end{array}$ & $\begin{array}{r}17.6 \\
6.1 \\
4.2 \\
2.4\end{array}$ & $\begin{array}{l}52046 \\
18458 . \\
12748 . \\
7554 .\end{array}$ & $\begin{array}{l}70.60 \\
70.92 \\
70.92 \\
71.26\end{array}$ & $\begin{array}{l}71.00 \\
74.30 \\
75.72 \\
79.50\end{array}$ & $\begin{array}{l}1.17 \\
3.37 \\
4.79 \\
0.24\end{array}$ & $\begin{array}{l}20.83 \\
25.93 \\
29.29 \\
37.44\end{array}$ & $\begin{array}{l}12880 \\
12824 \\
12807 \\
12758\end{array}$ & $\begin{array}{l}12778 \\
12762 \\
12429 \\
12327\end{array}$ & $\begin{array}{l}0.8 \\
0.5 \\
3.0 \\
3.4\end{array}$ & $\begin{array}{l}411 . \\
329 . \\
291 . \\
227 .\end{array}$ \\
\hline
\end{tabular}


Table C.4. Experimentsl datu for R-II condensing on Tube L-1

\begin{tabular}{|c|c|c|c|c|c|c|c|c|c|c|c|c|c|c|c|c|c|}
\hline Run No. & Pry & $\underset{\text { (psia) }}{P}$ & $\begin{array}{l}P_{\text {sat }} \\
\text { (piil) }\end{array}$ & $\underset{(\mathbf{s p e}}{\mathbf{F}_{\mathbf{c}}}$ & $\begin{array}{c}T_{c} \\
(\mathfrak{h})\end{array}$ & $\left(w_{m}^{m} / m\right)$ & $\underset{\text { (Epm) }}{F_{w}}$ & $(n / 2)$ & Re & $T_{\text {win }}$ & $T_{\text {proul }}$ & $\underset{\left(P T_{w}\right.}{\Delta T^{\prime}}$ & $\underset{\rho P}{\Delta r}$ & $\underset{(B u / h)}{Q_{c}}$ & $\begin{array}{c}Q_{w} \\
\left(B_{w} w / h\right)\end{array}$ & $\underset{(\%)}{\Delta}$ & 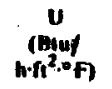 \\
\hline 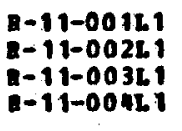 & $\begin{array}{r}98.21 \\
99.45 \\
100.48 \\
102.61\end{array}$ & $\begin{array}{l}22.2 \\
22.9 \\
23.2 \\
24.2\end{array}$ & $\begin{array}{l}22.7 \\
23.2 \\
23.7 \\
24.6\end{array}$ & $\begin{array}{l}0.0653 \\
0.0655 \\
0.0648 \\
0.0653\end{array}$ & $\begin{array}{l}93.81 \\
94.74 \\
95.68 \\
97.17\end{array}$ & $\begin{array}{l}47.50 \\
47.61 \\
47.10 \\
47.35\end{array}$ & $\begin{array}{r}22.0 \\
7.6 \\
5.0 \\
2.9\end{array}$ & $\begin{array}{r}17.7 \\
6.1 \\
4.0 \\
2.3\end{array}$ & $\begin{array}{l}69835 . \\
24090 . \\
15866 . \\
9219 .\end{array}$ & $\begin{array}{l}94.62 \\
94.20 \\
94.08 \\
93.76\end{array}$ & $\begin{array}{l}94.98 \\
95.14 \\
95.47 \\
96.11\end{array}$ & $\begin{array}{l}0.32 \\
0.94 \\
1.39 \\
2.35\end{array}$ & $\begin{array}{r}3.41 \\
4.78 \\
5.71 \\
7.68\end{array}$ & $\begin{array}{l}3581 . \\
3584 . \\
3542 . \\
3551 .\end{array}$ & $\begin{array}{l}3496 . \\
3574 . \\
3469 . \\
3394 .\end{array}$ & $\begin{array}{l}2.4 \\
0.3 \\
2.0 \\
4.4\end{array}$ & $\begin{array}{l}698 . \\
499 . \\
413 . \\
308 .\end{array}$ \\
\hline $\begin{array}{l}8-11-005 L 1 \\
8-11-00621 \\
8-11-007 L 1 \\
8-11-00821\end{array}$ & $\begin{array}{r}93.28 \\
98.80 \\
102.70 \\
110.92\end{array}$ & $\begin{array}{l}20.5 \\
22.7 \\
24.4 \\
28.0\end{array}$ & $\begin{array}{l}20.8 \\
23.0 \\
24.6 \\
28.3\end{array}$ & $\begin{array}{l}0.2156 \\
0.2173 \\
0.2158 \\
0.2184\end{array}$ & $\begin{array}{r}91.37 \\
96.48 \\
100.19 \\
107.92\end{array}$ & $\begin{array}{l}157.30 \\
157.77 \\
156.14 \\
156.80\end{array}$ & $\begin{array}{r}21.0 \\
7.6 \\
5.0 \\
3.0\end{array}$ & $\begin{array}{r}17.6 \\
6.1 \\
4.0 \\
2.4\end{array}$ & $\begin{array}{l}56409 . \\
19841 . \\
13161 . \\
8022 .\end{array}$ & $\begin{array}{l}76.94 \\
76.63 \\
76.52 \\
76.28\end{array}$ & $\begin{array}{l}78.07 \\
79.79 \\
81.19 \\
83.96\end{array}$ & $\begin{array}{l}1.09 \\
3.14 \\
4.65 \\
7.66\end{array}$ & $\begin{array}{l}15.77 \\
20.59 \\
23.84 \\
30.79\end{array}$ & $\begin{array}{l}11933 . \\
11888 \\
11709 \\
11638\end{array}$ & $\begin{array}{l}11887 . \\
11925 . \\
11599 . \\
11459 .\end{array}$ & $\begin{array}{r}0.4 \\
-0.3 \\
0.9 \\
1.5\end{array}$ & $\begin{array}{l}503 . \\
304: \\
327 . \\
251 .\end{array}$ \\
\hline $\begin{array}{l}8-11-009 L 1 \\
Q-11-01021 \\
8-11-011 L 1 \\
8-11-012 L 1\end{array}$ & $\begin{array}{r}97.83 \\
99.17 \\
99.97 \\
102.57\end{array}$ & $\begin{array}{l}22.5 \\
23.0 \\
23.4 \\
24.5\end{array}$ & $\begin{array}{l}22.6 \\
23.1 \\
23.4 \\
24.5\end{array}$ & $\begin{array}{l}0.0853 \\
0.0859 \\
0.0855 \\
0.0853\end{array}$ & $\begin{array}{l}94.12 \\
95.36 \\
96.09 \\
97.74\end{array}$ & $\begin{array}{l}62.04 \\
62.43 \\
62.08 \\
61.83\end{array}$ & $\begin{array}{r}22.0 \\
7.6 \\
5.2 \\
3.0\end{array}$ & $\begin{array}{r}17.7 \\
6.1 \\
4.2 \\
2.4\end{array}$ & $\begin{array}{l}68425 \\
23502 \\
16032 \\
9264\end{array}$ & $\begin{array}{l}92.76 \\
91.85 \\
91.32 \\
90.87\end{array}$ & $\begin{array}{l}93.22 \\
93.12 \\
93.12 \\
93.85\end{array}$ & $\begin{array}{l}0.41 \\
1.25 \\
1.78 \\
2.97\end{array}$ & $\begin{array}{r}4.84 \\
6.69 \\
7.75 \\
10.21\end{array}$ & $\begin{array}{l}4680 . \\
4702 . \\
4671 . \\
4637 .\end{array}$ & $\begin{array}{l}4504 . \\
4728 . \\
4605 . \\
4432 .\end{array}$ & $\begin{array}{r}3.8 \\
-0.5 \\
1.4 \\
4.4\end{array}$ & $\begin{array}{l}644 . \\
468 . \\
401 . \\
302 .\end{array}$ \\
\hline 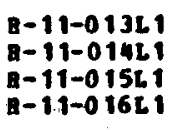 & $\begin{array}{r}92.97 \\
97.52 \\
100.87 \\
108.48\end{array}$ & $\begin{array}{l}20.5 \\
22.2 \\
23.7 \\
26.9\end{array}$ & $\begin{array}{l}20.7 \\
22.4 \\
23.8 \\
27.2\end{array}$ & $\begin{array}{l}0.1878 \\
0.1877 \\
0.1868 \\
0.1942\end{array}$ & $\begin{array}{r}90.59 \\
94.81 \\
9.0 .01 \\
105.06\end{array}$ & $\begin{array}{l}137.12 \\
136.45 \\
136.83 \\
139.84\end{array}$ & $\begin{array}{r}21.8 \\
7.6 \\
5.2 \\
3.0\end{array}$ & $\begin{array}{r}17.6 \\
6.1 \\
4.2 \\
2.4\end{array}$ & $\begin{array}{c}58030 \\
20358 \\
14024 \\
8222\end{array}$ & $\begin{array}{l}79.26 \\
78.89 \\
78.82 \\
78.77\end{array}$ & $\begin{array}{l}80.25 \\
61.63 \\
82.80 \\
85.46\end{array}$ & $\begin{array}{l}0.96 \\
2.73 \\
3.97 \\
6.69\end{array}$ & $\begin{array}{l}13.21 \\
17.26 \\
20.06 \\
26.36\end{array}$ & $\begin{array}{l}10406 . \\
10297 \\
10284 . \\
10411 .\end{array}$ & $\begin{array}{l}10430 . \\
10340 \\
10307 \\
10007\end{array}$ & $\begin{array}{r}-0.2 \\
-0.4 \\
-0.2 \\
3.9\end{array}$ & $\begin{array}{l}524 . \\
397 . \\
341 . \\
263 .\end{array}$ \\
\hline $\begin{array}{l}\mathrm{B}-11-017 \mathrm{~L} \\
\mathrm{R}-11-018 \mathrm{~L} \\
\mathrm{R}-11-019 \mathrm{~L} \\
\mathrm{~B}-11-02021\end{array}$ & $\begin{array}{r}97.43 \\
99.45 \\
101.01 \\
104.50\end{array}$ & $\begin{array}{l}22.2 \\
22.9 \\
23.7 \\
25.0\end{array}$ & $\begin{array}{l}22.4 \\
23.2 \\
23.9 \\
25.4\end{array}$ & $\begin{array}{l}0.1069 \\
0.1069 \\
0.1071 \\
0.1080\end{array}$ & $\begin{array}{r}94.30 \\
95.92 \\
97.34 \\
100.52\end{array}$ & $\begin{array}{l}77.79 \\
77.67 \\
77.72 \\
78.10\end{array}$ & $\begin{array}{r}22.0 \\
7.6 \\
5.2 \\
3.0\end{array}$ & $\begin{array}{r}17.7 \\
6.1 \\
4.2 \\
2.4\end{array}$ & $\begin{array}{c}66913 . \\
23033 \\
75773 . \\
9145 .\end{array}$ & $\begin{array}{l}90.75 \\
89.93 \\
89.65 \\
89.36\end{array}$ & $\begin{array}{l}91.31 \\
91.51 \\
91.94 \\
93.06\end{array}$ & $\begin{array}{l}0.51 \\
1.56 \\
2.28 \\
3.70\end{array}$ & $\begin{array}{r}6.39 \\
6.73 \\
10.22 \\
13.27\end{array}$ & $\begin{array}{l}5872 . \\
5848 . \\
5840 . \\
5843 .\end{array}$ & $\begin{array}{l}5621 . \\
5917 . \\
5911 . \\
5535 .\end{array}$ & $\begin{array}{r}4.3 \\
-1.2 \\
-1.2 \\
5.3\end{array}$ & $\begin{array}{l}611 . \\
445 . \\
380 . \\
293 .\end{array}$ \\
\hline $\begin{array}{l}a-11-022 L 1 \\
a-11-022 L 1 \\
a-11-023 L 1 \\
a-11-024 b 1\end{array}$ & $\begin{array}{r}93.54 \\
97.43 \\
100.17 \\
106.16\end{array}$ & $\begin{array}{l}20.7 \\
22.2 \\
23.2 \\
25.9\end{array}$ & $\begin{array}{l}20.9 \\
22.4 \\
23.5 \\
26.1\end{array}$ & $\begin{array}{l}0.1631 \\
0.1634 \\
0.1640 \\
0.1652\end{array}$ & $\begin{array}{r}91.41 \\
94.89 \\
97.34 \\
102.83\end{array}$ & $\begin{array}{l}118.97 \\
118.80 \\
119.00 \\
119.22\end{array}$ & $\begin{array}{r}22.0 \\
7.6 \\
5.2 \\
3.0\end{array}$ & $\begin{array}{r}17.7 \\
6.1 \\
4.2 \\
2.4\end{array}$ & $\begin{array}{c}60514 \\
21006 \\
19453 \\
8430\end{array}$ & $\begin{array}{l}81.98 \\
81.62 \\
81.57 \\
61.33\end{array}$ & $\begin{array}{l}82.84 \\
83.99 \\
84.96 \\
87.01\end{array}$ & $\begin{array}{l}0.83 \\
2.35 \\
3.38 \\
5.68\end{array}$ & $\begin{array}{l}11.13 \\
14.62 \\
16.91 \\
21.99\end{array}$ & $\begin{array}{l}9022 . \\
8967 . \\
8951 . \\
8902 .\end{array}$ & $\begin{array}{l}9099 . \\
8925 . \\
8761 . \\
8503 .\end{array}$ & $\begin{array}{r}-0.9 \\
0.5 \\
2.1 \\
4.5\end{array}$ & $\begin{array}{l}539 . \\
408 . \\
352 . \\
269 .\end{array}$ \\
\hline $\begin{array}{l}R-11-025 L 1 \\
B-11-026 L 1 \\
R-11-027 L 1 \\
B-11-028 L 1\end{array}$ & $\begin{array}{r}94.91 \\
97.90 \\
99.95 \\
104.68\end{array}$ & $\begin{array}{l}21.0 \\
22.2 \\
23.0 \\
25.4\end{array}$ & $\begin{array}{l}21.4 \\
22.6 \\
23.4 \\
25.5\end{array}$ & $\begin{array}{l}0.1384 \\
0.1370 \\
0.11374 \\
0.1380\end{array}$ & $\begin{array}{r}92.65 \\
95.41 \\
96.91 \\
101.13\end{array}$ & $\begin{array}{r}100.86 \\
99.55 \\
99.68 \\
99.77\end{array}$ & $\begin{array}{r}22.0 \\
7.6 \\
5.2 \\
3.0\end{array}$ & $\begin{array}{r}17.7 \\
6.1 \\
4.2 \\
2.4\end{array}$ & $\begin{array}{c}63117 . \\
21812 . \\
14950 \\
8672\end{array}$ & $\begin{array}{l}85.53 \\
85.06 \\
84.76 \\
84.26\end{array}$ & $\begin{array}{l}86.27 \\
87.07 \\
87.66 \\
89.08\end{array}$ & $\begin{array}{l}0.70 \\
2.03 \\
2.91 \\
1.80\end{array}$ & $\begin{array}{r}9.01 \\
11.84 \\
13.74 \\
18.01\end{array}$ & $\begin{array}{l}7636 . \\
7509 \\
7500 \\
7463\end{array}$ & $\begin{array}{l}7672 . \\
7669 . \\
7535 . \\
7173 .\end{array}$ & $\begin{array}{r}-0.5 \\
-2.1 \\
-0.5 \\
3.9\end{array}$ & $\begin{array}{l}563 . \\
422 . \\
363 . \\
276 .\end{array}$ \\
\hline $\begin{array}{l}R-11-029 L 1 \\
A-11-030 L 1 \\
B-11-03121 \\
A-11-032 L 1\end{array}$ & $\begin{array}{r}92.13 \\
98.64 \\
103.59 \\
113.91\end{array}$ & $\begin{array}{l}20.0 \\
22.7 \\
24.7 \\
29.7\end{array}$ & $\begin{array}{l}20.4 \\
23.0 \\
25.0 \\
29.8\end{array}$ & $\begin{array}{l}0.2493 \\
0.2507 \\
0.2543 \\
0.2598\end{array}$ & $\begin{array}{r}90.43 \\
96.55 \\
101.09 \\
111.08\end{array}$ & $\begin{array}{l}182.01 \\
182.02 \\
183.83 \\
185.96\end{array}$ & $\begin{array}{r}21.6 \\
7.6 \\
5.2 \\
3.0\end{array}$ & $\begin{array}{r}17.6 \\
6.1 \\
4.2 \\
2.4\end{array}$ & $\begin{array}{c}52973 \\
18776 \\
13002 \\
7675\end{array}$ & $\begin{array}{l}72.00 \\
72.11 \\
72.20 \\
72.18\end{array}$ & $\begin{array}{l}73.30 \\
75.71 \\
77.06 \\
81.03\end{array}$ & $\begin{array}{l}1.27 \\
3.59 \\
5.25 \\
8.84\end{array}$ & $\begin{array}{l}19.48 \\
24.92 \\
28.76 \\
37.30\end{array}$ & $\begin{array}{l}13826 \\
13715 \\
13770 \\
13749\end{array}$ & $\begin{array}{l}13834 . \\
13631 . \\
13617 \\
13234\end{array}$ & $\begin{array}{r}-0.1 \\
0.6 \\
1.1 \\
3.7\end{array}$ & $\begin{array}{l}472 . \\
366 . \\
318 . \\
245 .\end{array}$ \\
\hline $\begin{array}{l}\mathrm{B}-11-033 L 1 \\
R-11-034 \mathrm{~L}, \\
\mathrm{R}-11-035 \mathrm{~L} \\
\mathrm{~B}-11-036 \mathrm{~L}\end{array}$ & $\begin{array}{r}99.63 \\
100.46 \\
101.12 \\
102.68\end{array}$ & $\begin{array}{l}22.9 \\
23.4 \\
23.7 \\
24.2\end{array}$ & $\begin{array}{l}23.3 \\
23.6 \\
23.9 \\
24.6\end{array}$ & $\begin{array}{l}0.0523 \\
0.0523 \\
0.0523 \\
0.0523\end{array}$ & $\begin{array}{l}94.81 \\
95.65 \\
96.24 \\
97.50\end{array}$ & $\begin{array}{l}38.05 \\
38.02 \\
38.00 \\
37.95\end{array}$ & $\begin{array}{r}22.0 \\
7.6 \\
5.2 \\
3.0\end{array}$ & $\begin{array}{r}17.7 \\
6.1 \\
4.2 \\
2.4\end{array}$ & $\begin{array}{l}71404 . \\
24586 \\
96812 \\
9707\end{array}$ & $\begin{array}{l}96.79 \\
96.25 \\
96.03 \\
95.74\end{array}$ & $\begin{array}{l}97.10 \\
97.05 \\
97.16 \\
97.60\end{array}$ & $\begin{array}{l}0.27 \\
0.79 \\
1.13 \\
1.86\end{array}$ & $\begin{array}{l}2.68 \\
3.81 \\
4.52 \\
6.01\end{array}$ & $\begin{array}{l}2864 . \\
2859 . \\
2855 . \\
2846 .\end{array}$ & $\begin{array}{l}2965 . \\
2990 . \\
2912 . \\
2770 .\end{array}$ & $\begin{array}{r}-3.5 \\
-4.6 \\
-2.0 \\
2.7\end{array}$ & $\begin{array}{l}710 . \\
499 . \\
420 . \\
315 .\end{array}$ \\
\hline $\begin{array}{l}8-11-03728 \\
1-11-03821 \\
8-11-03911 \\
8-11-04021\end{array}$ & $\begin{array}{r}92.29 \\
98.21 \\
102.66 \\
111.25\end{array}$ & $\begin{array}{l}20.2 \\
22 .-5 \\
24.2 \\
28.2\end{array}$ & $\begin{array}{l}20.4 \\
22.7 \\
24.6 \\
28.5\end{array}$ & $\begin{array}{l}0.2297 \\
0.2301 \\
0.2316 \\
0.2341\end{array}$ & $\begin{array}{r}90.70 \\
96.09 \\
100.45 \\
108.67\end{array}$ & $\begin{array}{l}167.68 \\
167.11 \\
167.49 \\
168.01\end{array}$ & $\begin{array}{r}21.8 \\
7.6 \\
5.2 \\
3.0\end{array}$ & $\begin{array}{l}17.6 \\
6.1 \\
4.2 \\
2.4\end{array}$ & $\begin{array}{c}54566 . \\
19267 . \\
13339 \\
7831 .\end{array}$ & $\begin{array}{l}74.31 \\
74.24 \\
74.41 \\
74.21\end{array}$ & $\begin{array}{l}75.52 \\
77.57 \\
79.24 \\
82.19\end{array}$ & $\begin{array}{l}1.17 \\
3.32 \\
4.82 \\
7.95\end{array}$ & $\begin{array}{l}17.37 \\
22.31 \\
25.83 \\
33.05\end{array}$ & $\begin{array}{l}12735 \\
12601 \\
12560 \\
12464\end{array}$ & $\begin{array}{l}12757 . \\
12584 . \\
12494 . \\
11897 .\end{array}$ & $\begin{array}{r}-0.2 \\
0.1 \\
0.5 \\
4.5\end{array}$ & $\begin{array}{l}488 . \\
376 . \\
323 . \\
251 .\end{array}$ \\
\hline
\end{tabular}




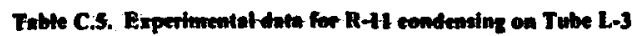

\begin{tabular}{|c|c|c|c|c|c|c|c|c|c|c|c|c|c|c|c|c|c|}
\hline Run No. & $T^{T}$ & 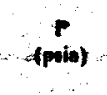 & $P_{\operatorname{sen}}$ & $F_{c}$ & $\boldsymbol{r}_{\mathrm{c}}$ & $\left(1 b_{m}^{m} / h\right)$ & $\underset{(\mathrm{EPm})}{F_{w}}$ & $(n / 1)$ & Re & $T_{\text {woin }}$ & $T_{\text {prout }}$ & $\begin{array}{l}\Delta \mathbf{T}_{w} \\
\boldsymbol{P}^{\prime} \boldsymbol{r}\end{array}$ & $\begin{array}{l}\Delta \mathbf{T} \\
(\boldsymbol{P} \mathbf{F})\end{array}$ & $\underset{(B+u / h)}{\mathbf{Q}_{\mathrm{c}}}$ & $\mathbf{Q}_{\mathbf{w}}$ & (4) & 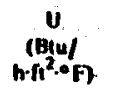 \\
\hline $\begin{array}{l}\mathrm{B}-11-00.123 \\
\mathrm{n}-11-002 \mathrm{~s} \\
\mathrm{n}-11-00.3 \mathrm{~L} \\
\mathrm{n}-11-004 \mathrm{~L}\end{array}$ & $\begin{array}{r}94.79 \\
97.90 \\
100.17 \\
105.06\end{array}$ & $\begin{array}{l}20.9 \\
22.2 \\
23.0 \\
25.2\end{array}$ & $\begin{array}{l}21.4 \\
22.6 \\
23.5 \\
25.6\end{array}$ & $\begin{array}{l}0.1350 \\
0.1352 \\
0.1357 \\
0.1360\end{array}$ & $\begin{array}{r}92.51 \\
95.23 \\
97.46 \\
101.76\end{array}$ & $\begin{array}{l}98.37 \\
98.28 \\
98.46 \\
98.25\end{array}$ & $\begin{array}{r}22.0 \\
7.5 \\
5.2 \\
3.0\end{array}$ & $\begin{array}{r}17.7 \\
6.0 \\
4.2 \\
2.4\end{array}$ & $\begin{array}{l}63438 . \\
21652 . \\
15100 . \\
8787 .\end{array}$ & $\begin{array}{l}86.10 \\
85.56 \\
85.64 \\
85.40\end{array}$ & $\begin{array}{l}86.02 \\
87.57 \\
88.47 \\
90.17\end{array}$ & $\begin{array}{l}0.67 \\
2.02 \\
2.84 \\
4.75\end{array}$ & $\begin{array}{r}6.33 \\
11.34 \\
13.12 \\
17.28\end{array}$ & $\begin{array}{l}7449 . \\
7414 . \\
7406 . \\
7346 .\end{array}$ & $\begin{array}{l}7320 . \\
7557 . \\
7353 . \\
7105 .\end{array}$ & $\begin{array}{r}1.7 \\
-1.9 \\
0.7 \\
3.3\end{array}$ & $\begin{array}{l}595 . \\
435 . \\
375 . \\
283 .\end{array}$ \\
\hline $\begin{array}{l}8-11-005 \mathrm{~L} \\
\mathrm{R}-11-006 \mathrm{~L} \\
\mathrm{R}-11-007 \mathrm{~L} \\
\mathrm{~g}-11-008 \mathrm{~L} 3\end{array}$ & $\begin{array}{r}97.62 \\
98.92 \\
99.87 \\
101.89\end{array}$ & $\begin{array}{l}22.2 \\
22.7 \\
23.0 \\
23.9\end{array}$ & $\begin{array}{l}22.5 \\
23.0 \\
23.4 \\
24.2\end{array}$ & $\begin{array}{l}0.0827 \\
0.0822 \\
0.0843 \\
0.0794\end{array}$ & $\begin{array}{l}94.07 \\
94.46 \\
94.99 \\
96.48\end{array}$ & $\begin{array}{l}60.16 \\
59.82 \\
59.10 \\
57.66\end{array}$ & $\begin{array}{r}22.2 \\
7.6 \\
5.2 \\
3.0\end{array}$ & $\begin{array}{r}17.9 \\
6.1 \\
4.2 \\
2.4\end{array}$ & $\begin{array}{l}69148 . \\
23575 \\
16108 \\
9270\end{array}$ & $\begin{array}{l}92.90 \\
92.15 \\
91.77 \\
91.00\end{array}$ & $\begin{array}{l}93.34 \\
93.36 \\
93.50 \\
93.83\end{array}$ & $\begin{array}{l}0.40 \\
1.19 \\
1.71 \\
2.82\end{array}$ & $\begin{array}{l}4.50 \\
6.16 \\
7.18 \\
9.48\end{array}$ & $\begin{array}{l}4540 . \\
4507 . \\
4447 . \\
4328 .\end{array}$ & $\begin{array}{l}4379 . \\
4505 \\
4437 \\
4211 .\end{array}$ & $\begin{array}{l}3.5 \\
0.1 \\
0.2 \\
2.7\end{array}$ & $\begin{array}{l}671 . \\
487 . \\
412 . \\
304 .\end{array}$ \\
\hline $\begin{array}{l}8-11-00953 \\
n-11-010 \mathrm{~s} \\
8-11-011 \mathrm{~s} \\
\mathrm{~B}-11-012 \mathrm{~s}\end{array}$ & $\begin{array}{r}92.44 \\
99.57 \\
104.07 \\
113.58\end{array}$ & $\begin{array}{l}20.0 \\
22.9 \\
24.9 \\
29.2\end{array}$ & $\begin{array}{l}20.5 \\
23.3 \\
25.2 \\
29.6\end{array}$ & $\begin{array}{l}0.2507 \\
0.2526 \\
0.2549 \\
0.2581\end{array}$ & $\begin{array}{r}90.52 \\
97.27 \\
101.61 \\
110.43\end{array}$ & $\begin{array}{l}183.03 \\
183.22 \\
184.17 \\
184.92\end{array}$ & $\begin{array}{r}22.0 \\
7.6 \\
5.2 \\
3.0\end{array}$ & $\begin{array}{r}17.7 \\
6.1 \\
4.2 \\
2.4\end{array}$ & $\begin{array}{l}54439 \\
19172 \\
13237 \\
7779\end{array}$ & $\begin{array}{l}73.39 \\
73.69 \\
73.57 \\
73.26\end{array}$ & $\begin{array}{l}74.68 \\
77.36 \\
78.88 \\
82.08\end{array}$ & $\begin{array}{l}1.26 \\
3.66 \\
5.30 \\
8.80\end{array}$ & $\begin{array}{l}18.40 \\
24.05 \\
27.85 \\
35.91\end{array}$ & $\begin{array}{l}3698 . \\
3793 . \\
3787 . \\
3678:\end{array}$ & $\begin{array}{l}13829 . \\
3862 . \\
3752 . \\
3160 .\end{array}$ & $\begin{array}{r}0.5 \\
-0.5 \\
0.3 \\
3.7\end{array}$ & $\begin{array}{l}502 . \\
381 . \\
329 . \\
253 .\end{array}$ \\
\hline $\begin{array}{l}8-11-0+3 L 3 \\
R-11-0.14 L 3 \\
R-11-0.5 L 3 \\
8-11-0.16 L 3\end{array}$ & $\begin{array}{r}93.64 \\
97.69 \\
100.44 \\
106.30\end{array}$ & $\begin{array}{l}20.5 \\
22.2 \\
23.2 \\
25.9\end{array}$ & $\begin{array}{l}20.9 \\
22.5 \\
23.6 \\
26.2\end{array}$ & $\begin{array}{l}0.1692 \\
0.1684 \\
0.1683 \\
0.1680\end{array}$ & $\begin{array}{r}92.02 \\
95.63 \\
96.13 \\
103.39\end{array}$ & $\begin{array}{l}123.33 \\
122.32 \\
121.97 \\
121.15\end{array}$ & $\begin{array}{r}22.0 \\
7.6 \\
5.2\end{array}$ & $\begin{array}{r}17.7 \\
6.1 \\
4.2 \\
2.4\end{array}$ & $\begin{array}{l}60677 \\
21083 \\
14505 \\
8467\end{array}$ & $\begin{array}{l}82.19 \\
61.89 \\
81.81 \\
61.65\end{array}$ & $\begin{array}{l}83.07 \\
84.33 \\
85.32 \\
87.42\end{array}$ & $\begin{array}{l}0.85 \\
2.43 \\
3.50 \\
5.76\end{array}$ & $\begin{array}{l}11.01 \\
14.59 \\
16.88 \\
21.77\end{array}$ & $\begin{array}{l}9352 . \\
9229 . \\
9172 . \\
9044 .\end{array}$ & $\begin{array}{l}9318 . \\
9202 . \\
9077 . \\
6622 .\end{array}$ & $\begin{array}{l}0.4 \\
0.3 \\
1.0 \\
4.7\end{array}$ & $\begin{array}{l}565 . \\
421 . \\
361 . \\
276 .\end{array}$ \\
\hline $\begin{array}{l}8-11-017 L 3 \\
8-11-0.023 \\
8-11-019[3 \\
8-11-02063\end{array}$ & $\begin{array}{r}98.00 \\
99.13 \\
100.13 \\
102.27\end{array}$ & $\begin{array}{l}22.2 \\
21.5 \\
23.2 \\
24.0\end{array}$ & $\begin{array}{l}22.6 \\
23.1 \\
23.5 \\
24.4\end{array}$ & $\begin{array}{l}0.0673 \\
0.0669 \\
0.0660 \\
0.0665\end{array}$ & $\begin{array}{l}94.55 \\
95.34 \\
96.37 \\
98.09\end{array}$ & $\begin{array}{l}48.96 \\
48.62 \\
47.95 \\
48.18\end{array}$ & $\begin{array}{r}22.2 \\
7.6 \\
5.2 \\
3.0\end{array}$ & $\begin{array}{r}17.9 \\
6.1 \\
4.2 \\
2.4\end{array}$ & $\begin{array}{l}70288 \\
23994 . \\
16435 \\
9543\end{array}$ & $\begin{array}{r}94.39 \\
93.83 \\
93.71 \\
93.55\end{array}$ & $\begin{array}{l}94.75 \\
94.80 \\
95.13 \\
95.87\end{array}$ & $\begin{array}{l}0.32 \\
0.97 \\
1.42 \\
2.32\end{array}$ & $\begin{array}{l}3.43 \\
4.82 \\
5.72 \\
7.56\end{array}$ & $\begin{array}{l}3693 . \\
3662 . \\
3607 . \\
3615 .\end{array}$ & $\begin{array}{l}3494 . \\
3672 . \\
3668 . \\
3465\end{array}$ & $\begin{array}{r}5.4 \\
-0.3 \\
-1.7 \\
4.1\end{array}$ & $\begin{array}{l}716 . \\
506 . \\
420 . \\
318 .\end{array}$ \\
\hline $\begin{array}{l}8-11-021 L 3 \\
\mathrm{~B}-1: 1-022 \mathrm{~s} \\
\mathrm{~B}-11-023 \mathrm{~L} \\
\mathrm{~B}-11-024 \mathrm{~L}\end{array}$ & $\begin{array}{r}93.40 \\
99.19 \\
103.33 \\
111.20\end{array}$ & $\begin{array}{l}20.4 \\
22.7 \\
24.5 \\
28.0\end{array}$ & $\begin{array}{l}20.8 \\
23.1 \\
24.9\end{array}$ & $\begin{array}{l}0.2173 \\
0.2179 \\
0.2188 \\
0.2212\end{array}$ & $\begin{array}{r}91.87 \\
97.15 \\
101.18 \\
108.43\end{array}$ & $\begin{array}{l}158.41 \\
158.06 \\
158.17 \\
158.76\end{array}$ & $\begin{array}{r}22.0 \\
7.6 \\
5.2 \\
3.0\end{array}$ & $\begin{array}{l}6.1 \\
4.2 \\
2.4\end{array}$ & $\begin{array}{c}57514 . \\
20135 . \\
13949 . \\
8170 .\end{array}$ & $\begin{array}{l}77.76 \\
77.81 \\
78.11 \\
77.86\end{array}$ & $\begin{array}{l}78.87 \\
80.94 \\
82.64\end{array}$ & $\begin{array}{l}1.07 \\
3.12 \\
4.52 \\
7.48\end{array}$ & $\begin{array}{l}15.08 \\
19.81 \\
22.95 \\
29.60\end{array}$ & 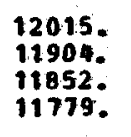 & $\begin{array}{l}1777 . \\
1830 . \\
1734 . \\
1200 .\end{array}$ & $\begin{array}{l}2.0 \\
0.6 \\
1.0 \\
4.9\end{array}$ & $\begin{array}{l}530 . \\
399 . \\
3163 . \\
265 .\end{array}$ \\
\hline $\begin{array}{l}8-11-0.25 \mathrm{~L} \\
\mathrm{~B}-11-026 \mathrm{z} \\
8-11-027 \mathrm{~L} \\
8-11-028 \mathrm{~s}\end{array}$ & $\begin{array}{r}96.00 \\
99.05 \\
101.01 \\
104.97\end{array}$ & $\begin{array}{l}21.7 \\
22.7 \\
23.5 \\
25.2\end{array}$ & $\begin{array}{l}22.2 \\
23.1 \\
23.9 \\
25.6\end{array}$ & $\begin{array}{l}0.1124 \\
0.1123 \\
0.1123 \\
0.1128\end{array}$ & $\begin{array}{r}94.39 \\
96.33 \\
98.11 \\
101.72\end{array}$ & $\begin{array}{l}81.74 \\
81.57 \\
81.40 \\
81.51\end{array}$ & $\begin{array}{r}22.2 \\
7.6 \\
5.2 \\
3.0\end{array}$ & $\begin{array}{r}17.9 \\
6.1 \\
4.2 \\
2.4\end{array}$ & $\begin{array}{l}66913 . \\
22876 . \\
15723 \\
9140\end{array}$ & $\begin{array}{l}89.95 \\
89.30 \\
89.33 \\
89.21\end{array}$ & $\begin{array}{l}90.54 \\
90.95 \\
91.71 \\
93.15\end{array}$ & $\begin{array}{l}0.55 \\
1.63 \\
2.36 \\
3.93\end{array}$ & $\begin{array}{r}6.56 \\
8.93 \\
10.49 \\
13.79\end{array}$ & $\begin{array}{l}6175 . \\
6144 . \\
6117 . \\
6095 .\end{array}$ & $\begin{array}{l}6049 . \\
6185 . \\
6120 . \\
5871 .\end{array}$ & $\begin{array}{r}2.0 \\
-0.7 \\
-0.1 \\
3.7\end{array}$ & $\begin{array}{l}626 . \\
458 . \\
388 . \\
294 .\end{array}$ \\
\hline $\begin{array}{l}B-11-0.29 L 3 \\
R-11-0.30 L 3 \\
R-11-031 L 3 \\
B-11-0.32 L 3\end{array}$ & $\begin{array}{r}92.61 \\
97.67 \\
100.87 \\
108.18\end{array}$ & $\begin{array}{l}20.2 \\
22.0 \\
23.4 \\
26.5\end{array}$ & $\begin{array}{l}20.5 \\
22.5 \\
23.8 \\
27.0\end{array}$ & $\begin{array}{l}0.1932 \\
0.1936 \\
0.1939 \\
0.1952\end{array}$ & $\begin{array}{r}90.78 \\
95.46 \\
98.34 \\
105.04\end{array}$ & $\begin{array}{l}141.04 \\
140.68 \\
140.55 \\
140.59\end{array}$ & $\begin{array}{r}22.0 \\
7.6 \\
5.2 \\
3.0\end{array}$ & $\begin{array}{r}17.7 \\
6.1 \\
4.2 \\
2.4\end{array}$ & $\begin{array}{c}58340 \\
20362 . \\
14033 . \\
8208\end{array}$ & $\begin{array}{l}78.95 \\
78.87 \\
78.84\end{array}$ & $\begin{array}{l}79.95 \\
81.68 \\
82.87 \\
85.37\end{array}$ & $\begin{array}{l}0.96 \\
2.80 \\
4.02 \\
6.79\end{array}$ & $\begin{array}{l}6 \\
0 \\
1\end{array}$ & $\begin{array}{l}\text { 8. } \\
\text { 5. } \\
1 .\end{array}$ & $\begin{array}{l}0 . \\
2 . \\
1 .\end{array}$ & $\begin{array}{r}1.3 \\
-0.2 \\
1.4\end{array}$ & $\begin{array}{l}341 . \\
406 . \\
351 . \\
266 .\end{array}$ \\
\hline $\begin{array}{l}8-11-033 L 3 \\
R-11-034 L 3 \\
8-11-035 L 3 \\
B-11-036 L 3\end{array}$ & $\begin{array}{r}98.56 \\
99.37 \\
100.15 \\
101.85\end{array}$ & $\begin{array}{l}22.4 \\
22.7 \\
22.9 \\
23.9\end{array}$ & $\begin{array}{l}22.9 \\
23.2 \\
23.5 \\
24.2\end{array}$ & $\begin{array}{l}0.0533 \\
0.0531 \\
0.0531 \\
0.0531\end{array}$ & $\begin{array}{l}93.56 \\
94.02 \\
94.96 \\
96.35\end{array}$ & $\begin{array}{l}38.02 \\
38.64 \\
38.61 \\
38.56\end{array}$ & $\begin{array}{r}22.2 \\
7.6 \\
5.2 \\
3.0\end{array}$ & $\begin{array}{r}17.9 \\
6.1 \\
4.2 \\
2.4\end{array}$ & $\begin{array}{c}71387 . \\
24352 . \\
16675 \\
9631 .\end{array}$ & $\begin{array}{l}95.81 \\
95.25 \\
95.14 \\
94.86\end{array}$ & $\begin{array}{l}96.11 \\
96.04 \\
96.28 \\
96.77\end{array}$ & $\begin{array}{l}0.26 \\
0.79 \\
1.14 \\
1.91\end{array}$ & $\begin{array}{l}2.60 \\
3.73 \\
4.44 \\
6.04\end{array}$ & 5. & $\begin{array}{l}2875 . \\
2979 . \\
2942 . \\
2851 .\end{array}$ & $\begin{array}{r}1.7 \\
-2.4 \\
-1.3 \\
1.5\end{array}$ & $\begin{array}{l}749 \\
519 \\
435 \\
319\end{array}$ \\
\hline $\begin{array}{l}R-11-037 L 3 \\
R-11-038 L 3 \\
B-11-039 L 3 \\
R-11-040 L 3 \\
\end{array}$ & $\begin{array}{r}92.57 \\
99.09 \\
103.50 \\
111.88 \\
\end{array}$ & $\begin{array}{l}20.7 \\
22.7 \\
24.7 \\
28.4 \\
\end{array}$ & $\begin{array}{l}20.5 \\
23.1 \\
24.9 \\
28.8 \\
\end{array}$ & $\begin{array}{l}0.2315 \\
0.2323 \\
0.2346 \\
0.2362 \\
\end{array}$ & $\begin{array}{r}90.86 \\
96.87 \\
101.18 \\
109.04 \\
\end{array}$ & $\begin{array}{l}168.94 \\
168.61 \\
169.57 \\
169.43 \\
\end{array}$ & $\begin{array}{r}22.0 \\
7.6 \\
5.2 \\
3.0 \\
\end{array}$ & $\begin{array}{r}17.7 \\
6.1 \\
4.2 \\
2.4 \\
\end{array}$ & $\begin{array}{r}55977 . \\
19676 . \\
13626 . \\
8000 . \\
\end{array}$ & $\begin{array}{l}75.59 \\
75.86 \\
76.06 \\
75.91 \\
\end{array}$ & $\begin{array}{l}76.78 \\
79.23 \\
80.94 \\
83.80 \\
\end{array}$ & $\begin{array}{l}1.15 \\
3.35 \\
4.87 \\
7.95 \\
\end{array}$ & $\begin{array}{r}16.39 \\
21.55 \\
25.00 \\
31.99 \\
\end{array}$ & $\begin{array}{l}12826 \\
12700 \\
12703 \\
12559\end{array}$ & $\begin{array}{l}12633 . \\
12698 . \\
12642 . \\
11897 \\
\end{array}$ & $\begin{array}{l}1.5 \\
0.0 \\
0.5 \\
5.3 \\
\end{array}$ & $\begin{array}{l}520 . \\
392 . \\
330 . \\
261 . \\
\end{array}$ \\
\hline
\end{tabular}


Tabte C.6. Exporimentel duta for R-11 condeming on Tube L.

\begin{tabular}{|c|c|c|c|c|c|c|c|c|c|c|c|c|c|c|c|c|c|}
\hline Run No. & Pค & $\underset{(\text { prin })}{P}$ & (prial) $^{\mathbf{P}_{\text {pria }}}$ & $\underset{(\mathrm{Epm})}{F_{\mathrm{e}}}$ & $\begin{array}{l}T_{c} \\
(-F)\end{array}$ & $\left(1 b_{m}^{m} / h\right)$ & $\underset{(\mathbf{B p m})}{\mathbf{F}_{\mathbf{w}}}$ & (ii/2) & Re & $T_{w, i n}$ & pout & $\underset{P F}{\Delta T_{W}}$ & $\begin{array}{c}\Delta T \\
\text { PF) }\end{array}$ & $\underset{(B+w / h)}{Q_{c}}$ & $\underset{(B+u / h)}{Q_{W}}$ & $\underset{\text { (क) }}{\Delta}$ & 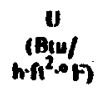 \\
\hline $\begin{array}{l}R-11-001 L \\
R-11-002 L \\
R-11-003 L \\
B-11-004 L\end{array}$ & $\begin{array}{r}99.99 \\
103.22 \\
105.36 \\
110.10\end{array}$ & $\begin{array}{l}23.0 \\
24.4 \\
25.3 \\
27.4\end{array}$ & $\begin{array}{l}23.5 \\
24.6 \\
25.8 \\
27.9\end{array}$ & $\begin{array}{l}0.1310 \\
0.1310 \\
0.1310 \\
0.1303\end{array}$ & $\begin{array}{r}97.17 \\
100.31 \\
102.42 \\
106.49\end{array}$ & $\begin{array}{l}95.04 \\
94.73 \\
94.54 \\
93.69\end{array}$ & $\begin{array}{r}22.2 \\
7.6 \\
5.2 \\
3.0\end{array}$ & $\begin{array}{r}19.9 \\
6.8 \\
4.7 \\
2.7\end{array}$ & $\begin{array}{c}69450 \\
24023 . \\
16552 . \\
9634\end{array}$ & $\begin{array}{l}91.21 \\
91.51 \\
91.72 \\
91.54\end{array}$ & $\begin{array}{l}91.88 \\
93.39 \\
94.41 \\
96.15\end{array}$ & $\begin{array}{l}0.62 \\
1.89 \\
2.69 \\
4.62\end{array}$ & $\begin{array}{r}8.45 \\
10.77 \\
12.29 \\
16.25\end{array}$ & $\begin{array}{l}7151 . \\
7099 . \\
7066 . \\
6961 .\end{array}$ & $\begin{array}{l}6867 . \\
7158 . \\
6975 \\
6898\end{array}$ & $\begin{array}{r}4.0 \\
-0.8 \\
1.3 \\
0.9\end{array}$ & $\begin{array}{l}563 . \\
438 . \\
382 . \\
285 .\end{array}$ \\
\hline $\begin{array}{l}R-11-005 L \\
R-11-006 L \\
R-11-007 L \\
R-11-008 L\end{array}$ & $\begin{array}{r}99.85 \\
100.19 \\
100.46 \\
101.81\end{array}$ & $\begin{array}{l}23.2 \\
23.4 \\
23.4 \\
23.49\end{array}$ & $\begin{array}{l}23.4 \\
23.5 \\
23.6 \\
24.2\end{array}$ & $\begin{array}{l}0.0489 \\
0.0487 \\
0.0483 \\
0.0487\end{array}$ & $\begin{array}{l}94.69 \\
94.89 \\
95.23 \\
96.89\end{array}$ & $\begin{array}{l}35.56 \\
35.40 \\
35.08 \\
35.33\end{array}$ & $\begin{array}{r}22.2 \\
7.6 \\
5.2 \\
3.0\end{array}$ & $\begin{array}{r}19.9 \\
6.8 \\
4.7 \\
2.7\end{array}$ & $\begin{array}{l}74055 \\
25200 \\
17180 \\
9908\end{array}$ & $\begin{array}{l}97.28 \\
96.51 \\
96.03 \\
95.67\end{array}$ & $\begin{array}{l}97.54 \\
97.22 \\
97.05 \\
97.35\end{array}$ & $\begin{array}{l}0.22 \\
0.70 \\
1.01 \\
1.70\end{array}$ & $\begin{array}{l}2.44 \\
3.33 \\
3.92 \\
5.30\end{array}$ & $\begin{array}{l}2676 \text { : } \\
2663 \text {. } \\
2638 . \\
2653 .\end{array}$ & $\begin{array}{l}2429 . \\
2657 . \\
2620 \\
2536\end{array}$ & $\begin{array}{l}9.2 \\
0.2 \\
0.7 \\
4.4\end{array}$ & $\begin{array}{l}729 . \\
532 . \\
448 . \\
333 .\end{array}$ \\
\hline $\begin{array}{l}\mathrm{R}-11-009 \mathrm{~L} \\
\mathrm{R}-11-010 \mathrm{~L} \\
\mathrm{R}-11-0,11 \mathrm{~L} \\
\mathrm{a}-11-012 \mathrm{~L}\end{array}$ & $\begin{array}{l}100.15 \\
101.43 \\
102.18 \\
105.26\end{array}$ & $\begin{array}{l}23.5 \\
24.0 \\
24.5 \\
25.7\end{array}$ & $\begin{array}{l}23.5 \\
24.1 \\
24.5 \\
25.7\end{array}$ & $\begin{array}{l}0.0877 \\
0.0881 \\
0.0879 \\
0.0883\end{array}$ & $\begin{array}{r}96.53 \\
97.55 \\
98.42 \\
100.99\end{array}$ & $\begin{array}{l}63.65 \\
63.89 \\
63.69 \\
63.82\end{array}$ & $\begin{array}{r}22.2 \\
7.6 \\
5.2 \\
3.0\end{array}$ & $\begin{array}{r}19.9 \\
6.8 \\
4.7 \\
2.7\end{array}$ & $\begin{array}{c}72240 . \\
24653 \\
16862 \\
9745\end{array}$ & $\begin{array}{l}94.60 \\
94.11 \\
93.80 \\
93.35\end{array}$ & $\begin{array}{l}95.25 \\
95.38 \\
95.64 \\
96.39\end{array}$ & $\begin{array}{l}0.41 \\
1.27 \\
1.84 \\
3.06\end{array}$ & $\begin{array}{r}5.13 \\
6.68 \\
7.77 \\
10.40\end{array}$ & $\begin{array}{l}4788 . \\
4799 . \\
477 . \\
4771 .\end{array}$ & $\begin{array}{l}4556 . \\
4796 . \\
4758 . \\
4575 .\end{array}$ & $\begin{array}{l}4.9 \\
0.1 \\
0.4 \\
4.1\end{array}$ & $\begin{array}{l}621 . \\
477: \\
409: \\
305 .\end{array}$ \\
\hline $\begin{array}{l}a-11-013 L \\
R-11-014 L \\
R-11-015 L \\
B-11-0.16 L\end{array}$ & $\begin{array}{l}101.62 \\
107.60 \\
112.10 \\
121.87\end{array}$ & $\begin{array}{l}24.2 \\
26.4 \\
28.4 \\
33.5\end{array}$ & $\begin{array}{l}24.1 \\
26.8 \\
28.9 \\
34.0\end{array}$ & $\begin{array}{l}0.2545 \\
0.2535 \\
0.2566 \\
0.2620\end{array}$ & $\begin{array}{l}100.17 \\
105.70 \\
110.00 \\
119.60\end{array}$ & $\begin{array}{l}184.09 \\
182.41 \\
183.89 \\
186.01\end{array}$ & $\begin{array}{r}22.0 \\
7.6 \\
5.2 \\
3.0\end{array}$ & $\begin{array}{l}19.7 \\
6.6 \\
4.7 \\
2.7\end{array}$ & $\begin{array}{l}59671 . \\
21084 . \\
14597 . \\
6609 .\end{array}$ & $\begin{array}{l}78.63 \\
79.49 \\
79.65 \\
79.72\end{array}$ & $\begin{array}{l}60.11 \\
83.09 \\
84.85 \\
88.41\end{array}$ & $\begin{array}{l}1.25 \\
3.58 \\
5.19 \\
8.68\end{array}$ & $\begin{array}{l}22.15 \\
26.31 \\
29.85 \\
37.81\end{array}$ & $\begin{array}{l}13823 . \\
13595 \\
13628 \\
13611 .\end{array}$ & $\begin{array}{l}13676 \\
13578 \\
13472 \\
12993\end{array}$ & $\begin{array}{l}1.1 \\
0.1 \\
1.1 \\
4.5\end{array}$ & $\begin{array}{l}415 . \\
344 . \\
304: \\
239 .\end{array}$ \\
\hline $\begin{array}{l}\mathrm{B}-11-017 \mathrm{~L} \\
\mathrm{~B}-11-0.18 \mathrm{~L} \\
\mathrm{n}-11-019 \mathrm{~L} \\
\mathrm{R}-11-020 \mathrm{~L}\end{array}$ & $\begin{array}{l}100.42 \\
102.42 \\
104.03 \\
107.92\end{array}$ & $\begin{array}{l}23.6 \\
24.5 \\
25.2 \\
26.6\end{array}$ & $\begin{array}{l}23.6 \\
24.5 \\
25.2 \\
26.9\end{array}$ & $\begin{array}{l}0.1100 \\
0.1094 \\
0.1093 \\
0.1097\end{array}$ & $\begin{array}{r}97.65 \\
99.41 \\
100.82 \\
104.18\end{array}$ & $\begin{array}{l}79.77 \\
79.19 \\
79.05 \\
79.07\end{array}$ & $\begin{array}{r}22.2 \\
7.6 \\
5.2 \\
3.0\end{array}$ & $\begin{array}{r}19.9 \\
6.8 \\
4.7 \\
.2 .7\end{array}$ & $\begin{array}{l}70971 . \\
24322 . \\
16691 . \\
9701 .\end{array}$ & $\begin{array}{l}93.16 \\
92.75 \\
92.64 \\
92.54\end{array}$ & $\begin{array}{l}93.74 \\
94.34 \\
94.96 \\
96.39\end{array}$ & $\begin{array}{l}0.54 \\
1.59 \\
2.32 \\
3.86\end{array}$ & $\begin{array}{r}6.97 \\
8.88 \\
10.23 \\
13.45\end{array}$ & $\begin{array}{l}5999 . \\
5940 . \\
5918 . \\
5891 .\end{array}$ & $\begin{array}{l}6026 . \\
6027 . \\
6006 \\
5775\end{array}$ & $\begin{array}{r}-0.5 \\
-1.5 \\
-1.5 \\
2.0\end{array}$ & $\begin{array}{l}572 . \\
445 . \\
385 . \\
291 .\end{array}$ \\
\hline $\begin{array}{l}\mathrm{R}-11-021 \mathrm{~L} \\
\mathrm{a}-11-022 \mathrm{~L} \\
\mathrm{~B}-11-023 \mathrm{~L} \\
\mathrm{R}-11-024 \mathrm{~L}\end{array}$ & $\begin{array}{r}94.89 \\
100.15 \\
103.63 \\
112.44\end{array}$ & $\begin{array}{l}21.4 \\
23.6 \\
25.1 \\
28.7\end{array}$ & $\begin{array}{l}21.4 \\
23.5 \\
25.0 \\
29.1\end{array}$ & $\begin{array}{l}0.2134 \\
0.2120 \\
0.2125 \\
0.2135\end{array}$ & $\begin{array}{r}93.77 \\
98.62 \\
101.82 \\
109.92\end{array}$ & $\begin{array}{l}155.29 \\
153.59 \\
153.47 \\
153.03\end{array}$ & $\begin{array}{r}22.0 \\
7.6 \\
5.2 \\
3.0\end{array}$ & $\begin{array}{r}19.7 \\
6.8 \\
4.7 \\
2.7\end{array}$ & $\begin{array}{c}58522 . \\
20633 . \\
14258 \\
8396\end{array}$ & $\begin{array}{l}77.38 \\
78.03 \\
78.18 \\
78.29\end{array}$ & $\begin{array}{l}78.17 \\
81.06 \\
82.51 \\
85.72\end{array}$ & $\begin{array}{l}1.05 \\
3.01 \\
4.33 \\
7.42\end{array}$ & $\begin{array}{l}16.97 \\
20.61 \\
23.29 \\
30.44\end{array}$ & $\begin{array}{l}11757 . \\
11554 . \\
11495 . \\
11336 .\end{array}$ & $\begin{array}{l}11481 . \\
11420 \\
11228 \\
11108\end{array}$ & $\begin{array}{l}2.4 \\
1.2 \\
2.3 \\
2.0\end{array}$ & $\begin{array}{l}461 . \\
373 . \\
328 . \\
248 .\end{array}$ \\
\hline $\begin{array}{l}R-11-025 L \\
R-11-026 L \\
R-11-027 L \\
R-11-028 L\end{array}$ & $\begin{array}{r}98.06 \\
101.39 \\
103.96 \\
109.39\end{array}$ & $\begin{array}{l}22.7 \\
24.1 \\
25.1 \\
27.2\end{array}$ & $\begin{array}{l}22.7 \\
24.0 \\
25.1 \\
27.6\end{array}$ & $\begin{array}{l}0.1544 \\
0.1528 \\
0.1538 \\
0.1544\end{array}$ & $\begin{array}{r}96.25 \\
99.41 \\
101.70 \\
106.75\end{array}$ & $\begin{array}{l}112.13 \\
110.61 \\
111.07 \\
111.02\end{array}$ & $\begin{array}{r}22.0 \\
7.6 \\
5.2 \\
3.0\end{array}$ & $\begin{array}{r}19.7 \\
6.8 \\
4.7 \\
2.7\end{array}$ & $\begin{array}{r}65538 . \\
22812 . \\
15708 . \\
9144 .\end{array}$ & $\begin{array}{l}86.94 \\
86.87 \\
86.91 \\
86.59\end{array}$ & $\begin{array}{l}87.72 \\
89.08 \\
90.12 \\
91.98\end{array}$ & $\begin{array}{l}0.75 \\
2.21 \\
3.21 \\
5.39\end{array}$ & $\begin{array}{l}10.73 \\
13.42 \\
15.45 \\
20.11\end{array}$ & $\begin{array}{l}8457 . \\
8300 . \\
8316 . \\
8256 .\end{array}$ & $\begin{array}{l}8208 . \\
8362 . \\
8317 . \\
8051 .\end{array}$ & $\begin{array}{r}3.0 \\
-0.7 \\
-0.0 \\
2.5\end{array}$ & $\begin{array}{l}521 \% . \\
412 . \\
358 . \\
273 .\end{array}$ \\
\hline $\begin{array}{l}R-11-029 L * \\
R-11-030 L * \\
R-11-03 L L \\
R-11-032 L\end{array}$ & $\begin{array}{r}99.73 \\
100.79 \\
101.62 \\
103.61\end{array}$ & $\begin{array}{l}23.4 \\
23.8 \\
24.2 \\
25.1\end{array}$ & $\begin{array}{l}23.3 \\
23.8 \\
24.1 \\
25.1\end{array}$ & $\begin{array}{l}0.0655 \\
0.0644 \\
0.0644 \\
0.0648\end{array}$ & $\begin{array}{l}95.45 \\
96.22 \\
96.72 \\
98.67\end{array}$ & $\begin{array}{l}47.58 \\
46.77 \\
46.75 \\
46.97\end{array}$ & $\begin{array}{r}22.2 \\
7.6 \\
5.2 \\
3.0\end{array}$ & $\begin{array}{l}19.9 \\
6.8 \\
4.7 \\
2.7\end{array}$ & $\begin{array}{c}73043 . \\
24989 . \\
17116 . \\
9896 .\end{array}$ & $\begin{array}{l}96.00 \\
95.63 \\
95.52 \\
95.25\end{array}$ & $\begin{array}{l}96.34 \\
96.58 \\
96.88 \\
97.54\end{array}$ & $\begin{array}{l}0.30 \\
0.94 \\
1.35 \\
2.31\end{array}$ & $\begin{array}{l}3.56 \\
4.68 \\
5.42 \\
7.41\end{array}$ & $\begin{array}{l}3581 . \\
3516 . \\
3510 . \\
3518 .\end{array}$ & $\begin{array}{l}3312 . \\
3572 . \\
3501 . \\
3442 .\end{array}$ & $\begin{array}{r}7.5 \\
-1.6 \\
0.3 \\
2.2\end{array}$ & $\begin{array}{l}668 . \\
499 . \\
431 . \\
316 .\end{array}$ \\
\hline $\begin{array}{l}\mathrm{R}-11-033 \mathrm{~L} \\
\mathrm{R}-11-034 \mathrm{~L} \\
\mathrm{R}-11-035 \mathrm{~L} \\
\mathrm{R}-11-036 \mathrm{~L}\end{array}$ & $\begin{array}{r}96.73 \\
100.99 \\
104.21 \\
111.15\end{array}$ & $\begin{array}{l}22.2 \\
23.9 \\
25.4 \\
28.1\end{array}$ & $\begin{array}{l}22.1 \\
23.9 \\
25.2 \\
28.4\end{array}$ & $\begin{array}{l}0.1841 \\
0.1822 \\
0.1844 \\
0.1840\end{array}$ & $\begin{array}{r}95.25 \\
98.99 \\
101.95 \\
108.50\end{array}$ & $\begin{array}{l}133.77 \\
131.99 \\
133.16 \\
132.05\end{array}$ & $\begin{array}{r}22.0 \\
7.6 \\
5.2 \\
3.0\end{array}$ & $\begin{array}{l}19.7 \\
6.8 \\
4.7 \\
2.7\end{array}$ & $\begin{array}{r}62408 \\
21831 \\
15058 \\
8627\end{array}$ & $\begin{array}{l}62.64 \\
62.81 \\
62.68 \\
83.07\end{array}$ & $\begin{array}{l}83.58 \\
85.47 \\
86.74 \\
89.50\end{array}$ & $\begin{array}{l}0.91 \\
2.66 \\
3.86 \\
6.43\end{array}$ & $\begin{array}{l}13.62 \\
16.85 \\
19.40 \\
24.87\end{array}$ & $\begin{array}{l}10106 . \\
9919 . \\
9967 . \\
9798 .\end{array}$ & $\begin{array}{c}9977 . \\
10089 . \\
10024 . \\
9608\end{array}$ & $\begin{array}{r}1.3 \\
-1.7 \\
-0.6 \\
1.9\end{array}$ & $\begin{array}{l}391 . \\
342 . \\
262 .\end{array}$ \\
\hline
\end{tabular}




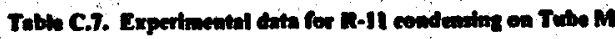

\begin{tabular}{|c|c|c|c|c|c|c|c|c|c|c|c|c|c|c|c|c|c|}
\hline Rum Na. & Pम & (psia) & (min) & $F_{e}$ & $\Gamma_{c}^{T_{c}}$ & $(m, m)$ & $\left(\mathbf{F}_{\mathbf{w}}\right.$ & $(m / 0)$ & Re & Tyin & Trom & $\stackrel{\Delta T_{w}}{F_{T}}$ & $\stackrel{\Delta T}{P}$ & $Q_{e}$ & $\left(Q_{n}\right)$ & ( & $\underset{(m p o f}{v}$ \\
\hline 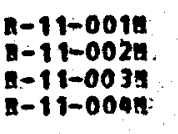 & $\begin{array}{l}101.01 \\
102.02 \\
102.94 \\
104.99\end{array}$ & $\begin{array}{l}23.9 \\
24.9 \\
24.7 \\
25.5\end{array}$ & $\begin{array}{l}23.9 \\
24.9 \\
24.7 \\
25.6\end{array}$ & $\begin{array}{l}0.0814 \\
0.0814 \\
0.0814 \\
0.0828 .\end{array}$ & $\begin{array}{r}97.29 \\
97.96 \\
98.77 \\
100.70\end{array}$ & $\begin{array}{l}59.07 \\
59.03 \\
58.99 \\
59.88\end{array}$ & $\begin{array}{r}28.0 \\
7.6 \\
5.2 \\
3.0\end{array}$ & $\begin{array}{r}14.9 \\
5.4 \\
3.7 \\
2.1\end{array}$ & $\begin{array}{c}5135 . \\
1865 . \\
1283 . \\
750 .\end{array}$ & $\begin{array}{l}75.06 \\
74.97 \\
75.17 \\
75.26\end{array}$ & $\begin{array}{l}75.52 \\
76.16 \\
76.85 \\
78.79\end{array}$ & $\begin{array}{l}0.43 \\
1.17 \\
1.67 \\
2.87\end{array}$ & $\begin{array}{l}25.72 \\
26.45 \\
26.93 \\
27.97\end{array}$ & $\begin{array}{l}4439 . \\
4431 \% \\
4422 . \\
4476 .\end{array}$ & $\begin{array}{l}4463 . \\
4451 . \\
4327 \\
4300 .\end{array}$ & $\begin{array}{r}-0.5 \\
-0.5 \\
2.1 \\
. .0\end{array}$ & $\begin{array}{l}164 . \\
.159 . \\
156 . \\
152 .\end{array}$ \\
\hline $\begin{array}{l}R-11-005 n \\
n-11-006 n \\
2-11-007 n \\
n-11-006 n\end{array}$ & $\begin{array}{l}103.55 \\
105.42 \\
106.49 \\
109.37\end{array}$ & $\begin{array}{l}24.7 \\
25.4 \\
25.9 \\
27.2\end{array}$ & $\begin{array}{l}25.0 \\
25.8 \\
26.3 \\
27.6\end{array}$ & $\begin{array}{l}0.1310 \\
0.1303 \\
0.1303 \\
0.1296\end{array}$ & $\begin{array}{l}100.64 \\
102.12 \\
102.93 \\
105.47\end{array}$ & $\begin{array}{l}94.71 \\
94.12 \\
94.05 \\
93.31\end{array}$ & $\begin{array}{r}21.0 \\
7.6 \\
5.2 \\
3.0\end{array}$ & $\begin{array}{r}14.9 \\
5.4 \\
3.7 \\
2.1\end{array}$ & $\begin{array}{r}1283 . \\
1565 \\
1075 \\
629\end{array}$ & $\begin{array}{l}61.51 \\
61.62 \\
61.51 \\
61.56\end{array}$ & $\begin{array}{l}62.24 \\
63.45 \\
64.14 \\
66.13\end{array}$ & $\begin{array}{l}0.73 \\
1.83 \\
2.63 \\
4.57\end{array}$ & $\begin{array}{r}41.67 \\
42.89 \\
43.66 \\
45.52\end{array}$ & $\begin{array}{l}7094 . \\
7034 . \\
7020 . \\
6939 .\end{array}$ & $\begin{array}{l}7492 . \\
6935 . \\
6821 . \\
6846 .\end{array}$ & $\begin{array}{r}-5.6 \\
1.4 \\
2.8 \\
1.3\end{array}$ & $\begin{array}{l}161 . \\
155 . \\
152 . \\
144 .\end{array}$ \\
\hline $\begin{array}{l}2-11-0094 \\
8-11-0104 \\
2-11-0114 \\
8-11-0124\end{array}$ & $\begin{array}{l}105.69 \\
106.14 \\
107.27 \\
108.75\end{array}$ & $\begin{array}{l}26.0 \\
26.2 \\
26.7 \\
27.4\end{array}$ & $\begin{array}{l}26.0 \\
26.1 \\
26.8 \\
27.3\end{array}$ & $\begin{array}{l}0.0437 \\
0.0435 \\
0.0435 \\
0.0438\end{array}$ & $\begin{array}{r}98.11 \\
98.56 \\
99.95 \\
101.55\end{array}$ & $\begin{array}{l}31.66 \\
31.49 \\
31.45 \\
31.67\end{array}$ & $\begin{array}{r}21.3 \\
7.6 \\
5.2 \\
3.0\end{array}$ & $\begin{array}{r}15.1 \\
5.4 \\
3.7 \\
2.1\end{array}$ & $\begin{array}{l}6515 . \\
2323 . \\
1605 \\
935 .\end{array}$ & $\begin{array}{l}93.67 \\
93.62 \\
94.36 \\
94.89\end{array}$ & $\begin{array}{l}94.14 \\
94.29 \\
95.31 \\
96.43\end{array}$ & $\begin{array}{l}0.24 \\
0.66 \\
0.95 \\
1.54\end{array}$ & $\begin{array}{l}11.83 \\
12.18 \\
12.44 \\
13.09\end{array}$ & $\begin{array}{l}2365 . \\
2351 . \\
2345 \\
2357\end{array}$ & $\begin{array}{l}2536 . \\
2506 \\
2455 \\
2295\end{array}$ & $\begin{array}{r}-7.2 \\
-6.6 \\
-4.7 \\
2.6\end{array}$ & $\begin{array}{l}189 . \\
183 . \\
179 . \\
171 .\end{array}$ \\
\hline $\begin{array}{l}n-11-013 n \\
n-11-014 n \\
n-11-015 n \\
n-11-016 n\end{array}$ & $\begin{array}{l}105.98 \\
106.96 \\
107.60 \\
109.12\end{array}$ & $\begin{array}{l}26.0 \\
26.4 \\
26.9 \\
27.5\end{array}$ & $\begin{array}{l}26.0 \\
26.5 \\
26.9 \\
27.5\end{array}$ & $\begin{array}{l}0.0434 \\
0.0437 \\
0.0437 \\
0.0437\end{array}$ & $\begin{array}{r}98.52 \\
99.81 \\
100.68 \\
102.35\end{array}$ & $\begin{array}{l}31.48 \\
31.60 \\
31.57 \\
31.52\end{array}$ & $\begin{array}{r}21.3 \\
7.6 \\
5.2 \\
3.0\end{array}$ & $\begin{array}{r}15.1 \\
5.4 \\
3.7 \\
2.1\end{array}$ & $\begin{array}{l}6514 . \\
2338 . \\
1610 . \\
938 .\end{array}$ & $\begin{array}{l}93.65 \\
94.16 \\
94.62 \\
95.18\end{array}$ & $\begin{array}{l}94.13 \\
94.84 \\
95.58 \\
96.73\end{array}$ & $\begin{array}{l}0.25 \\
0.67 \\
0.95 \\
1.55\end{array}$ & $\begin{array}{l}11.99 \\
12.46 \\
12.69 \\
13.16\end{array}$ & $\begin{array}{l}2351 . \\
2357 . \\
2352 . \\
2345 .\end{array}$ & $\begin{array}{l}2525 . \\
2548 . \\
2474 . \\
2312 .\end{array}$ & $\begin{array}{r}-7.4 \\
-8.1 \\
-5.2 \\
1.4\end{array}$ & $\begin{array}{l}186 . \\
179 . \\
176 . \\
169 .\end{array}$ \\
\hline $\begin{array}{l}8-11-017 \mathrm{~A} \\
8-11-0184 \\
8-11-0194 \\
0-11-020 \mathrm{~s} .\end{array}$ & $\begin{array}{l}103.74 \\
103.92 \\
104.12 \\
105.08\end{array}$ & $\begin{array}{l}24.9 \\
25.0 \\
25.2 \\
25.5\end{array}$ & $\begin{array}{l}25.0 \\
25.1 \\
25.2 \\
25.6\end{array}$ & $\begin{array}{l}0.0658 \\
0.0656 \\
0.0647 \\
0.0647\end{array}$ & $\begin{array}{l}98.93 \\
98.89 \\
98.91 \\
99.55\end{array}$ & $\begin{array}{l}47.66 \\
47.50 \\
46.88 \\
46.86\end{array}$ & $\begin{array}{r}21.0 \\
7.6 \\
5.2 \\
3.0\end{array}$ & $\begin{array}{r}14.9 \\
5.4 \\
3.7 \\
2.1\end{array}$ & $\begin{array}{l}5684 . \\
2049 . \\
1401 . \\
810 .\end{array}$ & $\begin{array}{l}83.20 \\
82.61 \\
82.31 \\
82.10\end{array}$ & $\begin{array}{l}83.59 \\
83.58 \\
83.70 \\
84.38\end{array}$ & $\begin{array}{l}0.35 \\
0.95 \\
1.38 \\
2.28\end{array}$ & $\begin{array}{l}20.35 \\
20.82 \\
21.11 \\
21.84\end{array}$ & $\begin{array}{l}3569 . \\
3557 \\
3510 . \\
3503 .\end{array}$ & $\begin{array}{l}3677 . \\
3606 . \\
3588 . \\
3414 .\end{array}$ & $\begin{array}{l}-3.0 \\
-1.4 \\
-2.2 \\
2.5\end{array}$ & $\begin{array}{l}166 . \\
162 . \\
158 . \\
152 .\end{array}$ \\
\hline $\begin{array}{l}8-11-021 n \\
n-11-0224 \\
8-11-023 n \\
8-11-024 n\end{array}$ & $\begin{array}{l}109.54 \\
112.26 \\
113.80 \\
116.97\end{array}$ & $\begin{array}{l}27.5 \\
28.7 \\
29.5 \\
31.2\end{array}$ & $\begin{array}{l}27.7 \\
29.0 \\
29.7 \\
31.3\end{array}$ & $\begin{array}{l}0.1557 \\
0.1559 \\
0.1565 \\
0.1568\end{array}$ & $\begin{array}{l}106.35 \\
108.72 \\
110.28 \\
112.93\end{array}$ & $\begin{array}{l}111.99 \\
111.84 \\
112.12 \\
112.08\end{array}$ & $\begin{array}{r}20.7 \\
7.6 \\
5.2 \\
3.0\end{array}$ & $\begin{array}{r}14.7 \\
5.4 \\
3.7 \\
2.1\end{array}$ & $\begin{array}{l}4165 . \\
1552 . \\
1068 \\
626\end{array}$ & $\begin{array}{l}60.53 \\
60.08 \\
60.82 \\
60.82\end{array}$ & $\begin{array}{l}61.35 \\
63.03 \\
63.93 \\
66.10\end{array}$ & $\begin{array}{l}0.80 \\
2.15 \\
3.11 \\
5.28\end{array}$ & $\begin{array}{l}48.60 \\
50.30 \\
51.43 \\
53.51\end{array}$ & $\begin{array}{l}6326 . \\
6287 \\
8291 . \\
8254 .\end{array}$ & $\begin{array}{l}8327 . \\
8150 . \\
809 . \\
7915 .\end{array}$ & $\begin{array}{r}-0.0 \\
1.7 \\
2.1 \\
1.1\end{array}$ & $\begin{array}{l}162 . \\
156 . \\
153 . \\
146 .\end{array}$ \\
\hline $\begin{array}{l}\mathrm{R}-11-025 \mathrm{n} \\
\mathrm{B}-11-026 \mathrm{n} \\
\mathrm{a}-11-027 \mathrm{~A} \\
\mathrm{~B}-11-028 \mathrm{n}\end{array}$ & $\begin{array}{l}102.04 \\
103.59 \\
104.54 \\
106.63\end{array}$ & $\begin{array}{l}24.2 \\
24.9 \\
25.9 \\
26.4\end{array}$ & $\begin{array}{l}24.3 \\
25.0 \\
25.4 \\
26.3\end{array}$ & $\begin{array}{l}0.0986 \\
0.0986 \\
0.0994 \\
0.0986\end{array}$ & $\begin{array}{r}98.38 \\
99.65 \\
100.37 \\
102.50\end{array}$ & $\begin{array}{l}71.44 \\
71.50 \\
71.91 \\
71.16\end{array}$ & $\begin{array}{r}21.0 \\
7.6 \\
5.2 \\
3.0\end{array}$ & $\begin{array}{r}14.9 \\
5.9 \\
3.7 \\
2.8\end{array}$ & $\begin{array}{l}4014 . \\
1758 . \\
1207 . \\
703 .\end{array}$ & $\begin{array}{l}70.00 \\
70.25 \\
70.18 \\
70.14\end{array}$ & $\begin{array}{l}70.56 \\
71.67 \\
72.23 \\
73.61\end{array}$ & $\begin{array}{l}0.53 \\
1.41 \\
2.04 \\
3.46\end{array}$ & $\begin{array}{l}31.76 \\
32.63 \\
33.34 \\
34.75\end{array}$ & $\begin{array}{l}5361 . \\
5356 . \\
5380 . \\
5310 .\end{array}$ & $\begin{array}{l}5551 . \\
5366 . \\
5293 . \\
5190 .\end{array}$ & $\begin{array}{r}-3.5 \\
-0.2 \\
1.6 \\
2.3\end{array}$ & $\begin{array}{l}160 . \\
156 . \\
153 . \\
145 .\end{array}$ \\
\hline $\begin{array}{l}\mathrm{B}-11-029 \mathrm{~B} \\
\mathrm{~A}-11-0305 \\
\mathrm{~B}-11-031 \mathrm{~B} \\
\mathrm{~B}-11-032 \mathrm{~B}\end{array}$ & $\begin{array}{l}101.68 \\
103.48 \\
104.70 \\
106.91\end{array}$ & $\begin{array}{l}24.2 \\
24.9 \\
25.4 \\
26.5\end{array}$ & $\begin{array}{l}24.2 \\
24.9 \\
25.5 \\
26.5\end{array}$ & $\begin{array}{l}0.1128 \\
0.1121 \\
0.1136 \\
0.1139\end{array}$ & $\begin{array}{r}98.48 \\
99.45 \\
100.25 \\
102.25\end{array}$ & $\begin{array}{l}81.23 \\
61.16 \\
62.16 \\
82.27\end{array}$ & $\begin{array}{r}21.0 \\
7.6 \\
5.2 \\
3.0\end{array}$ & $\begin{array}{r}14.9 \\
5.9 \\
3.7 \\
2.1\end{array}$ & $\begin{array}{c}4540 . \\
1657 . \\
1136 . \\
663 .\end{array}$ & $\begin{array}{l}65.68 \\
65.80 \\
65.72 \\
65.59\end{array}$ & $\begin{array}{l}66.31 \\
67.41 \\
68.06 \\
69.49\end{array}$ & $\begin{array}{l}0.61 \\
1.61 \\
2.34 \\
3.89\end{array}$ & $\begin{array}{l}35.69 \\
36.67 \\
37.81 \\
39.37\end{array}$ & $\begin{array}{l}6099 . \\
6080 . \\
6146 . \\
6137 .\end{array}$ & $\begin{array}{l}6401 . \\
6126 . \\
6080 . \\
5833 .\end{array}$ & $\begin{array}{r}-9.9 \\
-0.7 \\
1.1 \\
5.0\end{array}$ & $\begin{array}{l}162 . \\
156 . \\
154 . \\
148 .\end{array}$ \\
\hline
\end{tabular}


Table C.8. Experimental data for R-1l condenalng on Tube N

\begin{tabular}{|c|c|c|c|c|c|c|c|c|c|c|c|c|c|c|c|c|}
\hline $\mathbf{R}$ & $\mathbf{T}_{\mathbf{v}}$ & $\underset{\text { (psia) }}{\mathbf{P}}$ & $P_{\text {sal }}$ & $\underset{(\mathrm{EPm})}{\mathbf{F}_{\mathrm{c}}}$ & $\begin{array}{c}T_{c} \\
(\text { P } \\
(\text { F) }\end{array}$ & $\left(i b-m_{m} / h\right)$ & $\underset{(\mathrm{spm})}{F_{\mathbf{w}}}$ & 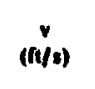 & $\mathrm{Re}$ & $T_{w, j, i n}$ & $T_{\text {woul }}$ & $\begin{array}{l}T_{w w} \\
\text { f) }\end{array}$ & $\begin{array}{c}\Delta T \\
(\mathbf{P} F)\end{array}$ & $\begin{array}{c}Q_{c} \\
(B: u / h)\end{array}$ & $\underset{(B u w / h)}{Q_{w}}$ & 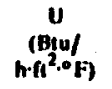 \\
\hline $\begin{array}{r}-11-0014 \\
-11-0024 \\
-11-0034 \\
-11-004 n\end{array}$ & $\begin{array}{l}10.40 \\
0.87 \\
11.22 \\
2.06\end{array}$ & $\begin{array}{l}23.4 \\
23.5 \\
23.7 \\
24.0\end{array}$ & $\begin{array}{l}23.8 \\
24.0 \\
24.3\end{array}$ & $\begin{array}{l}0.0424 \\
0.0424 \\
0.0424 \\
0.0424\end{array}$ & $\begin{array}{l}92.84 \\
93.13 \\
93.39 \\
93.93\end{array}$ & $\begin{array}{l}30.92 \\
30.91 \\
30.91 \\
30.89\end{array}$ & $\begin{array}{r}19.0 \\
7.6 \\
5.2 \\
3.0\end{array}$ & $\begin{array}{r}16.9 \\
6.7 \\
4.6 \\
2.7\end{array}$ & $\begin{array}{c}57172 . \\
22933 . \\
15723 . \\
9109 .\end{array}$ & $\begin{array}{l}88.22 \\
68.28 \\
88.33 \\
88.34\end{array}$ & $\begin{array}{l}88.53 \\
88.95 \\
89.25 \\
89.95\end{array}$ & $\begin{array}{l}0.27 \\
0.66 \\
0.91 \\
1.59\end{array}$ & $\begin{array}{l}12.02 \\
12.25 \\
12.43 \\
12.92\end{array}$ & . & $\begin{array}{l}\text { 7. }-8 \\
\text { 7. }-7 \\
\text { 7. }-1 \\
\text { 7. }-2\end{array}$ & $\begin{array}{l}179 . \\
177 . \\
170 .\end{array}$ \\
\hline $\begin{array}{l}8-11-005: \\
8-11-0064 \\
8-11-0074 \\
8-11-0088\end{array}$ & $\begin{array}{l}0.73 \\
1.08 \\
1.51 \\
2.44\end{array}$ & $\begin{array}{l}23.5 \\
23.7 \\
23.9 \\
24.2\end{array}$ & $\begin{array}{l}3.9 \\
4.1 \\
4.5\end{array}$ & $\begin{array}{l}0.0425 \\
0.0423 \\
0.0423 \\
0.0425\end{array}$ & $\begin{array}{l}93.20 \\
93.42 \\
93.81 \\
94.46\end{array}$ & $\begin{array}{l}30.98 \\
30.83 \\
30.81 \\
30.95\end{array}$ & $\begin{array}{r}19.0 \\
7.6 \\
5.2 \\
3.0\end{array}$ & $\begin{array}{r}16.9 \\
6.7 \\
4.6 \\
2.7\end{array}$ & $\begin{array}{r}57259 . \\
22939 . \\
15733 . \\
9119 .\end{array}$ & $\begin{array}{l}68.34 \\
88.30 \\
88.37 \\
88.43\end{array}$ & $\begin{array}{l}7 \\
8 \\
1 \\
6\end{array}$ & $\begin{array}{l}0.28 \\
0.67 \\
0.93 \\
1.61\end{array}$ & $\begin{array}{l}12.22 \\
12.44 \\
12.67 \\
13.20\end{array}$ & & $\begin{array}{l}2678 .-15 \\
2548 .-10 \\
2398 .-3 \\
2407 .-3\end{array}$ & 166 \\
\hline $\begin{array}{l}R-11-009 \\
R-11-0104 \\
R-11-011 R \\
R-11-012 \%\end{array}$ & $\begin{array}{l}100.30 \\
101.81 \\
02.89 \\
04.47\end{array}$ & $\begin{array}{l}23.2 \\
23.9 \\
24.4 \\
25.2\end{array}$ & $\begin{array}{l}23.6 \\
24.2 \\
24.7 \\
25.4\end{array}$ & $\begin{array}{l}0.0975 \\
0.0983 \\
0.0985 \\
0.0985\end{array}$ & $\begin{array}{r}96.59 \\
98.03 \\
99.05 \\
100.35\end{array}$ & $\begin{array}{l}70.79 \\
71.28 \\
71.36 \\
71.27\end{array}$ & $\begin{array}{r}18.6 \\
7.6 \\
5.1 \\
3.0\end{array}$ & $\begin{array}{r}16.5 \\
6.7 \\
4.5 \\
2.7\end{array}$ & $\begin{array}{r}43941 . \\
18094 . \\
12205 . \\
7244 .\end{array}$ & $\begin{array}{l}68.61 \\
68.78 \\
68.83 \\
68.83\end{array}$ & $\begin{array}{l}69.24 \\
70.21 \\
70.93 \\
72.26\end{array}$ & $\begin{array}{l}0.60 \\
1.42 \\
2.09 \\
3.42\end{array}$ & $\begin{array}{l}31.37 \\
32.31 \\
33.01 \\
33.93\end{array}$ & $\begin{array}{l}5324 . \\
5351 . \\
5350 . \\
5333 .\end{array}$ & $\begin{array}{rr}5539 . & -4.0 \\
5389 . & -0.7 \\
5321 . & 0.5 \\
5124 . & 3.9\end{array}$ & 145 \\
\hline $\begin{array}{l}8-11-0.0134 \\
8-11-0144 \\
8-11-0154 \\
B-11-0164\end{array}$ & $\begin{array}{l}108.60 \\
111.25 \\
112.42 \\
115.26\end{array}$ & $\begin{array}{l}26.9 \\
28.2 \\
28.7\end{array}$ & $\begin{array}{l}27.2 \\
26.5 \\
29.1 \\
30.5\end{array}$ & $\begin{array}{l}0.1553 \\
0.1554 \\
0.1560 \\
0.1562\end{array}$ & $\begin{array}{l}105.36 \\
107.94 \\
108.97 \\
111.50\end{array}$ & $\begin{array}{l}111.77 \\
111.60 \\
111.93 \\
111.80\end{array}$ & $\begin{array}{r}18.4 \\
7.4 \\
5.2 \\
3.0\end{array}$ & $\begin{array}{l}16.3 \\
6.6 \\
4.6 \\
2.7\end{array}$ & $\begin{array}{r}30058 \\
15527 . \\
10972 \\
6437\end{array}$ & $\begin{array}{l}59.05 \\
59.40 \\
59.34 \\
59.44\end{array}$ & $\begin{array}{l}60 . \\
61 . \\
62 .\end{array}$ & $\begin{array}{l}0.93 \\
2.20 \\
3.10 \\
5.22\end{array}$ & $\begin{array}{l}49.07 \\
50.75 \\
51.52 \\
53.21\end{array}$ & $\begin{array}{l}8320 . \\
8279 . \\
8291 . \\
8252 .\end{array}$ & $\begin{array}{rr}8532 . & -2.6 \\
6135 . & 1.7 \\
8060 . & 2.8 \\
7833 . & 5.1\end{array}$ & $\begin{array}{l}152 \\
147\end{array}$ \\
\hline $\begin{array}{l}8-11-017 n \\
8-11-0184 \\
8-11-0198 \\
8-11-0204\end{array}$ & $\begin{array}{r}99.79 \\
100.24 \\
100.97 \\
102.06\end{array}$ & $\begin{array}{l}23.2 \\
23.4 \\
23.7 \\
24.2\end{array}$ & $\begin{array}{l}23.4 \\
23.6 \\
23.9 \\
24.3\end{array}$ & $\begin{array}{l}0.0617 \\
0.0610 \\
0.0617 \\
0.0617\end{array}$ & $\begin{array}{l}95.56 \\
95.61 \\
96.18 \\
97.15\end{array}$ & $\begin{array}{l}44.62 \\
44.34 \\
44.79 \\
44.75\end{array}$ & $\begin{array}{r}18.8 \\
6.8 \\
5.2 \\
3.0\end{array}$ & $\begin{array}{r}16.7 \\
6.0 \\
4.6 \\
2.7\end{array}$ & $\begin{array}{r}51759 . \\
18762 . \\
14395 \\
8347 .\end{array}$ & $\begin{array}{l}80.65 \\
80.57 \\
80.63 \\
80.59\end{array}$ & $\begin{array}{l}81 \\
81 . \\
81\end{array}$ & $\begin{array}{l}0.38 \\
0.90 \\
1.32 \\
2.21\end{array}$ & $\begin{array}{l}18.94 \\
19.21 \\
19.68\end{array}$ & & $\begin{array}{rr}3545 . & -5 \\
3070 . & 7 \\
3417 . & -1 \\
3315 . & 1\end{array}$ & 15 \\
\hline $\begin{array}{l}B-11-021 B \\
Q-11-022 B \\
B-11-023 B \\
B-11-024 B\end{array}$ & $\begin{array}{l}102.66 \\
104.52 \\
105.79 \\
108.38\end{array}$ & $\begin{array}{l}24.4 \\
25.2 \\
25.7 \\
26.9\end{array}$ & $\begin{array}{l}24.6 \\
25.4 \\
26.0 \\
27.1\end{array}$ & $\begin{array}{l}0.1343 \\
0.1350 \\
0.1350 \\
0.1350\end{array}$ & $\begin{array}{r}99.79 \\
101.24 \\
102.42 \\
104.83\end{array}$ & $\begin{array}{l}97.16 \\
97.56 \\
97.45 \\
97.22\end{array}$ & $\begin{array}{r}18.6 \\
7.6 \\
5.2 \\
3.6\end{array}$ & $\begin{array}{r}16.5 \\
6.7 \\
4.6 \\
2.7\end{array}$ & $\begin{array}{r}38076 \\
15749 \\
10857 \\
6362\end{array}$ & $\begin{array}{l}58.51 \\
58.70 \\
58.80 \\
58.92\end{array}$ & $\begin{array}{l}59.35 \\
60.60 \\
61.54 \\
63.55\end{array}$ & $\begin{array}{l}0.63 \\
1.90 \\
2.74 \\
4.63\end{array}$ & $\begin{array}{l}43.72 \\
44.87 \\
45.62 \\
47.14\end{array}$ & & $\begin{array}{lr}7683 . & -5.4 \\
7204 . & 1.3 \\
7122 . & 2.2 \\
6945 . & 4.1\end{array}$ & $\begin{array}{l}15 \\
15 \\
15 \\
14\end{array}$ \\
\hline 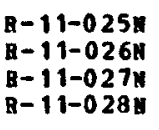 & $\begin{array}{l}100.19 \\
100.91 \\
101.81\end{array}$ & $\begin{array}{l}23.5 \\
21.6 \\
24.2 \\
24.9\end{array}$ & $\begin{array}{l}23.5 \\
23.8 \\
24.2 \\
24.9\end{array}$ & $\begin{array}{l}0.0788 \\
0.0786 \\
0.0788 \\
0.0792\end{array}$ & $\begin{array}{l}95.54 \\
95.83 \\
96.65 \\
97.94\end{array}$ & $\begin{array}{l}57.24 \\
57.07 \\
57.18 \\
57.40\end{array}$ & $\begin{array}{r}18.6 \\
7.6 \\
5.2 \\
3.0\end{array}$ & $\begin{array}{r}16.5 \\
6.7 \\
4.6 \\
2.7\end{array}$ & $\begin{array}{l}4790 \\
196 \\
134 \\
78\end{array}$ & $\begin{array}{l}75.31 \\
75.22 \\
75.36 \\
75.40\end{array}$ & $\begin{array}{l}75.83 \\
76.38 \\
77.01 \\
78.18\end{array}$ & $\begin{array}{l}0.48 \\
1.14 \\
1.64 \\
2.75\end{array}$ & $\begin{array}{l}25.11 \\
25.62 \\
26.56\end{array}$ & $\begin{array}{l}43 \\
42 \\
42 \\
43\end{array}$ & $\begin{array}{rr}4417 . & -2.6 \\
4311 . & -0.5 \\
4260 . & 0.8 \\
4119 . & 4.2\end{array}$ & $\begin{array}{l}15 \\
15\end{array}$ \\
\hline $\begin{array}{l}B-11-029 K \\
B-11-0304 \\
R-11-031 A \\
B-11-032 A\end{array}$ & $\begin{array}{l}101.45 \\
102.79 \\
103.68 \\
105.49\end{array}$ & $\begin{array}{l}23.7 \\
24.2 \\
24.7 \\
25.7\end{array}$ & $\begin{array}{l}24.1 \\
24.6 \\
25.0 \\
25.8\end{array}$ & $\begin{array}{l}0.1157 \\
0.1153 \\
0.1155 \\
0.1157\end{array}$ & $\begin{array}{r}98.13 \\
99.07 \\
99.81 \\
101.28\end{array}$ & $\begin{array}{l}83.90 \\
83.52 \\
83.61 \\
83.65\end{array}$ & $\begin{array}{l}18.4 \\
7.6 \\
5.2 \\
3.0\end{array}$ & $\begin{array}{r}16.3 \\
6.7 \\
4.6 \\
2.7\end{array}$ & $\begin{array}{c}40496 . \\
16873 . \\
11568 \\
6741 .\end{array}$ & $\begin{array}{l}63.45 \\
63.63 \\
63.40 \\
63.31\end{array}$ & $\begin{array}{l}64.20 \\
65.26 \\
65.78 \\
67.29\end{array}$ & $\begin{array}{l}0.73 \\
1.63 \\
2.39 \\
3.98\end{array}$ & $\begin{array}{l}37.62 \\
38.34 \\
39.09 \\
40.20\end{array}$ & $\begin{array}{l}6301 . \\
6262 . \\
6263 . \\
6251 .\end{array}$ & $\begin{array}{rr}6750 . & -7.2 \\
6186 . & 1.2 \\
6200 . & 1.0 \\
5965 . & 4.6\end{array}$ & 142 \\
\hline
\end{tabular}


Table C.9. Experimentul data for R-11 condensing on Tube $\mathrm{O}$ (no rod on water atde)

\begin{tabular}{|c|c|c|c|c|c|c|c|c|c|c|c|c|c|c|c|c|c|}
\hline & $\underset{\text { (P) }}{\mathbf{T}_{\mathbf{v}}}$ & $\underset{\text { (pain) }}{p}$ & ia) & ce & $\frac{c}{f}$ & $g^{\prime}(n)$ & $w$ & (iiv) & Re & $\underset{\text { Trin }}{T_{\text {fin }}}$ & gut & $w$ & & (h) & (b) & (i) & $\begin{array}{l}u \\
(B+4) \\
\left.f^{2} \cdot \sigma_{F}\right)\end{array}$ \\
\hline 030 & 98.37 & $\begin{array}{l}22.2 \\
22.7 \\
23.5\end{array}$ & $\begin{array}{l}21.8 \\
22.4 \\
22.8 \\
23.4\end{array}$ & $\begin{array}{l}73 \\
76 \\
74 \\
62\end{array}$ & $\begin{array}{l}93.70 \\
95.05 \\
95.89 \\
96.93\end{array}$ & $\begin{array}{l}78.08 \\
78.25 \\
78.05 \\
77.09\end{array}$ & $\begin{array}{r}20.2 \\
7.6 \\
5.2 \\
3.0\end{array}$ & $\begin{array}{r}21.5 \\
8.1 \\
5.5 \\
3.2\end{array}$ & $\begin{array}{r}114 \\
43 \\
29 \\
17\end{array}$ & $\begin{array}{l}4 \\
0 \\
2\end{array}$ & & $\begin{array}{l}9 \\
9 \\
10 \\
0\end{array}$ & & & & $\begin{array}{l}-0 \\
-2 \\
-1 \\
1\end{array}$ & $\begin{array}{l}276 . \\
261 . \\
253 . \\
239 .\end{array}$ \\
\hline $\begin{array}{l}-11-0050 \\
-11-0060 \\
-11-0070 \\
-11-0080\end{array}$ & $\begin{array}{r}96.73 \\
99.45 \\
101.18 \\
104.14\end{array}$ & $\begin{array}{l}22.2 \\
23.2 \\
23.9 \\
25.2\end{array}$ & $\begin{array}{r}2.1 \\
3.2 \\
3.9 \\
5.2\end{array}$ & $\begin{array}{r}1582 \\
.1575 \\
.1586 \\
.1588\end{array}$ & $\begin{array}{r}95.00 \\
97.50 \\
99.01 \\
101.53\end{array}$ & $\begin{array}{l}114.99 \\
114.24 \\
114.85 \\
114.75\end{array}$ & $\begin{array}{r}20.2 \\
7.6 \\
5.2 \\
3.0\end{array}$ & $\begin{array}{r}21.5 \\
8.1 \\
5.5 \\
3.2\end{array}$ & $\begin{array}{l}76 . \\
29 . \\
89 .\end{array}$ & $\begin{array}{l}69 \\
49 \\
67 \\
69\end{array}$ & & $\begin{array}{l}6 \\
3 \\
5\end{array}$ & & & & 2.2 & $\begin{array}{l}265 . \\
251 . \\
244 . \\
230 .\end{array}$ \\
\hline $\begin{array}{l}-11-0090 \\
-11-0100 \\
-11-0110\end{array}$ & $\begin{array}{l}97.86 \\
98.29 \\
98.56 \\
99.50\end{array}$ & $\begin{array}{l}2.2 \\
2.4\end{array}$ & $\begin{array}{l}2.6 \\
2.8 \\
2.9 \\
3.3\end{array}$ & $\begin{array}{l}0.0593 \\
0.0597 \\
0.0591 \\
0.0599\end{array}$ & $\begin{array}{l}94.19 \\
94.87 \\
95.07 \\
95.90\end{array}$ & $\begin{array}{l}43.13 \\
43.42 \\
42.95\end{array}$ & $\begin{array}{r}20.2 \\
7.6 \\
5.2 \\
3.0\end{array}$ & $\begin{array}{r}21.5 \\
8.1 \\
5.5 \\
3.2\end{array}$ & $\begin{array}{r}131947 . \\
49471 . \\
33831 . \\
19612 .\end{array}$ & $\begin{array}{l}8.37 \\
7.81 \\
7.58 \\
7.55\end{array}$ & & $\begin{array}{l}0.32 \\
0.88 \\
1.24\end{array}$ & & & & $\begin{array}{r}2.0 \\
-1.5 \\
0.5 \\
3.1\end{array}$ & $\begin{array}{l}315 . \\
294 . \\
282 . \\
267 .\end{array}$ \\
\hline $\begin{array}{l}-11-0130 \\
-11-0140 \\
-11-0150 \\
-11-0160\end{array}$ & $\begin{array}{r}1.64 \\
3.88 \\
15.63\end{array}$ & $\begin{array}{r}24.9 \\
25.5\end{array}$ & $\begin{array}{l}4.1 \\
5.1 \\
5.9 \\
7.3\end{array}$ & $\begin{array}{l}0.1647 \\
0.1625 \\
0.1642 \\
0.1653\end{array}$ & & $\begin{array}{l}119.17 \\
117.37 \\
118.93 \\
118.90\end{array}$ & $\begin{array}{r}20.2 \\
7.6 \\
5.2\end{array}$ & $\begin{array}{r}21.5 \\
0.1 \\
5.5 \\
3.2\end{array}$ & $\begin{array}{l}106725 \\
40662 \\
28043 \\
16421\end{array}$ & $\begin{array}{l}70.83 \\
71.22 \\
71.29 \\
71.27\end{array}$ & & $\begin{array}{l}0.88 \\
2.27 \\
3.33\end{array}$ & & & & & $\begin{array}{l}266 . \\
251 . \\
244 . \\
230 .\end{array}$ \\
\hline $\begin{array}{l}-11-0170 \\
-11-0180 \\
-11-0190\end{array}$ & $\begin{array}{r}99.31 \\
99.67 \\
99.95\end{array}$ & $\begin{array}{l}22.7 \\
22.9 \\
23.0 \\
23.9\end{array}$ & $\begin{array}{l}23.2 \\
23.3 \\
23.4 \\
23.7\end{array}$ & $\begin{array}{l}0.0490 \\
0.0496 \\
0.0501 \\
0.0496\end{array}$ & $\begin{array}{l}95.57 \\
95.74 \\
96.20 \\
96.63\end{array}$ & $\begin{array}{l}35.60 \\
36.06 \\
36.36\end{array}$ & $\begin{array}{r}20.2 \\
7.6 \\
5.2 \\
3.6\end{array}$ & $\begin{array}{r}21.5 \\
6.1 \\
5.5 \\
3.2\end{array}$ & $\begin{array}{l}043 . \\
15 . \\
136 \\
324 .\end{array}$ & $\begin{array}{l}57 \\
21 \\
95 \\
32\end{array}$ & & $\begin{array}{l}0.28 \\
0.74 \\
1.05\end{array}$ & 7 & & & $\begin{array}{r}-4 \\
-3 \\
0 \\
1\end{array}$ & \\
\hline $\begin{array}{l}-11-0210 \\
-11-0220 \\
-11-0230\end{array}$ & $\begin{array}{r}96.69 \\
98.45 \\
99.57\end{array}$ & $\begin{array}{l}21.9 \\
22.5 \\
23.0 \\
23.7\end{array}$ & 8.8 & $\begin{array}{l}31 \\
33 \\
31 \\
30\end{array}$ & $\begin{array}{r}95.23 \\
96.66 \\
97.71\end{array}$ & $\begin{array}{l}89.51 \\
89.51\end{array}$ & $\begin{array}{r}20.2 \\
7.6 \\
5.2\end{array}$ & $\begin{array}{r}21.5 \\
8.1 \\
5.5 \\
3.2\end{array}$ & $\begin{array}{l}9449 . \\
1896 . \\
3656 .\end{array}$ & & & $\begin{array}{l}0.67 \\
1.79 \\
2.57 \\
4.34\end{array}$ & & & & $\begin{array}{r}-0.5 \\
-0.8 \\
0.7\end{array}$ & \\
\hline $\begin{array}{l}-11-0250 \\
-11-0260 \\
-11-0270\end{array}$ & $\begin{array}{r}98.43 \\
99.67 \\
100.36 \\
101.62\end{array}$ & $\begin{array}{l}22.4 \\
22.9 \\
23.2 \\
23.9\end{array}$ & $\begin{array}{l}22.8 \\
23.3 \\
23.6 \\
24.1\end{array}$ & $\begin{array}{l}0.0729 \\
0.0737 \\
0.0739 \\
0.0739\end{array}$ & $\begin{array}{l}95.16 \\
96.29 \\
96.93 \\
98.25\end{array}$ & $\begin{array}{l}53.02 \\
53.55\end{array}$ & $\begin{array}{r}20.2 \\
7.6 \\
5.2 \\
3.0\end{array}$ & $\begin{array}{r}21.5 \\
8.5 \\
5.5 \\
3.2\end{array}$ & $\begin{array}{r}128 \\
48 \\
33 \\
19\end{array}$ & & & $\begin{array}{l}.41 \\
.06 \\
.54 \\
.59\end{array}$ & & . & $\begin{array}{l}5 . \\
\text { 8. } \\
\text { i. } \\
4 .\end{array}$ & $\begin{array}{l}0 \\
1 \\
4\end{array}$ & 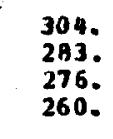 \\
\hline $\begin{array}{r}290 \\
390 \\
310\end{array}$ & $\begin{array}{r}96.82 \\
98.60 \\
99.57 \\
102.44\end{array}$ & $\begin{array}{l}22.7 \\
23.0 \\
24.2\end{array}$ & $\begin{array}{l}2.9 \\
3.3 \\
4.5\end{array}$ & $\begin{array}{l}1363 \\
1361 \\
1357 \\
1360\end{array}$ & $\begin{array}{r}95.30 \\
96.98 \\
97.74 \\
100.27\end{array}$ & 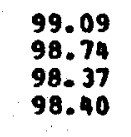 & $\begin{array}{l}7.8 \\
5.2 \\
3.0\end{array}$ & $\begin{array}{r}21.5 \\
8.3 \\
5.5 \\
3.2\end{array}$ & : & $\begin{array}{r}49 \\
35 \\
24\end{array}$ & & 14 & & : & & 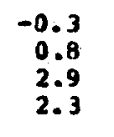 & \\
\hline $\begin{array}{l}B-11 \\
8-1 \\
B-11 \\
B-1\end{array}$ & $\begin{array}{r}98 \\
99 \\
100\end{array}$ & $\begin{array}{l}23.0 \\
23.4\end{array}$ & $\begin{array}{r}.8 \\
.3 \\
.7 \\
.3\end{array}$ & $\begin{array}{l}0 \\
7 \\
3\end{array}$ & $\begin{array}{r}95.68 \\
97.15 \\
97.82 \\
99.21\end{array}$ & 16 & $\begin{array}{l}7.6 \\
5.2 \\
3.0\end{array}$ & $\begin{array}{r}21.5 \\
8.1 \\
5.5 \\
3.2\end{array}$ & $\begin{array}{r}12 \\
16 \\
3 \\
16\end{array}$ & & & $\begin{array}{r}.50 \\
.35 \\
.93\end{array}$ & & & & $\begin{array}{r}-0 \\
-1 \\
0\end{array}$ & i. \\
\hline $\begin{array}{l}8-11-0370 \\
0-11-0380 \\
-11-0390 \\
8-11-0400\end{array}$ & 9 & $\begin{array}{l}23.0 \\
23.9\end{array}$ & $\begin{array}{l}22.3 \\
23.2 \\
24.2 \\
25.2\end{array}$ & $\begin{array}{l}1 \\
7 \\
8 \\
5\end{array}$ & $\begin{array}{r}95.92 \\
97.65 \\
100.05 \\
102.14\end{array}$ & 1 & $\begin{array}{l}2.0 \\
7.6 \\
4.9\end{array}$ & $\begin{array}{l}2.1 \\
8.1 \\
5.2\end{array}$ & & & & $\begin{array}{l}12 \\
19 \\
10\end{array}$ & & & & $\begin{array}{r}89 \\
1 \\
3\end{array}$ & $\begin{array}{l}267 . \\
255 . \\
244 .\end{array}$ \\
\hline $\begin{array}{l}8-11-0410 \\
8-11-0420 \\
8-11-0430\end{array}$ & 109 & 24.5 & $\begin{array}{l}23.7 \\
23.9 \\
24.1 \\
24.4\end{array}$ & $\begin{array}{l}0.0 \\
0.0 \\
0.0\end{array}$ & $\begin{array}{r}94.55 \\
94.83\end{array}$ & $\begin{array}{l}35.59 \\
35.73 \\
35.49\end{array}$ & $\begin{array}{l}7.4 \\
5.0\end{array}$ & $\begin{array}{r}21.8 \\
7.9 \\
5.3 \\
3.1\end{array}$ & $\begin{array}{r}14 \\
51 \\
3 \\
20\end{array}$ & $\begin{array}{l}2 \\
3 \\
8\end{array}$ & $\begin{array}{l}93 . \\
93 . \\
94 .\end{array}$ & 0.70 & $\because$ & . & i. & $\begin{array}{r}-1.1 \\
3.9 \\
4.8 \\
9.5\end{array}$ & $\begin{array}{l}307 . \\
294 . \\
280 .\end{array}$ \\
\hline
\end{tabular}


Toblo C. (ceminaned)

\begin{tabular}{|c|c|c|c|c|c|c|c|c|c|c|c|c|c|c|c|c|c|}
\hline Run No. & $\stackrel{T_{v}}{\mathbf{P}_{\mathbf{p}}}$ & $\underset{(\text { pias) }}{\mathbf{P}}$ & $\begin{array}{c}P_{\text {pata }} \\
\text { (psin) }\end{array}$ & $\underset{(\mathrm{Epm})}{\mathbf{F}_{\mathbf{C}}}$ & 勇 & $\left(1 \mathrm{~b} \mathrm{~b}_{m} / \mathrm{h}\right)$ & $\underset{\left(\mathrm{pm}^{\prime}\right)}{F_{w}}$ & $(i / 1)$ & Re & Trin & $T_{\text {mout }}$ & $\begin{array}{l}\Delta T_{W} \\
(\bullet P)\end{array}$ & $\begin{array}{l}\Delta T \\
P F\end{array}$ & $\begin{array}{c}Q_{c} \\
(B+u / h)\end{array}$ & $a_{(B w / h)}$ & (\%) & $\underset{(m, f)}{u}$ \\
\hline $\begin{array}{l}R-11-0450 \\
R-11-0460 \\
R-11-0470 \\
R=11-0480\end{array}$ & $\begin{array}{r}98.90 \\
101.37 \\
102.79 \\
105.86\end{array}$ & $\begin{array}{l}23.9 \\
24.4 \\
25.0 \\
26.1\end{array}$ & $\begin{array}{l}23.0 \\
24.0 \\
29.6 \\
26.0\end{array}$ & $\begin{array}{c}0.1793 \\
0.1808 \\
0.1812 \\
0.1828\end{array}$ & $\begin{array}{r}96.81 \\
99.13 \\
100.29 \\
103.22\end{array}$ & $\begin{array}{r}130.12 \\
130.94 \\
131.05 \\
131.83\end{array}$ & $\begin{array}{r}20.3 \\
7.4 \\
5.0 \\
2.9\end{array}$ & $\begin{array}{r}21.6 \\
7.9 \\
5.3 \\
3.1\end{array}$ & $\begin{array}{l}93111 . \\
34546 . \\
23589 . \\
13887 .\end{array}$ & $\begin{array}{l}60.61 \\
61.10 \\
61.31 \\
61.01\end{array}$ & $\begin{array}{l}61.65 \\
63.61 \\
64.07 \\
67.27\end{array}$ & $\begin{array}{l}0.99 \\
2.49 \\
3.56 \\
6.26\end{array}$ & $\begin{array}{l}37.77 \\
39.01 \\
39.70 \\
61.73\end{array}$ & $\begin{array}{l}9804 . \\
9835 \\
9826 \\
9847\end{array}$ & $\begin{array}{l}10012 . \\
9204 . \\
8892 . \\
9069 .\end{array}$ & $\begin{array}{r}-2.1 \\
6.4 \\
9.5 \\
7.9\end{array}$ & $\begin{array}{l}234 \\
227 \\
223 \\
213\end{array}$ \\
\hline
\end{tabular}


Table C.19. Exportineated enta for R-11 condending on Twbe $R$

\begin{tabular}{|c|c|c|c|c|c|c|c|c|c|c|c|c|c|c|c|c|c|}
\hline R & Py & $\underset{\text { (pin) }}{\mathbf{P}}$ & a) & $\underset{(\mathbf{e p m})}{\boldsymbol{F}_{\boldsymbol{c}}}$ & Pُ & $m_{n,}(n)$ & $\underset{(\mathrm{spm})}{\mathbf{F}_{\mathbf{w}}}$ & $(m+1)$ & $R_{t}$ & Trin & $T_{\text {prom }}$ & $T_{m}$ & 'T) & (m) & (h) & b) & $\underset{n}{U(m u /}$ \\
\hline $\begin{array}{r}-11-0012 \\
-11-0028 \\
-11-0038 \\
-11-0048\end{array}$ & $\begin{array}{l}102.04 \\
103.44 \\
103.76 \\
104.79\end{array}$ & $\begin{array}{l}24.6 \\
25.0 \\
25.1 \\
25.5\end{array}$ & $\begin{array}{l}24.3 \\
24.9 \\
25.9 \\
25.5\end{array}$ & $\begin{array}{l}0.0559 \\
0.0551 \\
0.0551 \\
0.0551\end{array}$ & $\begin{array}{l}97.19 \\
98.21 \\
98.62 \\
99.33\end{array}$ & $\begin{array}{r}40.59 \\
39.93 \\
39.91 \\
39.89\end{array}$ & $\begin{array}{r}20.8 \\
7.6 \\
5.2 \\
3.0\end{array}$ & $\begin{array}{r}20.1 \\
7.3 \\
5.0 \\
2.9\end{array}$ & $\begin{array}{c}57720 \\
21228 \\
14499 \\
8364 .\end{array}$ & $\begin{array}{l}97.09 \\
97.45 \\
97.13 \\
96.70\end{array}$ & $\begin{array}{l}97.41 \\
98.23 \\
98.23 \\
98.64\end{array}$ & $\begin{array}{l}0.28 \\
0.78 \\
1.10 \\
1.96\end{array}$ & $\begin{array}{l}4.79 \\
5.59 \\
6.08 \\
7.12\end{array}$ & $\begin{array}{l}3046 . \\
2991 . \\
2989 . \\
2983 .\end{array}$ & $\begin{array}{l}2865 . \\
2948 . \\
2855 . \\
2929 .\end{array}$ & $\begin{array}{l}5.9 \\
1.5 \\
4.5 \\
1.8\end{array}$ & $\begin{array}{l}561 . \\
471 . \\
433 . \\
369 .\end{array}$ \\
\hline $\begin{array}{l}2-11-005 \mathrm{R} \\
-11-0068 \\
-11-007 \mathrm{R} \\
\mathrm{a}-11-008 \mathrm{~B}\end{array}$ & $\begin{array}{r}96.58 \\
102.12 \\
105.15 \\
110.97\end{array}$ & $\begin{array}{l}22.3 \\
24.4 \\
.25 .6 \\
28.2\end{array}$ & $\begin{array}{l}2.1 \\
4.3 \\
5.7 \\
8.4\end{array}$ & $\begin{array}{l}0.2174 \\
0.2194 \\
0.2198 \\
0.2213\end{array}$ & $\begin{array}{r}95.32 \\
100.25 \\
103.02 \\
108.45\end{array}$ & $\begin{array}{l}158.01 \\
158.68 \\
158.59 \\
158.87\end{array}$ & $\begin{array}{r}20.6 \\
7.6 \\
5.2 \\
3.0\end{array}$ & $\begin{array}{r}19.9 \\
7.3 \\
5.0 \\
2.9\end{array}$ & $\begin{array}{c}39466 \\
14869 \\
10285 \\
6064\end{array}$ & $\begin{array}{l}66.17 \\
66.75 \\
66.87 \\
66.94\end{array}$ & $\begin{array}{l}67.39 \\
69.86 \\
71.33 \\
74.50\end{array}$ & $\begin{array}{l}1.17 \\
3.09 \\
. .44 \\
7.54\end{array}$ & $\begin{array}{l}29.80 \\
33.82 \\
36.05 \\
40.25\end{array}$ & & $\begin{array}{l}7 . \\
1.9 \\
9 .\end{array}$ & $\begin{array}{r}-1.1 \\
1.5 \\
2.7 \\
4.2\end{array}$ & $\begin{array}{l}353 . \\
310 . \\
290 . \\
258 .\end{array}$ \\
\hline $\begin{array}{l}=11-0098 \\
=-11-0108 \\
-11-0112 \\
-11-0128\end{array}$ & $\begin{array}{c}101.22 \\
103.20 \\
103.94 \\
105.54\end{array}$ & $\begin{array}{l}24.1 \\
24.8 \\
25.1 \\
25.7\end{array}$ & $\begin{array}{l}24.0 \\
24.8 \\
25.1 \\
25.8\end{array}$ & $\begin{array}{l}0.0701 \\
0.0721 \\
0.0713 \\
0.0704\end{array}$ & $\begin{array}{r}96.96 \\
99.35 \\
99.83 \\
100.91\end{array}$ & $\begin{array}{l}50.84 \\
52.21 \\
51.58 \\
50.92\end{array}$ & $\begin{array}{r}20.8 \\
7.6 \\
5.2 \\
3.0\end{array}$ & $\begin{array}{r}20.1 \\
7.3 \\
5.0 \\
2.9\end{array}$ & $\begin{array}{c}56046 \\
20631 . \\
14138 \\
8197\end{array}$ & $\begin{array}{l}94.25 \\
94.61 \\
94.52 \\
94.46\end{array}$ & $\begin{array}{l}94.66 \\
95.64 \\
96.00 \\
96.95\end{array}$ & $\begin{array}{r}0.37 \\
1.03 \\
1.49 \\
3.51\end{array}$ & $\begin{array}{l}6.76 \\
8.08 \\
8.68 \\
9.83\end{array}$ & $\begin{array}{l}3819 . \\
3913 . \\
3862 . \\
3805\end{array}$ & $\begin{array}{l}3833 . \\
3891 . \\
3849 . \\
3746 .\end{array}$ & $\begin{array}{r}-0.4 \\
0.6 \\
0.3 \\
1.6\end{array}$ & $\begin{array}{l}497 . \\
427 . \\
392 . \\
341 .\end{array}$ \\
\hline $\begin{array}{l}A-11-0138 \\
\mathrm{R}-11-0148 \\
-11-0158 \\
8-11-0168\end{array}$ & $\begin{array}{r}97.39 \\
101.70 \\
104.97 \\
109.69\end{array}$ & $\begin{array}{l}21.5 \\
24.1 \\
25.2 \\
27.4\end{array}$ & $\begin{array}{l}22.4 \\
24.2 \\
25.4 \\
27.7\end{array}$ & $\begin{array}{l}0.2033 \\
0.2007 \\
0.2015 \\
0.2027\end{array}$ & $\begin{array}{r}96.22 \\
99.97 \\
102.59 \\
107.36\end{array}$ & $\begin{array}{l}147.65 \\
145.21 \\
145.43 \\
145.64\end{array}$ & $\begin{array}{r}20.6 \\
7.6 \\
5.1 \\
3.0\end{array}$ & $\begin{array}{r}19.9 \\
7.3 \\
6.9 \\
2.9\end{array}$ & $\begin{array}{l}91090^{\circ} \\
15425 \\
10413 \\
6242\end{array}$ & $\begin{array}{l}69.18 \\
69.58 \\
69.35 \\
69.57\end{array}$ & $\begin{array}{l}70.30 \\
72.46 \\
73.59 \\
76.46\end{array}$ & $\begin{array}{l}1.08 \\
2.87 \\
6.23 \\
6.87\end{array}$ & $\begin{array}{l}27.64 \\
30.68 \\
33.09 \\
36.68\end{array}$ & $\begin{array}{l}11144 . \\
10902 . \\
10882 . \\
10826 .\end{array}$ & & $\begin{array}{r}0.5 \\
-0.0 \\
0.9 \\
5.0\end{array}$ & $\begin{array}{l}355 . \\
313 . \\
290 . \\
260 .\end{array}$ \\
\hline $\begin{array}{l}0-11-0178 \\
-11-0188 \\
-11-0198 \\
-11-0208\end{array}$ & $\begin{array}{r}100.13 \\
101.62 \\
102.46 \\
104.68\end{array}$ & $\begin{array}{l}23.5 \\
24.1 \\
24.4\end{array}$ & $\begin{array}{l}23.5 \\
24.1 \\
24.5 \\
25.5\end{array}$ & $\begin{array}{l}0.0937 \\
0.0930 \\
0.0926 \\
0.0922\end{array}$ & $\begin{array}{r}96.63 \\
97.97 \\
98.62 \\
100.45\end{array}$ & $\begin{array}{l}68.00 \\
67.46 \\
67.11 \\
66.69\end{array}$ & $\begin{array}{r}20.8 \\
7.5 \\
5.2 \\
3.0\end{array}$ & $\begin{array}{r}20.1 \\
7.2 \\
5.0 \\
2.9\end{array}$ & $\begin{array}{c}53389 . \\
19249 . \\
73363 . \\
7765 .\end{array}$ & $\begin{array}{l}89.92 \\
89.99 \\
89.33 \\
89.30\end{array}$ & $\begin{array}{l}90 \\
90 \\
91\end{array}$ & $\begin{array}{l}0.50 \\
1.36 \\
1.91\end{array}$ & $\begin{array}{r}9.94 \\
11.94 \\
12.17\end{array}$ & $\begin{array}{l}5115 . \\
5065 \\
5034\end{array}$ & & $\begin{array}{r}-1.3 \\
-1.9 \\
1.5\end{array}$ & $\begin{array}{l}453 . \\
390 . \\
364 . \\
319 .\end{array}$ \\
\hline $\begin{array}{l}R-11-021 R \\
R-11-0228 \\
2-11-0238 \\
R-11-0248\end{array}$ & $\begin{array}{r}97.63 \\
101.24 \\
104.01 \\
108.26\end{array}$ & $\begin{array}{l}22.9 \\
23.9 \\
25.1 \\
26.9\end{array}$ & $\begin{array}{l}22.5 \\
24.0 \\
25.2 \\
27.1\end{array}$ & $\begin{array}{l}0.1770 \\
0.1754 \\
0.1779 \\
0.1773\end{array}$ & $\begin{array}{r}96.07 \\
99.41 \\
102.11 \\
106.02\end{array}$ & $\begin{array}{r}128.58 \\
126.99 \\
128.49 \\
127.54\end{array}$ & $\begin{array}{r}20.6 \\
7.6 \\
5.2 \\
3.0\end{array}$ & $\begin{array}{r}19.9 \\
7.3 \\
5.0 \\
2.9\end{array}$ & $\begin{array}{l}43794 . \\
16319 . \\
11269 . \\
6595 .\end{array}$ & $\begin{array}{l}74.08 \\
74.015 \\
74.31 \\
74.19\end{array}$ & $\begin{array}{l}75.06 \\
76.7 .1 \\
77.99 \\
80.34\end{array}$ & $\begin{array}{l}0.94 \\
2.55 \\
3.66 \\
6.14\end{array}$ & $\begin{array}{l}23.06 \\
25.81 \\
27.86 \\
30.99\end{array}$ & & & $\begin{array}{r}0.3 \\
-1.3 \\
1.3 \\
3.3\end{array}$ & $\begin{array}{l}371 . \\
326 . \\
304 . \\
270 .\end{array}$ \\
\hline $\begin{array}{l}\mathrm{a}-11-025 \mathrm{R} \\
\mathrm{a}-11-026 \mathrm{R} \\
\mathrm{R}-11-027 \mathrm{R} \\
-11-028 \mathrm{R}\end{array}$ & $\begin{array}{l}99.55 \\
108.26 \\
102.53 \\
105.29\end{array}$ & $\begin{array}{l}23.0 \\
23.7 \\
24.7 \\
25.5\end{array}$ & $\begin{array}{l}23.3 \\
24.0 \\
24.5 \\
25.7\end{array}$ & $\begin{array}{l}0.1115 \\
0.1106 \\
0.1114 \\
0.1114\end{array}$ & $\begin{array}{r}96.38 \\
98.01 \\
99.13 \\
101.55\end{array}$ & $\begin{array}{l}80.93 \\
80.20 \\
80.69 \\
80.48\end{array}$ & $\begin{array}{r}20.7 \\
7.6 \\
5.2 \\
3.0\end{array}$ & $\begin{array}{r}20.0 \\
7.3 \\
5.0 \\
2.9\end{array}$ & $\begin{array}{l}51208 . \\
18781 . \\
12866 \\
7480\end{array}$ & $\begin{array}{l}86.72 \\
86.13 \\
85.89 \\
85.67\end{array}$ & $\begin{array}{l}87.34 \\
87.75 \\
88.21 \\
89.72\end{array}$ & $\begin{array}{l}0.58 \\
1.61 \\
2.32\end{array}$ & $\begin{array}{r}12.52 \\
14.32 \\
15.48 \\
17.59\end{array}$ & & $\begin{array}{l}9 . \\
6 . \\
6 . \\
3 .\end{array}$ & $\begin{array}{r}2.4 \\
-1.4 \\
0.8 \\
-0.6\end{array}$ & $\begin{array}{l}429 . \\
371 . \\
344 . \\
301 .\end{array}$ \\
\hline $\begin{array}{l}R-11-029 R \\
R-11-030 R \\
R-11-031 R \\
R-11-032 R\end{array}$ & $\begin{array}{r}98.15 \\
101.08 \\
103.85 \\
108.21\end{array}$ & $\begin{array}{l}22.7 \\
24.0 \\
25.2 \\
26.7\end{array}$ & $\begin{array}{l}22.7 \\
23.9 \\
25.1 \\
27.1\end{array}$ & $\begin{array}{l}0.1557 \\
0.1544 \\
0.1568 \\
0.1573\end{array}$ & $\begin{array}{r}96.07 \\
98.67 \\
101.22 \\
105.22\end{array}$ & $\begin{array}{r}113.05 \\
111.88 \\
113.32 \\
113.29\end{array}$ & $\begin{array}{r}20.7 \\
7.6 \\
5.2 \\
3.0\end{array}$ & $\begin{array}{r}20.0 \\
7.3 \\
5.0 \\
2.9\end{array}$ & $\begin{array}{l}46389 . \\
17147 . \\
11880 \\
6976\end{array}$ & $\begin{array}{l}78.36 \\
78.21 \\
78.71 \\
79.01\end{array}$ & $\begin{array}{l}79.21 \\
60.43 \\
81.95 \\
84.49\end{array}$ & $\begin{array}{l}0.82 \\
2.22 \\
3.24 \\
5.48\end{array}$ & $\begin{array}{l}19.37 \\
21.75 \\
23.52 \\
26.45\end{array}$ & $\begin{array}{l}8525 \\
8407 \\
8486 \\
8437\end{array}$ & $\begin{array}{l}8479 . \\
8414 . \\
8408 . \\
8206 .\end{array}$ & $\begin{array}{r}0.5 \\
-0.1 \\
0.9 \\
2.7\end{array}$ & $\begin{array}{l}388 . \\
340 . \\
318 . \\
201 .\end{array}$ \\
\hline $\begin{array}{l}\mathrm{R}-11-033 \mathrm{R} \\
\mathrm{B}-11-034 \mathrm{R} \\
\mathrm{R}-11-035 \mathrm{R} \\
\mathrm{R}-11-036 \mathrm{R} \\
\end{array}$ & $\begin{array}{r}98.25 \\
100.60 \\
102.10 \\
105.49 \\
\end{array}$ & $\begin{array}{l}22.7 \\
23.7 \\
24.9 \\
25.9\end{array}$ & $\begin{array}{l}22.7 \\
23.7 \\
24.3\end{array}$ & $\begin{array}{l}0.1355 \\
0.1345 \\
0.1339 \\
0.1340 \\
\end{array}$ & $\begin{array}{r}96.09 \\
98.09 \\
99.39 \\
102.44 \\
\end{array}$ & $\begin{array}{l}98.43 \\
97.50 \\
96.93 \\
96.77 \\
\end{array}$ & $\begin{array}{r}20.7 \\
7.6 \\
5.2 \\
3.0 \\
\end{array}$ & $\begin{array}{r}20.0 \\
7.3 \\
5.0 \\
2.9 \\
\end{array}$ & $\begin{array}{r}48386 . \\
17831 . \\
12241 . \\
7148 . \\
\end{array}$ & $\begin{array}{l}81.81 \\
81.52 \\
81.36 \\
81.40 \\
\end{array}$ & $\begin{array}{l}82.56 \\
83.45 \\
84.16 \\
86.11 \\
\end{array}$ & $\begin{array}{l}0.72 \\
1.94 \\
2.60 \\
4.71 \\
\end{array}$ & $\begin{array}{l}16.07 \\
18.12 \\
19.34 \\
21.74 \\
\end{array}$ & $\begin{array}{l}7422 . \\
7331 . \\
7274 . \\
7231 .\end{array}$ & $\begin{array}{l}7405 . \\
7341 . \\
7254 . \\
7051 .\end{array}$ & $\begin{array}{r}0.2 \\
-0.1 \\
0.3 \\
2.5 \\
\end{array}$ & $\begin{array}{l}407 . \\
357 . \\
331 . \\
293 . \\
\end{array}$ \\
\hline
\end{tabular}


Table C.11. Expertmeatal denta for R-11 condenaing on Tube S

\begin{tabular}{|c|c|c|c|c|c|c|c|c|c|c|c|c|c|c|c|c|c|}
\hline Run No. & ('P & $\underset{\text { (psia) }}{\mathbf{p}}$ & $\begin{array}{c}\mathbf{P}_{\text {ssul }} \\
\text { (psia) }\end{array}$ & $\underset{(\mathbf{E p m})}{\mathbf{F}_{\mathbf{c}}}$ & $\begin{array}{c}T_{C} \\
\left(P^{-F}\right)\end{array}$ & $\left(1 b_{m}^{m} f_{h}\right)$ & $\underset{(\mathbf{f p m}}{\mathbf{F}_{\boldsymbol{W}}}$ & $(n+1 / s)$ & Re & 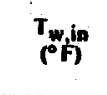 & $\boldsymbol{T}_{\text {wowl }}$ & $\underset{(\mathbf{P})}{\Delta T_{w}}$ & $\underset{(P)}{\Delta T}$ & $\underset{\left(B_{1}(u / h)\right.}{Q_{c}}$ & $\underset{(B(u / h)}{Q_{w}}$ & $\underset{(\%)}{\Delta}$ & 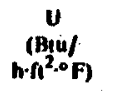 \\
\hline $\begin{array}{l}n-11-0015 \\
8-11-0025 \\
8-11-0035 \\
8-11-0045\end{array}$ & $\begin{array}{r}98.41 \\
101.28 \\
102.57 \\
105.24\end{array}$ & $\begin{array}{l}22.7 \\
23.9 \\
24.5 \\
25.7\end{array}$ & $\begin{array}{l}22.8 \\
24.0 \\
24.5 \\
25.7\end{array}$ & $\begin{array}{l}0.1337 \\
0.1330 \\
0.1326 \\
0.1330\end{array}$ & $\begin{array}{r}96.46 \\
98.95 \\
100.13 \\
102.29\end{array}$ & $\begin{array}{l}97.03 \\
96.35 \\
95.95 \\
96.02\end{array}$ & $\begin{array}{r}18.9 \\
7.6 \\
5.2 \\
3.0\end{array}$ & $\begin{array}{r}19.1 \\
7.7 \\
5.3 \\
3.0\end{array}$ & $\begin{array}{c}46360 . \\
18962 . \\
13037 . \\
7579 .\end{array}$ & $\begin{array}{l}62.95 \\
83.82 \\
63.79 \\
63.53\end{array}$ & $\begin{array}{l}83.78 \\
85.73 \\
86.57 \\
86.11\end{array}$ & $\begin{array}{l}0.79 \\
1.92 \\
2.78 \\
4.58\end{array}$ & $\begin{array}{l}15.04 \\
16.51 \\
77.39 \\
19.42\end{array}$ & $\begin{array}{l}7315 . \\
7236 . \\
7196 \\
7177 .\end{array}$ & $\begin{array}{l}7468 . \\
7268 . \\
7204 . \\
6862 .\end{array}$ & $\begin{array}{r}-2.1 \\
-0.4 \\
-0.1 \\
4.4\end{array}$ & $\begin{array}{l}459 . \\
414 . \\
390 . \\
349 .\end{array}$ \\
\hline $\begin{array}{l}8-11-0055 \\
8-11-0065 \\
8-11-0075 \\
8-11-0085\end{array}$ & $\begin{array}{l}101.20 \\
101.72 \\
102.27 \\
103.48\end{array}$ & $\begin{array}{l}24.0 \\
24.2 \\
24.5 \\
25.0\end{array}$ & $\begin{array}{l}24.0 \\
24.2 \\
24.4 \\
24.9\end{array}$ & $\begin{array}{l}0.0634 \\
0.0627 \\
0.0627 \\
0.0627\end{array}$ & $\begin{array}{l}96.76 \\
97.08 \\
97.59 \\
98.56\end{array}$ & $\begin{array}{l}46.00 \\
45.52 \\
45.50 \\
45.46\end{array}$ & $\begin{array}{r}19.0 \\
7.6 \\
5.2 \\
3.0\end{array}$ & $\begin{array}{r}19.2 \\
7.7 \\
5.3 \\
3.0\end{array}$ & $\begin{array}{r}53766 . \\
21470 \\
14702 . \\
8503\end{array}$ & $\begin{array}{l}95.61 \\
95.21 \\
95.09 \\
94.86\end{array}$ & $\begin{array}{l}96.02 \\
96.11 \\
96.39 \\
97.07\end{array}$ & $\begin{array}{l}0.37 \\
0.90 \\
1.30 \\
2.23\end{array}$ & $\begin{array}{l}5.38 \\
6.06 \\
6.53 \\
7.52\end{array}$ & $\begin{array}{l}3456 . \\
3418 . \\
3414 . \\
3406 .\end{array}$ & $\begin{array}{l}3511 . \\
3396 . \\
3370 . \\
3328 .\end{array}$ & $\begin{array}{r}-1.6 \\
0.6 \\
1.3 \\
2.3\end{array}$ & $\begin{array}{l}606 . \\
532 . \\
493 . \\
427 .\end{array}$ \\
\hline $\begin{array}{l}8-11-0095 \\
8-11-0105 \\
8-11-0115 \\
8-11-0125\end{array}$ & $\begin{array}{l}102.74 \\
106.68 \\
109.04 \\
114.13\end{array}$ & $\begin{array}{l}24.7 \\
26.4 \\
27.4 \\
29.5\end{array}$ & $\begin{array}{l}24.6 \\
26.4 \\
27.4 \\
29.9\end{array}$ & $\begin{array}{l}0.2123 \\
0.2112 \\
0.2110 \\
0.2099\end{array}$ & $\begin{array}{l}100.91 \\
104.50 \\
106.77 \\
111.52\end{array}$ & $\begin{array}{l}153.51 \\
152.20 \\
151.67 \\
150.24\end{array}$ & $\begin{array}{r}16.7 \\
7.6 \\
5.2 \\
3.0\end{array}$ & $\begin{array}{r}18.9 \\
7.7 \\
5.3 \\
3.0\end{array}$ & $\begin{array}{r}36677 \\
16025 \\
11045 \\
6524\end{array}$ & $\begin{array}{l}69.25 \\
69.80 \\
69.71 \\
70.00\end{array}$ & $\begin{array}{l}70.57 \\
72.89 \\
74.08 \\
77.62\end{array}$ & $\begin{array}{l}1.27 \\
3.08 \\
4.35 \\
7.61\end{array}$ & $\begin{array}{l}32.83 \\
35.33 \\
37.15 \\
40.33\end{array}$ & $\begin{array}{l}11511 . \\
11357 . \\
11284 . \\
11105 .\end{array}$ & $\begin{array}{l}11849 . \\
11689 . \\
11298 \\
11388\end{array}$ & $\begin{array}{l}-2.9 \\
-2.9 \\
-0.1 \\
-2.6\end{array}$ & $\begin{array}{l}331 . \\
303 . \\
287 . \\
260 .\end{array}$ \\
\hline $\begin{array}{l}R-11-0135 \\
8-11-0145 \\
8-11-015 S \\
-11-0165\end{array}$ & $\begin{array}{r}90.64 \\
99.75 \\
100.70 \\
102.98\end{array}$ & $\begin{array}{l}23.0 \\
23.4 \\
23.9 \\
24.8\end{array}$ & $\begin{array}{l}22.9 \\
23.4 \\
23.7 \\
24.7\end{array}$ & $\begin{array}{l}0.0982 \\
0.0970 \\
0.0968 \\
0.0969\end{array}$ & $\begin{array}{l}95.43 \\
96.40 \\
97.27 \\
99.45\end{array}$ & $\begin{array}{l}71.37 \\
70.41 \\
70.20 \\
70.19\end{array}$ & $\begin{array}{r}19.0 \\
7.6 \\
5.2 \\
3.0\end{array}$ & $\begin{array}{r}19.2 \\
7.7 \\
5.3 \\
3.0\end{array}$ & $\begin{array}{r}49716 . \\
19908 . \\
1365 . \\
7957 .\end{array}$ & $\begin{array}{l}68.62 \\
88.31 \\
68.25 \\
88.39\end{array}$ & $\begin{array}{l}99.25 \\
89.74 \\
90.28 \\
91.81\end{array}$ & $\begin{array}{l}0.59 \\
1.41 \\
2.04 \\
3.43\end{array}$ & $\begin{array}{r}9.71 \\
10.73 \\
11.44 \\
12.88\end{array}$ & $\begin{array}{l}5379 . \\
5299 . \\
5277 . \\
5261 .\end{array}$ & $\begin{array}{l}5555 . \\
5356 . \\
5276 . \\
5119 .\end{array}$ & $\begin{array}{r}-3.3 \\
-1.1 \\
0.0 \\
2.7\end{array}$ & $\begin{array}{l}523 . \\
466 . \\
435 . \\
385 .\end{array}$ \\
\hline $\begin{array}{l}R-11-0175 \\
R-11-0185 \\
R-11-0195 \\
R-11-0205\end{array}$ & $\begin{array}{r}98.70 \\
102.14 \\
104.61 \\
108.99\end{array}$ & $\begin{array}{l}23.0 \\
24.5 \\
25.6 \\
27.5\end{array}$ & $\begin{array}{l}22.9 \\
24.4 \\
25.4 \\
27.4\end{array}$ & $\begin{array}{l}0.1953 \\
0.1943 \\
0.1958 \\
0.1950\end{array}$ & $\begin{array}{r}97.27 \\
100.35 \\
102.63 \\
106.65\end{array}$ & $\begin{array}{l}141.68 \\
140.53 \\
141.35 \\
140.18\end{array}$ & $\begin{array}{r}18.7 \\
7.6 \\
5.2 \\
3.0\end{array}$ & $\begin{array}{r}18.9 \\
7.7 \\
5.3 \\
3.0\end{array}$ & $\begin{array}{c}39220 . \\
16201 . \\
11183 . \\
6589 .\end{array}$ & $\begin{array}{l}70.35 \\
70.90 \\
70.92 \\
71.16\end{array}$ & $\begin{array}{l}71.55 \\
73.68 \\
74.99 \\
77.96\end{array}$ & $\begin{array}{l}1.15 \\
2.76 \\
4.05 \\
6.79\end{array}$ & $\begin{array}{l}27.75 \\
29.85 \\
31.65 \\
34.43\end{array}$ & $\begin{array}{l}10677 . \\
10546 . \\
10575 . \\
10429\end{array}$ & $\begin{array}{l}10746 . \\
10484 . \\
10509 . \\
10156 .\end{array}$ & $\begin{array}{r}-0.6 \\
0.6 \\
0.6 \\
2.6\end{array}$ & $\begin{array}{l}363 . \\
333 . \\
315 . \\
286 .\end{array}$ \\
\hline $\begin{array}{l}R-11-0215 \\
2-11-022 S \\
R-11-0235 \\
R-1+024 S\end{array}$ & $\begin{array}{r}99.79 \\
100.66 \\
101.45 \\
103.00\end{array}$ & $\begin{array}{l}23.4 \\
23.8 \\
24.2 \\
24.9\end{array}$ & $\begin{array}{l}23.4 \\
23.7 \\
24.1 \\
24.7\end{array}$ & $\begin{array}{l}0.0777 \\
0.0765 \\
0.0769 \\
0.0767\end{array}$ & $\begin{array}{l}96.01 \\
96.80 \\
97.44 \\
98.91\end{array}$ & $\begin{array}{l}56.45 \\
55.49 \\
55.76 \\
55.53\end{array}$ & $\begin{array}{r}19.0 \\
7.6 \\
5.2 \\
3.0\end{array}$ & $\begin{array}{r}19.2 \\
7.7 \\
5.3 \\
3.0\end{array}$ & $\begin{array}{r}51963 . \\
20790^{\circ} \\
14265 . \\
8274 .\end{array}$ & $\begin{array}{l}92.53 \\
92.24 \\
92.26 \\
92.19\end{array}$ & $\begin{array}{l}93.03 \\
93.36 \\
93.85 \\
94.86\end{array}$ & $\begin{array}{l}0.47 \\
1.12 \\
1.59 \\
2.68\end{array}$ & $\begin{array}{l}7.01 \\
7.87 \\
8.40 \\
9.48\end{array}$ & $\begin{array}{l}4249 . \\
4172 . \\
4188 . \\
4163 .\end{array}$ & $\begin{array}{l}4410 . \\
4228 . \\
4113 . \\
4011 .\end{array}$ & $\begin{array}{r}-3.8 \\
-1.4 \\
1.8 \\
3.7\end{array}$ & $\begin{array}{l}572 . \\
500 . \\
470 . \\
414 .\end{array}$ \\
\hline $\begin{array}{l}R-11-025 S \\
R-11-026 S \\
R-11-027 S \\
R-11-028 S\end{array}$ & $\begin{array}{r}96.95 \\
99.93 \\
101.85 \\
105.70\end{array}$ & $\begin{array}{l}22.3 \\
23.5 \\
24.3 \\
26.0\end{array}$ & $\begin{array}{l}22.2 \\
23.4 \\
24.2 \\
25.9\end{array}$ & $\begin{array}{l}0.1734 \\
0.1723 \\
0.1728 \\
0.1728\end{array}$ & $\begin{array}{r}95.54 \\
90.19 \\
99.93 \\
103.39\end{array}$ & $\begin{array}{l}125.97 \\
124.87 \\
125.02 \\
124.61\end{array}$ & $\begin{array}{r}18.7 \\
7.6 \\
5.2 \\
3.0\end{array}$ & $\begin{array}{r}18.9 \\
7.7 \\
5.3 \\
3.0\end{array}$ & $\begin{array}{r}40931 . \\
16867 . \\
11609 \\
6818 .\end{array}$ & $\begin{array}{l}73.78 \\
74.14 \\
74.03 \\
74.22\end{array}$ & $\begin{array}{l}74.83 \\
76.61 \\
77.63 \\
80.22\end{array}$ & $\begin{array}{l}1.02 \\
2.46 \\
3.58 \\
5.97\end{array}$ & $\begin{array}{l}22.65 \\
24.56 \\
26.02 \\
28.48\end{array}$ & $\begin{array}{l}9513 . \\
9396 . \\
9385 . \\
9310 .\end{array}$ & $\begin{array}{l}9507 . \\
9312 . \\
9298 . \\
8929 .\end{array}$ & $\begin{array}{l}0.1 \\
0.9 \\
0.9 \\
4.1\end{array}$ & $\begin{array}{l}396 . \\
361 . \\
340 . \\
308 .\end{array}$ \\
\hline $\begin{array}{l}8-11-029 S \\
R-11-0305 \\
R-11-0315 \\
R-11-0325\end{array}$ & $\begin{array}{r}100.13 \\
100.52 \\
100.61 \\
99.61\end{array}$ & $\begin{array}{l}23.5 \\
23.7 \\
23.9 \\
23.9\end{array}$ & $\begin{array}{l}23.5 \\
23.7 \\
23.6 \\
23.3\end{array}$ & $\begin{array}{l}0.0473 \\
0.0466 \\
0.0468 \\
0.1167\end{array}$ & $\begin{array}{l}95.05 \\
95.43 \\
95.76 \\
97.38\end{array}$ & $\begin{array}{l}34.36 \\
33.88 \\
34.02 \\
84.62\end{array}$ & $\begin{array}{r}19.0 \\
7.6 \\
5.2 \\
19.0\end{array}$ & $\begin{array}{r}19.2 \\
7.7 \\
5.3 \\
19.2\end{array}$ & $\begin{array}{l}54038 . \\
21584 . \\
14756 . \\
48842 .\end{array}$ & $\begin{array}{l}96.25 \\
95.94 \\
95.74 \\
87.06\end{array}$ & $\begin{array}{l}96.58 \\
96.63 \\
96.69 \\
87.78\end{array}$ & $\begin{array}{l}0.29 \\
0.69 \\
0.95 \\
0.67\end{array}$ & $\begin{array}{r}3.72 \\
4.23 \\
4.59 \\
12.19\end{array}$ & $\begin{array}{l}2585 . \\
2547 \\
2557 \\
6370\end{array}$ & $\begin{array}{l}2702 . \\
2612 . \\
2451 . \\
6388 .\end{array}$ & $\begin{array}{r}-4.5 \\
-2.5 \\
4.1 \\
-0.3\end{array}$ & $\begin{array}{l}656 . \\
568 . \\
525 . \\
493 .\end{array}$ \\
\hline $\begin{array}{l}8-11-0335 \\
R-11-034 s \\
8-11-035 s\end{array}$ & $\begin{array}{r}101.62 \\
102.85 \\
105.56\end{array}$ & $\begin{array}{l}24.2 \\
24.7 \\
25.9\end{array}$ & $\begin{array}{l}24.1 \\
24.7 \\
25.8\end{array}$ & $\begin{array}{l}0.1172 \\
0.1168 \\
0.1175\end{array}$ & $\begin{array}{r}98.93 \\
100.19 \\
102.65\end{array}$ & $\begin{array}{l}84.92 \\
84.51 \\
84.63\end{array}$ & $\begin{array}{l}7.6 \\
5.2 \\
3.0\end{array}$ & $\begin{array}{l}7.7 \\
5.3 \\
3.0\end{array}$ & $\begin{array}{c}19627 \\
13495 \\
7859\end{array}$ & $\begin{array}{l}86.96 \\
87.00 \\
86.90\end{array}$ & $\begin{array}{l}88.67 \\
89.45 \\
91.16\end{array}$ & $\begin{array}{l}1.71 \\
2.45 \\
4.27\end{array}$ & $\begin{array}{l}13.81 \\
14.62 \\
16.53\end{array}$ & $\begin{array}{l}6377 . \\
6336 . \\
6339 .\end{array}$ & $\begin{array}{l}6480 . \\
6353 \\
6375\end{array}$ & $\begin{array}{l}-1.7 \\
-0.3 \\
-0.6\end{array}$ & $\begin{array}{l}436 . \\
409 . \\
362 .\end{array}$ \\
\hline
\end{tabular}


Tuble C.12. Expertwentat datin for R-11 condensing on Tube T

\begin{tabular}{|c|c|c|c|c|c|c|c|c|c|c|c|c|c|c|c|c|c|}
\hline$R_{!}$ & $T_{y}$ & $P$ & a & c & $T_{c}$ & in & 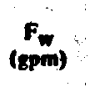 & $v$ & Re & (Pin & $T_{\text {y.out }}$ & & $\begin{array}{l}T \\
\text { F }\end{array}$ & 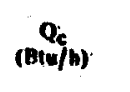 & $\frac{Q_{w}}{a+/ h)}$ & $\stackrel{\Delta}{(\%)}$ & $\begin{array}{c}u \\
\text { (nivf } \\
f^{2} \cdot{ }^{\prime}\end{array}$ \\
\hline $32 x$ & 15.58 & $\begin{array}{l}25.4 \\
26.3 \\
28.2\end{array}$ & $\begin{array}{l}4.9 \\
5.9 \\
8.2\end{array}$ & $\begin{array}{l}0.1348 \\
0.1326 \\
0.1329 \\
0.1330\end{array}$ & $\begin{array}{r}97.88 \\
100.45 \\
102.31 \\
107.20\end{array}$ & $\begin{array}{l}7.74 \\
5.92 \\
5.95\end{array}$ & $\begin{array}{r}22.0 \\
7.5 \\
5.2 \\
3.0\end{array}$ & $\begin{array}{r}17.7 \\
6.0 \\
4.2 \\
2.4\end{array}$ & $\begin{array}{l}5 . \\
5 . \\
\text { 5. }\end{array}$ & $\begin{array}{l}9 \\
8 \\
7\end{array}$ & & & $\begin{array}{l}1 \\
6 \\
0\end{array}$ & & & $\begin{array}{l}- \\
\overline{-}\end{array}$ & $\begin{array}{l}359 . \\
310 . \\
238 .\end{array}$ \\
\hline $\begin{array}{l}-11-0052 \\
-11-0062 \\
-11-0079 \\
-11-0082\end{array}$ & $\begin{array}{r}99.67 \\
107.13 \\
111.67\end{array}$ & $\begin{array}{l}23.9 \\
26.6 \\
28.7 \\
33.3\end{array}$ & $\begin{array}{r}3.4 \\
6.6 \\
8.7 \\
3.3\end{array}$ & $\begin{array}{l}0.2426 \\
0.2425 \\
0.2423 \\
0.2420\end{array}$ & $\begin{array}{r}98.11 \\
104.79 \\
109.12 \\
117.52\end{array}$ & $\begin{array}{l}87 \\
.67 \\
62 \\
.14\end{array}$ & $\begin{array}{r}22.0 \\
7.6 \\
5.2\end{array}$ & 2. & & $\begin{array}{l}.77 \\
647 \\
.53 \\
.57\end{array}$ & & & $\begin{array}{l}48 \\
93 \\
66 \\
88\end{array}$ & & & $\begin{array}{r}-0.1 \\
-0.0 \\
0.3\end{array}$ & $\begin{array}{l}367 . \\
291: \\
254 . \\
202 .\end{array}$ \\
\hline $\begin{array}{l}-11-0095 \\
-11-0101 \\
-11-0114 \\
-11-0121\end{array}$ & $\begin{array}{l}03.02 \\
05.08 \\
06.63\end{array}$ & $\begin{array}{l}25.9 \\
26.6\end{array}$ & $\begin{array}{r}.7 \\
5.6 \\
6.3 \\
7.7\end{array}$ & $\begin{array}{l}0.0900 \\
0.0900 \\
0.0898 \\
0.0891\end{array}$ & $\begin{array}{r}98.93 \\
100.60 \\
102.14 \\
104.81\end{array}$ & $\begin{array}{r}5.22 \\
.10 \\
.85\end{array}$ & $\begin{array}{l}7.6 \\
5.2 \\
3.0\end{array}$ & $\begin{array}{l}6 . \\
2 .\end{array}$ & & 19 & & & $\begin{array}{l}5 . \\
9 .\end{array}$ & & & 1 & \\
\hline $\begin{array}{l}-11-0137 \\
-11-0147 \\
-11-015 x\end{array}$ & 98 & $\begin{array}{l}25 . \\
26 . \\
28 .\end{array}$ & $\begin{array}{r}0.9 \\
6.5\end{array}$ & $\begin{array}{l}5 \\
10 \\
34 \\
3\end{array}$ & $\begin{array}{l}.46 \\
.05 \\
.38 \\
.23\end{array}$ & a & $\begin{array}{l}7.6 \\
5.2 \\
3.0\end{array}$ & 6. & & $\begin{array}{l}0 \\
8 \\
7 \\
8\end{array}$ & & & & : & & $-n$ & \\
\hline $\begin{array}{l}-11-017 \\
-11-0184 \\
-11-0194 \\
-11-0201\end{array}$ & $\operatorname{lng} 29$ & $\begin{array}{l}24.6 \\
25.7 \\
26.6 \\
27.7\end{array}$ & $\begin{array}{l}24.3 \\
25.6 \\
26.5 \\
28.6\end{array}$ & $\begin{array}{l}1146 \\
1144 \\
1137 \\
1134\end{array}$ & $\begin{array}{r}99.21 \\
101.47 \\
103.52 \\
107.48\end{array}$ & $\begin{array}{l}2.99 \\
2.64\end{array}$ & $\begin{array}{r}22.0 \\
7.6 \\
5.2 \\
3.0\end{array}$ & $\begin{array}{l}6.1 \\
4 . \\
2 .\end{array}$ & & $\begin{array}{l}3 \\
8 \\
7 \\
6\end{array}$ & & & & & & $\begin{array}{r}-1 \\
2\end{array}$ & \\
\hline $\begin{array}{l}-11 \\
-11 \\
-11 \\
-11\end{array}$ & 98. & $\begin{array}{l}2 \\
2 \\
2\end{array}$ & 5.5 & $\begin{array}{l}4 \\
2 \\
6 \\
0\end{array}$ & & & $\begin{array}{l}7.6 \\
5.2 \\
3.0\end{array}$ & . & & & & & & & & 0 . & \\
\hline $\begin{array}{l}8-11-0 \\
2-11-0 \\
-11-0 \\
-11-0\end{array}$ & 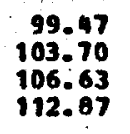 & 25.3 & $\begin{array}{l}3.2 \\
5.0 \\
6.3 \\
9.3\end{array}$ & $\begin{array}{l}1583 \\
1576 \\
1583 \\
1582\end{array}$ & $\begin{array}{r}96.96 \\
100.84 \\
103.65 \\
109.39\end{array}$ & $\begin{array}{l}4.86 \\
3.95\end{array}$ & $\begin{array}{r}22.0 \\
7.6 \\
5.2 \\
3.0\end{array}$ & $\begin{array}{l}6 . \\
2 .\end{array}$ & & & $\begin{array}{l}88 \\
8 \\
9 \\
9\end{array}$ & & & & & $\begin{array}{l}0 . \\
-0 .\end{array}$ & \\
\hline $\begin{array}{l}a-11-0292 \\
1-11-0302 \\
a-11-0312 \\
a-11-0322\end{array}$ & 20 & $\begin{array}{l}26.0 \\
29.2\end{array}$ & $\begin{array}{l}5.7 \\
9.2 \\
1.5\end{array}$ & 5 & 1 & 1 & $\begin{array}{r}22.0 \\
7.6 \\
5.2\end{array}$ & $\begin{array}{r}17.7 \\
6.1\end{array}$ & & $\begin{array}{l}9 \\
6 \\
2\end{array}$ & $\begin{array}{l}8 \\
8\end{array}$ & & & & & -1 & 27 \\
\hline $\begin{array}{l}8-11-033 x \\
8-11-0347 \\
-11-0352\end{array}$ & $\begin{array}{r}3.52 \\
4.52\end{array}$ & 2 & $\begin{array}{r}25.0 \\
25.4\end{array}$ & 0 & $\begin{array}{r}98 . \\
99 . \\
100 . \\
102 .\end{array}$ & 21 & $\begin{array}{r}22.0 \\
7.6 \\
5.2\end{array}$ & $\begin{array}{r}17.7 \\
6.1 \\
4.2\end{array}$ & 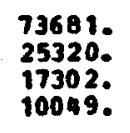 & $\begin{array}{l}5 \\
8 \\
7 \\
6\end{array}$ & $\begin{array}{l}0 \\
0\end{array}$ & & 3. & & & 6 & $\begin{array}{l}35 \\
26\end{array}$ \\
\hline $\begin{array}{l}1-11-0372 \\
1-11-0382 \\
-11-0392\end{array}$ & 104.54 & $\begin{array}{l}25.5 \\
25.9\end{array}$ & $\begin{array}{l}25.8 \\
25.8\end{array}$ & $\begin{array}{l}0.0 \\
0.0\end{array}$ & $\begin{array}{r}98 . \\
99 . \\
100 . \\
103 .\end{array}$ & $\begin{array}{l}48 . \\
47 . \\
46 .\end{array}$ & 5.2 & $\begin{array}{r}17.7 \\
6.1 \\
4.2\end{array}$ & : & $\begin{array}{l}99.59 \\
98.86 \\
98.59 \\
99.73\end{array}$ & $\begin{array}{l}99 \\
99 \\
99\end{array}$ & 32 & $\begin{array}{l}3: 74 \\
5.22\end{array}$ & & & 3.2 & $\begin{array}{l}605 . \\
30 . \\
360 .\end{array}$ \\
\hline
\end{tabular}


Table C.13. Expertmental thet for R-11 condenotmg on Tuba U

\begin{tabular}{|c|c|c|c|c|c|c|c|c|c|c|c|c|c|c|c|c|c|}
\hline Run No. & $\boldsymbol{T}_{\boldsymbol{V}}$ & $\underset{\text { (psia) }}{P}$ & Peat $_{\text {(ptia) }}$ & $\underset{(\mathrm{gPm})}{F_{c}}$ & $\begin{array}{c}T_{\boldsymbol{c}} \\
(\boldsymbol{P})\end{array}$ & $\left(1 b_{m} / g_{h}\right)$ & $\underset{(\mathbf{E P} m)}{\mathbf{F}_{\boldsymbol{w}}}$ & (ii/:) & Re & $T_{\text {win }}$ & $T_{\text {roon }}$ & ${ }_{P F i}$ & $\begin{array}{l}\Delta \mathbf{T r} \\
\mathbf{P F}\end{array}$ & $\begin{array}{c}Q_{c} \\
\text { (Bru/b) }\end{array}$ & $\begin{array}{c}Q_{w} \\
\left(B_{1} w / h\right)\end{array}$ & $\underset{\text { (\%) }}{\Delta}$ & 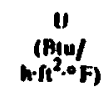 \\
\hline $\begin{array}{l}2-11-0010 \\
8-11-0020 \\
8-11-0030 \\
2-11-0040\end{array}$ & $\begin{array}{r}99.51 \\
101.95 \\
104.10 \\
107.89\end{array}$ & $\begin{array}{l}23.2 \\
24.3 \\
25.2 \\
27.0\end{array}$ & $\begin{array}{l}23.3 \\
24.3 \\
25.2 \\
26.9\end{array}$ & $\begin{array}{l}0.1334 \\
0.1312 \\
0.1312 \\
0.1313\end{array}$ & $\begin{array}{r}97.00 \\
98.56 \\
100.89 \\
104.14\end{array}$ & $\begin{array}{l}96.83 \\
95.07 \\
94.86 \\
94.65\end{array}$ & $\begin{array}{r}23.0 \\
7.6 \\
5.2 \\
3.0\end{array}$ & $\begin{array}{r}17.5 \\
5.8 \\
4.0 \\
2.3\end{array}$ & $\begin{array}{r}64186 . \\
21279 . \\
14644 . \\
0524 .\end{array}$ & $\begin{array}{l}84.25 \\
83.91 \\
83.98 \\
83.90\end{array}$ & $\begin{array}{l}84.92 \\
85.79 \\
86.70 \\
88.55\end{array}$ & $\begin{array}{l}0.64 \\
1.68 \\
2.71 \\
4.66\end{array}$ & $\begin{array}{l}14.93 \\
17.10 \\
18.76 \\
21.67\end{array}$ & $\begin{array}{l}7290 . \\
7136 . \\
7101 . \\
7052 .\end{array}$ & $\begin{array}{l}7355 . \\
7113 . \\
7043 . \\
6962 .\end{array}$ & $\begin{array}{r}-0.9 \\
0.3 \\
0.8 \\
1.3\end{array}$ & $\begin{array}{l}394 . \\
337 . \\
306 . \\
263 .\end{array}$ \\
\hline $\begin{array}{l}R-11-0050 \\
R-11-0060 \\
R-11-0070 \\
-11-0000\end{array}$ & $\begin{array}{l}100.38 \\
101.51 \\
102.38 \\
104.01\end{array}$ & $\begin{array}{l}23.6 \\
24.1 \\
24.5 \\
25.2\end{array}$ & $\begin{array}{l}23.6 \\
24.1 \\
24.5 \\
25.2\end{array}$ & $\begin{array}{l}0.0539 \\
0.0534 \\
0.0534 \\
0.0537\end{array}$ & $\begin{array}{l}95.48 \\
96.09 \\
96.61 \\
98.62\end{array}$ & $\begin{array}{r}39.15 \\
38.82 \\
38.80 \\
38.88\end{array}$ & $\begin{array}{r}23.0 \\
7.6 \\
5.2 \\
3.0\end{array}$ & $\begin{array}{r}17.5 \\
5.8 \\
1.0 \\
2.3\end{array}$ & $\begin{array}{r}73593 . \\
24356 . \\
16707 . \\
9682 .\end{array}$ & $\begin{array}{l}96.59 \\
96.49 \\
96.53 \\
96.57\end{array}$ & $\begin{array}{l}96.88 \\
97.26 \\
97.68 \\
98.45\end{array}$ & $\begin{array}{l}0.27 \\
0.78 \\
1.16 \\
1.91\end{array}$ & $\begin{array}{l}3.64 \\
4.64 \\
5.27 \\
6.50\end{array}$ & $\begin{array}{l}2944 . \\
2915 . \\
2911 . \\
2911 .\end{array}$ & $\begin{array}{l}3065 . \\
2937 . \\
3000 . \\
2855 .\end{array}$ & $\begin{array}{r}-4.1 \\
-0.7 \\
-3.1 \\
1.9\end{array}$ & $\begin{array}{l}653 . \\
508 . \\
446 . \\
362 .\end{array}$ \\
\hline $\begin{array}{l}R-11-0090 \\
R-11-0100 \\
R-11-0110 \\
R-11-0.120\end{array}$ & $\begin{array}{l}104.97 \\
109.47 \\
112.12 \\
118.75\end{array}$ & $\begin{array}{l}25.6 \\
27.4 \\
28.5 \\
31.8\end{array}$ & $\begin{array}{l}25.6 \\
27.6 \\
28.9 \\
32.3\end{array}$ & $\begin{array}{l}0.2011 \\
0.1990 \\
0.1988 \\
0.1997\end{array}$ & $\begin{array}{l}102.91 \\
106.89 \\
109.27 \\
115.49\end{array}$ & $\begin{array}{r}145.10 \\
143.03 \\
142.61 \\
142.37\end{array}$ & $\begin{array}{r}23.0 \\
7.6 \\
5.2 \\
3.0\end{array}$ & $\begin{array}{r}17.5 \\
5.8 \\
4.0 \\
2.3\end{array}$ & $\begin{array}{c}59001 . \\
19786 . \\
13614 . \\
8034 .\end{array}$ & $\begin{array}{l}77.27 \\
77.54 \\
77.36 \\
77.68\end{array}$ & $\begin{array}{l}78.25 \\
80.32 \\
61.37 \\
84.72\end{array}$ & $\begin{array}{l}0.96 \\
2.78 \\
3.98 \\
7.03\end{array}$ & $\begin{array}{l}27.21 \\
30.54 \\
32.75 \\
37.55\end{array}$ & $\begin{array}{l}10850 \\
10635 . \\
10568 \\
10460\end{array}$ & $\begin{array}{l}10993 . \\
10533 . \\
10333 . \\
10516\end{array}$ & $\begin{array}{r}-1.3 \\
1.0 \\
2.2 \\
-0.5\end{array}$ & $\begin{array}{l}322 . \\
281 . \\
261 . \\
225 .\end{array}$ \\
\hline $\begin{array}{l}8-11-0130 \\
8-11-0140 \\
8-11-0150 \\
8-11-0160\end{array}$ & $\begin{array}{c}100.79 \\
102.02 \\
103.00 \\
104.86\end{array}$ & $\begin{array}{l}23.7 \\
24.3 \\
24.7 \\
25.5\end{array}$ & $\begin{array}{l}23.8 \\
24.3 \\
24.7 \\
25.5\end{array}$ & $\begin{array}{l}0.0689 \\
0.0685 \\
0.0679 \\
0.0681\end{array}$ & $\begin{array}{r}96.16 \\
96.83 \\
97.92 \\
99.69\end{array}$ & $\begin{array}{r}50.07 \\
49.73 \\
49.21 \\
49.28\end{array}$ & $\begin{array}{r}23.0 \\
7.6 \\
5.2 \\
3.0\end{array}$ & $\begin{array}{r}17.5 \\
5.8 \\
4.0 \\
2.3\end{array}$ & $\begin{array}{c}72886 \\
24070 \\
16502 \\
9534\end{array}$ & $\begin{array}{l}95.54 \\
95.18 \\
95.13 \\
94.91\end{array}$ & $\begin{array}{l}95.89 \\
96.15 \\
96.56 \\
97.33\end{array}$ & $\begin{array}{l}0.33 \\
0.99 \\
1.45 \\
2.46\end{array}$ & $\begin{array}{l}5.07 \\
6.35 \\
7.16 \\
8.74\end{array}$ & $\begin{array}{l}3764 . \\
3732 . \\
3689 . \\
3686 .\end{array}$ & $\begin{array}{l}3781 . \\
3740 . \\
3758 . \\
3666 .\end{array}$ & $\begin{array}{r}-0.4 \\
-0.2 \\
-1.9 \\
0.5\end{array}$ & $\begin{array}{l}600 . \\
475 . \\
416 . \\
341 .\end{array}$ \\
\hline $\begin{array}{l}8-11-0170 \\
8-11-0180 \\
8-11-0190 \\
-11-0200\end{array}$ & $\begin{array}{r}99.41 \\
103.57 \\
106.19 \\
111.39\end{array}$ & $\begin{array}{l}23.2 \\
25.0 \\
26.2 \\
26.2\end{array}$ & $\begin{array}{l}23.2 \\
25.0 \\
26.1 \\
28.6\end{array}$ & $\begin{array}{l}0.1761 \\
0.1738 \\
0.1740 \\
0.1741\end{array}$ & $\begin{array}{r}97.57 \\
100.99 \\
103.22 \\
107.82\end{array}$ & $\begin{array}{l}127.68 \\
125.64 \\
125.53 \\
125.00\end{array}$ & $\begin{array}{r}23.0 \\
7.6 \\
5.2 \\
3.0\end{array}$ & $\begin{array}{r}17.5 \\
3.8 \\
4.0 \\
2.3\end{array}$ & $\begin{array}{c}58287 . \\
19535 . \\
13461 . \\
7892 .\end{array}$ & $\begin{array}{l}76.36 \\
76.66 \\
76.69 \\
76.77\end{array}$ & $\begin{array}{l}77.24 \\
79.17 \\
80.27 \\
82.76\end{array}$ & $\begin{array}{l}0.85 \\
2.50 \\
3.58 \\
5.98\end{array}$ & $\begin{array}{l}22.61 \\
25.65 \\
27.71 \\
31.62\end{array}$ & $\begin{array}{l}9614 . \\
9411 . \\
9373 . \\
9272 .\end{array}$ & $\begin{array}{l}9730 . \\
9483 . \\
9277 . \\
8952 .\end{array}$ & $\begin{array}{r}-1.2 \\
-0.8 \\
1.0 \\
3.5\end{array}$ & $\begin{array}{l}343 . \\
296 . \\
273 . \\
237 .\end{array}$ \\
\hline $\begin{array}{l}8-11-0210 \\
8-11-0220 \\
B-11-0230 \\
B-11-0240\end{array}$ & $\begin{array}{l}100.36 \\
102.06 \\
103.33 \\
106.16\end{array}$ & $\begin{array}{l}23.5 \\
24.2 \\
24.8 \\
26.0\end{array}$ & $\begin{array}{l}23.6 \\
24.3 \\
24.9 \\
26.1\end{array}$ & $\begin{array}{l}0.0893 \\
0.0891 \\
0.0889 \\
0.0891\end{array}$ & $\begin{array}{r}96.55 \\
97.82 \\
98.95 \\
101.45\end{array}$ & $\begin{array}{l}64.85 \\
64.62 \\
64.39 \\
64.35\end{array}$ & $\begin{array}{r}23.0 \\
7.6 \\
5.2 \\
3.0\end{array}$ & $\begin{array}{r}17.5 \\
5.8 \\
4.0 \\
2.3\end{array}$ & $\begin{array}{r}70371 . \\
23263 . \\
15949 . \\
9270 .\end{array}$ & $\begin{array}{l}92.36 \\
91.99 \\
91.87 \\
91.85\end{array}$ & $\begin{array}{l}92.82 \\
93.27 \\
93.74 \\
95.07\end{array}$ & $\begin{array}{l}0.44 \\
1.29 \\
1.87 \\
3.24\end{array}$ & $\begin{array}{r}7.77 \\
9.43 \\
10.52 \\
12.70\end{array}$ & $\begin{array}{l}4877 \\
4849 \\
4825 \\
4805\end{array}$ & $\begin{array}{l}5018 . \\
4876 . \\
4854 . \\
4840 .\end{array}$ & $\begin{array}{l}-2.9 \\
-0.5 \\
-0.6 \\
-0.7\end{array}$ & $\begin{array}{l}507 . \\
415 . \\
370 . \\
306 .\end{array}$ \\
\hline $\begin{array}{l}R-11-0250 \\
B-11-0260 \\
R-11-0270 \\
B-11-02 A 0\end{array}$ & $\begin{array}{c}100.46 \\
103.79 \\
106.14 \\
110.63\end{array}$ & $\begin{array}{l}23.6 \\
25.1 \\
26.1 \\
27.7\end{array}$ & $\begin{array}{l}23.6 \\
25.1 \\
26.1 \\
28.2\end{array}$ & $\begin{array}{l}0.1526 \\
0.1515 \\
0.1521 \\
0.1528\end{array}$ & $\begin{array}{r}98.19 \\
101.07 \\
103.26 \\
107.32\end{array}$ & $\begin{array}{c}110.59 \\
109.54 \\
109.72 \\
109.81\end{array}$ & $\begin{array}{r}23.0 \\
7.6 \\
5.2 \\
3.0\end{array}$ & $\begin{array}{r}17.5 \\
5.8 \\
4.0 \\
2.3\end{array}$ & $\begin{array}{l}62244 . \\
20714 . \\
14259 . \\
8326\end{array}$ & $\begin{array}{l}81.68 \\
81.55 \\
81.56 \\
81.49\end{array}$ & $\begin{array}{l}82.43 \\
83.71 \\
84.71 \\
86.76\end{array}$ & $\begin{array}{l}0.71 \\
2.16 \\
3.15 \\
5.27\end{array}$ & $\begin{array}{l}18.91 \\
21.16 \\
23.01 \\
26.51\end{array}$ & $\begin{array}{l}8316 . \\
8203 . \\
8192 . \\
8153 .\end{array}$ & $\begin{array}{l}8170 . \\
8175 . \\
8161 . \\
7883 .\end{array}$ & $\begin{array}{l}1.8 \\
0.4 \\
0.4 \\
3.3\end{array}$ & $\begin{array}{l}365 . \\
313 . \\
288 . \\
248 .\end{array}$ \\
\hline $\begin{array}{l}R-11-0290 \\
R-11-0300 \\
R-11-0310 \\
R-11-0320\end{array}$ & $\begin{array}{c}100.24 \\
102.46 \\
103.72 \\
106.51\end{array}$ & $\begin{array}{l}23.5 \\
24.4 \\
25.0 \\
26.2\end{array}$ & $\begin{array}{l}23.6 \\
24.5 \\
25.0 \\
26.3\end{array}$ & $\begin{array}{c}0.1116 \\
0.1108 \\
0.1116 \\
0.1105\end{array}$ & $\begin{array}{r}97.63 \\
99.39 \\
100.48 \\
102.91\end{array}$ & $\begin{array}{l}80.96 \\
80.22 \\
80.71 \\
79.77\end{array}$ & $\begin{array}{r}23.0 \\
7.6 \\
5.2 \\
3.0\end{array}$ & $\begin{array}{r}17.5 \\
5.8 \\
4.0\end{array}$ & $\begin{array}{l}67514 \\
22366 \\
15274 \\
8846\end{array}$ & $\begin{array}{l}88.71 \\
88.40 \\
87.88 \\
87.40\end{array}$ & $\begin{array}{l}99.26 \\
90.01 \\
90.20 \\
91.34 .\end{array}$ & $\begin{array}{l}0.52 \\
1.61 \\
2.32 \\
3.96\end{array}$ & $\begin{array}{r}11.25 \\
13.26 \\
14.68 \\
17.14\end{array}$ & $\begin{array}{l}6090 . \\
6017 . \\
6045 . \\
5953 .\end{array}$ & $\begin{array}{l}6003 . \\
6098 . \\
6014 . \\
5920 .\end{array}$ & $\begin{array}{r}1.4 \\
-1.4 \\
0.5 \\
0.6\end{array}$ & $\begin{array}{l}437 . \\
367 . \\
333 . \\
281 .\end{array}$ \\
\hline
\end{tabular}


Appendix D

SI CONVERSION FACTORS

An attempt has been made to present all key tables and figures in dual units (ACU and SI). The following conversion factors may be used to convert from ACU to SI units:

To convert from

To

Multiply by

Btu/h

W

0.2929

$B t u / h \cdot f t^{2}$

$W / m^{2}$

3.152

Btu/h $\cdot f t \cdot{ }^{\circ} \mathrm{F}$

$\mathrm{W} / \mathrm{m} \cdot \mathrm{R}$

1.730

$\mathrm{Btu} / \mathrm{h} \cdot \mathrm{ft} \mathrm{t}^{2} \cdot{ }^{\circ} \mathrm{F}$

$\mathrm{W} / \mathrm{m}^{2} \cdot \mathrm{R}$

5.675

Btu/ Ib

$\mathrm{J} / \mathrm{kg}$

$2.324 \times 10^{3}$

Btu/ $1 b_{m}{ }^{\circ} \mathrm{F}$

$\mathrm{J} / \mathrm{kg} \cdot \mathbf{K}$

$4.184 \times 10^{3}$

ft

m

0.3048

$f t^{2}$

$\mathrm{m}^{2}$

0.0929

$\mathrm{ft} / \mathrm{h}^{2}$

$\mathrm{m} / \mathrm{s}^{2}$

$2.35 \times 10^{-8}$

$\mathrm{ft} / \mathrm{s}$

$\mathrm{m} / \mathrm{s}$

0.3048

gpm

$\mathrm{m}^{3} / \mathrm{s}$

$6.309 \times 10^{-5}$

in.

cm

2.54

$1 b_{f} / f t$

$\mathrm{N} / \mathrm{m}$

14.59

$1 b_{m} / f^{3}$

$\mathrm{kg} / \mathrm{m}^{3}$

16.02

$1 b_{m} / h \cdot f t$

$\mathrm{Pa} \cdot \mathrm{s}$

$4.134 \times 10^{-4}$

$1 b_{m} / h \cdot \mathrm{ft}^{2}$

$\mathrm{Pa} \cdot s / m$

$1.356 \times 10^{-3}$

psia

$\mathrm{Pa}$

$6.895 \times 10^{3}$

$\Delta\left({ }^{\circ} E\right)$

$\Delta(\mathrm{K})$ or $\Delta\left({ }^{\circ} \mathrm{C}\right)$

0.5556

$$
\begin{aligned}
\text { Temperature conversion: } T(K)=5 / 9 \times\left[T\left(^{\circ} \mathrm{F}\right)-32\right]+273.15 \\
T\left({ }^{\circ} \mathrm{C}\right)=5 / 9 \times\left[\mathrm{T}\left({ }^{\circ} \mathrm{F}\right)-32\right]
\end{aligned}
$$


$\mathcal{U}$

$=$

$F$

. de

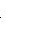


ORNL/TM-7797

Dist. Category UC-66d

\section{Internal Distribution}

1. H. G. Arnold
2. F. C. Chen
3. N. C. J. Chen
4. S. K. Combs
5-30. N. Domingo
31. M. D. Eden
32. D. M. Eissenberg
33. W. Fulkerson
34. A. Golshani
35. C. V. Hardin
36. J. E. Hardy
37. H. W. Hoffman
38. L. Jung
39. R. L. Linkous
40. G. H. Llewellyn
41. R. N. Lyon, Consultant
42. G. S. Mailen
43. R. N. McGill
44. J. W. Michel
45. R. W. Murphy
46. R. C. Robertson
47. T. W. Robinson, Jr.
48. M. P. Ternes
49. D. G. Thomas
50. H. E. Tramme11
51. ORNL Patent Office
52. Central Research Library
53. Document Reference Section
54-55. Laboratory Records Department
56. Laboratory Records (RC)

\section{Externa1 Distribution}

57. Dr. Win Aung, Division of Engineering, National Science Foundation, Washington, DC 20550

58. Professor Kenneth J. Bell, School of Chemical Engineering, Oklahoma State University, Stillwater, OR 74074

59. Professor A. E. Bergles, Department of Mechanical Engineering, Iowa State University, Ames, IA 50010

60. Ted Carnavos, Noranda Metal Industries, Prospect Drive, Newtown, CT 06470

61. Ronald L. Coit, Electric Power Research Institute, P.0. Box 10412, Palo Alto, CA 94303

62. J. B. Henderson, Wolverine Division, 2100 Market St, SE, P.O. Box 2202, Decatur, AL 35601

63. T. C. Hinrichs, Magma Power Company, 5143 Sunset Blvd,, Los Angeles, CA 92112

64. Ivonne J. Ingvarsson, Aerojet Nuclear Company, 550 Second Street, Idaho Falls, ID 83401

65. E. G. Keshock, Aerospace and Mechanical Engineering Department, University of Tennessee, Knoxville, TN 37916

66. G. A. Kolstad, Office of Energy Research, DOE, Washington, DC 20545

67. Raymond Kornbau, David Taylor Naval Ship Research and Development Center, Annapolis, MD 21402

68. J. T. Kuwada, Rogers Engineering Company, Inc, 111 Pine Street, Sixth Floor, San Francisco, CA 94111

69. Alan D. K. Laird, Mechanical Engineering Department, University of California, Lawrence Berkeley Laboratory, Berkeley, CA 94720

70. Raymond J. LaSala, Hydrothermal Support Branch, Division of Geothermal Energy, DOE, 12th and Pennsylvania Ave., NW, RA-342.3, 
71. G. W. Leonard, $\operatorname{ATDD}(P \& E)$ EPDD, Department of the Navy, China Lake, CA 93555

72. A. Lundberg, L-505, Dniversity of California, Lawrence Livermore Laboratory, P.0. Box 808, Livermore, CA 94550

73. Dr. Paul Marto, Naval Postgraduate School, Monterey, CA 93940

74. W. C. Moore, York Division, Borg Warner Corporatin, York, PA 17403

75. F. Mueller, Patterson-Relley Company, P.0. Box 458, East Stroudsburg; PA 18301

76. Revin P. Murphy, Specialty Chemicals Division, Allied Chemical Corporation, P.0. Box 1069, Buffalo, NY 14240

77. Kenneth E. Nichols, Barber-Nichols Engineering Company, Arvada, Co 80002

78. James Nugent, Geothermal Energy, San Diego Gas and Electric Company, P.0. Box 1831, San Diego, CA 92112

79. Dr.W. L. Owens, Lockheed Missiles and Space Company, Inc., P.0. Box 504, Sunnyvale, CA 95088

80. Robert W. Perkins, Spiral Tubing Corporation, 533 John Downey Drive, New Britain, CT 06051

81. J. J. Perona, Chemical and Metallurgical Engineering Department, University of Tennessee, Knoxville, TN 37916

82. Dr. Thomas Rabas; Steam-Turbine Generator Technical Opertions Division, Westinghouse Electric Corporation, Lester Branch, P.0. Box 9175 N2, Philadelphia, PA 19113

83. Kenneth F. Read, 448 Ferry Point Road, Annapolis, MD 21403

84. Professor Warren Rohsenow, Mechanical Engineering Department, Massachusetts Institute of Technology, 77 Massachusetts Avenue, Cambridge, MA 02139

85. Dr. R. R. Rothfus, Chemical Engineering Department, CarnegieMellon University, Schenley Park, Pittsburgh, PA 15213

86. John D. Ryan, Technology Consumer Products Branch, DOE, Forrestal Building, MS 6H-068, Washington, DC 20585

87. Dr. W. H. Thielbahr, DOE, Idaho Operations Office, 550 Second Street, Idaho Fal1s, ID 83401

88. Professor Ralph Webb, Department of Mechanical Engineering, The Pennoylvania State University, 208 Mechanical Engineering Building, University Park, PA 16802

89. J. F. Whitbeck, Idaho National Engineering Laboratory, Idaho Fal18, ID 83415

90. Mr. G. Wildsmith, Research and Development, Yorkshire Imperial Meta18, Ltd., P.0. Box 166, Leeds LSI IRD England

91. M. W. Urbanek, DSS Engineers, Inc., 7483 Northwest 4th Street, Fort Lauderdale, FL 33317

92. Mr. Jack S. Yampolsky, General Atomic Company, P.0. Box 81608, San Diego, CA 92138

93. Office of Assistant Manager for Energy Research and Development, Department of Energy, ORO, Oak Ridge, TN 37830

94-530. Given distribution as shown in DOE/TIC-4500 under category UC-66d (GE-Utilization Technology) 


\section{$\checkmark$}




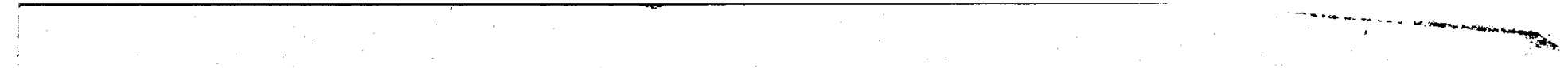

s.

क्ष

.

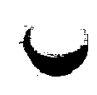

-

更

.

$\omega$ 